Universidade de Brasília

Faculdade de Educação Física

Programa de Pós-Graduação em Educação Física

Mestrado em Educação Física

\title{
A POLÍTICA NACIONAL DE PÓS-GRADUAÇÃO COMO EXPRESSÃO DA DECADÊNCIA IDEOLÓGICA: INCIDÊNCIAS NA EDUCAÇÃO FÍSICA
}

ANA PAULA DE MELO SILVA KIMURA 
ANA PAULA DE MELO SILVA KIMURA

\title{
A POLÍTICA NACIONAL DE PÓS-GRADUAÇÃO COMO EXPRESSÃO DA DECADÊNCIA IDEOLÓGICA: INCIDÊNCIAS NA EDUCAÇÃO FÍSICA
}

\begin{abstract}
Dissertação apresentada ao Programa de Pós-Graduação em Educação Física da Universidade de Brasília (UnB), na área de Estudos Sociais e Pedagógicos da Educação Física, Esporte e Lazer, vinculada à área de Atividade Física e Esporte, como requisito parcial à obtenção do título de mestre em Educação Física.
\end{abstract}

Orientador: Prof. Dr. Edson Marcelo Húngaro 


\section{A POLÍTICA NACIONAL DE PÓS-GRADUAÇÃO COMO EXPRESSÃO DA DECADÊNCIA IDEOLÓGICA: INCIDÊNCIAS NA EDUCAÇÃO FÍSICA}

\begin{abstract}
Dissertação apresentada ao Programa de Pós-Graduação em Educação Física da Universidade de Brasília (UnB), na área de Estudos Sociais e Pedagógicos da Educação Física, Esporte e Lazer, vinculada à área de Atividade Física e Esporte, como requisito parcial à obtenção do título de mestre em Educação Física.
\end{abstract}

Orientador: Prof. Dr. Edson Marcelo Húngaro

Defendida e aprovada em: 31/08/2016

\section{COMISSÃO EXAMINADORA}

Prof. Dr. Edson Marcelo Húngaro - Presidente Universidade de Brasília (UnB)

Prof. Dr. Pedro Fernando Avalone Athayde - Titular Universidade de Brasília (UnB)

Prof. Dr. Tadeu João Ribeiro Baptista - Titular

Universidade Federal de Goiás (UFG)

Prof. Dr. Fernando Mascarenhas Alves - Suplente Universidade de Brasília (UnB) 
Ficha catalográfica elaborada automaticamente, com os dados fornecidos pelo(a) autor(a)

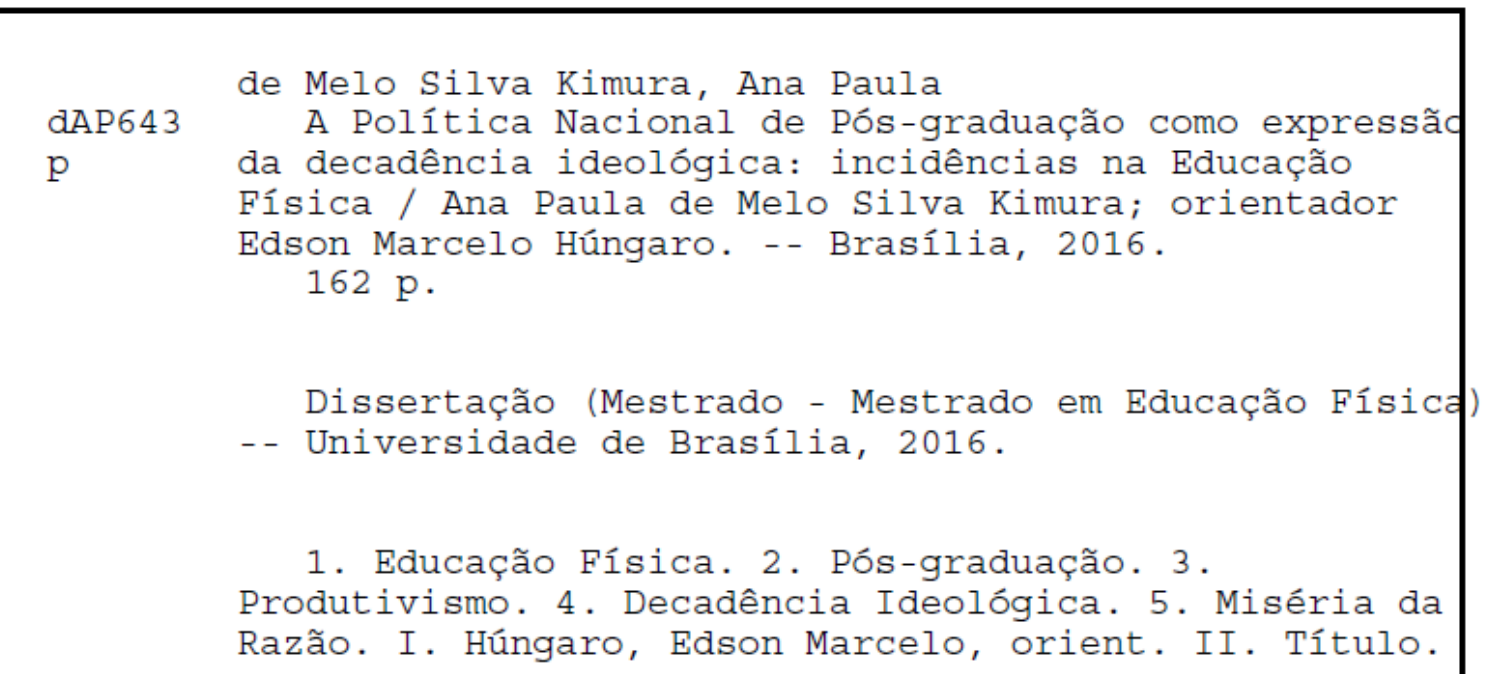


Aos meus pais, ao meu companheiro, a Coleguinha e a Carol. Essenciais na minha vida e nesse período de formação foram muito mais do que incentivadores, me fizeram acreditar em mim mesma.

Dedico. 


\section{AGRADECIMENTOS}

Reconhecendo alguma das minhas tantas contradições, a Deus e a Nossa Senhora agradeço...

Aos meus pais, pelo amor, carinho e dedicação, embora não entendendo ao certo o que era o mestrado, sempre contribuíram para a minha formação, enquanto 'SER' humano. Às minhas irmãs, Ana Flávia e Ana Carolina, ao meu irmão, Anderson Júnio, aos tios e primos pelo carinho a mim concedido.

A Maria Kimura e Akio Kimura pelo imensurável apoio.

Ao meu companheiro, Rafael Koiti, por gentilezas admiráveis, dedico-lhe estes versos, Não chame o meu amor de Idolatria,

Nem de ídolo realce a quem eu amo,

$[\ldots]$

'Beleza, Bem, Verdade', eis o que exprimo;

'Beleza, Bem, Verdade, todo o acento;

$[\ldots]$

'Beleza, Bem, Verdade' sós, outrora;

Num mesmo ser vivem juntos agora.

Willian Shakespeare (Soneto CV)

Aqueles que chamo de amigos, mais a verdade é que os escolhi por família, sempre estão por perto, essenciais a minha constituição e me dedicam imensurável amor, Carolina, Mariana Medeiros, Ariane, Cleiton, Fernando, Tiago, Danielle, Sandra, Éder, Cinira (in memorian), Lia, Gisleide, Diellen, Eleen, Dayanna, Jefferson, Cleiton, Wanessa, Eduardo, Rosirene, Greiton, Danyllo, Tadeu, Mariana, Família Lopes e Pedro Paulo, Família Queiroz e Luiza, Família Marques e Família Martins.

Aos amigos que cativei no mestrado para a vida. Muitas foram às idas e vindas de Brasília, tristes ficariam meus dias se não fossem as novas amizades ao longo dos anos, minha eterna e sincera gratidão a Dennia, Edriane, Eldernan, Cláudia, Valleria, Oromar, Bárbara, Willian, Marisa e Natália.

Aos colegas da Escola Municipal Irmã Catarina Jardim Miranda, pelas incontáveis ajudas, de maneira especial aos meus alunos, às professoras da $1^{\circ}$ fase do fundamental, Rogério e Luciane.

A todos os professores da ESEFFEGO/UEG e FEFD que foram fundamentais no começo da minha caminhada acadêmica, em especial aos professores Paulo Ventura, Tadeu Baptista, Sarah Silva, Mariana Cunha, Jefferson Moreira, Sérgio Moura e Sissilia Vilarinho.

Aos funcionários da UnB, em especial às queridas Quélbia e Alba, pela presteza.

Aos camaradas do AVANTE, que muito contribuíram para minha formação acadêmica, por meio das análises, discussões, debates e contribuições para qualificação do projeto.

Ao meu orientador Edson Marcelo Húngaro, que mesmo com todas as minhas limitações e contradições não desacreditou e aceitou me orientar, orientações essas não só para o mestrado, mais para a vida.

Aos professores da banca pelas contribuições com a avaliação da dissertação. Muito Obrigada! 
"[...] mas por ver que o mundo é assim mesmo, que as mentiras são muitas e as verdades nenhumas, ou alguma, sim, deverá andar por aí, mas em mudança contínua, não só nos dá tempo para pensarmos nela enquanto verdade possível, como ainda teremos primeiro de averiguar se não se tratará de uma mentira provável". (A Caverna, José Saramago).

"Privatizaram sua vida, seu trabalho, sua hora de amar e seu direito de pensar. É da empresa privada o seu passo em frente, seu pão e seu salário. $E$ agora não contente querem privatizar o conhecimento, a sabedoria, o pensamento, que só à humanidade pertence”. (Privatizado, Bertold Brecht).

"A arma da crítica não pode, é claro, substituir a crítica da arma, o poder material tem que ser derrubado pelo poder material, mas a teoria também se torna força material quando se apodera das massas." (Crítica da Filosofia do Direito de Hegel, Karl Marx). 


\section{RESUMO}

Esta pesquisa procurou estudar as incidências da Decadência Ideológica no âmbito da PósGraduação em Educação Física. A ênfase recaiu sobre as reais expressões da decadência ideológica, principalmente no que se refere à miséria da razão. Objetivou-se inicialmente apresentar e entender o processo da Decadência Ideológica no contexto do capitalismo contemporâneo por meio de uma contextualização histórica acerca da constituição da classe burguesa, os desdobramentos imbricados nessa decadência a partir do irracionalismo e da miséria da razão, para além o falso consenso sobre a materialização do movimento da pósmodernidade. No segundo momento, foi estabelecida uma linha de compreensão de determinações e condicionamentos em torno do capitalismo contemporâneo e a expressão real da miséria da razão pontuando as circunstâncias mais gerais da política de pós-graduação brasileira. Os procedimentos metodológicos para realizar essa investigação científica foram baseados em uma pesquisa exploratória de caráter bibliográfico, delimitada pela análise documental dos ordenamentos políticos que se fundam e são legitimados no Plano Nacional de Pós-Graduação, VI PNPG 2011-2020. Ao direcionarmos para o contexto da pós-graduação em Educação Física utilizamos a documentação referente à Área 21. Os documentos de área que foram considerados na análise foram os seguintes triênios: 2001/2003; 2004/2006; 2007/2009; 2010/2012 e os relatórios de avaliação dos triênios 2007/2009 e 2010/2012. Ao analisarmos os documentos identificamos que a real expressão da miséria da razão se dá pela tecnocracia, burocratização e produtivismo. Portanto, é possível notar o quanto uma discussão acerca da Decadência Ideológica na Educação Física é necessária. A Educação Física precisa incorporar esta discussão em seu meio, vez que ela subsidia a reflexão de uma série de aspectos relativos à área, entre eles, por exemplo, os processos formativos e a produção do conhecimento. Sendo assim, não tivemos a pretensão de apresentar caminhos conclusivos, mais sim apresentar o debate, ficando abertas possibilidades outras de novas investigações.

Palavras-chave: Educação Física, Pós-graduação, Produtivismo, Decadência Ideológica, Miséria da Razão. 


\begin{abstract}
This research sought to study the effects of Ideological Decadence within the Graduate in Physical Education. The emphasis is on the actual expressions of ideological decadence, especially in regard to the misery of reason. The objective was to initially present and understand the Ideological Decadence process in the context of contemporary capitalism through an historical context about the constitution of the bourgeois class, the imbricated developments that decline from irrationality and misery of reason, beyond the false consensus on the materialization of the postmodern movement. The second time was the establishment of a line of understanding determinations and conditionings around the contemporary capitalism and the real expression misery of reason punctuating the more general circumstances of the Brazilian Graduate policy. The methodological procedures to carry out this scientific research was based on an exploratory research of bibliographic bounded by documentary analysis of policy frameworks that are based and are legitimated at the National Graduate Plan VI PGNP 2011-2020. When we direct to the context of post-graduate in Physical Education use the documentation for Area 21. The area of documents which were considered in the analysis were the following triennium: 2001/2003; 2004/2006; 2007/2009; $2010 / 2012$ and the evaluation reports of the triennium 2007/2009 and 2010/2012. In reviewing the documents identified that the real expression of the reason poverty is by technocracy, bureaucratization and productivism. Therefore, it is possible to see how a discussion of Ideological Decadence Physical Education is required. Physical education needs to incorporate this discussion in their midst, since it subsidizes the reflection of a number of aspects of the area, including, for example, the training processes and the production of knowledge. Thus, we had the intention to present conclusive way, but rather to present the debate, leaving other possibilities open new investigations.
\end{abstract}

Key-words: Physical Education, Postgraduate Studies, Productivism, Ideological Decadence, Misery of reason. 


\section{LISTA DE GRÁFICOS}

GRÁFICO 1 - NÚMERO DE DOCENTES E DE ARTIGOS PUBLICADOS POR ANO 138 GRÁFICO 2 - QUANTIDADE DE AUTORES POR ARTIGOS NA LINHA DE PESQUISA DA ÁREA BIODINÂMICA

GRÁFICO 3 - QUANTIDADE DE AUTORES POR ARTIGOS NA LINHA DE PESQUISA DA ÁREA SOCIOCULTURAL...................................................................141

GRÁFICO 4 - DISTRIBUIÇÃO DA PRODUÇÃO INTELECTUAL DE ARTIGOS.........142

GRÁFICO 5 - DISTRIBUIÇÃO DA PRODUÇÃO INTELECTUAL DE LIVROS (L4 a L1) E CAPÍTULOS (C4 a C1).

GRÁFICO 6 - MEDIANA DOS PONTOS DA PRODUÇÃO INTELECTUAL DOS PROGRAMAS DA ÁREA 21 NO TRIÊNIO 2010/2012

GRÁFICO 7 - MÉDIA DOS PONTOS DA PRODUÇÃO INTELECTUAL DOS PROGRAMAS DA ÁREA 21 NO TRIÊNIO 2010/2012...

GRÁFICO 8 - VARIAÇÃO ENTRE AS NOTAS EM RELAÇÃO AOS TRIÊNIOS ANTERIORES (2007 - 2010 E 2013). 


\section{LISTA DE TABELAS}

TABELA 1: TOTAL DE CURSOS DE PÓS-GRADUAÇÃO EM EDUCAÇÃO FÍSICA AVALIADOS POR TRIÊNIO.

TABELA 2 - TOTAL DE CURSOS DE PÓS-GRADUAÇÃO EM EDUCAÇÃO FÍSICA DE (M), (M/D) E (MP) AVALIADOS POR TRIÊNIO

TABELA 3 - TOTAL DE CURSOS DE PÓS-GRADUAÇÃO EM EDUCAÇÃO FÍSICA AVALIADOS POR TRIÊNIO E REGIÃO

TABELA 4 - TOTAL DE PROFESSORES CREDENCIADOS NA PÓS-GRADUAÇÃO EM EDUCAÇÃO FÍSICA POR TRIÊNIO 


\section{LISTA DE SIGLAS}

ANDES - Sindicato Nacional dos Docentes do Ensino Superior

BID - Banco Interamericano de Desenvolvimento

BIRD - Banco Internacional para Reconstrução e Desenvolvimento

BNDE - Banco Nacional de Desenvolvimento Econômico

BM - Banco Mundial

CAPES - Coordenadoria de Aperfeiçoamento de Pessoal de Nível Superior

CBCE - Colégio Brasileiro de Ciências do Esporte

CELAFISCS - Centro de Estudos do laboratório de Aptidão Física de São Caetano do Sul

CFE - Conselho Federal de Educação

CNE - Conselho Nacional de Educação

CNP - Conselho Nacional de Pesquisas

CNPG - Conselho Nacional de Pós-Graduação

CNPq - Conselho Nacional de Desenvolvimento Científico e Tecnológico

CONBRACE - Congresso Brasileiro de Ciências do Esporte

CONICE - Congresso Internacional de Ciências do Esporte

DAV - Diretoria de Avaliação

DINTER - Doutorado Interinstitucional

DED - Departamento de Educação Física e Desporto

EF - Educação Física

EPT - Esportes Para Todos

ESG - Escola Superior de Guerra

FAPs - Fundações de Amparo à Pesquisa

FINEP - Financiadora de Estudos e Projetos

FMI - Fundo Monetário Internacional

GCE - Grupo de Consultoria Externa

GTC - Grupo Técnico Consultivo

GRTU - Grupo de Trabalho da Reforma Universitária

IES - Instituições de Ensino Superior

ISEB - Instituto Superior de Estudos Brasileiros

LDBEN - Lei de Diretrizes e Bases da Educação Nacional

M - Mestrado

M/D - Mestrado e Doutorado

MP - Mestrado Profissional

MCTI - Ministério da Ciência, Tecnologia e Inovação

MEC - Ministério da Educação

MEDLINE - Medical Literature Analysis and Retrieval System Online

MINTER - Mestrado Interinstitucional

ONGs - Organizações não Governamentais

ONU - Organização das Nações Unidas

PADCT - Programa de Apoio para o Desenvolvimento Científico e Tecnológico

PCNs - Parâmetros Curriculares Nacionais

PICD - Programa Institucional de Capacitação de Docentes

PG - Pós-Graduação

PGE - Pós-Graduação em Educação

PGEF - Pós-Graduação em Educação Física

PND - Plano Nacional de Desenvolvimento

PNE - Plano Nacional de Educação 
PNPGs - Plano Nacional de Pós-Graduação

PPGE - Programa de Pós-Graduação em Educação

PPGEFs - Programas de Pós-Graduação em Educação Física

PROAP - Programa de Apoio a Pós-Graduação

PROCAD - Programa Nacional de Cooperação Acadêmica

PRODOUTORAL - Programa que Estimula o Planejamento da Formação Doutoral

RBCE - Revista Brasileira de Ciências do Esporte

SCIELO - Scientific Electronic Library Online

SBPC - Sociedade Brasileira para o Progresso da Ciência

SCOPUS - Open to Accelerate Science

SNDCT - Sistema Nacional de Desenvolvimento Científico e Tecnológico

SNPG - Sistema Nacional de Pós-Graduação

UCB - Universidade Católica de Brasília

UDESC - Universidade do Estado de Santa Catarina

UFMT - Universidade Federal do Mato Grosso

UFPEL Universidade Federal de Pelotas

UFRJ - Universidade Federal do Rio de Janeiro

UFSM - Universidade Federal de Santa Maria

UNINOVE - Universidade Nove de Julho

USP - Universidade de São Paulo

USAID - Agência Norte Americana para o Desenvolvimento Internacional 


\section{SUMÁRIO}

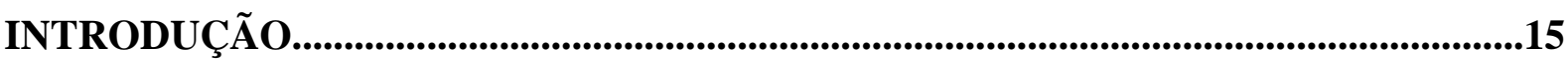

CAPÍTULO I - AS CIRCUNSTÂNCIAS DA DECADÊNCIA IDEOLÓGICA................26

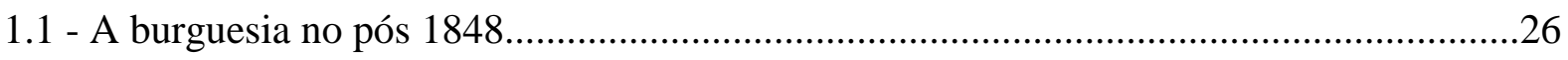

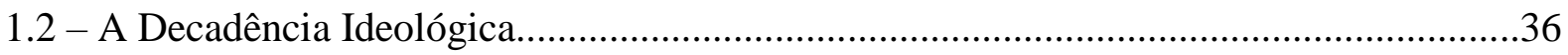

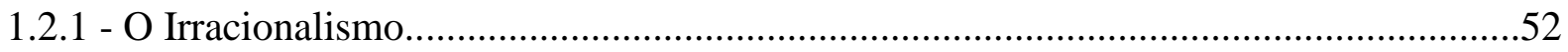

1.2.1.1 - O Falso Consenso Sobre a Materialização da Pós-modernidade...............................53

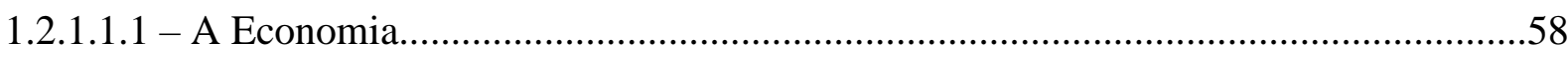

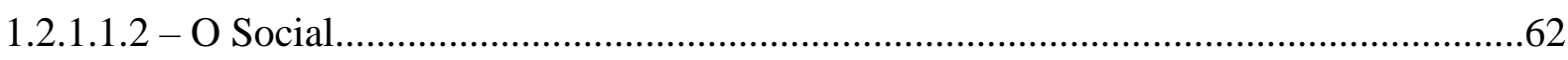

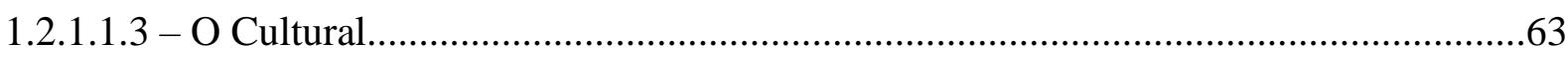

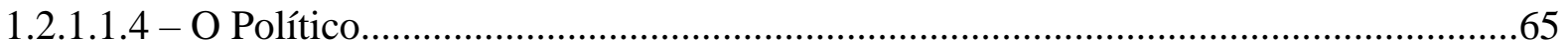

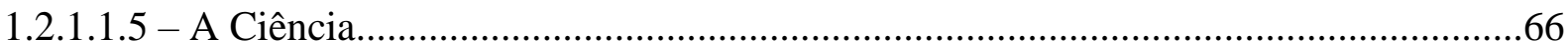

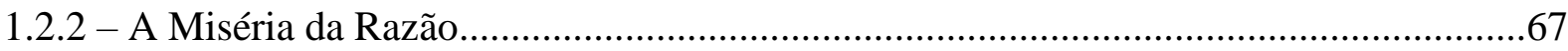

\section{CAPÍTULO II - O CONTEXTO E AS NUANCES DO PRODUTIVISMO ENQUANTO}

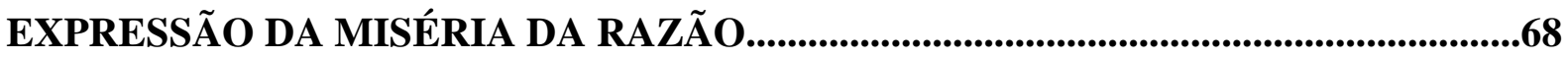

2.1 - A miséria da razão e o capitalismo contemporâneo..........................................................68

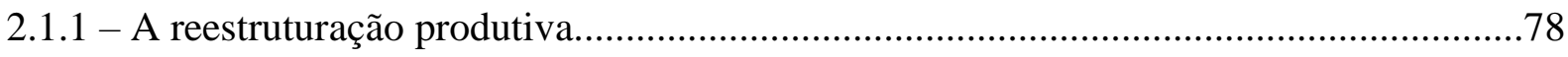

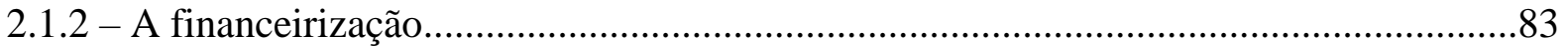

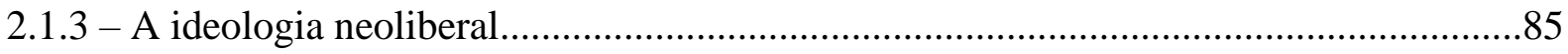

2.2 - Miséria da razão: expressão de um movimento real......................................................91

2.2.1 - A política de pós-graduação brasileira: determinações históricas e teóricas.................93

CAPÍTULO III - A PÓS-GRADUÇÃO EM EDUCAÇÃO FÍSICA................................114

3.1 - Pós-graduação em educação física: determinantes históricos.......................................114

3.2 - A educação física no quadro da pós-graduação brasileira............................................125

CAPÍTULO IV - CONSIDERAÇÕES FINAIS............................................................149

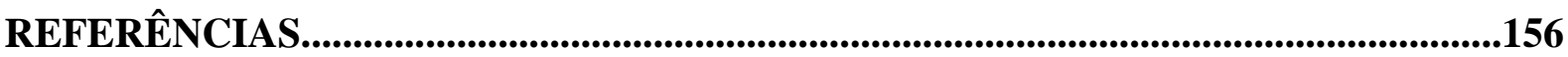




\section{INTRODUÇÃO}

[...] a educação física se constituiu na Europa, e seus traços fundamentais preparação de mão de obra para o trabalho industrial (garantir que o operário suporte fisicamente a jornada de trabalho industrial), consolidação e generalização da visão positivista de ciência (tanto a sociedade quanto os indivíduos serão sempre reduzidos a um organismo biológico) e controle de epidemias - foram mantidos durante o processo de sua expansão, com o domínio europeu, pelo mundo ${ }^{9}$ inclusive em sua inserção pelo Brasil. (HÚNGARO, 2010, p. 138).

A Educação Física surgiu a partir de um contexto de subserviência a classe burguesa, sendo seus ditames determinantes voltados para as características iniciais da área, estas com influências marcadas até hoje. Imersa a essas determinações da ordem capitalista, a Educação Física tendia a "formar" somente corpos. Não reconhecendo o gênero enquanto humano ao encarar os indivíduos sociais, tão logo, como meros reprodutores para a manutenção do capital. Inicialmente, isso se deu com o discurso higiênico e eugênico pendendo para o biologicismo ${ }^{1}$ e buscando dar forma a corpos saudáveis e fortes para o trabalho, contribuindo assim para a constituição da família burguesa.

É nesta perspectiva que podemos entender a Educação Física como a disciplina necessária a ser viabilizada em todas as instâncias, de todas as formas, em todos os espaços onde poderia ser efetivada essa construção deste homem novo: no campo, na fábrica, na família, na escola. A Educação Física será a própria expressão física da sociedade do capital. Ela encarna e expressa os gestos automatizados, disciplinados, e se faz protagonista de um corpo saudável; torna-se receita e remédio para curar os homens de sua letargia, indolência, preguiça, imoralidade, e, desse modo, passa a integrar o discurso médico, pedagógico... familiar. (SOARES, 2004, p. 6).

No Brasil, no século XIX, a reforma Couto Ferraz (1851) demonstrou preocupação com a prática de exercícios físicos. Em 1854, institui-se a ginástica ${ }^{2}$ (obrigatória no primário) e a dança (obrigatória no secundário). Já em 1882, Rui Barbosa, faz apontamentos sobre a importância da ginástica nas escolas normais, para ambos os sexos (DARIDO, 2003, p. 12).

\footnotetext{
${ }^{1}$ Conforme Lukács (2010, p. 88), [...] esta concepção "científica” da vida social, que via no homem um produto mecânico do ambiente e da hereditariedade, deixava fora da literatura, por causa do seu mecanicismo, precisamente os mais profundos conflitos da vida social. [...] A verdadeira figuração do homem é substituída pelo acúmulo quantitativo de detalhes superficiais. Em lugar dos grandiosos protestos contra os aspectos desumanos do desenvolvimento social, temos amplas figurações do que existe no homem de mais elementar e animalesco; em lugar da grandeza ou da debilidade do homem nos conflitos com a sociedade, temos amplas descrições de atrocidades exteriores. [...] " limitando, assim, a constituição do ser enquanto social.

${ }^{2}$ No final do século XIX e início do século XX, a educação física caracteriza-se como ginástica. Nestes anos foram apresentados como conteúdos os métodos ginásticos, alguns jogos e exercícios militares. Essa disciplina era de difícil sistematização devido à falta de professores e espaço para que as atividades ocorressem (CASTELLANI, 1991).
} 
Embora a Educação Física tivesse sido cunhada categoricamente como fundamental para o desenvolvimento da força e do corpo, a implantação das leis dada na capital federal (Rio de Janeiro) e nas escolas militares (DARIDO, 2003, p. 12) ocorreu em 1920 com a intensificação do processo de reforma educacional e a inserção da educação física nas escolas dos demais estados brasileiros.

A relevância direcionada para a formação do corpo pela ginástica estava intimamente relacionada ao corpo para o trabalho, militarizado e que correspondesse às demandas sociais impostas. Esse "homem novo necessário ao capital" (SOARES, 2004, p. 8), que foi estigmatizado e condicionado, passou a compor o cenário dessa nova sociedade consolidando os ideais da ciência positivista ${ }^{3}$.

No fim do século XIX e início do século XX, os métodos ginásticos tomam formato na Europa e são sistematizados, pois "[...] a ginástica a partir de então científica" (SOARES, 2004, p. 52) tinha singularidades. Como um todo, apontava para a purificação da raça e promoção da saúde. Os métodos que passaram a tangenciar o contexto da educação física e o militarismo são: o alemão, o sueco, o francês e o inglês.

Partindo da ideia e do objetivo de moldar uma moral cívica brasileira, o militarismo, principalmente na década de 1930, se apropria da educação física como viés de adestramento para a Segurança Nacional. "Pude assim dizer, estar a história da Educação Física no Brasil, se confundindo em muitos momentos com a dos militares" (CASTELLANI, 1991, p. 34). Mudanças conjunturais significativas (industrialização, urbanização e o estabelecimento de um Estado Novo - $1937^{4}$ ) incidiram diretamente na vida do trabalhador, manipulando seu

\footnotetext{
${ }^{3}$ Para o correto entendimento da constituição desse novo homem, é interessante apontar o que Alves (2015, p. 20-21) explica a respeito do panorama que determina esta constituição tendo como plano de fundo a apropriação que o capital faz do trabalho humano: [...] O fato é que a ideologia burguesa consegue entender a centralidade ontológica do trabalho e, estrategicamente, toma para si sua consolidação: a mediação de primeira ordem, pressuposto da relação entre o ser orgânico e a natureza, e sua particularidade de condicionar todas as demais mediações. Na medida em que a organização social capitalista se constitui sobre a base de uma complexa estrutura sociometabólica de produção e reprodução da vida, na qual a mediação mais importante é feita pelo capital, tal processo passa a determinar as formas de objetivação do ser social. Isso se desdobra no fato de se danificar o alcance de outro nível de interações que impulsionasse a humanidade a patamares superiores de sociabilidade, superando as relações mercantilizadas de viés capitalista. O que leva, consequentemente, à corrupção e alienação da essência antropológica do ser social e ao processo de inadequação ao gênero humano, colocando em xeque a real potencialidade das forças vitais da natureza humana. Tem-se a impossibilidade de se regular mediações indispensáveis para que possa haver a passagem de uma situação à outra e que novos processos sociais pudessem ser instaurados. Trata-se de uma processualidade histórica inerente às sociedades burguesas, caracterizada por modificações experimentadas pelo modo de produção, pelas relações sociais e pela própria subjetividade do ser social, o que gera graves influências às objetivações produzidas e, posteriormente, à generalidade humana.

${ }^{4}$ Foi um espaço temporal da história do Brasil também conhecido como a Era Vargas (1937-1945). Através de um golpe de estado, Vargas se apodera do poder e institui o Estado Novo afirmando que o objetivo constituía o reajuste político e a reorganização econômica do país. Por causa de características desse período, a Constituição de 1937 legitimou a censura à imprensa e a perseguição aos comunistas.
} 
tempo livre e os condicionando para a vida social burguesa na tentativa de aumento da capacidade de produção.

\begin{abstract}
Mas não somente a ela, produção, eram direcionadas as ações entabuladas. Pretendia-se mesmo, de forma articulada à preocupação com a produção, estabelecer um processo de educação da classe trabalhadora, pautada nos valores burgueses dominantes, de forma a descaracterizá-la enquanto classe social, diluindo os antagonismos de classe presentes na relação Capital-Trabalho. [...] à criação, pelo Decreto-lei $\mathrm{n}^{\circ} 4.408$, de 22 de janeiro de 42, do Serviço Nacional de Aprendizagem dos Industriários", posteriormente denominado "Serviço Nacional de Aprendizagem Industrial”, SENAI: “...Reconstitui-se-entre nós, mas de modo mais extenso e mais eficiente, do ponto de vista da riqueza e da cultura nacionais, o generoso, o humano, o belo sistema da medieval educação profissional em que o dono da indústria não era apenas o patrão do seu jovem empregado, mas também o seu educador..." (CASTELLANI, 1991, p. 95-96).
\end{abstract}

Com o fim do Estado Novo, surgem discussões sobre a necessidade de alterações na educação. Tais alterações foram direcionadas e legitimadas com fortes traços economicistas. A Lei de Diretrizes e Bases - 4.024/61 por mais que tratasse da educação nacional, não avançou no reconhecimento da emancipação dos seres sociais, todavia se restringiu a organização escolar, "[...] os verdadeiros problemas escolares permaneceram intocados e a educação popular sequer foi considerada" (CASTELLANI, 1993, p. 104). O reflexo liberalista na lei 4.024/61 transcorreu a legitimação da tendência tecnicista se tornando explícito nas leis 5.540/68 e 5.692/71. Essa compreensão de educação é refletida no cenário da educação física com o reforço de um caráter instrumental e da adoção de medidas para a adequação da educação ao modelo de desenvolvimento econômico.

\footnotetext{
A compreensão da Educação Física enquanto "matéria curricular" 117 incorporada aos currículos sob a forma de atividade - ação não expressiva de uma reflexão teórica, caracterizando-se, dessa forma, no "fazer pelo fazer" - explica e acaba por justificar sua presença na instituição escola, não como um campo do conhecimento dotado de um saber que lhe é próprio, específico - cuja apreensão por parte dos alunos refletiria parte essencial da formação integral dos mesmos, sem a qual, esta não se daria - mas sim enquanto mera experiência limitada em si mesma, destituída do exercício da sistematização e compreensão do conhecimento existente apenas empiricamente. Como tal, faz reforçar a percepção da Educação Física acoplada, mecanicamente, à "Educação do físico", pautada numa compreensão de saúde de índole bio-fisiológica, distante daquela observada pela Organização Mundial de Saúde, compreensão essa, sustentadora do preconceito no $\S 1 .^{\circ}$ do art. $3 .^{\circ}$ do Decreto n. ${ }^{\circ} 69.450 / 71$, que diz constituir a aptidão física, “...a referência fundamental para orientar o planejamento, controle e avaliação da Educação física, desportiva e recreativa, no nível dos estabelecimentos de ensino..." (CATELLANI, 1991, p. 108/109, Grifos do autor).
}

A aptidão física se tornou o foco. O esporte passou a dominar o momento histórico vez que este aponta e faz a seleção dos melhores, corroborando, portanto, para a lógica e 
manutenção do capital. O governo militar começa a investir na educação física em função das diretrizes $^{5}$, apoiando a circunstância ditatorial vigente, ao pautar o ensino na Integração Nacional e na Segurança Nacional na intenção de formação de um exército jovem e de desmobilização das forças políticas contrárias a forma de governo imposta, a resistência à ditadura.

Esse ambiente de "ditadura da burguesia fardada ${ }^{6}$ 1964-1985" toma o espaço esportivo com o intento de mostrar uma ideia deturpada do Esporte para Todos (EPT), movimento iniciado na década de 1970 objetivando moldar não só a educação física escolar, como também melhorar a aptidão física da população, incentivando a iniciativa privada a empreender no desporto de massa e camuflando a real situação política conservadora do Brasil. Exemplificando este conturbado período, tem-se a Copa do Mundo de 1970, megaevento divulgado pelo governo o qual utilizou do esporte espetáculo para camuflar o quadro de conservadorismo e autoritarismo político. Foram utilizados slogans ufanistas (Brasil ame-o ou deixe-o; Quem não vive para servir ao Brasil, não serve para viver no Brasil) para coibir e coagir aqueles que não acreditavam naquele modelo autoritário de governo.

Chegado o fim do "Milagre Brasileiro", aconteceu o processo de redemocratização e o reestabelecimento do movimento operário ${ }^{8}$, isto em função de mudanças que foram significativamente influentes para a reorganização da política e do cenário social brasileiro. Como exemplo, temos: o dossiê "Brasil Nunca Mais", o movimento pela anistia, o fim do bipartidarismo, o surgimento de instituições representativas da classe trabalhadora, o movimento das “Diretas Já”, entre outras (HÚNGARO, 2010, p. 136).

Deste modo, o início da década de 1980 apontou para um panorama diferenciado no Brasil e na Educação Física, direcionando para uma autocrítica e algumas saídas para repensar a hegemonia momentânea.

\footnotetext{
${ }^{5}$ Húngaro (2010, p. 138) afirma que, [...] vale ressaltar que mais uma funcionalidade foi assumida pela Educação Física no Brasil, durante o regime autoritário: a de contribuir com um processo de manipulação das consciências, ou seja: de contribuir com a "mentira".

${ }^{6}$ Segundo Húngaro $(2010$, p. 135) a denominação "ditadura da burguesia fardada" é mais adequado do que "ditadura militar", isso por dois fatores: $1^{\circ}$ os interesses da burguesia internacional financiaram o golpe militar em toda a América Latina e $2^{\circ}$ nem todos os militares foram condizentes e contribuíram com a tomada do poder;

${ }^{7}$ Período da "ditadura da burguesia fardada", por mais que estivessem acontecendo progressões econômicas, industriais e de infraestrutura, a inflação aumentava, a distribuição de renda praticamente inexistia aumentando a desigualdade social, significativo aumento da dívida externa, além de uma elevada repressão politica, tal repressão suprimiu até mesmo a constituição com a 'imposição' dos vários e punitivos Atos Constitucionais. $\mathrm{O}$ fim do "Milagre Brasileiro" não acontece de uma vez, mais gradativamente e a partir de movimentos opositores a forma de governo que estava instaurado.

${ }^{8}$ Húngaro (2010, p. 135) afirma que se trata da reorganização do movimento operário brasileiro que havia sido duramente reprimido - principalmente nos ataques aquela que, até então, tinha sido a agremiação política mais representativa desse movimento, o Partido Comunista Brasileiro/PCB.
} 
Tais circunstâncias, panoramicamente abordadas, incidiram na Educação Física e estimularam, nela, um teorizar crítico-sistemático (nunca antes visto) que trazia uma característica marcante: feito sob o ponto de vista "dos de baixo". Em outras palavras, a Educação Física, pela primeira vez, questiona teoricamente ${ }^{6}$ a sua histórica funcionalidade aos interesses das elites dominantes e inaugura um movimento de engajamento com a luta pela mudança radical (na raiz) da sociedade capitalista. (HÚNGARO, 2010, p. 136, Grifo do autor)

O primeiro autor a polemizar e analisar (corajosamente) o modo como a Educação Física estava instituída foi João Paulo Subirá Medina, em 1983, com o livro “A Educação Física cuida do corpo e...mente". Nele se encontra importantes questões para o começo do debate teórico na/da área, criticando a manipulação das consciências e orientando a pontualidade das leituras de $\operatorname{Marx}^{9}$ para a problematização da submissão da Educação Física para com o sistema.

\begin{abstract}
Diagnosticando a necessidade de uma crise para a Educação Física, Medina (1983) aponta e aborda uma riqueza de temas fundamentais para a discussão crítica da Educação Física, entre eles: o quadro da miséria das consciências; a essência do ato educativo e as relações da educação física com ele; o problema da fragmentação decorrente da crescente especialização das ciências - própria do positivismo; a denúncia da empobrecida formação do profissional da Educação Física; a crítica à enviesada compreensão da relação teoria e prática; um importante, embora inicial, mapeamento das concepções de Educação Física (convencional, modernizadora e revolucionária); a defesa de uma educação Física revolucionária e o chamamento para a necessidade de se construir uma nova Educação Física, comprometida com a utopia [...]. (HÚNGARO, 2010, p. 139).
\end{abstract}

Com a preocupação em torno da emancipação humana, um movimento revolucionário, progressista e renovador ganha força na Educação Física. Professores que haviam se retirado para o exterior a fim de dar continuidade em sua formação, retornam para o Brasil e incitam esse movimento dando contribuições bastante contundentes para a área, estas pertinentes até os dias mais atuais. A título de conhecimento, professores como Vitor Marinho de Oliveira, Celi Taffarel, Lino Castellani Filho, Valter Bracht, Apolônio Abadio do Carmo, Michele Escobar, Carmem Lúcia Soares, Mauri de Carvalho, Nivaldo Nogueira David, João Batista Freire (HÚNGARO, 2010, p. 140), entre outros, dão o ponta pé inicial a um projeto de "intenção de ruptura" ${ }^{10 "}$.

\footnotetext{
${ }^{9}$ Por mais que no livro não sejam encontradas citações diretas de Marx, encontramos algumas alusões; autores da tradição marxista como: Dermeval Saviani e Luiz Antonio Cunha; além de autores que apresentaram também interlocuções com Marx, como: Paulo Freire e Carlos Rodrigues Brandão (HÚNGARO, 2010).

${ }^{10}$ Húngaro (2010, p. 135) diz que A alusão, aqui, é a denominação atribuída, por José Paulo Netto, ao processo teórico-político instaurado pelo Serviço Social na luta contra sua funcionalidade original ao capital: nas suas origens, o Serviço Social se fundamentava na filantropia, protagonizada pela ação católica, que consistia (consiste) numa ação paliativa de combate à pobreza ao mesmo tempo em que despolitizava a luta pela
} 
O movimento renovador da Educação Física aborda a necessidade e importância da "realidade tender para a teoria ${ }^{11 "}$, expondo o reconhecimento e a interlocução com as Ciências Sociais, Filosofia e Antropologia. Não só a compreensão de novos conceitos estava surgindo como sendo também eles eram apresentados para a área, a saber: cultura corporal, corporalidade, dentre outros. Trazida ainda para o campo de reflexão da área foi a noção de ser social ${ }^{12}$, ser este que se constitui a partir de um projeto histórico. Este pressuposto se contrapõe ao impulso tendencioso de naturalização e biologização do ser humano e da vida material.

\begin{abstract}
Ignorar e negar a importância dos fundamentos ontológicos nos processos formativos é inviabilizar a assimilação do suporte teórico necessário para que o indivíduo assuma uma postura revolucionária em suas práticas sociais perante a sociabilidade capitalista. Ao mesmo tempo, é também danificar a instrumentalização da práxis educativa do professor para a promoção de uma intervenção mais consciente e transformadora na sua realidade, ampliando as mediações que ele possa arranjar em seu papel de formador de outras consciências. [...] A ciência possui importantes interferências a serem feitas, tanto no sentido de distinguir os delineamentos da formação em sua (s) concepção (ões) e limite (s) como também de operar mudanças estruturais e de conteúdo no processo formativo, focando os fundamentos ontológicos do ser social. É, pois, um fazer científico compromissado com o social e o político. (ALVES, 2015, p. 13).
\end{abstract}

Com as crises que o capitalismo estava passando desde a década de 1970, a humanidade se deparou com as transformações societárias, [...] nitidamente visualizadas na década de 1990 (HÚNGARO, 2010, p. 143). Elas afetaram os âmbitos econômico, social, político e cultural, incidindo na atmosfera Revolucionária da Modernidade e alterando o fazer

superação das relações sociais que a geravam. A produção acadêmica do Serviço Social, desde o final da década de 1960, vem criticando este caráter filantrópico - extremamente funcional ao capital, pois naturaliza a pobreza e a combate", tão-somente, em seus efeitos, com ações baseadas na solidariedade - e propondo que o Serviço Social seja alinhado com a superação da ordem burguesa. O rompimento com os interesses do capital e o engajamento na superação da ordem burguesa constituem a essência do processo de "intenção de ruptura.

${ }^{11}$ A Teoria Social de Marx possui como objeto de estudo a sociedade civil burguesa, isso a partir de uma visão ontológica de teoria. De acordo com Húngaro (2008), a teoria social é a "reprodução ideal do movimento real" da ordem burguesa e as determinações que constituem o modo de produção capitalista. Consequentemente, " $a$ teoria é subsídio para a ação revolucionária” (HÚNGARO, 2008, p. 22) caminhando, então, para além da interpretação. Crucial é entender para transformar, objetivando a superação do modo de produção capitalista.

${ }^{12}$ Segundo Alves (2015, pp. 14-15), [...] A formação do ser social e a ciência são mediaçôes essenciais para a materialização do processo de emancipação e devem estar empenhadas com a liberdade e a busca da felicidade dos seres humanos. Qualificar a formação dos indivíduos sociais e valorizar a aplicabilidade da ciência para com as necessidades estritamente humanas é resistir e abdicar do fato de que a lógica do capital e da propriedade privada seja a responsável pela história da humanidade, reafirmando o papel histórico que caberia ao proletariado e munindo-o com a "arma da crítica". [...] Nesse sentido da prática da ciência, Marx também ganha grande visibilidade ao construir uma teoria da história viabilizando o desenvolvimento da epistemologia moderna com a estruturação de um método mais avançado e legítimo de conhecimento. Para além da descoberta das intenções ideológicas das ideias hegemônicas, o processo de produção do conhecimento deve incidir no entendimento dos novos fenômenos complexos de múltiplas determinações produzidas na realidade objetiva. E isso só é possível por uma teoria crítica da história e da sociedade que seja capaz de explicar as leis gerais e as particularidades do tempo atual. Com sua concepção metodológica, Marx oferece recursos instrumentais para a revelação das contradições postas pela formação social burguesa. 
cientifico nas Ciências Humanas e Sociais, o que trouxe decorrências também para a Educação Física.

[...] entendemos que as circunstâncias históricas dos anos 90 (as determinações da realidade) foram extremamente avessas ao projeto de "intenção de ruptura" da Educação Física com seu passado conservador. Tal projeto, inaugurado nos anos 80 , fortalecido até meados dos anos 90 , começa a se defrontar com um contexto (da pósmodernidade) extremamente conservador (em certo sentido, inclusive, reacionário) e absolutamente avesso ao marxismo - que tanto inspirou o projeto de "intenção de ruptura". O diagnóstico de que se trata de uma conjuntura avessa ao marxismo não significa o "fim de Marx", mas tão somente, a constatação de que a realidade não tem tendido para a teoria. Em outras palavras, as circunstâncias não têm sido favoráveis às formulações marxianas (e marxistas) $)^{21}$. (HÚNGARO, 2010, p. 142, Grifos do autor).

O diagnóstico é sintomático: a década de 1990 abalou a Educação Física. Antes mesmo da solidificação do movimento renovador, suas referências passaram a ser questionadas e/ou criticadas. Foi assentada, então, uma crise de paradigmas disseminada pelo chamado movimento pós-moderno ${ }^{13}$, expressão esta da decadência ideológica burguesa.

A decadência ideológica ${ }^{14}$ burguesa se configura como uma espécie de mecanismo arranjado na formação social burguesa dentro do seu processo de desenvolvimento e consolidação. Mecanismo este que a partir da sua atuação histórica passa a ser percebido como determinante se sobrepondo a sua condição de derivação da instabilidade filosófica da burguesia quando ela transitava de classe revolucionária para conservadora, isto ficando mais evidente no pós 1848. Não obstante, a decadência ideológica deve ser vista como um fato histórico posto na reprodução da sociabilidade burguesa e identificado por Lukács com base nos fundamentos teóricos e ontológicos do arcabouço teórico marxiano, referencial bibliográfico que sustenta essa investigação.

Coutinho (2010) teoriza que a decadência ideológica se desdobra no irracionalismo e na miséria da razão ${ }^{15}$ de tal forma que ambas as manifestações acompanham a processualidade

\footnotetext{
${ }^{13}$ Conforme Húngaro (2008, p. 121), o termo movimento é utilizado, pois não há subsídios históricos que apontem para um novo processo civilizatório, portanto se não houve mudanças de tal ordem não podemos chamá-lo de pós-modernidade.

${ }^{14}$ Segundo Netto (2010, p. 243, Grifos do autor) “[...] a categoria de decadência ideológica - tão pouco compreendida e desprezada inclusive por pensadores do porte de um Sartre -, que Lukács extraiu de Marx já nos anos $1930 *^{34}$, e que está na base das concepções desenvolvidas pelo filósofo húngaro em A destruição da razão. Nesta obra ciclópica e polêmica, Lukács privilegia a contraposição entre razão e irrazão ${ }^{35}$ e demonstra que o moderno irracionalismo (cujos suportes são lançados por Schelling, mas cuja instauração cabe mesmo a Nietzche), terminando por abrir caminho ideológico para o horror nazista, fornece uma resposta evasionista em face da realidade histórico-social - e a evasão diante dos dilemas históricos-sociais mais decisivos é um traço peculiar ao pensamento decadente. [...]"

15 "A categoria de miséria da razão é uma elaboração pessoal de Carlos Nelson. Como se sabe, n'A destruição da razão, Lukács não opera suficientes discriminações ídeo-teóricas no campo da razão, de modo que permanece sem tratamento uma importantíssima vertente do pensamento ocidental moderno que, embora sendo
} 
do sistema capitalista em seus momentos de crise e de estabilidade. Surgem através do pensamento fetichizado e se desembocam estrategicamente no âmbito ideológico da vida social. Tanto o irracionalismo quanto a miséria da razão possuem características incapazes de explicarem de fato a totalidade do real havendo, porquanto, a negação das categorias do humanismo, da dialética e do historicismo. No irracionalismo ${ }^{16}$, há um ataque a ideia de totalidade, fragmentando os possíveis vieses de compreensão do real. Já a miséria da razão inviabiliza as possibilidades do vir a ser, ocasionando o empobrecimento da razão humana.

\begin{abstract}
Se analisássemos bem as constantes teóricas dos grupos dirigentes políticos, militares e econômicos de nosso tempo, descobriríamos que elas - consciente ou inconscientemente - são determinadas por métodos de pensamento neopositivista. Deriva disso a onipotência quase ilimitada desses métodos; e, quando o confronto com a realidade tiver conduzido à crise aberta, essa situação produzirá grandes abalos a partir da vida político-econômica até a filosofia no sentido mais amplo do termo. (LUKÁCS, 1978, p. 1-2).
\end{abstract}

formalmente racionalista, de fato capitula em face da realidade, aceitando a sua imediaticidade (isto é, a sua aparência reificada) e assumindo, como se fora implicação necessária do caráter relativo de todo conhecimento, um relativismo que redunda no agnosticismo social: trata-se das correntes positivistas e neopositivistas - nas quais o capitulacionismo em face da realidade quase sempre se assegura à base do epistemologismo ${ }^{36}$. As formulações de Carlos Nelson sobre a razão miserável, que, certamente, recuperam critica e seletivamente um largo legado intelectual - que arranca de Hegel (com a notável distinção, apresentada no prefácio à primeira edição da Ciência da Lógica, entre Verstand e Vernunft), passa pelos problemáticos Lukács e Korsch de 1923 e vem desaguar em alguns representantes da "escola de Frankfurt" $* 37$ e em pensadores influenciados diretamente por Marx, como Lefebvre e Goldmann) - tais formulações são inovadoras e criativas, esclarecendo sobretudo a relação de complementaridade entre racionalismo formal e irracionalismo moderno na cultura própria ao capitalismo do século 20 (ou, se se quiser, ao capitalismo dos monopólios em sua plena maturidade, que, para Carlos Nelson, configura o "capitalismo manipulatório"), cultura que é expressão inequívoca da decadência ideológica. Esta relação de complementaridade, Carlos Nelson descobre-a na função ideológica que moderno irracionalismo (a "destruição da razão") e racionalismo formal (a "razão miserável") desempenham como constitutivos da cultura burguesa no marco das tensões, oscilações e contradições da sociedade comandada pelo capital: entre a "angústia" e a "segurança", operam como constelações ídeo-teóricas sobre as quais se erguem "concepções de mundo" conservadoras/estabilizadoras da ordem." (NETTO, 2010, p. 244-245).

${ }^{16} \mathrm{O}$ irracionalismo é expresso a partir do movimento da pós-modernidade, sendo assim Rodrigues (2006, p. 26) nos apresenta as duas teses de Jameson sobre esse movimento; [...] a tese central de Jameson - a de que o pósmodernismo é a lógica cultural do capitalismo tardio - nos permite extrair duas conclusões. A primeira é que a cultura pós-moderna não equivale a nenhuma superação do capitalismo ou nascimento de uma sociedade pósindustrial. Jameson advertiu explicitamente que o pós-modernismo não deve ser entendido como a dominante cultural de uma ordem social inteiramente nova, mas apenas como reflexo de uma alteração sistêmica do próprio capitalismo. O capitalismo tardio - assevera o autor - permite mostrar o quanto o sistema capitalista após a Segunda Guerra se distingue do antigo imperialismo analisado por Lênin, mas também o quanto permanece sendo capitalismo (JAMESON, 1997: 22) ${ }^{10}$. A segunda conseqüência é que os traços típicos da forma mercadoria - sua fungibilidade, sua efemeridade e sua obsolescência programada - não dominam apenas a produção estética do último quartel do século XX, mas também a produção teórica, sobretudo, da área das ciências humanas e sociais. Jameson demonstra isto de duas maneiras bem precisas, embora sua análise tenha se voltado mais para avaliar as mutações operadas na arte contemporânea. Em Pós-modernismo: a lógica cultural do capitalismo tardio, ele afirma que tanto o "fim da arte" - criticado por Gullar - quanto a afirmação do "fim da ideologia" e do "fim das classes" - que despontam nas produções das ciências sociais a partir do fim da Segunda Guerra - podem ser entendidos como expressões pós-modernas. Além disso, Jameson sinaliza que uma análise retrospectiva do estruturalismo - que contém características muito similares as das expressões estéticas pós-modernas: uma espécie de surdez histórica e de refutação da noção moderna de progresso e de telos permite caracterizá-lo como uma subvariedade do pós-modernismo. 
Como observado por Lukács (1978), em seus diferentes complexos e mediações, o indivíduo social está susceptível a interferência do movimento da pós-modernidade. Perante isto, Patriarca (2012) demarcou a impactação da decadência ideológica em um importante domínio no mundo da Educação Física articulada aos seus processos históricos:

\begin{abstract}
Para além do estímulo ao irracionalismo pós-moderno que confrontou e mudou os rumos da Educação Física revolucionária dos anos 80 e 90, vivemos hoje o que Carlos Nelson Coutinho (2010) atribui à decadência ideológica da burguesia, que é o estímulo à "miséria da razão". Defendemos a ideia de que esse estímulo se dá por intermédio das políticas de avaliação da pós-graduação, que operam com instrumentos quantitativos de produção científica, não dando a devida atenção à qualidade das publicações. (PATRIARCA, 2012, p. 11).
\end{abstract}

Tomando como ponto de partida o pressuposto trazido por Patriarca (2012) acerca da relação do movimento da pós-modernidade e das políticas de avaliação da pós-graduação, foi que nos propusemos nessa dissertação a refletir como a decadência ideológica tem impactado a formação pós-graduada e a produção do conhecimento na Educação Física brasileira se atendo ao papel desempenhado pela Política Nacional de Pós Graduação (PNPG), o qual expressa um fluxo na direção da decadência ideológica, lógica cultural esta do capitalismo tardio. É, pois, uma tentativa de muitas outras de dar continuidade a estudos que venham de encontro com a tarefa de superação da sociabilidade do capital focando a prática social científica vez que o exercício da ciência na vida em sociedade é de fundamental importância uma vez que pode impulsionar ou não a condição do ser social para um estado de intensificação dos processos de alienação, degradação e inadequação ao gênero humano. Para tanto, as análises realizadas foram orientadas pela Teoria Social de Marx com a apropriação de discussões bem pontuais de Lukács, como foi destacado anteriormente.

[...] se em Marx encontra-se o núcleo ontológico e categorial para uma crítica da
sociedade burguesa, faz-se necessário buscar desenvolvimentos ulteriores na
tradição marxista ${ }^{2}$, tendo em vista apanhar determinações novas, numa condição de
existência na qual "tudo o que era [(é)] sólido e estável se dissolve no ar", como
caracterizaram Marx e Engels no seu Manifesto do Partido Comunista. Neste mesmo
texto, eles apontam que a burguesia não pode existir sem revolucionar
permanentemente os instrumentos de produção, as relações de produção e todas as
relações sociais (1998: 8). Então o desafio é entender o que muda no capitalismo
contemporâneo, o sentido das transformações econômicas e sociais em curso - a
condição geral da luta de classes - e as novas requisições para a intervenção do
estado. (BEHRING, 2008, p. 32).

Por conseguinte, o desafio apanhado pela pesquisa caminhou no sentido de ir além do indício mais aparente da realidade da pós-graduação que tem se estruturado a partir da ideia do "produtivismo" acadêmico, situação esta desenrolada na atual conjuntura do sistema 
capitalista. Ou seja, o imediatismo dessas circunstâncias se depara com indicativos contundentes da manipulação dos elementos do real para a articulação de tendências ideológicas que reafirmem o conformismo em torno da ordem vigente. O entendimento desta configuração social foi ferramenta fundamental para a compreensão do fazer científico na produção do conhecimento.

Os procedimentos metodológicos para realizar essa investigação científica foram baseados em uma pesquisa exploratória de caráter bibliográfico delimitada pela análise documental dos ordenamentos políticos que se fundam e são legitimados pelo/no Plano Nacional de Pós-Graduação de 2011 a 2020 e, mais especificamente ligado à Educação Física, a documentação referente à Área $21^{17}$ foram os triênios 2001/2003; 2004/2006; 2007/2009; 2010/2012 e os relatórios de avaliação dos triênios 2007/2009 e 2010/2012. Com estes documentos foi possível observar de maneira geral a Política Nacional de Pós-Graduação problematizando os parâmetros políticos que perpassam a produção do conhecimento haja visto o teor de determinação que este fator assume num programa de pós-graduação e, principalmente, ao trazer consequências significativas para a realidade específica da Educação Física.

Tendo, pois, registrado o objetivo desse estudo, os dois primeiros capítulos foram trilhados no sentido de inicialmente apresentar e entender o processo da decadência ideológica no contexto do capitalismo contemporâneo por meio de uma contextualização histórica acerca da constituição da classe burguesa, os desdobramentos imbricados nessa decadência a partir do irracionalismo e a miséria da razão (HÚNGARO, 2001; COUTINHO, 2010; LUKÁCS, 2010; PATRIARCA, 2012), e o falso consenso sobre a materialização da pós-modernidade (WOOD, 1999; DELLA FONTE, 2008; EVANGELISTA, 2008). No segundo momento, foi o estabelecimento de uma linha de compreensão de determinações e condicionamentos em torno do capitalismo contemporâneo e a expressão real da miséria da razão (MANDEL, 1982; BEHRING, 2008; ANTUNES, 2009; COUTINHO, 2010; NETTO, BRAZ, 2011) pontuando as circunstâncias mais gerais da política de pós-graduação brasileira (ÁVILA, 2008; PATRIARCA, 2012; SACARDO; 2012).

A seguir, o terceiro capítulo analisou os documentos citados dialogando com o referencial teórico construído para pontuar os vínculos com a decadência ideológica e as especificidades no contexto da Educação Física. Por fim, as considerações finais, nas quais

\footnotetext{
${ }^{17}$ A área 21 é formada por Programas de Pós-Graduação, sendo quatro as áreas (acadêmica e profissional) que a constituem: Educação Física; Fonoaudiologia; Terapia Ocupacional e Fisioterapia.
} 
foram tecidas as possíveis sínteses sugeridas pela análise e as implicações para a produção do conhecimento colaborando para o debate crítico sobre a respectiva temática. 


\section{CAPÍTULO I}

\section{AS CIRCUNSTÂNCIAS DA DECADÊNCIA IDEOLÓGICA}

O intuito deste capítulo é apresentar um debate teórico conceitual em torno da decadência ideológica, com foco na miséria da razão. Apresentando assim uma contextualização histórica sobre o desenvolvimento da burguesia e os desdobramentos imbricados na decadência ideológica (COUTINHO, 2010; LUKÁCS, 2010), que possui dois vieses: o irracionalismo e a miséria da razão (racionalismo formal), (COUTINHO, 2010; HÚNGARO, 2001; PATRIARCA, 2012; HÚNGARO, 2012), sendo que esta se desdobra no falso consenso sobre a materialização da pós-modernidade (DELLA FONTE, 2008; EVANGELISTA, 2008; WOOD, 1999).

\section{1 - A burguesia no pós $1848^{18}$}

As chamadas Revoluções Burguesas ${ }^{19}$ (iniciaram no século XVIII, se estendem pelo século XIX) dão um fim na servidão da idade média e o século XVIII é marcado pela tomada de poder por parte da burguesia (classe que possui significado econômico desde o século XIV) (HÚNGARO, 2001). No período de expansão comercial a aliança com rei foi de grande ajuda para os rompimentos com a igreja e senhores feudais ${ }^{20}$, já no século XVIII a monarquia

\footnotetext{
${ }^{18}$ Por que a burguesia no pós 1848 ? Na madrugada de 24 de fevereiro de 1848 , a revolução irrompeu em Paris - e, a partir daí, até o segundo semestre do ano seguinte, o continente estremeceu naquela que, segundo Claudín, foi a mais européia de todas as revoluções da Europa ${ }^{17}$ e que se saldou, em termos imediatos, pela derrota das forças democráticas e populares ${ }^{18}$. [...] O processo substantivo aqui em tela é a explicitação dos traços mais estruturais e peculiares da ordem burguesa - que estavam se objetivando, em todos os planos societários, da derrocada do Ancien Régime à década de quarenta. Com efeito, em nível histórico-universal, a primeira metade do século XIX constitui o espaço em que a dinâmica econômico-social posta em marcha pela burguesia heroica e empreendedora dos dois séculos anteriores configura a sociedade civil e o Estado segundo os seus particulares interesses de classe, apresentados como interesses gerais na luta contra as barreiras anticapitalistas herdadas e próprias da sociedade feudal. Trata-se do espaço histórico em que o desenvolvimento capitalista liquida ou subordina as instituições econômicas precedentes e engendra as suas próprias instituições sócio-políticas. Trata-se, em suma, do coroamento da constituição da ordem societária comandada pelo movimento do capital, redefinindo radicalmente as relações sociais e de classes. (NETTO, 1998, p. 5-6; Grifos do autor).

19 Segundo Húngaro (2001, p. 119-120) [...] Formam esse conjunto de revoluções a Revolução Americana (1776) e a Revolução Francesa (1789). Poderíamos juntar a elas a Revolução Inglesa (1640) realizada um século antes, mas que, de alguma maneira, influenciou-as. No contraponto desses processos sócio-políticos, encontravase o que se tornou conhecido como Revolução Industrial. [...] Esse ciclo revolucionário inaugurado em 1776 [...] só irá se encerrar em 1848, com a repressão aos movimentos revolucionários europeus que tiveram os pobres como seus protagonistas, na sua maioria trabalhadores ("A Primavera dos Povos").

${ }^{20}$ Segundo Netto e Braz (2011, p. 180) [...] como a crise do feudalismo resultou de múltiplos processos, desde os imediatamente ligados à atividade econômica àqueles derivados das lutas de classes. Na sequência, apontamos como o ciclo da Revolução Burguesa assentou em processos igualmente diferenciados, mas que convergiram no
} 
se torna um problema para a classe burguesa, sendo então este problema resolvido de maneira revolucionária, revoluções essas que ao fim deixou evidente o abandono das bandeiras progressistas por parte da burguesia, tornando evidente a sociedade de classes.

O renascimento ${ }^{21}$ e este movimento de transição do modo produção, do feudalismo para o capitalismo, da origem a Modernidade ${ }^{22}$. Esta tem por características dois momentos cruciais: o primeiro, em que a burguesia, na sua fase ascendente, apresentou um protagonismo revolucionário e progressista. O segundo momento (1830-1848) a burguesia, rompe com os ideais universais, dando início a sua fase decadente.

$\mathrm{Na}$ primeira fase da modernidade, a burguesia progressista, apresentava-se na tentativa de consolidação do novo modo econômico que pretendia a superação do feudalismo, neste momento a burguesia era representante de interesses universais, partindo de uma racionalidade humanista e dialética.

No período em que foi força revolucionária - do Renascimento até a sua consolidação como classe dominante -, a burguesia, através de seus pensadores, elaborou teorias revolucionárias e representativas de interesses universais, que tiveram o seu apogeu no chamado movimento da Ilustração. (HÚNGARO, 2001, p. 97).

O capitalismo, em sua origem, não só apresentou importância econômica e social, como também cultural, a filosofia burguesa, em sua fase ascendente, não limitava a realidade ao aparente, dessa maneira contribuiu diretamente para que as categorias progressistas, humanismo, historicismo concreto e razão dialética ${ }^{23}$, tomassem forma e contribuíssem adiante com a Teoria Social de $\operatorname{Marx}^{24}$.

surgimento de uma ordem social substantivamente diversa da do Antigo Regime - a ordem burguesa, construída pelo protagonismo revolucionário da burguesia e do bloco social que hegemonizou (o Terceiro Estado). (Grifos dos autores).

${ }^{21}$ Segundo Húngaro (2001, p. 130) Este, em geral, tem sido caracterizado como um movimento filosófico e cultural que, entre os séculos XV e XVI, recuperou os valores humanistas da Antiguidade clássica. Isso somente em parte é verdadeiro, já que o Renascimento foi muito mais que esse reviver da cultura clássica: ele foi, também, a expressão cultural, social e política de uma primeira tentativa de superação do feudalismo, superação esta objetivada pela nascente burguesia comercial.

${ }^{22}$ Húngaro (2001, p. 92) afirma que: O chamado Projeto da Modernidade, que teve o seu nascedouro no Renascimento, desenvolveu forças emancipatórias descomunais durante o Iluminismo, e teve como principal legatárior de suas potencialidades revolucionárias o movimento comunista - herdeiro dessas forças emancipatórias -, é duramente atacado pelos críticos pós-modernos como o principal responsável pelo momento que vivemos. É acusado de ser totalitário e determinista. Não há dúvida de que a Modernidade é correspondente ao período em que se tem a crise do feudalismo, a gênese do capitalismo e sua consolidação [...].

23 Compreendemos as categorias progressistas (humanismo, historicismo concreto, razão dialética) da fase progressista da burguesia a partir de Coutinho (2010, p. 28-29), este nos aponta cada uma das categorias da seguinte maneira: [...] o humanismo, a teoria de que o homem é um produto de sua própria atividade, de sua história coletiva; o historicismo concreto, ou seja, a afirmação do caráter ontologicamente histórico da realidade, com a consequente defesa do progresso e do melhoramento da espécie humana; e finalmente a razão dialética, em seu duplo aspecto, isto é, o de uma racionalidade objetiva imanente ao desenvolvimento da realidade (que se 


\begin{abstract}
$\mathrm{Na}$ época em que a burguesia era porta-voz do progresso social, seus representantes ideológicos podiam considerar a realidade como um todo racional, cujo conhecimento e consequente domínio eram uma possibilidade aberta à razão humana. [...] Esse caráter objetivamente progressista do capitalismo permitia aos pensadores que se colocavam do ângulo do novo a compreensão do real como síntese de possibilidade e realidade, como totalidade concreta em constante evolução. (COUTINHO, 2010, p. 22-25).
\end{abstract}

A expressão dessa totalidade concreta estava expressa na filosofia clássica, nesta época tivemos alguns autores que muito contribuíram como exemplo $\mathrm{Hegel}^{25}$; na economia política Smith e Ricardo e na crítica social Saint-Simon, Owen e Ricardo, estes fazem parte do 'movimento da herança ilustrada', herança essa que deixou um acervo teórico cultural singular, embora as limitações que esses autores apresentaram eram "inegável mérito de se basear sobre o reflexo de um ser social bem mais complexo e articulado [...] contudo, nos iluministas, a ação humana ainda era concebida de modo abstrato, individualista e idealista [...]” (COUTINHO, 2010, p. 25) sendo as análises voltadas para o esclarecimento espiritual, metafísico.

Porém a contribuição para a elaboração da Teoria Social é inegável, Marx tem como necessidade voltar às influências hegelianas para se apropriar, por um viés materialista, das questões de que os homens se autocriam na atividade produtiva consciente. Em relação aos

apresenta sob a forma da unidade dos contrários), e aquele das categorias capazes de apreender subjetivamente essa racionalidade objetiva, categorias estas que englobam, superando, as provenientes do "saber imediato" (intuição) e do "entendimento" (intelecto analítico).[...] A filosofia da época clássica era uma forma de conhecimento aberta para a elaboração de um saber verdadeiro, desantropomorfizador, científico, ainda que não estivesse inteiramente liberta de deformações ideológicas.

${ }^{24}$ O que é a Teoria Social? [...] Em termos breves e necessariamente bastante toscos, o resultado da inflexão promovida por Marx é uma teoria que enfoca a sociedade burguesa como produto extremamente complexo de um processo histórico plurissecular, no qual certas possibilidades do gênero humano não só se explicitam como, ainda, servem para iluminar etapas históricas precedentes ${ }^{36}$. Assim, mesmo tendo por objeto privilegiado a ordem burguesa, os resultados teóricos a que Marx chegou contêm determinações cujo âmbito de validez a transcendem, entre elas a concepção do homem como ser prático e social, produzindo-se a si mesmo através das suas objetivações (a práxis, de que o trabalho é exemplar) e organizando as suas relações com os outros homens e com a natureza conforme o nível de desenvolvimento dos meios pelos quais se mantém e se reproduz enquanto homem. O traço distintivo desta teoria é que ela toma a sociedade (burguesa) como uma totalidade concreta: não como um conjunto de partes que se integram funcionalmente, mas como um sistema dinâmico e contraditório de relações articuladas que se implicam e se explicam estruturalmente. Seu objetivo é reproduzir idealmente o movimento constitutivo da realidade (social), que se expressa sob formas econômicas, políticas e culturais, mas que extravasa todas elas. Por isso, a análise da organização da economia (a crítica da economia política) é o ponto de irradiação para a análise da estrutura de classes e da funcionalidade do poder (a crítica do Estado) e das formulações jurídico-políticas (a crítica da ideologia). (NETTO, 1998, p. 12; Grifos do autor)

${ }^{25}$ Segundo Lukács (2010, p. 51-83) Uma das questões fundamentais da preparação ideológica da Alemanha para a Revolução de 1848 é a tomada de posição em face da dissolução do hegelianismo. Esse processo de dissolução assinala o fim da última grande filosofia da sociedade burguesa. [...] a filosofia clássica alemã insistiu corretamente na contribuição dialética da subjetividade criadora, mesmo considerando sempre que esta subjetividade deve estar voltada para a reprodução da essência da realidade. A primeira teoria artística da decadência é a "ironia" do romantismo alemão, na qual esta subjetividade criadora já é absolutizada e a subjetividade da obra de arte degenera num jogo arbitrário com personagens criados do nada. 
economistas, Smith e Ricardo, ganharam ênfase no estudo de Marx pois, buscavam investigar

o funcionamento da sociedade burguesa, e descobriram que o trabalho é fonte de riqueza, e várias são as categorias determinantes para essa riqueza: capital, lucro, juro, classes, mercado, propriedade privada, entre outras, influenciando diretamente para a constituição da crítica marxiana $^{26}$. (HÚNGARO, 2008).

\begin{abstract}
A inflexão operada por Marx, repita-se, parte do trato crítico do acúmulo teóricocultural contido nas fontes. A centralidade do trabalho no processo de constituição da socialidade seria impensável sem a superação das determinações avançadas por Hegel na Fenomenologia do Espírito, assim como a categoria capital de práxis não seria elaborada se Marx não se detivesse nos desenvolvimentos neohegelianos (do materialismo de Feuerbach ao conjunto ideológico dos jovens hegelianos ${ }^{31}$ ); a própria reflexão política de Marx tem seu primeiro ponto de ataque nas duas primeiras críticas a Hegel, a de 1843 e a de 1844 (onde revolução e proletariado aparecem explicitamente tematizados $)^{32}$; e a descoberta da prioridade ontológica das determinações econômico-políticas na dinâmica sócio-histórica, deve-a Marx à sua análise dos clássicos da economia política, assim como os utópicos forneceram-lhe elementos para a crítica mordaz à ordem burguesa; principalmente, o seu exaustivo trabalho crítico (que se estendeu até o final dos anos cinqüenta) sobre o método filosófico de Hegel e seu sistema categorial permitiu-lhe estruturar uma obra sistemática, porém aberta. (NETTO, 1998, p. 10).
\end{abstract}

Posteriormente, a burguesia deixa de defender os interesses universais e progressistas, passando então a defender interesses próprios e a manutenção do capital, se tornando então classe dominante, rompendo com os ideais revolucionários dando origem ao "pensamento da ordem burguesa". Esse rompimento ${ }^{27}$ com a tradição progressista se torna evidente nas jornadas de fevereiro e março de 1848, tais movimentos representativos do estabelecimento da "ordem burguesa" (HÚNGARO, 2001, p. 122) contribuíram para ascensão da burguesia no poder.

[...] a sujeição da classe operária, que fizera as jornadas de fevereiro e março [de (1848)] (9), constituiu ao mesmo tempo a derrota dos seus adversários: na França os republicanos burgueses, e em todo o continente europeu as classes burguesas e camponesas em luta contra o absolutismo feudal; que a vitória da "República honesta" na França representou também a queda das nações que tinham respondido à revolução de Fevereiro com heróicas guerras de independência; que por fim a Europa com a derrota dos operários revolucionários, tinha recaído na sua antiga e

\footnotetext{
${ }^{26}$ Marxiano significa a obra constituída pelo próprio autor, marxistas, aqueles que se apropriam da obra do mesmo.

${ }^{27}$ Segundo Hobsbawm (1977, p. 33) "[...]1848 fracassou porque ficou evidenciado que a confrontação decisiva não era entre os velhos regimes e as "forças do progresso" unidas, mas entre "ordem" e "revolução social". Sua confrontação crucial não foi a de fevereiro em Paris, mas a de junho em Paris, quando os trabalhadores manobrados para uma insurreição isolada foram derrotados e massacrados. Eles lutaram e morreram bravamente. Cerca de 1500 caíram na luta das ruas - dois terços dos mortos do lado do governo. É característica da ferocidade do ódio que os ricos nutrem pelos pobres o fato de que uns 3 mil foram trucidados depois da derrota, enquanto outros 12 mil foram aprisionados, a maioria deportada para campos de trabalho na Argélia. Por seu turno, a revolução de fevereiro em Paris custara apenas 370 vidas."
} 
dupla escravidão, a escravidão anglo-russa. Os combates de Junho em Paris, a queda de Viena, a tragi-comédia de Berlim em Novembro de 1848, os esforços desesperados da Polônia, da Itália e da Hungria, a submissão da Irlanda pela fome tais foram os principais acontecimentos em que na Europa se concentrou a luta de classes entre burguesia e classe operária [...] (MARX, 1985, p. 15).

Estes movimentos se caracterizaram pela participação dos trabalhadores pobres (HOBSBAWM, 1977, p. 31), sinalizando assim como ficaria a configuração sócio-histórica posteriormente, tornando ainda mais evidente o protagonismo conservador da burguesia, direcionando para o "[...] abandono mais ou menos completo das conquistas do período anterior, algumas definitivas para a humanidade, como é o caso das categorias do humanismo, do historicismo e da razão dialética. ${ }^{28}$ " (COUTINHO, 2010, p. 21). Dessa maneira inicia-se a evidente contradição entre capital $x$ trabalho ${ }^{29}$, sendo então

[...] nas jornadas de 1848 que se patenteia o radical antagonismo entre ambos: quando se põe a exigência da república social, explicita-se o limite do mundo burguês. Até 1848, a frente social emancipadora parecia envolver o conjunto do terceiro estado; as barricadas de junho mostraram que as clivagens rompiam definitivamente esse bloco, mostraram que o povo, entificado unitária e identitariamente pela burguesia, era um compósito contraditório: as demandas populares tornavam-se incompatíveis com a direção de classe burguesa. 1848, numa palavra, explicita, em nível histórico-universal, a ruptura do bloco histórico que derruiu a ordem feudal: trouxe à consciência social o ineliminável antagonismo entre capital e trabalho, burguesia e proletariado. (NETTO, 1998, p. 6).

\footnotetext{
28 A categoria da razão dialética, segundo Húngaro (2001) não é patrimônio da burguesia, mais sim do pensamento revolucionário, o comunismo. O autor nos apresenta que: "A descontinuidade nas formulações filosóficas é, portanto, consequiência da descontinuidade do papel cumprido pela burguesia no processo histórico. Dessa análise feita por Carlos Nelson Coutinho, concordamos com quase todos os aspectos - não foi à toa que procedemos à recuperação histórica do processo de construção da chamada Modernidade, pois pretendíamos demonstrar a justeza da análise desse autor -, porém julgamos caberem duas ressalvas. A primeira delas diz respeito à inclusão da preocupação metodológica como um outro elemento representativo de progresso dentro dessa tradição ascendente da filosofia burguesa. Principalmente até 1848 , a preocupação com o método não configurou um reducionismo epistemologista, mas foi representativa da afirmação do racionalismo. A segunda delas refere-se à interpretação da razão dialética como algo que já tenha sido patrimônio da burguesia. Não nos parece que, mesmo em sua fase ascendente, a burguesia tenha feito uso da Razão Dialética. Aparentemente, esse núcleo categorial é um patrimônio do pensamento revolucionário comunista. Explicamos: mesmo tendo por origem Hegel, esse aspecto de sua filosofia foi justamente o divisor de águas entre a esquerda e a direita hegelianas. Em torno da formulação hegeliana "o que é racional é real, e o que é real é racional” é possível uma dupla interpretação. A primeira, extremamente conservadora, dá ênfase ao sistema de Hegel e interpreta que a realidade nada mais é que a consolidação da idéia, e mais, que a realidade como está concretizada é a realização da Razão; dessa forma justifica-se aquilo que está estabelecido. A outra, progressista, interpreta a mesma frase de outra forma, isto é, que a realidade pode ser racionalmente apreendida e a Razão humana se consubstancia no real, dando a este um constante movimento." (HÚNGARO, 2001, p. 185-186, grifos do autor).

${ }^{29}$ Segundo Netto e Braz (2011, p. 183) "Sob o capitalismo concorrencial surgem as lutas de classes na sua modalidade moderna, ou seja, as lutas fundadas na contradição entre capital e trabalho. Tais lutas, antagonizando a burguesia e os trabalhadores (elementarmente, a burguesia e o proletariado) e que, a partir daí, estarão sempre presentes na ulterior evolução do capitalismo, adquirem inicialmente formas grosseiras, mas, pouco a pouco, avançam para uma crescente politização, que as tornam mais conscientes - tal foi, na primeira metade do século XIX, o trânsito do ludismo ao catismo [...]. A violência dos primeiros protestos operários era a reação inevitável à brutalidade da exploração capitalista, então basicamente centrada no incremento do excedente mediante a extensão da jornada de trabalho (mais-valia-absoluta) - inexistiam quaisquer garantias para os trabalhadores, indefesos diante da rapacidade da burguesia. (Grifos dos autores).
} 
A burguesia ${ }^{30}$ assumiu definitivamente o papel de negação da elaboração da concepção de mundo rumo à emancipação humana, rompendo com os ideais do iluminismo, se tornando contrarrevolucionária, rompendo com interesses históricos universais, passando a denotar que a essência humana é somente a essência burguesa, resistindo às outras formas de sociabilidade, contendo os homens das suas condições históricas, tornando salutar de que estes tenham um fim em si mesmo.

\begin{abstract}
Em nível histórico-universal, a experiência de 1848 demonstrou os limites reais do projeto sócio-político conduzido pela burguesia - a liberdade deve restringir- se à liberdade de concorrer no mercado, a igualdade esgota-se na formalidade jurídica e a fraternidade se resolve na retórica e no moralismo. O projeto de emancipação humana, nestes limites, não desborda o terreno da emancipação política, tal como Marx mesmo o vislumbrou em 1844 (Marx, 1969). A partir desse marco, o protagonismo burguês centra-se na conservação da ordem (para a qual concorrem, necessariamente, programas reformistas, tornados especialmente claros depois de 1848) que se veio instaurando sobre as ruínas do Antigo Regime. A burguesia, enquanto classe, perde o interesse e a capacidade de fazer avançar a socialidade para além dos limites da lógica de acumulação e valorização do capital, em razão da qual se operou a emancipação política e se estabeleceu originalmente a figura do cidadão. $A$ dimensão essencial da emancipação humana só terá sentido para um outro sujeito histórico, cuja emersão primeira verifica-se em 1848: o proletariado. (NETTO, 1998, p. 6-7).
\end{abstract}

Com toda essa descontinuidade na evolução filosófica da burguesia, referente também ao desenvolvimento do capitalismo, a partir de 1848 as forças que antes contribuíam para o progresso têm se tornado "[...] fonte do aumento cada vez maior da alienação humana." (COUTINHO, 2010, p. 21).

O medo do movimento revolucionário de 1848 interrompe o ciclo progressista da burguesia e de suas possibilidades teóricas em dar respostas que expressem a visão de mundo ascendente do projeto burguês, pois sua perspectiva teórica choca-se com os limites do projeto de sociedade. Ou seja, entre a herança teórico-cultural emancipadora e a manutenção da ordem, a burguesia opta pelo segundo, dando origem ao "pensamento da ordem", berço perfeito para o nascimento das ciências sociais especializadas. (LARA, 2013, p. 93).

\footnotetext{
${ }^{30}$ Segundo Netto e Braz (2011, p. 183) "E a resposta burguesa ao protesto operário não se esgotou na repressão pura e simples; tomou também a forma de incorporação de novas ideologias à produção, de modo a atemorizar os proletários com a ameaça do desemprego pela redução da demanda de trabalho vivo. Na verdade, as inovações funcionam como uma arma nas lutas de classes; controladas pelos capitalistas, servem na guerra contra os trabalhadores - a propósito dos aperfeiçoamentos industriais ocorridos a partir da primeira crise capitalista, foi observado que, "desde 1825, quase todas as novas invenções resultaram das colisões entre o operário e o patrão, que, a qualquer preço, procura depreciar a especialidade do operário. Depois de cada nova greve de alguma importância, surgia uma nova máquina” (Marx, 1982a: 131). Como se vê, as lutas de classes influem fortemente no desenvolvimento das forças produtivas." (Grifos dos autores).
} 
Portanto, com a disseminação da alienação, os burgueses se tornaram detentores da matéria prima, dos instrumentos de trabalho e dos meios de vida, dessa maneira o produto passa a não pertencer a quem trabalha; aquele que contratou a força de trabalho é que conhece todo o processo, portanto o trabalhador não o compreende, desembocando na generalidade burguesa que passa a ser a negação do próprio homem.

\begin{abstract}
A burguesia tinha uma noção exata do fato de que todas as armas que forjara contra o feudalismo voltavam seu gume contra ela, que todos os meios de cultura que criara rebelavam-se contra sua própria civilização, que todos os deuses que inventara a tinham abandonado. Compreendia que todas as chamadas liberdades burguesas e órgãos e progresso atacavam e ameaçavam seu domínio de classe, e tinham, portanto, se convertido em "socialistas". (MARX, 2000, p. 82).
\end{abstract}

Mesmo consciente de que as armas que forjara contra o feudalismo se voltaria contra ela, insistiu e continuou a perpetuar a progressão de condições alienantes, essas se firmaram a partir de dois fatos: a) abandono da verdade para justificação teórica do existente, afim da sua perpetuação hegemônica; b) tentativa de limitar o papel da razão no conhecimento e na práxis dos seres humanos, pois como pensava Hegel, “[...] ser é processo” nessas condições a classe burguesa acaba por limitar as condições do "vir a ser" revolucionário (COUTINHO, 2010, p. 25).

\begin{abstract}
O significado de 1848 é precisamente este: com a derrota das aspirações democrático-populares, determinada pelo comportamento de classe da burguesia, o proletariado se investe, em nível histórico-universal, como o herdeiro das tradições libertárias e humanistas da cultura ocidental, constituindo-se como o sujeito de um novo processo emancipador, cuja condição prévia, histórico-concreta, é a ruptura mais completa com a ordem do capital. Assim, no plano prático-político, a revolução de 1848 tem um significado inequívoco: trouxe à cena sócio-política uma classe que, a partir daqueles confrontos, pode aceder à consciência dos seus interesses específicos — viabilizou a emergência de um projeto sócio-político autônomo, próprio, do proletariado; mais exatamente: propiciou a auto-percepção classista do proletariado; [...] o protagonismo que o proletariado praticamente assume a partir de 1848 está prefigurado/configurado teoricamente no Manifesto. Sob esta luz, portanto, a revolução de 1848 e o documento político fundante do projeto comunista são implicações necessárias da dinâmica mesma da ordem burguesa, no passo em que o proletariado se investe do estatuto de classe para si. (NETTO, 1998, p. 7-8; Grifo do autor).
\end{abstract}

Entende-se que este movimento evidenciou os antagonismos entre: capital x trabalho, burguesia x proletariado, que foram tomando proporções ideologizantes. Antes mesmo de todo esse processo ideologizante acontecer Marx e Engels apresentaram a "A Liga $a^{31}$ " um

\footnotetext{
${ }^{31}$ Partido que Marx e Engels militaram. Inicialmente conhecida como A Liga dos Justos, se aproximava da filosofia alemã e do socialismo francês, na segunda metade dos anos 40 algumas mudanças aconteceram, sendo essas estimulantes para o ingresso de Marx e Engels no partido, participando da I e II Congresso da Liga dos
} 
documento político fundamental ( $O$ Manifesto do Partido Comunista) para as bandeiras de luta que o proletariado estavam se apropriando, isso na tentativa do não abandono das categorias do humanismo e historicismo.

A classe antagônica, a que vende sua força de trabalho, correspondente ao proletariado, essa classe perpassa pelo fato da desintegrabilidade da efetivação do trabalho que não se materializa enquanto práxis. Em o Trabalho assalariado e capital $^{32}$, Marx (1985, p.16) aponta para três grandes divisões que estão diretamente relacionadas com a desintegrabilidade do trabalho: $1^{o}$ - as relações entre trabalho assalariado e capital, a escravidão do operário, o domínio do capitalista; $2^{o}$ - o desaparecimento inevitável das classes médias burguesas e do chamado campesinato no regime atual; $3^{o}-$ a sujeição comercial e a exploração das classes burguesas das diversas nações da Europa pelo tirano do mercado mundial, a Inglaterra.

Sendo assim o trabalho alienado em seu caráter subversivo captura as forças vitais do ser social, impedindo assim o desenvolvimento do gênero e impossibilitando a emancipação dos sujeitos. Viabiliza-se, neste contexto, o vislumbre pelo pensamento da ordem, rompendo com as condições de racionalidade humana afirmando o processo de decadência ideológica.

A partir dessa deturpação filosófica, ocasionada pela burguesia, o proletariado assume os interesses histórico-universais em sentido progressista. As substituições e negações das categorias fundamentais (humanismo, historicismo e razão dialética) que eram essenciais para compreensão do mundo são expressões que acompanham as contradições e antinomias presentes no capitalismo, distorcendo a realidade, sendo o mundo "compreendido" por uma razão manipulatória. Dessa maneira, a retomada dessas categorias faz parte do papel de arma da crítica do proletariado.

[...] Em lugar do humanismo, surge ou um individualismo exacerbado que nega a sociabilidade do homem, ou a afirmação de que o homem é uma "coisa", ambas as posições levando a uma negação do momento (relativamente) criador da práxis humana; em lugar do historicismo, surge uma pseudo-historicidade subjetivista e abstrata, ou uma apologia da positividade, ambas transformando a história real (o processo de surgimento do novo) em algo "superficial" ou irracional; em lugar da razão dialética, que afirma a cognoscibilidade da essência contraditória do real, vemos o nascimento de um irracionalismo fundado na intuição arbitrária, ou um profundo agnosticismo decorrente da limitação da racionalidade às suas formas puramente intelectivas. (COUTINHO, 2010, p. 30-31).

Comunistas, se tornando os responsáveis pela redação do documento do partido, que conheceríamos por Manifesto do Partido Comunista. Para aprofundamento sobre assunto consultar Netto (1998, p. 1-4).

${ }^{32}$ Nesta obra Marx analisa a real situação econômica da época (1849), dando condições para que o proletariado tivesse acesso e se apoderasse da arma da crítica alertando assim para o domínio da burguesia sobre a "escravidão" assalariada do proletariado. 
Desde cedo à burguesia percebeu a importância do conhecimento racional sobre a natureza o que lhe possibilitaria maior acúmulo de riquezas, e o que anteriormente era determinado pela fé, passa então a ser determinado pela razão (HÚNGARO, 2001, p. 132), razão esta em prol da manutenção do capital. Portanto, com as novas objetivações da vida cotidiana, o desenvolvimento da indústria e a intensa generalização da socialização do trabalho, propiciou a criação de um mercado mundial, que sob a base se edifica uma cultura universal, idealizando a ideia de igualdade e burocracia (COUTINHO, 2010, p. 33).

\begin{abstract}
O significado de 1848 é precisamente este: com a derrota das aspirações democrático-populares, determinada pelo comportamento de classe da burguesia, o proletariado se investe, em nível histórico-universal, como o herdeiro das tradições libertárias e humanistas da cultura ocidental, constituindo-se como o sujeito de um novo processo emancipador, cuja condição prévia, histórico-concreta, é a ruptura mais completa com a ordem do capital. Assim, no plano prático-político, a revolução de 1848 tem um significado inequívoco: trouxe à cena sócio-política uma classe que, a partir daqueles confrontos, pode aceder à consciência dos seus interesses específicos — viabilizou a emergência de um projeto sócio-político autônomo, próprio, do proletariado; mais exatamente: propiciou a auto-percepção classista do proletariado; (NETTO, 1998, p. 20).
\end{abstract}

Com a divisão capitalista do trabalho possibilidades de visualizar a unificação da humanidade, de compreensão da história universal " [...] permite elevar a conceito aquilo que antes só existia como virtualidade, ou seja, a realidade da humanidade como totalidade concreta de complexos teleológicos (fundados no trabalho e em suas objetivações), cujo movimento depende de leis racionais." (COUTINHO, 2010, p. 33).

\footnotetext{
No entanto, a burguesia - depois de consolidar a sua posição de classe dominante deixou de ser classe revolucionária e passou a estimular nos plano ídeo-cultural e político formulações que velam a compreensão da realidade social. Fê-lo assim para manter sua dominação. A este período, em que a burguesia se converte em classe conservadora, corresponde o que denominamos de período da "decadência ideológica" da burguesia. Tal período, também, constitui o que chamamos de Modernidade. (PATRIARCA, 2012, p. 19).
}

Deixando de ser classe revolucionária a imediaticidade da burguesia passa a ser o abandono da razão totalizadora, confundindo totalidade com totalitarismo, reforçando para o proletariado a necessidade da produção e do consumo, na tentativa de limitar e até mesmo negar a razão dialética, a concepção de mundo humanista e o historicismo concreto. Partindo desse contexto, o proletariado assume as bandeiras progressistas e revolucionárias, constituindo a intenção de emancipação evidenciando a contradição fundamental responsável pela luta de classes neste modo de produção vigente. 
Segundo Coutinho (2010, p. 29) "[...] o rompimento com a tradição progressista pode ser considerado, imediatamente, como um rompimento com o pensamento de Hegel. [...]”, pois o pensamento social no pós 1848 vai se adequando as circunstâncias históricas do capital, deixando para trás o caráter desantropomorfizador e científico da filosofia clássica, sendo assim, a burguesia

Ao tornar-se uma classe conservadora, interessada na perpetuação e na justificação teórica existente, a burguesia estreita cada vez mais a margem para uma apreensão objetiva global da realidade, a razão é encarada com um ceticismo cada vez maior, ou renegada como instrumento do conhecimento ou limitada a esferas progressivamente menores ou menos significativas da realidade. (COUTINHO, 2010, p. 22).

Nesse sentido a Teoria Social de Marx aponta para a necessidade dos sujeitos construírem sua própria vida, compreendendo que a consciência em relação à vida concreta é tardiamente determinada pelo ser social, tornando evidente a necessidade "da realidade tender para a teoria”. A relação entre o processo da vida material e a produção da consciência influi diretamente nos condicionantes filosóficos, contribuindo ou não para uma filosofia materialista, portanto,

[...] o produto tardio não é jamais necessariamente um produto de menor valor ontológico. Quando se diz que a consciência reflete a realidade e, sobre essa base, torna possível intervir nessa realidade para modificá-la, quer-se dizer que a consciência tem um poder real no plano do ser e não - como se supõe a partir das supracitadas versões irrealistas - que ela é carente de força.” (LUKÁCS, 1978, p. 2).

Percebe-se, portanto que houve uma orientação subjetivista dada ao conhecimento, sendo esta criticada por Marx, isso por contribuir para a limitação do entendimento das condições objetivas de vida, condicionando assim a própria consciência dos sujeitos, tornando evidentes as forças reacionárias dando lugar a Decadência Ideológica da burguesia.

Com a decadência do pensamento burguês e sua consolidação no poder, a preocupação dos intelectuais não mais é declarar a verdade e sim justificar o existente. Dessa maneira em certos momentos há uma estimulação do irracionalismo e noutros o empobrecimento da razão, sendo assim a

[...] A decadência ideológica surge quando as tendências da dinâmica objetiva da vida cessam de ser reconhecidas, ou são mesmo mais ou menos ignoradas, ao passo que se introduzem em seu lugar desejos subjetivos, vistos como força motriz da realidade. Precisamente porque o movimento histórico objetivo contradiz a ideologia burguesa, até mesmo a mais "radical" e "profunda" introdução de tais momentos 
puramente subjetivos transforma-se objetivamente num apoio à burguesia reacionária. (LUKÁCS, 2010, p. 93).

Para melhor compreensão dessa categoria desenvolvida por Lukács, tentaremos discorrer sobre seu processo histórico e características que até hoje influenciam o meio acadêmico. Compreendendo que a luta ideológica é intrínseca a sociedade de classes, a tentativa desse trabalho se da em apresentar a importância da tomada de consciência sobre os conflitos sociais, na tentativa de apresentar uma crítica social aliada à possibilidade de transformação social.

\title{
1.2 - A Decadência Ideológica
}

A decadência ideológica consiste nas contradições internas dessa sociedade, a sociedade burguesa, sendo assim o problema central da decadência esta em não compartilhar as deformidades sociais tais como são mais sim as deturpando, considerando (e muitas vezes desconsiderando até mesmo) somente o aparente, tornando as condições de deformações humanas naturais e normais, [...] A categoria decadência ideológica, [...], designa o estado espiritual da burguesia após 1848. [...] (LARA, 2013, p. 94). Para que haja mudanças são fundamentais lutas internas para um projeto de "intenção de ruptura ${ }^{33}$ ".

\begin{abstract}
A decadência ideológica denunciada por Marx e Engels e interpretada por Lukács ${ }^{3}$, é o período claramente marcado pela tentativa de os ideólogos burgueses produzirem conhecimentos que têm como premissa a evasão da realidade social, com explícitas intencionalidades de conservação da ordem do capital. Lukács analisa o desenvolvimento da apologética burguesa e a mistificação do pensamento social, demonstra a relação entre as distorções espirituais da ideologia contrarrevolucionária presente nas ciências do espírito e, por conseguinte, a evolução teórico-ideológica da sociedade capitalista como processo de amenização nas análises sociais que criticassem a ordem social dominante. (LARA, 2013, p. 92).
\end{abstract}

Lukács (2010) tece a crítica a alguns autores da ciência moderna, se tratando de Guizot, Lukács afirma que esse antes da Revolução de 1848 se apropria da função da luta de classes e posteriormente a Revolução omite o que sabe como forma de manutenção do

\footnotetext{
${ }^{33}$ Húngaro (2010, p. 135) afirma que “A alusão, aqui, é a denominação atribuída, por José Paulo Netto, ao processo teórico-político instaurado pelo Serviço Social na luta contra sua funcionalidade original ao capital: nas suas origens, o Serviço Social se fundamentava na filantropia, protagonizada pela ação católica, que consistia (consiste) numa ação paliativa de combate à pobreza ao mesmo tempo em que despolitizava a luta pela superação das relações sociais que a geravam. A produção acadêmica do Serviço Social, desde o final da década de 1960, vem criticando este caráter filantrópico - extremamente funcional ao capital, pois naturaliza a pobreza e a "combate", tão-somente, em seus efeitos, com ações baseadas na solidariedade - e propondo que o Serviço Social seja alinhado com a superação da ordem burguesa. O rompimento com os interesses do capital e o engajamento na superação da ordem burguesa constituem a essência do processo de "intenção de ruptura".
} 
governo em vigência sendo assim, esta forma deturpada de ciência toma forma e força, pois [...] O pensamento dos apologetas não é mais fecundado pelas contradições do desenvolvimento social, as quais ao contrário, ele busca mitigar, de acordo com as necessidades econômicas e políticas da burguesia (Ibidem, p. 52).

\begin{abstract}
Essa liquidação de todas as tentativas anteriormente realizadas pelos mais notáveis ideólogos burgueses no sentido de compreender as verdadeiras forças motrizes da sociedade, sem temor das contradições que pudessem ser esclarecidas; essa fuga numa pseudo-história construída a bel-prazer, interpretada superficialmente, deformada em sentido subjetivista e místico, é a tendência geral da decadência ideológica. [...] Metodologicamente essa mudança de orientação manifesta-se no fato de que [...] os teóricos evitam cada vez mais entrar em contato com a própria realidade, colocando no centro de suas considerações, ao contrário, as disputas formais e verbais com as doutrinas precedentes. (Ibidem, p. 53).
\end{abstract}

Dessa forma a decadência ideológica começa a impactar expressivamente a ciência moderna, evadindo-se da análise da realidade, afirmando que o aparente é o verdadeiro. $\mathrm{O}$ progresso passa a ser a contradição veemente no contexto da decadência, se tornando um problema do desenvolvimento da sociedade de classes, desembocando na unilateralização do conhecimento impossibilitando que o sujeito se reconheça enquanto histórico. Dessa maneira a Teoria Social ${ }^{34}$ de Marx é constituída para que possamos compreender a sociedade civil burguesa se preocupando "[...] com a totalidade da vida social, interessada em descobrir a verdade do mundo [...]" (LARA, 2013, p. 92), afirmando sobre a constituição do ser social e apresentando a totalidade do mundo - objeto da ontologia -, rompendo com a ideia de naturalização do real.

\begin{abstract}
Este naturalismo não é senão a aparência, e aparência puramente estética, das grandes e pequenas robinsonadas. Na realidade, trata-se antes de uma antecipação da "sociedade civil", que se preparava desde o século XVI e que no século XVIII marchava a passos de gigante para a maturidade. Nesta sociedade de livre concorrência, cada indivíduo aparece desligado dos laços naturais, etc., que, em épocas históricas anteriores, faziam dele parte integrante de um conglomerado humano determinado e circunscrito. Este indivíduo do século XVIII é produto, por um lado, da decomposição das formas de sociedade feudais, e por outro, das novas forças produtivas desenvolvidas a partir do século XVI. (MARX, 2016, p. 1);
\end{abstract}

\footnotetext{
${ }^{34}$ Se o suposto de que a Marx interessava a compreensão de um determinado objeto - a ordem burguesa - é verdadeiro (e estamos convencidos de sua correção), põe-se uma questão extremamente relevante: qual é a validade da teoria marxiana? Sobre essa, poderíamos tecer duas observações. A primeira observação é a de que a universalidade dessa obra está delimitada pela história, ou seja, enquanto a sociabilidade humana se der sob uma organização social em que o capital protagoniza a regência do trabalho as categorias de análise descobertas por Marx terão vigência. Isso significa que é impossível a compreensão do modo de produção capitalista sem a referência à obra de Marx. A segunda observação é a de que o potencial analítico das categorias por ele descobertas estará esgotado quando - e se - estiverem esgotadas as relações sociais de produção da ordem burguesa. Mas essa segunda observação não implica numa compreensão de que a obra marxiana não nos ofereça elementos para o entendimento de formações sociais precedentes e posteriores à ordem burguesa. (HÚNGARO, 2008, p. 23)
} 
Portanto, a sociedade burguesa percebe a importância da criação de teorias que justifiquem a acumulação capitalista, naturalizando a exploração das forças de trabalho, fragmentando e condicionando a realidade ao efêmero, sendo assim (MARX apud LUKÁCS, 2010, p. 56) "quanto mais alienada for a forma pela qual concebe as formações da produção capitalista, tanto mais ela se aproxima do elemento das ideias corriqueiras, tanto mais, portanto, imerge seu elemento natural. Além disto, presta ótimos serviços a apologética."

Esta é a linha que se apropria à apologética, simples e direta, tornando cada dia mais evidente de que a economia se limita a mera reprodução de fenômenos superficiais, se tornando a ideologia burguesa degenerada e desembocando no liberalismo, ficando nítido que "a decadência da filosofia do progresso se manifesta a partir de um filisteísmo vulgar" (LUKÁCS, 2010, p. 60).

\footnotetext{
A forma científica na qual se manifesta este espírito da pequena burguesia capitalista é o ecletismo, a tentativa de erigir como "método" científico o "por um lado...e por outro", tão caro ao pequeno burguês; de negar as contradições da vida ou, o que é a mesma coisa, de contrapor entre si, de maneira superficial, rígida e carente de mediações, determinações contraditórias. (LUKÁCS, 2010, p. 60).
}

Segundo Coutinho (2010) a burguesia opera de maneiras distintas para a manutenção do status quo, variando de acordo com a sua estabilidade no poder: quanto aos períodos de estabilidade, a burguesia opera com a instrumentalização da razão, ou seja, reduz a simples regras formais o racionalismo, operando com a ideia de práxis manipulatória; já no que se refere aos períodos de instabilidade, os períodos de crise do capitalismo, o pensamento burguês opera com a ideia do irracionalismo, com a destruição da razão.

Com isto percebemos duas orientações numa mesma sincronia, cada uma ocupando uma esfera fetichizada da realidade. Coutinho (2010, p. 45) afirma que compreenderíamos melhor essa cisão se analisarmos logo após a Revolução Francesa (1789), na qual a relação era de recusa ou aceitação das novas formas econômicas que ainda estavam sendo estabelecidas, posteriormente é que as questões éticas e epistemológicas tomam forma.

Surge assim à oposição entre o anticapitalismo romântico e a apologia direta do progresso capitalista (COUTINHO, 2010, p. 45), a primeira via no progresso uma ameaça à subjetividade dos indivíduos isso pela radical socialização do trabalho. Já a apologética burguesa negava as contradições da objetividade econômica afirmando que havia nessas condições: equilíbrio e um progresso linear. Mais tarde essa tendência passa a estabelecer "limites" à compreensão racional da realidade, desembocando no agnosticismo, no 
formalismo apropriando-se do positivismo. Segundo Coutinho (2010, p. 45) a decadência ideológica trata-se, portanto, de uma antinomia que não é superada.

Nesse sentido a decadência caminha para um esvaziamento geral da realidade, e quanto mais este ecletismo se veste com roupagens tanto mais suntuosas quanto mais vazio for (LUKÁCS, 2010, p.60), mascarando o "crítico" e o "revolucionário" se tornando ainda mais perigoso, pois essa mudança de orientação passa a acontecer em todos os campos, não somente na política e na economia, mais na história, na sociologia e na filosofia. Portanto, que a decadência não coloque nenhum problema substancialmente novo, eis um fato que decorre de uma necessidade social (LUKÁCS, 2010, p. 61), pensando no período clássico da ideologia burguesa. As questões que estão em voga são as respostas relativas ao progresso do capitalismo.

\begin{abstract}
A diferença reside "apenas" em que os ideólogos anteriores forneceram uma resposta sincera e científica, mesmo se incompleta e contraditória, ao passo que a decadência foge covardemente da expressão da realidade e mascara a fuga mediante o recurso ao "espírito científico objetivo" ou a ornamentos românticos. Em ambos os casos, é essencialmente acrítica, não vai além da superfície dos fenômenos, permanece no imediatismo e cata ao mesmo tempo migalhas contraditórias de pensamento, unidas pelo laço do ecletismo. (LUKÁCS, 2010, p. 61).
\end{abstract}

Os problemas evidenciados por Lukács (2010) se tratando da decadência ideológica estão relacionado com as contradições relacionadas ao progresso burguês e a divisão social do trabalho, isto por aumentarem cada vez mais as condições alienantes ${ }^{35}$ dos sujeitos. A burguesia no pós 1848 além de se firmar no poder, necessitava de organização para que o "progresso $36 "$ se efetivasse. Tal desenvolvimento está diretamente relacionado com a divisão social do trabalho.

\begin{abstract}
A divisão social do trabalho é muito mais antiga do que a sociedade capitalista, mas - como consequência da amplitude cada vez maior assumida pelo domínio da mercadoria - suas repercussões adquirem uma tal difusão e profundidade que assinalam mesmo uma transformação da quantidade em qualidade. [...] A divisão capitalista do trabalho, portanto, não se limita apenas a submeter a si todos os campos da atividade material e espiritual, mas se insinua profundamente na alma de cada um, provocando nela profundas deformações, que se revelam posteriormente, sob variadas formas, nas diversas manifestações ideológicas. A covarde submissão a estes efeitos da divisão do trabalho, a passiva aceitação destas deformações psíquicas e morais, que são mesmo agravadas e embelezadas pelos pensadores e
\end{abstract}

\footnotetext{
${ }^{35}$ Mecanismos cada dia mais evidentes e sistematizados de (re)produção para a organização do capitalismo. A alienação econômica usurpa das mediações dos sujeitos, se tornando perceptível a contradição trabalho e capital pela propriedade privada. Esta propriedade privada material, imediatamente sensível, é a expressão material e sensível da vida humana alienada. (MARX, 1974, p. 08, Grifos do autor)

${ }^{36}$ Progresso este que não condiz com a $1^{\circ}$ fase da burguesia (progressista), mais sim está intimamente ligada as condições para a sua manutenção no poder e a manutenção do sistema econômico (capitalismo).
} 
escritores decadentes, constituem um dos traços mais importantes e essenciais do período da decadência. (LUKÁCS, 2010, p.62-63).

Nesse sentido nossa compreensão no que se refere ao trabalho acontece no âmbito da objetivação humana, sendo assim é capaz de estabelecer a condição do mundo dos homens e de sua vida material na intervenção intencional sobre a natureza, portanto o trabalho humano é a especificidade do ser social. (HÚNGARO, 2008).

Torna-se evidente que, a partir do modo de produção capitalista, o ser genérico do homem se torna oposto ao ser singular, portanto a generalidade burguesa se torna a própria negação do homem. Gerando assim a incompatibilidade ao gênero, havendo uma nítida contradição entre o indivíduo e o gênero na sociedade capitalista, convertendo os homens a unilateralidade, contraindo os contornos da alienação. (HÚNGARO, 2008).

Com o modo de produção capitalista torna-se fundamental (para a burguesia) a divisão social do trabalho; a primeira divisão que acontece, segundo Lukács (2010), é entre cidade e campo, que segundo Marx (apud Lukács, 2010, p. 62) é [...] a expressão mais brutal da subsunção do indivíduo à divisão do trabalho, a uma atividade prefixada e imposta: uma subsunção que faz do primeiro um mesquinho animal urbano e do outro um mesquinho animal rural [...], a segunda divisão é entre trabalho físico e trabalho espiritual, ambas as cisões ocasionam na transformação da quantidade em qualidade.

Essas divisões influem diretamente na decadência, pois geram especialidades que impossibilitam a compreensão da totalidade, dessa maneira:

\footnotetext{
O fato de que as ciências sociais burguesas não consigam superar uma mesquinha especialização é uma verdade, mas as razões não são as apontadas. Não residem na amplitude do saber humano, mas no modo e direção do desenvolvimento das ciências sociais modernas. A decadência da ideologia burguesa operou nelas uma tão intensa modificação que elas não podem mais se relacionar entre si, e o estudo de uma não serve mais para promover a compreensão da outra. A especialização mesquinha tornou-se o método das ciências sociais. (LUKÁCS, 2010, p.63).
}

Lukács (2010) se coloca a favor de um conhecimento articulado, vinculado com a totalidade, na tentativa de formação omnilateral, entendendo que a categoria da totalidade não é saber tudo sobre todas as coisas mais um todo articulado em um "complexo de complexos" (HÚNGARO 2008).

A crítica que Lukács (2010) tece a Max Weber se apresenta neste sentido, afirmando que esse aspirava a atingir um conhecimento universal sobre a história social; entendendo que as contradições dessa sociedade (a sociedade burguesa) contribuem veementemente para o processo de alienação, porém se limitou a fragmentar a ciência. Segundo Lukács (2010, p. 64) 
Após o surgimento da economia marxista seria impossível ignorar a luta de classes como fato fundamental do desenvolvimento social, sempre que as relações sociais fossem estudadas a partir da economia. Para fugir desta necessidade, surgiu a sociologia como ciência autônoma; quanto mais ela elaborou o seu método, tão mais formalista se tornou, tanto mais substituiu a investigação das reais conexões causais na vida social por análises formalistas e por vazios raciocínios analógicos. Paralelamente a este processo, ocorre na economia uma fuga da análise do processo geral de produção e reprodução, e uma fixação na análise dos fenômenos superficiais da circulação, tomados isoladamente.

A Teoria da Utilidade Marginal surgiu na época do imperialismo, e demarca muito bem as determinações formalistas que tomam força, evidenciando o distanciamento dos problemas sociais das questões econômicas, deixando para trás o que na época clássica havia um esforço para compreender, dessa maneira surgiram os compartimentos entre as áreas.

No campo da economia, surge a teoria da utilidade marginal com a Escola Austríaca de Carl Menger e outros, uma nova concepção que pretende resolver os problemas da burguesia com o marxismo e a teoria da mais-valia. A teoria da utilidade marginal " "cortou os últimos laços que uniam a economia à tradição da economia política clássica. O elemento principal desta ruptura consiste na atribuição de significação subordinada ao trabalho". O princípio do trabalho que a burguesia liberal defendeu contra a propriedade feudal passa a representar um perigo quando o proletariado entra em cena: "Nisto reside a principal razão da mudança de posição da teoria econômica." (LARA, 2013, p. 94).

Antes da decadência, economia e sociologia, na investigação concreta, só eram distinguíveis metodologicamente (LUKÁCS, 2010, p. 64), nesse contexto também estava à história, intimamente ligada ao progresso das formações sociais, no que se refere à época da decadência essas áreas são atingidas, sendo a sociologia direcionada para uma "ciência normativa", a história se limita a uma exposição minimalista e de "unicidade", quanto a economia, esta se torna reduzida a meras análises estatísticas. Sociologia, história e economia se tornam áreas "independentes", do contexto da totalidade social e histórica, não mais se relacionando entre si.

Portanto a crítica a Max Weber, coloca-nos que, embora este reunisse em si um sociólogo, um historiador, um economista e um filósofo, não conseguiu romper com as limitações da decadência, portanto, [...] não significa que fosse possível relaciona-las dialeticamente entre si e levar assim a descoberta de reais conexões do desenvolvimento social [...], (LUKÁCS, 2010, pp. 64) no que diz respeito à filosofia este era seguidor do neokantismo, o que o influenciou a destacar esta separação, o isolamento metodológico e a 
ausência de relação entre teoria e práxis ${ }^{37}$, nesse contexto [...] a teoria ensina um completo relativismo: a igualdade formal de todos os fenômenos sociais, a íntima equivalência de todas as formas históricas.

Reflete-se aqui, no indivíduo, o fato de que, na sociedade capitalista, as atividades profissionais especializadas dos homens tornam-se aparentemente autônomas do processo global. Mas, enquanto o marxismo interpreta esta contradição viva como um efeito da oposição entre produção social e apropriação privada, o aparente contraste superficial é apresentado, pela ciência da decadência, como "destino eterno" dos homens. Deste modo, aos olhos do burguês médio, sua atividade profissional aparece como uma pequena engrenagem num enorme maquinário de cujo funcionamento geral ele não pode ter a mínima ideia. (LUKÁCS, 2010, p. 66)

Portanto, a divisão capitalista do trabalho se da na alteração das consciências deformando-as e limitando-as ao aparente, fragmentando teoria e prática, afetando diretamente a subjetividade e a sensibilidade dos sujeitos, impossibilitando-os que se reconheça na condição do outro, [...] cuja objetividade fatalista e desumanizada se contrapõe, ameaçadora e incompreendida, ao indivíduo (Ibidem).

Tendo em vista a finalidade do sistema metabólico do capital, subordinam-se as necessidades humanas à reprodução do valor de troca. Em decorrência da organização e divisão do trabalho, criou-se uma estrutura de mando verticalizada que hierarquizou a divisão do trabalho tornado possível a introdução desses elementos alienantes visando à necessidade de ampliação de valores de troca. (HÚNGARO, 2008, p. 123).

Marx ao analisar a subordinação do homem a divisão do trabalho, deixa bem claro as condições minimalistas de vida e o caráter animalesco dessa subordinação, essas condições passam a ser reproduzidas porque os homens não se rebelam contra essas condições das formas sociais que lhes são impostas. Já no que se refere ao campo ideológico apresenta-se um embate entre o racionalismo e o irracionalismo, que segundo Lukács (2010, p. 67) o primeiro [...] é uma direta capitulação, covarde e vergonhosa, diante das necessidades

\footnotetext{
${ }^{37}$ Marx ao estudar a sociedade burguesa descobre os determinantes ontológicos do ser social, colocando-nos o que os homens são e quais os seus potenciais, portanto direcionando-nos para a possibilidade de um projeto emancipatório, ficando evidente a necessidade de que "a realidade tenda para a teoria" (HÚNGARO, 2010, p.153), pois, "[...] A coincidência da modificação das circunstâncias com a atividade humana ou alteração de si próprio só pode ser apreendida e compreendida com a práxis revolucionária” (MARX, 1999, p. 12). Apesar de Marx determinar ao proletariado a práxis revolucionária, com as atuais circunstâncias torna-se necessário o envolvimento do coletivo, isto porque [...] Os elementos materiais de uma subversão total são, de um lado, as forças produtivas existentes e, de outro, a formação de uma massa revolucionária que se revolte, não só contra as condições particulares da sociedade existente até então, mas também contra a própria "produção da vida" vigente, contra a "atividade total" sobre a qual se baseia [...] (MARX, 1999, p. 57), sendo assim segundo Húngaro (2008) ao partimos de uma visão ontológica de teoria, a teoria social é a "reprodução ideal do movimento do real" da ordem burguesa; portanto notamos que "a teoria é o subsídio para a ação revolucionária”.
} 
objetivas da sociedade capitalista. O irracionalismo é um protesto contra elas, mas igualmente impotente e vergonhoso, igualmente vazio e pobre de pensamento.

Em contrapartida para Marx o ser humano é considerado a partir do todo, enquanto sensível, portanto os homens se constituem a partir do concreto e do real, sendo assim as falsas representações de si não correspondem a essência do homem real, [...] Os pressupostos de que partimos não são arbitrários, nem dogmas. São pressupostos reais de que não se pode fazer abstração a não ser na imaginação. [...] (MARX, 1999, p. 27). Sendo assim Marx se apoia em bases materialistas históricas, bases essas que dão fundamento aos embates no que se refere ao idealismo, afirmando que [...] São os indivíduos reais, sua ação e suas condições materiais de vida, tanto aquelas por eles já encontradas, como as produzidas por sua própria ação. Estes pressupostos são, pois, verificáveis por via puramente empírica [...] (Ibidem).

Segundo Lukács (2010) no marxismo, a relação entre indivíduo e classe é sempre considerada, isso a partir da complexa dialética da realidade, portanto, os determinantes sociais muitas vezes impossibilitam a emancipação de classe, ficando evidente "os limites da própria classe",

\footnotetext{
$\mathrm{Na}$ realidade, o desenvolvimento social é uma unidade de contradições, viva e dinâmica; é a ininterrupta produção e reprodução destas contradições. Acrescente-se a isto que todo ideólogo, não importa de que classe provenha, está de modo hermético e solipsista aprisionado no ser e na consciência de sua classe apenas para a sociologia vulgar; na realidade, porém, está sempre em face da sociedade como um todo. (LUKÁCS, 2010, p.70).
}

As contradições de que trata Lukács (2010), não se refere somente a contradição entre burguesia e proletariado, mas também as contradições que permeiam internamente a classe burguesa, se os indivíduos compreendessem a densidade das contradições dessa sociedade (a sociedade burguesa) a emancipação humana aconteceria, o que os ideólogos burgueses fazem está diretamente relacionado com a naturalização dessas contradições, contribuindo ainda mais com as condições de deformação humana.

Segundo Lukács (2010) a possibilidade de desenvolvimento dos indivíduos da classe burguesa, rumo a emancipação humana, pode acontecer, [...] A burguesia possui somente a aparência de uma existência humana. Entre aparência e realidade, portanto, deve surgir em cada indivíduo da classe burguesa uma viva contradição [...] (Ibidem, p. 70), sendo assim o autor apresenta quatro possibilidades para os indivíduos dessa classe: 
1) A submissão pura e simples do indivíduo à decadência apologética da ideologia burguesa (sem fazer distinção, bem entendido, entre formas diretas e indiretas, aristocráticas ou triviais, de apologia).

2) A ruptura completa dos indivíduos intelectual e moralmente superiores com sua classe. Este fenômeno, como o Manifesto do Partido Comunista já havia previsto, torna-se um fato social importante notadamente em épocas de crise revolucionária.

3) O trágico fracasso de homens dotados de grandes qualidades diante das contradições do desenvolvimento social e do aguçamento da luta de classes, que não mais têm condições de enfrentar, nem intelectual nem moralmente. [...]

4) O choque dos ideólogos honestos com sua própria classe, o que ocorre na medida em que vivem intensamente as grandes contradições da época, extraem corajosamente as consequências de suas experiências e as exprimem sem hesitações. Este choque, este conflito com a classe burguesa pode, em determinados casos, permanecer por muito tempo inconsciente e latente - e de modo algum deve-se afirmar que ele deva sempre culminar numa adesão consciente ao proletariado. $\mathrm{O}$ significado da situação aqui criada depende da intensidade com a qual o individuo em questão vive e medita sobre as contradições da época, bem como de suas possibilidades - tanto interiores quanto exteriores - de prosseguir por esta estrada, consequentemente, até as últimas instâncias. Trata-se, portanto, em larga medida, de um problema intelectual e moral. (LUKÁCS, 2010, p.72).

O processo de decadência da filosofia e da economia política se instaura no pensamento social, pois o movimento histórico vai contra a ideia da ideologia burguesa, ideia esta que afirma as condições de fragmentação do conhecimento. [...] Nessa medida, o sentido da 'decadência ideológica' é a contraface - absolutamente necessária - do brutal desenvolvimento material e tecnológico deflagrado a partir daí [...] facilitando assim as tradições apologéticas nas Ciências Sociais e nas Ciências Naturais, sendo assim [...] o seu comprometimento passa a se estabelecer tão somente com a reprodução incessante da estrutura sociometabólica do capital, mitigando as resistências e amaciando o curso do controle. (PINASSI, 2009, p. 16).

Após a decadência ideológica muitas foram as tendências que não se preocupavam/am e relevavam/am a modernidade social $^{38}$ ficando explícito os reflexos da decadência nas ciências sociais e naturais. Nas ciências sociais, por mais que haja trabalho sério e verdadeiramente científico os ideólogos burgueses, ainda assim, conseguem se limitar a apologética e a reprodução. Nas ciências naturais, segundo Lukács (2010, p. 72) a situação se agrava pela reprodução reduzida a técnica; [...] o terrorismo filosófico da burguesia atual intimida o materialismo espontâneo de importantes cientistas e os obriga a meditar e

\footnotetext{
${ }^{38}$ Entendemos por modernidade social a constante transformação da ordem burguesa; [...] A burguesia não pode existir sem revolucionar permanentemente os instrumentos de produção - nesse mesmo sentido as relações de produção e consequentemente as relações sociais [...] A continua subversão da produção, o ininterrupto abalo de todas as condições sociais, a permanente incerteza e a constante agitação distinguem a época da burguesia de todas as épocas precedentes [...] Tudo é sólido e estável se dissolve no ar, tudo o que era sagrado é profanado e os homens são , enfim, obrigados a encarar, sem ilusões, a sua posição social e as suas relações recíprocas [...] (MARX; ENGELS, 1998, p. 8)
} 
expressar as consequências materialistas de suas descobertas apenas de modo vacilante, hesitante, diplomático.

\begin{abstract}
Importa-nos aqui a situação geral ideológico-cultural da época da decadência. Nela, é necessário assinalar dois fenômenos concomitantes, que esclarecem vivamente o contraste com relação à época precedente. O primeiro destes fenômenos é que a filosofia não favorece, mas obstaculiza, o desenvolvimento das ciências naturais e, particularmente, a clarificação de seus métodos e de seus conceitos fundamentais. Basta recordar, como contraste, o período anterior à decadência: era um período no qual, de Nicolau de Cusa a Hegel, de Galileu aos grandes cientistas da primeira metade do século XIX, a filosofia e ciências naturais fecundaram-se mutuamente de modo incessante; no qual os cientistas propunham generalizações filosóficas extremamente importantes, enquanto os grandes filósofos, em prosseguimento direto de suas analises metodológicas, encorajavam o desenvolvimento da matemática e das ciências naturais. Em segundo lugar é visível, na vasta ação cultural e ideológica exercida pela vulgarização das teorias científicas, um nítido contraste. No período de ascensão, as grandes descobertas científicas - de Copérnico a Darwin - foram importantes momentos da transformação revolucionária da consciência de massas. Hoje, ao contrário, as grandes descobertas da ciência moderna nos países capitalistas afirmam-se quase sempre passando pelo filtro da filosofia reacionária. Se eles são popularizadas e penetram na consciência das massas, isto não ocorre sem que sejam deformadas num sentido relativista e idealista. O relativismo, a luta contra a aplicação do princípio de causalidade (substituído pela probabilidade estatística), o "desaparecimento" da matéria: tudo isto é utilizado em larga escala visando difundir um relativismo niilista e um misticismo obscurantista. (LUKÁCS, 2010, p. 73).
\end{abstract}

A evolução da decadência fez com que a arte e a literatura ocupassem um lugar diferenciado em relação as ciências sociais e naturais, a sinceridade artística permite ao proletariado um gral de 'liberdade' do qual nas ciências sociais já não mais se encontra, no que se refere a literatura, do ponto de vista imediato, esta somente enfatiza as reais condições sociais em última instância, porém, as contradições internas da sociedade burguesa são as condições para o desenvolvimento da literatura.

Essa possibilidade de liberdade artística e da literatura acontece até o momento em que a burguesia se apropria de tais obras, ocasionando um movimento pseodo revolucionário, do qual domestica até mesmo as interpretações, quando isso acontece cabe ao escritor e ao artista se saturar de determinações ${ }^{39}$ em relação a sociedade, pois quanto mais estes se aprofundarem e conhecerem as deformações sociais, [...] tanto mais os problemas centrais passam ao primeiro plano de seus interesses [...] (LUKÁCS, 2010, p. 75).

Portanto para que o processo dialético ocorra é fundamental que o autor se vincule totalmente a análise da realidade, com os avanços da decadência essa relação, autor e

\footnotetext{
39 Ao nos referirmos ao 'saturar de determinações' correlacionamos a Teoria Social de Marx, [...] Essa teoria social tem validade universal para a ordem burguesa. Temos, aqui, suas possibilidades e limites. Porém, para saturar de determinações a ordem burguesa, Marx acabou por desenvolver um "arsenal de categorias" sobre essa sociedade. Ao mesmo tempo, delineou um método - o qual chamou de o método das sucessivas aproximações ou o método pelo qual se ascende do abstrato ao concreto. (HÚNGARO, 2008, p. 248).
} 
realidade, foi distanciada, gerando transições de renomados autores para a apologética, compartilhando da deformação da realidade de forma naturalizada. Se tratando dos autores que não compartilham dessa lógica é de extrema relevância [...] A sinceridade subjetiva, por certo, é condição imprescindível para o triunfo do realismo, mas fornece apenas sua possibilidade abstrata, não a possibilidade concreta. (LUKÁCS, 2010, p. 76).

\begin{abstract}
Existem casos nos quais uma concepção de mundo politica e socialmente reacionária não é capaz de impedir o nascimento de grandes obras-primas realistas; e existem outros nos quais precisamente a posição política avançada de um escritor burguês assume formas que obstaculizam seu realismo artístico. Trata-se, em suma, de ver se a elaboração da realidade que se expressa na concepção do mundo do escritor abre-lhe o caminho para uma consideração sem preconceitos da realidade, ou se interpõe entre o escritor e a realidade uma barreira que impede sua plena entrega às riquezas da vida social. (LUKÁCS, 2010, p. 76).
\end{abstract}

Torna-se notório que a concepção de mundo focada pela decadência é justamente para atrapalhar e dificultar aos escritores o acesso às contradições da realidade, se tornando mais fácil o acesso à superficialidade, sendo assim,

[...] A quantidade e a qualidade dos preconceitos que o escritor deve superar, sem nenhuma dúvida, crescem com o agravamento da decadência ideológica. A ação negativa da decadência é reforçada ainda pelo fato de que a estética deste período propõe como essência da arte tendências intensamente antirrealistas, agindo assim, também sob este aspecto, de modo desfavorável sobre a evolução dos escritores. (LUKÁCS, 2010, p. 77).

Imersos a esse contexto da decadência, a cada dia que passa se torna mais complicado a sinceridade objetiva, essa não é o que de fato abarca aos escritores burgueses; estes se atém, primeiro - a uma visão restrita da realidade e de suas relações, limitando-se a não denunciar as contradições, conscientemente ou não; segundo - utilizam de um realismo espontâneo, espontaneísmo esse que não se sabe até que ponto contribuiu ou não para o adensamento de uma visão de mundo crítica - no caso de um contraste entre a realidade corretamente percebida e vivida, por um lado, e, por outro, a ideologia e os preconceitos adquiridos. (LUKÁCS, 2010, p. 77).

A ideologia e os preconceitos desse período afastam o foco dos homens, os impedindo de perceber de fato o que é ou não importante; isso se deve aos resíduos ideológicos do capitalismo decadente, para que o realismo de fato ocorra é fundamental que os preconceitos se afastem da própria realidade, em primeiro lugar, e posteriormente da alma, dessa maneira é gerado um processo de ação e reação, 
[...] Mas enquanto a ilusão psicológica da divisão capitalista do trabalho (que já descrevemos acima) não for destruída pelo escritor em sua atividade criadora; enquanto ele aceitar como moeda corrente, também em sua obra, o contraste decadente e fetichizado entre intuição e intelecto, e não captar, em seu trabalho de escritor e de criador de personagens, a unidade oculta e contraditória de ambos; enquanto isto não ocorrer, não pode surgir nele aquela cultura dos sentimentos sem a qual é impossível uma literatura realista, verdadeiramente significativa. (LUKÁCS, 2010, p. 78).

Nesse conturbado contexto histórico que resulta a alienação da generalidade do homem e de sua essência, a criação e contentamento de novas necessidades alienadas passam a ser a força motriz. As necessidades se tornam apenas individuais, cedendo espaço a uma essência egoísta e de rápidas paixões, paixões que correspondem somente ao ter. Surge então uma tensão entre o burguês e o cidadão ${ }^{40}$, se tornando as ações coletivas direcionadas para a essência particular, manifestando então a singularidade extrema: portanto os meus desejos se sobrepujam aos da coletividade, dessa forma as necessidades, as que de fato efetivam a essência do ser social, reais ficam a mercê, sendo distorcidas pela rendição a propriedade privada, a riqueza e ao dinheiro. (ALVES, 2015).

Há, portanto, a necessidade de integração da vida sentimental com a vida intelectual, não no sentido vulgarizado, mais sim no sentido de emancipação, vinculando a possibilidade de transformação por princípios humanistas, princípios esses que foram abandonados pós 1848. Segundo Lukács (2010) a 'cultura dos sentimentos' se renovou, trazendo a tona novamente a necessidade de evolução da humanidade pela cultura socialista, em contrapartida,

[...] o escritor burguês nem dispõe de uma justa concepção do mundo, nem entra em contato com um círculo de leitores que, graças a energia de seus sentimentos e à sua vitalidade política e social, seja capaz de levá-lo a se desenvolver no sentido de uma verdadeira cultura dos sentimentos. Ele, na realidade capitalista, está geralmente abandonado a si mesmo. (LUKÁCS, 2010, p. 79).

Marx (1974) problematiza, sinteticamente, a separação entre sujeito e objeto, sendo fundamental [...] O superar, como movimento objetivo que retoma a si a alienação. É esta a

\footnotetext{
${ }^{40}$ Marx (2010) define a diferença entre Homme e Citoyen: o Homme é o homem da sociedade burguesa, este é chamado de homem para que os direitos estabelecidos sejam chamados direitos humanos; já no que diz respeito ao Citoyen temos o cidadão, aquele que se diz legitimado pelos direitos da sociedade burguesa, sendo esse direito a impossibilidade da sua liberdade devido a garantia da propriedade privada. “ [...] A liberdade equivale, portanto, ao direito de fazer e promover tudo que não prejudique a nenhum outro homem. $\mathrm{O}$ limite dentro do qual cada um pode mover-se de modo a não prejudicar o outro é determinado pela lei do mesmo modo que o limite entre dois terrenos é determinado pelo poste da cerca. Trata-se da liberdade do homem como mônoda isolada recolhida dentro de si mesma. [...] No entanto, o direito do humano à liberdade não se baseia na vinculação do homem com os demais homens, mas, ao contrário, na separação entre um homem e outro. Trata-se do direito a essa separação, o direito do indivíduo limitado, limitado a si mesmo. A aplicação prática do direito humano à liberdade equivale ao direito humano a propriedade privada." (Ibidem, p. 49, Grifos do autor).
} 
concepção que se expressa no interior da alienação, da apropriação da essência objetiva mediante a superação da alienação [...] (Ibidem, p. 44), portanto ao interagir com o mundo objetivo, o homem se humaniza, quando o mundo torna-se real o sujeito estabelece relações, relações essas que propiciam uma natureza humanizada. Quando o homem se relaciona humanamente com mundo objetivo, supera a alienação de si mesmo, representando o regresso do homem como ser social, sendo assim [...] a concepção alienada na objetivação efetiva do homem, na apropriação efetiva de sua essência objetiva mediante a aniquilação da determinação alienada do mundo objetivo, mediante sua superação, no seu modo de existência alienado [...] (Ibidem), dessa maneira há o desencadeamento do processo de humanização.

\begin{abstract}
A capacidade de atingir um tal conhecimento intimo do homem é o triunfo do realismo na literatura. É evidente que um escritor pode se abrir para uma tal concepção do homem somente quando houver superado, em si mesmo, os preconceitos equivocados que a burguesia divulga sob as mais variadas formas a respeito do homem e do mundo, do indivíduo e da sociedade, da vida interior e exterior da pessoa humana. (LUKÁCS, 2010, p. 81).
\end{abstract}

Sendo assim quando retomamos as leituras de Marx nos deparamos com as possibilidades para motivação da prática revolucionária, pois o conteúdo da obra marxiana permite a alteração das condições objetivas dos sujeitos, daí a importância de retomarmos os fundamentos do humanismo marxista, pois além de investigador do problema do indivíduo humano, era um lutador pela felicidade. (SCHAFF, 1967).

O homem nasce na sociedade burguesa, sendo submetido a determinadas condições sociais, condições essas que ele não escolhe e que são determinadas pela produção, sendo assim [...] ergue-se toda a complicada estrutura de concepções, sistemas de valores e instituições ligadas a ela [...] (SCHAFF, 1967, p. 71). Portanto, [...] o homem não é um ser abstrato, acocorado fora do mundo. O homem é o mundo do homem, o Estado, a sociedade. [...] (MARX, 2013, p. 151, Grifos do autor), além de estar ligado ao mundo e a sociedade, o homem também é constituído e criado por este mundo, sendo as condições sociais determinantes para a constituição do indivíduo humano.

Contudo, autoconhecimento e conhecimento do mundo são inseparáveis. Não é possível que o homem supere em si mesmo os traços da decadência sem conhecer e compreender as mais profundas estruturas da vida, sem quebrar a casca superficial que, no capitalismo, recobre as ligações mais ocultas e a mais oculta unidade contraditória; aquela casca que a ideologia da decadência mumifica e vende como algo definitivo. (LUKÁCS, 2010, p. 81). 
Neste contexto, quanto mais se saturar o objeto de determinações maiores serão as possibilidades de mediações com a realidade, facilitando assim as condições de emancipação dos sujeitos. Portanto, [...] Investigar, para Marx, é buscar essas determinações do objeto. $O$ conhecimento do objeto é tanto maior quanto maior forem as determinações encontradas, ou seja, quanto mais se satura o objeto com determinações maior é o conhecimento a respeito dele. (HÚNGARO, 2008, p. 87).

\begin{abstract}
A profundidade da intuição estética, da aproximação realista à realidade, é sempre constituída - qualquer que seja a concepção do mundo formulada pelo escritor no nível conceitual - pelo impulso a nada aceitar como resultado morto e acabado e a dissolver o mundo humano numa viva ação recíproca dos próprios homens. Portanto, todo realismo verdadeiro implica a ruptura com a fetichização e com a mistificação. Quando os preconceitos da sociedade classista são tão enraizados num escritor que tornaram impossível esta dissolução da sociedade nas mútuas relações humanas, ela deixa de ser realista. (LUKÁCS, 2010, p. 81).
\end{abstract}

O segredo está em despertar no homem a necessidade real de reconhecer-se no outro, sendo assim [...] A verdadeira riqueza espiritual do indivíduo depende inteiramente da riqueza de suas relações reais [...] (MARX apud LUKÁCS, 2010, p. 81). A partir do momento que suas relações se tornam superficiais desembocamos em um imediatismo sem fim, se tornando a literatura o retrato do esvaziamento e um campo de experiências formalistas. [...] Desta essência da literatura, decorre o problema da substancial moralidade social do escritor realista e da importância de sua honestidade, de sua energia e de sua coragem. [...] (LUKÁCS, 2010, p. 82).

É fundamental que a apreensão da realidade aconteça a partir da totalidade dialética, movido pela práxis humana, movimento em que o sujeito histórico se torne portador dos interesses universais e a totalidade dialética seja a apreensão da realidade concreta, sendo assim se torna explícito que para o autor,

[...] É necessário que ele ponha a prova suas próprias experiências e movimentos do espirito, examinando sua gênese e sua possibilidade de se converter em práxis humana. Se a literatura decadente exclui cada vez mais de sua estética a ação e o enredo, considerados como "anacrônicos", isto ocorre para que possam ser defendidas as tendências da decadência. (LUKÁCS, 2010, p. 82).

A partir do momento que se exclui da estética literária, a ação e o enredo, surgem brechas para a fragmentação do real, portanto a negativa do desenvolvimento histórico-social. Ao invés da reprodução artística contribuir para a práxis revolucionária, o desembocar na filosofia da decadência aparta a realidade da teoria. 
[...] toda domesticação da realidade, por grosseira ou refinada que seja, significa substancialmente a mesma coisa, e que o falso e desenfreado subjetivismo da práxis literária contém necessariamente a possibilidade de domesticar a realidade, ou, antes convida a domesticá-la. E os mecanismos do capitalismo, por sua vez, procuram fazer com que o enfraquecimento da resistência do escritor seja utilizado em seu benefício. (LUKÁCS, 2010, p. 83).

Para Lukács (2010) é fundamental a superação dos limites das impressões objetivas, demonstrando amor pela vida e pelos homens, que para além das misérias humanas existe uma constante busca pela felicidade e o reconhecimento do ser enquanto humano. Sendo assim a fantasia se torna uma das formas de negligencia da deformação da realidade, nesse contexto da decadência o primordial e relevante é o desenvolvimento a partir do históricosocial.

$\mathrm{O}$ ato consciente de suas ações se tornam cada vez mais distantes dos personagens, tomando as cenas os sentimentos dos autores, tornando superficial as relações sociais e não superando os limites das impressões subjetivas, segundo Lukács (2010) a literatura cria caricaturas do próprio homem, reforçando as imposições do sistema e deturpando o "SER HUMANO". Sem um tal amor pela vida e pelos homens, amor que implica necessariamente o mais profundo ódio pela sociedade, pelas classes e pelos homens que os humilham e os ofendem, não podem surgir hoje no mundo capitalista um realismo verdadeiramente grandioso.

\footnotetext{
Apesar da extraordinária variedade exterior dos temas e dos modos de desenvolvêlos, encontramos nesta aproximação de falsa objetividade - porque morta - e de falsa subjetividade - porque vazia - a velha definição marxiana da ideologia da decadência: imediatismo e escolástica. (LUKÁCS, 2010, p. 85).
}

Marx aponta para importância do caráter social do homem e da sua tomada de consciência, portanto o processo de humanização acontece a partir das riquezas produzidas historicamente, ou seja, a cultura como patrimônio do gênero. A partir dessas relações que são estabelecidas percebe-se a necessidade do outro para a constituição do ser, ou seja, o retorno do a si enquanto homem social, isto é, humano. A partir do momento que a deformação da realidade se torna o centro, não mais podemos considerar enquanto patrimônio universal e sim como negação do gênero. (ALVES, 2015).

Partindo da alegação "sou social, porque atuo como homem” (MARX, 1974, p. 10), percebe-se que tanto o objeto quanto o sujeito são resultados da materialização e da exteriorização das relações sociais com outros homens, a sociedade produz os homens e os 
homens produzem e reproduzem, portanto o movimento mais geral do ser é determinado "em si" e "para si".

\begin{abstract}
No curso da evolução da totalidade da teoria e da práxis literárias da decadência, pode-se constatar como, do lado burguês, a figuração de homens reais em conflitos reais seja intensamente atenuada, de modo a adaptar-se àquele nível de humanidade que a barbárie crescente do capitalismo tem condições de tolerar. Para sermos mais precisos: a teoria da decadência humana coloca como tarefa à arte não mais representar a real existência humana no capitalismo, mas sim aquela aparência de existência da qual falava Marx [...]. Ela exige que o escritor represente esta aparência como o único modo de ser possível e real aos homens. (LUKÁCS, 2010, p. 87).
\end{abstract}

A filosofia da decadência se constitui pela ideologia capitalista e todo o tempo se evade das contradições do sistema capitalista, na tentativa de gerar conformidade, aprimorando as inumanidades do capitalismo. O espírito pequeno-burguês só pode ser intimamente superado por uma verdadeira compreensão dos grandes conflitos e das crises do desenvolvimento social, porém o atual contexto tem mostrado apelações para a interioridade da vida humana, desprezando os conflitos externos.

[...] já que está ausente a verdadeira luta dos homens com a sociedade e na sociedade; estão também ausentes as determinações objetivas da vida humana, das quais apenas a alma recebe e explicita a sua íntima riqueza; são afastadas com plena consciência e intencionalidade artísticas, todas as premissas de uma figuração verdadeiramente profunda dos homens. (LUKÁCS, 2010, p. 89).

Percebe-se, portanto que o sistema cria e recria condições para se manter e manter a cultura do consumo, sendo todas as funções reprodutivas sociais subordinadas as formas que são criadas [...] - das relações de gênero familiares à produção material, incluindo até mesmo a criação das obras de arte - ao imperativo absoluto da expansão do capital, ou seja, da sua própria expansão e reprodução como um sistema de metabolismo social de mediação. (ANTUNES, 2009, p. 23).

Em tais condições, social e ideologicamente pouco propícias, a sinceridade do escritor deve ir decisivamente além, portanto, do aspecto formal-subjetivo; deve acolher um conteúdo social e ideológico, deve se orientar, graças a este conteúdo, na direção de uma abertura para a realidade e suscitar em face desta realidade uma íntima e profunda confiança, única condição da qual pode decorrer a coragem do escritor na reprodução do mundo no qual ele pôde assim penetrar. (LUKÁCS, 2010, p. 77).

Cabia, então, em seu projeto de manutenção da dominação, desqualificá-las ou empobrecê-las. [...] Nessa fase, suas elaborações teóricas passam a estimular, em momentos 
de estabilidade, a Razão Instrumental e, em momentos de crise, o Irracionalismo. ${ }^{41}$

(PATRIARCA, 2012, p. 24), esses são os desdobramentos da decadência ideológica, que apresentaremos a seguir.

\subsection{1 - O Irracionalismo}

Paralelamente à decadência do capitalismo e ao aguçamento das lutas de classes em decorrência de sua crise, o irracionalismo apela - sempre mais intensamente - aos piores instintos humanos, às reservas de animalidade e de bestialidade que necessariamente se acumulam no homem em regime capitalista. Se as mentirosas fórmulas demagógicas do fascismo, é grande a responsabilidade que recai objetivamente sobre a filosofia e a literatura da decadência, que evocam estes instintos nos leitores e contribuem de fato para o cultivar, embora, na maioria dos casos, não pensassem sequer longinquamente nas aplicações práticas que deles faria o fascismo, e até mesmo, muito frequentemente, as condenassem com indignação. (LUKÁCS, 2010, p. 68).

A denúncia de Lukács (2010) está para além da decadência ideológica, sua denúncia perpassa os desdobramentos da decadência que tem como consequência a contribuição do irracionalismo para o esvaziamento da alma humana, afirmamos isso por que se a realidade não é apreendida como um todo, consequentemente o real se tornará o efêmero, pois o imediato substitui o mediato, segundo Evangelista (1992) três são as características do irracionalismo pós-moderno: a desreferencialização do real; a dessubstancialização do sujeito e o descentramento político ${ }^{42}$.

Se é impossível a descoberta de um sentido no processo histórico-social, que possa ser racionalmente apreendido, instaura-se o império da incognoscibilidade com a relativização de todo conhecimento, permitindo uma multiplicidade inesgotável de interpretações, todas válidas. A realidade teria como característica essencial o

\footnotetext{
41 Segundo Coutinho (2010, p. 16-17) [...] Embora aparentemente opostas, essas posições unilaterais são complementares. Tanto o irracionalismo quanto o "racionalismo" formalista (do qual o estruturalismo é apenas uma manifestação) são expressões necessárias do pensamento ideológico da burguesia contemporânea, incapaz de aceitar a razão dialética, a dimensão histórica da objetividade, a riqueza humanista da práxis. [...] A ponte entre o irracionalismo e o racionalismo formal é constituída pelo agnosticismo. Confundindo a razão com o intelecto, a apropriação humana da objetividade com a manipulação técnica ou burocrática de "dados", as correntes formalistas desembocam num agnosticismo mais ou menos radical. Esferas fundamentais da realidade objetiva - exatamente as denotadas pelas categorias da dialética, história e humanismo - são declaradas incognoscíveis, "falsos problemas", e, consequentemente, lançadas no terreno da irrazão e do irracionalismo. Os limites do racionalismo formal, portanto, são o ponto de partida para a arbitrariedade irracionalista.

${ }^{42}$ Segundo Evangelista (1992) esses são três aspectos principais da expressão da pós-modernidade, a desreferencialização do real - significa a deturpação do real, deixando de ser referência para a verdade, portanto, negando as contradições da sociedade; dessubstancialização do sujeito - o sujeito não é mais reconhecido enquanto ser de classe e revolucionário, sendo assim o reconhecimento do sujeito se torna o reconhecimento dos sujeitos, cada um em busca de suas peculiaridades; descentramento político - a partir do momento que o sujeito deixa de ser reconhecido enquanto classe, consequentemente [...] A revolução, enquanto objetivo histórico de macrotransformações, é substituída pelas pequenas lutas moleculares e estas não possuem estratégias unificadas nem coordenação. (HÚNGARO, 2008, p. 145).
} 
fragmentário, que impede qualquer possibilidade de síntese ou totalização, que apreenda o real. (EVANGELISTA, 1992, p. 31).

A proposta do irracionalismo desemboca na homogeneização e manipulação das contradições da realidade - daí a afirmação de que a elaborações teóricas em tempos de crise partem do irracionalismo, portanto, desembocando no movimento da pós-modernidade considerando os momentos ontológicos da realidade como incognoscíveis ou irracionais (COUTINHO, 2010), consequentemente desconsiderando o sujeito histórico-social (o sujeito ontológico) e suas condições de classe, sendo assim,

[...] A antítese burguesa do irracionalismo, o positivismo agnóstico, desenvolve a tendência dos primeiros apologetas diretos do capitalismo. Sublimada em questões metodológicas, a característica essencial dessa orientação consiste em afastar da realidade (e consequentemente, das categorias racionais que a refletem) os problemas conteudísticos, os problemas da contradição. (COUTINHO, 2010, p. 50).

As possibilidades de superação dessas condições irracionais impostas se tornam possíveis a partir da problematização de Marx em relação à realidade, compreende-se que esse problematiza a realidade através de uma totalidade articulada ao "complexo de complexos" (Lukács, 1979). Problematização esta que não busca abranger uma compreensão sobre todas as coisas, mas, especialmente, de que todas as coisas estão interligadas entre si, por isso, trata-se de um “complexo de complexos" (Lukács, 1979), por isso afirmamos ser falso o consenso sobre a materialização da pós-modernidade, adiante tentaremos explicitar melhor tal argumento.

\subsubsection{1 - O Falso Consenso Sobre a Materialização da Pós-modernidade ${ }^{43}$}

[...] o pós-modernismo significa a lógica cultural do capitalismo avançado ou tardio. A produção cultural foi assimilada pela produção de mercadorias em geral, onde a inovação e a experimentação estéticas passaram a ter uma função estrutural essencial diante da necessidade frenética de produzir uma infinidade de novos bens com uma

\footnotetext{
43 “O novo espirito do tempo encontrará a sua formulação mais conhecida precisamente num texto de 1979: $A$ condição pós-moderna, de J.-F. Lyotard ${ }^{82}$ - tendências epistemológicas gestadas há muito, resgates seletivos do neopositivismo e a herança do estruturalismo confluem neste pequeno ensaio que, em especial graças a midiatização cultural própria da França pós-68 (e, em seguida, de praticamente todo o mundo ocidental), para muitos estratos intelectuais se tornou fundacional. Mas há que se ressaltar que as expressões do pensamento pósmoderno não nascem em 1979, como já o demonstrou uma acreditada documentação ${ }^{83}$; ademais, no seu eclético substrato comparecem autores e linhagens intelectuais que de longe antecedem o espírito do tempo que ela encarna ${ }^{84}$. É, porém, seguramente a partir do livrinho de Lyotard que o pensamento pós-moderno assume o primeiro plano na cultura do Ocidente capitalista, irrompe nos domínios do saber, invade as manifestações estéticas, contagia as práticas políticas e, nas duas décadas seguintes, constituirá um campo teórico diferenciado e desencadeará a produção de uma bibliografia enorme, muito mais apologética que crítica ${ }^{85 . " ~(N E T T O, ~ 2010, ~ p . ~}$ 256).
} 
aparência cada vez mais nova. A cultura, mais do que nunca, passou a ser uma esfera central do processo de reprodução social, invadindo e recobrindo todos os espaços da sociabilidade. Com a pós-modernidade, há "a transformação da cultura em economia e da economia em cultura. É uma imensa 'desdiferenciação' [...], na qual as antigas fronteiras entre a produção econômica e a vida cultural estão desaparecendo". (EVANGELISTA, 2001, p. 31).

A primeira questão a ser tratada advém da tensão entre modernidade e o movimento da pós-modernidade ${ }^{44}$. A primeira morte anunciada da modernidade não é recente como demonstram os textos que tratam de seu "fim" como uma condição histórica. De acordo com Wood (1999), durante a I Guerra Mundial, Oswald Spengler escreveu A Decadência do Ocidente que narrava o término da civilização ocidental. Depois de algum tempo, Wright Mills em A Imaginação Sociológica afirmou que estaria iniciando-se a "Era Pós-Moderna".

\begin{abstract}
Entre esses dois anúncios do declínio de uma época, o primeiro publicado em 1918 e o segundo, em 1959, há, claro, grandes divergências ideológicas - os sentimentos antidemocráticos de Spengler contra o radicalismo de Wright Mills; a hostilidade (ou, pelo menos, a ambivalência) do primeiro ao Iluminismo versus a aceitação, ainda que um tanto inútil, dos valores desta doutrina pelo segundo. Mas há também a contribuição de uma catastrófica história de depressão, guerra, genocídio, a que se seguiu uma promessa de prosperidade material - uma excedendo os piores receios da humanidade até o presente, a outra, as esperanças mais visionárias.” (Wood, 1999, p. 7-8).
\end{abstract}

Apesar de suas diferenças, essas análises possuíam algo em comum: tratavam o Fim da Modernidade como uma condição histórica [...] (HÚNGARO, 2008, p. 121). Com o passar do tempo, percebe-se que o movimento da pós-modernidade decorre da negativa da história, até mesmo de sua própria história; negando que estes mesmos emergem de uma conturbada situação histórica, enfatizando então os imediatismos e modismos do presente fazendo das aparências certezas consideráveis.

Outro problema recorrente é a enfática generalização dos autores pós-modernos, estes não consideram que a Modernidade decorre de heterogeneidade. Assim, por exemplo, tratam Marx e Comte como modernos sem mostrar as importantes diferenças entre eles [...] (PATRIARCA, 2012, p. 45). Nesse mesmo sentido a agenda pós-moderna também não se constituiu/i de forma homogênea e sim heterogênea, portanto, podemos afirmar sobre as várias "agendas pós-modernas" ou "pensamentos pós-modernos". Portanto se tornando perceptível uma agenda anticapitalista e outra de alusão ${ }^{45}$.

\footnotetext{
${ }^{44}$ Segundo Húngaro (2008), o termo movimento é utilizado, pois não há subsídios históricos que apontem para um novo processo civilizatório, portanto se não houve mudanças de tal ordem não podemos chamá-lo de pósmodernidade.

${ }^{45}$ Rodrigues (2006, p. 27) confirma essa diferença de agendas no movimento [...] Como Boaventura de Souza Santos - intelectual declaradamente pós-moderno - adverte, há um pós-modernismo de oposição ou de
} 
Em especial o sentido pós-moderno de novidade que marca uma época depende de ignorarmos, ou negarmos, uma realidade histórica esmagadora: a unidade "totalizante" do capitalismo, que costurou todas as rupturas memoráveis ocorridas neste século. Isso nos leva à característica mais notável dos novos pós-modernistas: a despeito de uma insistência em diferenças e especialidades que marcam épocas, a despeito de sua reinvindicação de terem denunciado a historicidade de todos os valores e conhecimentos (ou precisamente devido à sua insistência na "diferença" e na natureza fragmentada da realidade e do conhecimento humano), eles são impressionantemente insensíveis á história (WOOD, 1999, p. 14).

Este "novo" padrão societário apresenta ideais fragmentados renunciando e negando as contradições da totalidade do real. Portanto, este movimento da pós-modernidade surge como artimanha do mercado, isto para manutenção do trabalho alienado e da cultura de massa, pois, quanto mais fragmentado o conhecimento do trabalhador, melhor é para que o trabalhador atenda as suas necessidades imediatas e contribua com o acúmulo de capital da burguesia. Baseado nisto, é importante apontar, também, alguns aspectos acerca do movimento da pós-modernidade, aspectos estes que aceleraram as condições para que o movimento se difundisse a tal ponto, algumas foram às condições que contribuíram:

a) condições econômicas, representadas pelo esgotamento do longo ciclo expansivo da economia capitalista ocidental, iniciado depois da $2^{\text {a }}$ Guerra Mundial e que se encerra em meados dos anos 1970, que pôs em xeque os fundamentos do padrão fordista-keynesiano de acumulação capitalista e ensejou a hegemonia neoliberal a partir dos anos 1980; b) condições técnicas, entendidas como a existência consolidada de uma indústria cultural, capitaneada pela televisão, que se torna quase onipresente na vida cotidiana, e a difusão de novas tecnologias de comunicação que permitem o surgimento de novas formas de produção cultural baseadas na telemática e na simulação de imagens eletrônicas; c) condições socioculturais, identificadas com a expansão de novos contingentes de profissionais de formação universitária, caudatários do movimento de contracultura dos anos 1960, que integram as camadas médias assalariadas, configurando o que alguns denominaram de uma "nova classe média", com participação ativa no circuito ampliado de produção e consumo de bens culturais; e d) condições políticas, estabelecidas por uma derrota estratégica de longo alcance histórico de movimentos sociais e forças políticas radicais e/ou revolucionárias, que altera os vetores dominantes no cenário político e ideológico. (EVANGELISTA, 2007, p. 78-79).

Já não mais se estuda macroestruturas e sim fenômenos específicos, sendo a verdade, aparentemente, determinada pelos fragmentos do real, de forma que o aparente se torna a verdade, acontecendo do imediato substituir o mediado, portanto a objetividade é reduzida ao

contestação que, embora parta da premissa do esgotamento da modernidade, reclama a constituição de uma nova epistemologia e de uma nova condição social que permita a realização das promessas que a era moderna não tem mais condições de realizar. Há também um outro pós-modernismo, denominado de celebração, que interpreta a exaustão da modernidade como o colapso não só de suas promessas, mas também de qualquer alternativa às práticas sociais da modernidade. Veremos, mais adiante, que a cultura pósmoderna, mesmo em suas vertentes mais críticas, não deixa de ser uma antiontologia. 
simbólico substituindo, então, a própria realidade. [...] Este caráter se reproduz em homem que não se rebela, de um modo real e concreto, contra estas formas sociais [...] (LUKÁCS, 2010, p. 67).

Desde a década de 1960, as discussões do movimento pós-moderno têm sido introduzidas e incididas tanto na educação quanto no contexto acadêmico como um todo. Há muitos equívocos quanto às críticas efetuadas pelos pós-modernos: visão reduzida da realidade e distorção da totalidade, são algumas. Estes erros se dão pela sujeição as demandas da ordem burguesa.

\footnotetext{
Não trabalhamos com a noção de que as manifestações ideológicas sejam um simples reflexo da estrutura societária fundamental, ou então que sejam mecanicamente determinadas por esta; na verdade, nós as interpretamos como totalidade. Assim, não há dúvidas de que o chamado debate pós-moderno tem como estimuladoras as transformações societárias recentes, especialmente os acontecimentos políticos do final dos anos 80 . Claro que as suas origens remontam a meados dos anos 70, mas o processo de esfacelamento do socialismo real foi fundamental em seu fortalecimento e o quadro traçado por Eagleton é por demais revelador. Poderíamos, inclusive, talvez argumentar que, do ponto de vista político, 1968 seja um marco para o desenvolvimento da crítica pós-moderna, e isso é em parte verdadeiro, mas o culminar do processo é, de fato, a chamada "crise do socialismo". (HÚNGARO, 2008, p. 135).
}

Partindo desse conturbado contexto histórico Della Fonte (2011) nos direciona para três pilares baseado em Marx e Lukács: primeiro, de que a realidade existe e é cognoscível; segundo, de que objetividade não significa neutralidade e totalidade não é tudo, por fim, de que ser contra o relativismo cultural não é ser contra a multiplicidade da cultura.

Ao afirmarmos que a realidade existe e é cognoscível direcionamos o debate para o enriquecimento em si partindo da realidade, sendo este enriquecimento da consciência direcionado para si, utilizando dos fatores históricos em detrimento dos fatores causais da realidade, não desconsiderando que a realidade é o aparente e para que esta seja relevada pela historicidade é fundamental uma análise para além do aparente, quebrando com as ideias relativistas (DELLA FONTE, 2011).

Quando apontamos que a objetividade não significa neutralidade e totalidade não é tudo, partimos dos Manuscritos econômico-filosóficos, em que considera-se todo existente enquanto objeto, sendo estes parte de um complexo concreto, sendo os seres humanos diferenciados por relações entre estes e consequentemente históricas e sociais, portanto é a "anatomia do homem que explica a anatomia do macaco", ou seja, do mais evoluído para o menos evoluído (DELLA FONTE, 2011). 
Portanto, afirmar que totalidade corresponde a tudo e todas as coisas é outra ideia distorcida; totalidade corresponde a ideia de que todas as coisas estão interligadas entre si, sendo assim a objetividade implica diretamente na totalidade da história. Após situarmos tais conceitos, estabelecidos por Della Fonte (2011), é de extrema relevância que compreendamos que as formulações multiculturais não estão em defesa da diversidade cultural, mais em busca de um relativismo ontológico e do ceticismo epistemológico;

\begin{abstract}
Uma coisa é aceitar um "relativismo cultural" que respeita a variedade da cultura humana; outra, inteiramente diferente, é adotar um relativismo que transforma esses valores culturais variados no único ou principal padrão de verdade, de modo que a verdade passa a ser simplesmente o que se ajusta a um dado sistema de crenças, ao invés de aquilo que descreve fielmente o mundo que existe independentemente de nossas crenças. (NANDA, 1999, p.100).
\end{abstract}

Entendendo que o movimento da pós-modernidade tem produzido conhecimentos científicos sobre determinados setores da realidade, é importante que a ciência se questione sobre o que se tem produzido, ou seja, que ela se proponha a problematizar suas próprias objetivações, mormente, em razão do impacto ideológico que elas podem assumir no desenvolvimento social e diretamente relacionados ao trabalho educativo que muitas vezes contribuem para a instrumentalização dos seres sociais.

\begin{abstract}
Esse "novo" irracionalismo pode ser caracterizado, resumidamente, pela "desreferencialização do real", pela "dessubstancialização do sujeito" e pelo "descentramento da política" (Evangelista, 1992, p. 25). Há também, um ataque a categoria da totalidade, apenas o micro pode ser entendido. Em síntese, a decadência ideológica do pensamento burguês está expressa em dois movimentos importantes: o empobrecimento da razão - "a miséria da razão" - cuja expressão significativa é a hipertrofia da razão instrumental; e o estímulo a um novo irracionalismo que se centra, fundamentalmente, no ataque a toda e qualquer impostação de totalidade. (PATRIARCA, 2012, p.42).
\end{abstract}

A tentativa de destruição da razão ${ }^{46}$ está diretamente atrelada ao projeto conservador defendido pela burguesia, sendo caracterizado pelo acúmulo de riquezas e exploração da força

\footnotetext{
46 "Os germes da "destruição da razão" - que apareceram pela primeira vez no começo do período monopolista ou imperialista - frutificam em ideologias fascistas ou criptofascistas do período entre guerras. Apesar da bajulação contemporânea às ciências exatas, da aura dos especialistas e do culto às viagens espaciais, o irracionalismo continuou florescendo de diversas formas desde a Segunda Guerra Mundial. Sugestivamente, difundiu-se agora em larga escala nos países anglo-saxões que antes da Segunda Guerra Mundial ainda eram dominados pelo pragmatismo burguês-racionalista. [...]. A estrutura social e a ideologia do capitalismo tardio também inculcam o empenho compulsivo pelo sucesso e submissão mecânica à "autoridade tecnológica", o que frequentemente gera tensões neuróticas. Essas formas de comportamento, com a consequente eliminação do pensamento crítico ou da consciência, e o treinamento a cega obediência e ao conformismo, potencialmente criam pré-requisitos perigosos para a aceitação semifascista de ordens desumanas, por razões de conveniência ou hábito". (MANDEL, 1982, p. 355).
} 
de trabalho, sendo que as teorias que vão surgindo atendem às demandas e interesses do capital.

Como conseqüência desse tipo de abordagem, fica possível afirmar o fim da Modernidade sem terem chegado ao fim os determinantes históricos que a possibilitaram. Mais que isso, torna-se possível a afirmação de que as formas de pensar da Modernidade são opressoras e precisam ser superadas. Dessa forma, o problema não estaria no capitalismo e sim nas expressões teóricas que constituíram o projeto da modernidade (HÚNGARO, 2001, p. 126).

Baseado nisto, é importante apontar, também, alguns aspectos ${ }^{47}$ acerca do movimento da pós-modernidade para adensar os argumentos que articulem um debate que se contraponha a ele, sustentado pela pertinência da ontologia do ser social, tentaremos apresentar os fatos históricos que influenciaram para o desdobramento desse movimento e atingiu diretamente a economia, a política, o social, a cultura, a arte e a ciência. Por mais que os apresentemos separadamente compreendemos que esses aspectos compõem um todo articulado, em que as mudanças em um dos aspectos interferem diretamente no outro, portanto um processo de interação dialética.

[...] não há como negar que as formulações pós-modernas e suas repercussões dãose, fundamentalmente, no âmbito cultural, no qual a totalidade da realidade humana está posta, assim como em qualquer dimensão do ser social. Dessa forma, o debate sobre a pós modernidade, que aparenta ser um debate travado no âmbito cultural, é, na verdade, um debate sobre as circunstâncias, os limites estabelecidos por essas circunstâncias, bem como as possibilidades do ser social na ordem tardo-burguesa. (HÚNGARO, 2008, p. 136).

\title{
1.2.1.1.1 - A Economia
}

\begin{abstract}
Ao longo de sua existência, o capitalismo moveu-se (move-se) e transformou-se (transforma-se); mobilidade e transformação estão sempre presentes nele: mobilidade e transformação constituem o capitalismo, graças ao rápido e intenso desenvolvimento das forças produtivas que é a sua marca. A expressão sociopolítica das suas contradições, que surge nas lutas de classes, permeia e penetra todos os passos da sua dinâmica. A história do capitalismo - a sua evolução - portanto, é produto da interação, da imbricação, da intercorrência do desenvolvimento das forças produtivas, de alterações nas atividades estritamente econômicas, de inovações tecnológicas e organizacionais e de processos sociopolíticos e culturais
\end{abstract}

\footnotetext{
47 Segundo Netto (2010, p. 257) "Considerada na sua inclusividade, tais mudanças operam, sem quaisquer dúvidas, uma inteira reconfiguração da ordem do capital, sem eliminar (antes, recolocando-as em novos patamares e aprofundando-as) as suas contradições elementares e as sua dinâmica essencialmente exploradora: a reconfiguração então implementada e ainda em curso veio e vem exponenciando, no nível econômico, a sua tendência a concentrar polarizadamente riqueza e pauperismo, no nível social a barbarizar a interação humana, no nível político a acentuar a antidemocracia e, em relação ao meio ambiente, a sua destrutividade características do capitalismo contemporâneo, emergente a partir de meados dos anos 1970, que a retórica da "globalização" oculta e mistifica".
} 
que envolvem as classes sociais em presença numa dada quadra histórica. E todos esses vetores não só se transformam eles mesmos: as suas interações também se alteram no curso do desenvolvimento do modo de produção capitalista. (NETTO e BRAZ, 2011, p. 179-180).

No âmbito econômico, depois de um longo período de acúmulo de capital, no início da década de 1970, o fordismo e a fase keynesiana começou a dar sinais de crise; pois havia se esgotado o expansionismo do capital, "os anos dourados ${ }^{48 "}$ do capitalismo haviam chegado ao fim e as crises de 1974 e $1975^{49}$ contribuíram para alteração dos padrões de acumulação, dessa forma alterando o cenário social mundial, desembocando em um cenário de crise. ${ }^{50}$ (ANTUNES, 2009).

Os desdobramentos da crise se deram pela queda da taxa de lucro, pelo esgotamento do padrão de acumulação fordista - este modelo de produção gradativamente cede espaço para

\footnotetext{
${ }^{48}$ Segundo Netto e Braz (2011, p. 205) Entre o fim da Segunda Guerra Mundial e a passagem dos anos sessenta aos setenta, o capitalismo monopolista viveu uma fase única em sua história, fase que alguns economistas designam os "anos dourados" ou, ainda, as "três décadas gloriosas". Foram quase trinta anos em que o sistema apresentou resultados econômicos nunca vistos, e que não se repetiriam mais: as crises cíclicas não foram suprimidas ${ }^{35}$ mas seus impactos foram diminuídos pela regulação posta pela intervenção do Estado (em geral, sob a inspiração das idéias de Keynes) e, sobretudo as taxas de crescimento mostraram-se muito significativas.

${ }^{49}$ Segundo Netto e Braz (2011, p. 168) as crises no capitalismo são inevitáveis, essas acontecem a partir do momento que [...] o capitalista investe dinheiro para produzir mercadorias com o único objetivo de obter mais dinheiro do que investiu [...], quando as crises se instauram a mercadoria deixa de ser convertida em dinheiro. Segundo Netto (1996, p. 90) [...] O marco dos anos setenta não é um acidente cronológico; ao contrário; a visibilidade de novos processos se torna progressiva à medida que o capital monopolista se vê compelido a encontrar alternativas para a crise em que é engolfado naquela quadra. Com efeito, em 1974-1975 explode a "primeira recessão generalizada da economia capitalista internacional desde a Segunda Guerra Mundial" (Mandel, 1990: 9). Essa recessão monumental e o que se lhe seguiu pôs de manifesto um giro profundo na dinâmica comandada pelo capital: chegava ao fim o padrão de crescimento que, desde o segundo pós-guerra e por quase trinta anos (as "três décadas gloriosas" do capitalismo monopolista), sustentara, com as suas "ondas longas expansivas" o "pacto de classes" expresso no Walfare State (Perzworski, 1991). Emergia um novo padrão de crescimento que, operando por meio de "ondas longas recessivas" (Mandel, 1976), não só erodia as bases de toda a articulação sociopolítica até então vigente como, ainda, tornava exponenciais as contradições imanentes à lógica do capital, especialmente aquelas postas pela tendência à queda da taxa média de lucro e da superacumulação (Mandel, 1969, 1, V e 3, XIV). É para responder a este novo quadro que o capital monopolista se empenha, estrategicamente, numa complicada série de reajustes e reconversões que, deflagrando novas tensões e colisões, constrói a contextualidade em que surgem (e/ou se desenvolvem) autênticas transformações societárias.

${ }^{50}$ Segundo Antunes (2009, p. 29) [...] as condições de uma crise estrutural do capital, seus conteúdos destrutivos aparece em cena trazendo uma vingança, ativando o espectro de uma incontrolabilidade total, em uma forma que prefigura a autodestruição, tanto do sistema reprodutivo social como da humanidade geral. [...] Expansionista, desde seu microcosmo até sua conformação mais totalizante, mundializado, dada a expansão e abrangência do mercado global, destrutivo e, no limite, incontrolável, o sistema de metabolismo social do capital vem assumindo cada vez mais uma estruturação crítica profunda. Sua continuidade, vigência e expansão não podem mais ocorrer sem revelar uma crescente tendência de crise estrutural que atinge a totalidade de seu mecanismo. Ao contrário dos ciclos longos de expansão alternados com crises, presencia-se um depressed continuum que, diferentemente de um desenvolvimento autossustentado, exibe as características de uma crise cumulativa, endêmica, mais ou menos uma crise permanente e crônica, com a perspectiva de uma profunda crise estrutural. Por isso é crescente, no interior dos países capitalistas avançados, o desenvolvimento de mecanismos de "administração das crises", como parte especial da ação do capital e do Estado visando deslocar e transferir as suas maiores contradições atuais (idem: 597-598). Porém, a "disjunção radical" entre produção para as necessidades sociais e autorreprodução do capital não é mais algo remoto, mas uma realidade presente no capitalismo contemporâneo, com consequências as mais devastadoras para o futuro.
} 
uma nova forma de acumulação: o Toyotismo ${ }^{51}$ - hipertrofia da esfera financeira, maior concentração de capitais, crise do estado de bem-estar social e incremento acentuado das privatizações. Sendo assim, a crise do fordismo e do keynesianismo se torna somente uma expressão crítica dentro de um contexto bem mais complexo, originado das baixas taxas de acumulação do capital desencadeando uma baixa no crescimento da produtividade, ao cair à produtividade poucos foram os aumentos salariais que aconteceram além do alto índice de desemprego desembocando na "tendência decrescente do valor de uso das mercadorias". (ANTUNES, 2009).

[...] Essa crise estrutural fez com que, entre tantas outras consequências, fosse implementado um amplo processo de reestruturação do capital, com vistas a recuperação do seu ciclo produtivo [...] (ANTUNES, 2009, p. 38). Este complexo processo é denominado de reestruturação produtiva ${ }^{52}$, reestruturação essa que não transformou os pilares essenciais do modo de produção capitalista, portanto,

[...] Os anos 1980 foram marcados por uma revolução tecnológica e organizacional na produção, tratada na literatura disponível como reestruturação produtiva confirmando a assertiva mandeliana reforçada por Husson, 1999) da corrida tecnológica em busca do diferencial de produtividade do trabalho, como fonte dos superlucros (Mandel, 1982); pela mundialização da economia, diga-se, uma reformulação das estratégias empresariais e dos países no âmbito do mercado mundial de mercadorias e capitais, que implica um divisão do trabalho e um relação centro/periferia diferenciados do período anterior, combinado ao processo de financeirização (hipertrofia das operações financeiras); e pelo ajuste neoliberal, especialmente com um novo perfil das politicas econômicas e industriais desenvolvidas pelos Estados nacionais, bem como um novo padrão da relação Estado/sociedade civil, com fortes implicações para o desenvolvimento de políticas públicas, para a democracia e para o ambiente intelectual e moral. Estes são processos imbricados e interdependentes no seio da totalidade concreta, que é a sociedade burguesa contemporânea [...] (BEHRING, 2008, p. 33-34).

Desse modo, a "completa subordinação das necessidades humanas à reprodução do valor de troca - no interesse da autorrealização expansiva do capital - tem sido o traço mais notável do sistema de capital desde sua origem". (ANTUNES, 2009, p. 23). Sendo assim a acumulação flexível é uma "nova forma" do capitalismo que surge da "velha forma" do

\footnotetext{
${ }^{51}$ Segundo Antunes (1996, p. 79) [...] Diferentemente, tem-se um sistema que responde imediata e diretamente às demandas que são colocadas e que possui flexibilidade para alterar o processo produtivo de modo que não se opere com grandes estoques, mas com estoque mínimo; de modo que se tenha um sistema chamado de produção ou de acumulação flexível, que se adeque a essas alterações cotidianas do mercado. Enfim, um processo produtivo flexível que atenda esta ou aquela demanda com mais rapidez, sem aquela rigidez característica de produção em linha de montagem de tipo fordista [...].

52 [...] reorganização do capital e de seu sistema ideológico e político de dominação, cujos contornos mais evidentes foram o advento do neoliberalismo, com a privatização do estado, a desregulamentação dos direitos do trabalho e a desmontagem do setor estatal, da qual a era Thatcher-Reagan foi a expressão mais forte; a isso seguiu também um forte processo de reestruturação da produção e do trabalho, com vistas a dotar o capital do instrumental necessário para tentar repor os patamares de expansão anterior. (ANTUNES, 2009, p. 33).
} 
sistema, objetivando sempre o acúmulo de capital, segundo Húngaro (2012, p. 27) alguns elementos e relações invariantes são válidos para o modo de produção capitalista, estes delineados por Marx, 1) o capitalismo é orientado para o crescimento; 2) o crescimento em valores reais apoia-se na exploração do trabalho vivo na produção; 3) o capitalismo, é por necessidade, tecnológica e organizacionalmente dinâmico.

Com as significativas mudanças dos anos de 1980, profundas foram às mudanças no mundo do trabalho, chamadas por Antunes (1996) de metamorfoses do mundo do trabalho ${ }^{53}$, essas metamorfoses se caracterizam por trabalhadores cada vez mais qualificados e polivalentes, qualificados não no sentido amplo, mais sim específico daquilo que lhe é peculiar e designado, isso interferiu diretamente na subjetividade do trabalhador. Outra mudança característica desse período foi à redução da quantidade de operários na indústria, isso foi proveniente da reestruturação produtiva.

No que se referem às novas tecnologias as relações de trabalho consequentemente foram alteradas, sendo então exigido do trabalhador maior conhecimento técnico para manuseio das máquinas, portanto incremento técnico científico, tais exigências contribuíram para o aumento significativo do desemprego, se tornando crônico e estrutural, levando a afirmações sobre o "fim do trabalho" e "falecimento do sujeito operário". O que percebemos na verdade é o aumento de uma classe-que-vive-do-trabalho. (ANTUNES, 2009).

Embora heterogeneizado, complexificado e fragmentado, as possibilidades de uma efetiva emancipação humana ainda podem encontrar concretude e viabilidade social a partir das revoltas e rebeliões que se originam centralmente no mundo do trabalho e pelo trabalho. Esta não exclui nem suprime outras formas de rebeldia e contestação. Mas, vivendo numa sociedade que produz mercadorias, valores de troca, as revoltas do trabalho tem estatuto de centralidade. Todo o amplo leque de assalariados que compreendem o setor de serviços, os trabalhadores "terceirizados", os trabalhadores do mercado informal, os "trabalhadores domésticos", os desempregados, os subempregados etc., que padecem enormemente da desmontagem social operada pelo capitalismo em sua lógica destrutiva, pode (e devem) somar-se aos trabalhadores diretamente produtivos e por isso, atuando como

\footnotetext{
${ }^{53} \mathrm{O}$ mundo do trabalho viveu, como resultado das transformações e metamorfoses em curso nas últimas décadas, particularmente nos países capitalistas mais avançados, com repercussões significativas nos países do Terceiro Mundo dotados de uma industrialização intermediária, um processo múltiplo: de um lado verificou-se uma desproletarização do trabalho industrial, fabril, nos países de capitalismo avançado. Em outras palavras, houve uma diminuição da classe operária industrial tradicional. Mas, paralelamente, efetivou-se uma significativa subproletarização do trabalho, decorrência das formas diversas de trabalho parcial, precário, terceirizado, subcontratado, vinculado à economia informal, ao setor de serviços etc. Verificou-se, portanto, uma significativa heterogeneização, complexificação e fragmentação do trabalho. [...] Efetivou-se também uma expressiva "terceirização" do trabalho em diversos setores produtivos, bem como uma enorme ampliação do assalariamento do setor de serviços; verificou-se igualmente uma significativa heterogeneização do trabalho, expressa pela crescente incorporação do contingente feminino no mundo operário. Em síntese: houve desproletarização do trabalho manual, industrial e fabril; heterogeneização, subproletarização e precarização do trabalho. Diminuição do operariado industrial tradicional e aumento da classe-que-vive-do-trabalho. (ANTUNES, 2009, p. 205-207, Grifos do autor).
} 
classe, constituem-se no segmento social dotado de maior potencialidades anticapitalistas. Em síntese, a luta da classe-que-vive-do-trabalho é central quando se trata de transformações que caminham em sentido contrário à lógica da acumulação do capital e do sistema produtor de mercadorias. Outras modalidades de luta social (como ecológica, a feminista, a dos negros, dos homossexuais, dos jovens, etc.) são como o mundo contemporâneo tem mostrado em abundância, de grande significado, na busca de uma individualidade e de uma sociabilidade dotada de sentido. Mas, quando o eixo é a resistência e o confronto a lógica do capital e a sociedade produtora de mercadorias, o centro desta ação encontra maior radicalidade quando se desenvolve e se amplia no interior das classes trabalhadoras, ainda que reconhecendo que esta empreitada é muito mais complexa e difícil do que no passado, quando a sua fragmentação e heterogeneidade não tinham a intensidade encontrada no período recente. (ANTUNES, 2006, p. 94-95).

\title{
1.2.1.1.2 - O Social
}

\begin{abstract}
As transformações no nível social não se reduzem, obviamente, às alterações na estrutura de classes - ainda que elas se conectem e nelas repercutam. Vinculadas às profundas modificações no perfil demográfico das populações (em função seja das taxas de crescimento, seja do aumento do aumento da média de vida), à expansão urbana (em meados da década de oitenta, $42 \%$ da população estava nas cidades ${ }^{17}$ ), ao crescimento das atividades de serviços (o "terciário" de C. Clark), à difusão da educação formal (inclusive a superior: nos anos setenta, o número de universidades no mundo praticamente dobrou) e aos novos circuitos da comunicação social (conduzindo ao ápice a indústria cultural que a "escola de Frankfurt" analisou e criticou) - vinculadas a esses e a outros vetores, as transformações no nível social da ordem tardo-burguesa revelam-se notáveis. Rebatendo na estrutura da família (sobre o que Hobsbawm, 1995: 314-315, fornece dados importantes) e muito ligadas às transformações de natureza cultural, a que se aludirá à frente, elas convulsionam os padrões de socialidade. (NETTO, 1996, p. 95).
\end{abstract}

As mudanças sociais foram muitas e rápidas. Segundo Hobsbawm (1995) a Revolução Social aconteceu principalmente por três fatores: alteração da organização da família da sociedade burguesa, em que as mulheres deixam de trabalhar dentro de casa; alteração do cenário político e aumento dos desprotegidos sociais. Outro fator que influiu nas mudanças sociais foi a morte do campesinato, além de outros, como: [...] O grande aumento da urbanização, o crescimento da atividade de serviços, a difusão da educação formal, a mudança no perfil demográfico das populações e a individualização do lazer são fenômenos que servem de exemplo dessas mudanças [...] (HÚNGARO, 2008, p. 129).

O papel da mulher na sociedade enquanto trabalhadora não é novidade, novidade se torna as mulheres casadas trabalharem, [...] Em 1940, as mulheres casadas que viviam com os maridos e trabalhavam por salário somavam menos de $14 \%$ do total da população feminina dos EUA. Em 1980, eram mais da metade: a porcentagem quase duplicou entre 1950 e 1970" (HOBSBAWM, 1995, p. 304), essa mudanças acarretaram, com o tempo, uma significativa importância para a mulher, dando forma ao feminismo, em que lutas por igualdade de direitos passaram a tomar forma e serem notadas socialmente. 
No contexto político os jovens dominaram o cenário, [...] Fruto do crescimento da difusão da educação formal, mais especificamente, da educação formal em nível universitário, o mundo assistiu, a partir dos anos 60, a uma forte participação dos jovens nos acontecimentos sociais. [...] (HÚNGARO, 2008, p. 130).

\begin{abstract}
Essas massas de rapazes e moças e seus professores, contadas aos milhões ou pelo menos centenas de milhares em todos os Estados, a não ser nos muito pequenos e excepcionalmente atrasados, e concentradas em campi ou 'cidades universitárias' grandes e muitas vezes isolados, constituíam um novo fator na cultura e na política. (HOBSBAWM, 1995, p. 292, Grifos do autor).
\end{abstract}

Outro fator relevante para Hobsbawm (1995) são os desprotegidos sociais, esses passam a sofrer com os retrocessos das políticas sociais e com a perda de direitos, sendo as ações focalizadas no estado, [...] Somos testemunhas do crescimento exorbitante do Terceiro Setor e do voluntariado, exercendo funções que eram antes do Estado e da transformação social dos direitos sociais ${ }^{32}$ em simples mercadorias. (HÚNGARO, 2012, p. 34).

\begin{abstract}
Enfim, cabe referir a existência - decisivamente influenciada pelo caráter acentuadamente concentrador (de renda, riqueza e propriedade), na atividade econômica, e excludente e restritivo, no âmbito das garantias sociais, do capitalismo tardio que se quer "flexibilizar" - de uma miríade de segmentos desprotegidos. Tais segmentos compreendem universos heterogêneos, desde aposentados com pensões miseráveis, crianças e adolescentes sem qualquer cobertura social, minorias e/ou migrantes, doentes estigmatizados (recorde-se a situação de aidéticos pobres), até trabalhadores expulsos do mercado de trabalho (formal e informal). $\mathrm{O}$ que singulariza tais segmentos não é o fato de encarnarem uma qualquer "nova pobreza" ou de marcarem a emergência de "subclasses", nem o de não serem identificados com o antigo lumpem ${ }^{19}$; o que peculiariza boa parcela desses segmentos é que, situados nas bordas da "sociedade oficial", eles se vêem e são vistos como uma "não-sociedade" ou uma "contra-sociedade" - e assim interatuam com a ordem. (NETTO, 1996, p. 96).
\end{abstract}

Dessa maneira a revolução social se torna evidente que a revolução social não foi um fato isolado, e sim mudanças que estão inter-relacionadas entre si, o que exige uma mudança de forma sistêmica e absoluta e não como tem acontecido, através de reformas, em que a ordem social é imposta de forma natural ou herdada.

\title{
1.2.1.1.3 - O Cultural
}

No âmbito da cultura duas foram as alterações mais notórias: a mudança no seio familiar e a criação de uma indústria do entretenimento, a Indústria Cultural. Segundo Hobsbawm (1995) as mudanças familiares impactaram de maneira imensurável a cultura, 
houveram mudanças nas condutas sexuais, na parceria, na procriação; a legalização do aborto, da pílula anticoncepcional e do divórcio em alguns países foram cruciais para significativas mudanças. [...] Oficialmente, essa foi uma era de extraordinária liberalização tanto para os heterossexuais (isto é sobretudo para as mulheres, que gozavam de muito menos liberdade que os homens) quanto para os homossexuais, além de outras formas de dissidência culturalsexual. (Ibidem, p. 316).

No que se refere à indústria cultural passamos a notar que a vida social se tornou mercantilizada e a lógica da imediaticidade ganha forma em relação à realidade, influenciando diretamente na cultura do consumo, na ditadura dos hábitos e das modas. Sendo assim

\begin{abstract}
A dinâmica cultural do capitalismo tardio que se vem "flexibilizando" está parametrada por dois vetores: a translação da lógica do capital para todos os processos do espaço cultural (produção, divulgação, consumo) e o desenvolvimento de formas culturais socializáveis pelos meios eletrônicos (a televisão, o vídeo, a chamada multimídia). O traço mais notável dessa cultura é que ela incorpora as características típicas da mercadoria - sua obsolênscia programada, sua fungibilidade, sua imediaticidade reificante. Mesmo que a sociedade tardo-burguesa esteja longe de ser uma "sociedade de consumo", a sociedade que nela hoje se afirma é uma cultura do consumo (Featherstone, 1995); ela cria a "sensibilidade consumidora" que se abre à devoração indiscriminada e equalizadora de bens materiais e ideais - e, nela, a própria distinção entre realidade e signos se esfuma: numa semiologização do real, o signo é o real. A imediaticidade da vida social planetariamente mercantilizada ganha o estatuto da realidade - e, não por acaso, a distinção clássica entre aparência e essência é desqualificada. (NETTO, 1996, p. 97, Grifos do autor).
\end{abstract}

A cultura do efêmero se difunde de tal modo que o ter se torna muito mais importante do que o ser, anulando o ser social, reforçando veementemente a alienação, a reificação e o individualismo, tornando cada vez mais forte concepção mercadológica por todas as esferas de produção e reprodução da vida social. [...] O velho vocabulário moral de direitos e deveres, pecado e virtude, sacrifício, consciência, prêmios e castigos não mais podia ser traduzido na nova linguagem de satisfação de desejos. [...] (HOBSBAWM, 1995, p. 331).

Ao mesmo tempo, o chamado movimento pós-modernista atacou as bases analíticas da filosofia moderna [...] (HÚNGARO, 2008, p. 131), afirmando ser a totalidade irracional, os "jogos de linguagem” os argumentos para as diversas ciências e que não há uma ciência verdadeira, confirmando que [...] o que se poderia chamar de movimento pós-moderno é muito heterogêneo [...] (NETTO, 1996, p. 97).

Do ponto de vista de seus fundamentos epistemológicos e teóricos, porém, o movimento é funcional à lógica cultural do estágio contemporâneo do capitalismo 
(Jameson, 1984): é o tanto ao sancionar acriticamente as expressões culturais da ordem tardo-burguesa quanto ao romper com os vetores críticos da Modernidade (cuja racionalidade os pós-modernos reduzem, abstrata e arbitrariamente, à dimensão instrumental, abrindo a via aos mais diversos irracionalismos). Mas, por essa mesma funcionalidade, a retórica pós-moderna não é uma intencional mistificação elaborada por moedeiros falsos da academia e publicitada pela mídia a serviço do grande capital. [...] o que os pós-modernos tomam como tarefa "criadora" (ou segundo alguns, "desconstrutora") é a própria funcionalidade ídeo-social da mercadoria e do capitalismo. (NETTO, 1996, pp. 97-98).

A dissolução de classe e a constituição das novas identidades culturais contribuíram para a disseminação da "cultura global", essa se movimenta a partir da produção, divulgação e consumo, reforçando a idéia global gerando um universo particular e singular, tudo isso em prol do consumo. [...] Nessa cultura, parece vigorar a máxima segundo a qual "não há sociedade, só indivíduos”. (NETTO, 1996, p. 98).

\subsubsection{4 - O Político}

Todas essas mudanças nos âmbitos econômico, social e cultural formam uma totalidade mutuamente determinada com as transformações políticas ocorridas no mundo contemporâneo. São elas: o fortalecimento de uma oligarquia financeira transnacional, uma descaracterização da clássica oposição capital x trabalho, um enfraquecimento do movimento operário (já que cresce cada vez mais o desemprego em função das novas tecnologias), isso tudo acompanhado pelo fortalecimento dos chamados movimentos sociais (movimento dos sem-terra, movimento dos sem-teto, movimento dos aposentados, movimento negro, movimento gay, entre outros). Além desses aspectos, temos ainda a crise de ordenamentos político-sociais, fundamentais para o fortalecimento dos direitos sociais, alternativos ao capitalismo: o socialismo e a social-democracia. (HÚNGARO, 2008, p. 133-134).

O descentramento da política influencia diretamente na manutenção e ampliação dos

direitos sociais, sendo as contradições sociais negadas, dessa maneira acentuando a tecnocracia, portanto, [...] A política não pretende mais 'mudar a vida' e os parlamentos perdem seu papel de representação das reivindicações sociais. [...] Os atores deixam de ser sociais e voltam-se para si mesmos, para a busca narcisista da sua identidade [...]. (EVANGELISTA, 2007, p. 94-95).

Dessa forma, presenciamos a planetarização do capitalismo. Com esse "redesdobramento" econômico, percebe-se o "não lugar" do Estado na condução política e econômica atual. Nada mais atual que a formulação de Marx e Engels consignada no Manifesto Comunista de que "O executivo do Estado é o comitê para gerir os negócios da burguesia", desde que acrescentando ao final "burguesia financeiro-especulativa". O Estado deixa de ser o "poder" central, passa-se, então, a um poder difundido por toda a sociedade civil. 


\title{
1.2.1.1.5 - A Ciência
}

$\mathrm{Na}$ ciência a tecnocracia toma forma, no que diz respeito a modernidade os diálogos e debates no âmbito acadêmico se constituíam a partir da saturação de determinações o objeto, já no que se refere ao contexto do movimento da pós-modernidade as constantes afirmações sobre a irracionalidade da totalidade afetou diretamente o desvelar da realidade, se tornando cada vez mais nítido a negação das contradições do real e a junção entre aparência e essência como sinônimos.

\begin{abstract}
Ainda no âmbito cultural, como não poderia deixar de ser, mudanças significativas foram sentidas no campo da ciência. As universidades - importantes instituições produtoras e difusoras de conhecimento - foram integradas ao pensamento da decadência burguesa. Toda e qualquer compreensão de uma ciência comprometida com transformação social foi abandonada pelos gestores e tecnocratas da pesquisa, funcionários das universidades. (PATRIARCA, 2012, p. 68).
\end{abstract}

Com a transformação social pautada na tecnocracia, o pensamento irracionalista passa a dominar o contexto, justamente por ser absolutamente funcional ao capitalismo, [...] Então, os principais temas da racionalidade moderna - ciência, verdade, progresso, revolução, felicidade, etc. - darão lugar à valorização do fragmentário, do microscópico, do singular, do efêmero, do imaginário, dentre outros. (EVANGELISTA, 1992, p. 24).

Esse "novo irracionalismo" descartou a racionalidade como fundamento metodológico cedendo espaço a desreferencialização do real; dessubstancialização do sujeito e descentramento da política. [...] Para além do irracionalismo, percebemos que a pósmodernidade opera também com a instrumentalização da razão [...] (PATRIARCA, 2012, p. 68), essa instrumentalização acontece a partir do momento que o conhecimento somente é utilizado se for útil ao capital, portanto, se tornando mercadoria.

\footnotetext{
Estas transformações não sinalizam um processo evolutivo "natural" da sociedade burguesa. Constituem, a partir de limites e possibilidades objetivos, uma resposta estratégica dos núcleos dirigentes capitalistas à problematização da ordem do capital, avolumada nos anos 1960 - da qual a explosão de maio de 1968 foi apenas um indicador, ainda que grandemente expressivo - e adensada na entrada dos anos 1970. (NETTO, 2010, p. 257).
} 


\title{
1.2.2 - A Miséria da Razão ${ }^{54}$
}

\begin{abstract}
A "miséria da razão" - seu empobrecimento e extrema formalização - desemboca num agnosticismo que oculta a essência do real. Enquanto o racionalismo da época clássica propunha-se conquistar terrenos cada vez mais amplos para e por meio da razão humana, o miserável racionalismo da decadência preocupa-se principalmente em estabelecer "limites" para o conhecimento, enquanto a filosofia clássica era preponderantemente ontológica, preocupada com o conteúdo objetivo do mundo, o agnosticismo decadente pretende-se simples epistemologia, simples análise formal dos "limites do conhecimento". A razão, em suma, deixa de ser imagem da legalidade objetiva da totalidade real, passando a confundir-se com as regras formais que manipulam "dados" arbitrariamente extraídos daquela totalidade objetiva. O paralelismo entre esse empobrecimento da razão e o esvaziamento da práxis na atividade burocrática não é causal. A "miséria da razão" é a expressão teórica deformada e deformante - do mundo burocratizado do capitalismo. (COUTINHO, 2010, p. 51).
\end{abstract}

A burocratização do capitalismo desempenha um destacado papel na práxis técnica (COUTINHO, 2010, p. 52), aplicando uma racionalidade formalista à vida social, fetichizando as relações humanas. Sendo assim, a práxis burocrática passa a fragmentar a racionalidade, limitando-a as determinações do capitalismo.

\begin{abstract}
Concretamente, isso significa substituir a pesquisa da essência ontológica do real (inacessível à racionalidade burocrática) pela reprodução imediata da aparência. Desse modo, tudo o que é objeto da razão dialética - e que nela, e só nela, pode ser elevado à consciência - é declarado como "metafísica", "falso problema", "resíduo irracional"; a destruição e a miséria da razão desembocam no mesmo ponto. (COUTINHO, 2010, p. 53).
\end{abstract}

A partir da atividade burocrática as contradições passam a ser suprimidas pelo formalismo, tornando o conhecimento e a racionalidade constantes, portanto [...] a redução do diverso ao idêntico, do variável ao constante, do contraditório ao homogêneo [...] (COUTINHO, 2010, p. 54) contribui para a formalização não só do real, mais da racionalidade, confirmando [...] o abandono à irratio dos problemas conteudísticos, ou seja, da gênese histórica e do sentido humano dos processos analisados. (COUTINHO, 2010, p. 54).

\footnotetext{
${ }^{54}$ Segundo Coutinho (2010, p. 65) [...] Enquanto na primeira época da decadência predominou o irracionalismo, a partir de 1848 - com a estabilização do capitalismo, expressa no grande progresso material e técnico da sociedade burguesa e no refluxo da onda revolucionária - as formas vitais ligadas a "segurança" começam a dominar a intelectualidade, impondo transformações ideológicas. Em termos filosóficos, essa sensação de segurança expressa na substituição da "metafísica negativista” (própria da filosofia clássica alemã) pelo "espírito positivo" radicalmente agnóstico de Comte. Na literatura, o novo período é assinalado pela recusa da arte em figurar comportamentos típicos, superiores à média cotidiana; o naturalismo (equiparando arbitrariamente romantismo e realismo autêntico) limita-se a descrever de modo "positivo" e pseudocientífico a superfície alienada da vida. (Que se recorde o combate de Taine e Zola contra o pretenso romantismo de Balzac e Stendhal). Durante essa época o irracionalismo torna-se marginal; a filosofia oficial converte-se quase inteiramente ao positivismo, ou no sentido comteano ou naquele neokantiano.
} 
A própria atividade humana, a práxis social em todas as suas determinações, vai sendo progressivamente afastada do domínio da racionalidade. É assim que Comte, deturpando e fetichizando um problema real (a primazia ontológica da sociedade sobre o indivíduo), afirma que, para o espírito positivista, "o homem propriamente dito não existe, não pode existir senão a Humanidade.” (COUTINHO, 2010, p. 55).

Segundo Coutinho (2010) cada autor assume uma tendência agnóstica de acordo com a evolução do capitalismo, tendendo a acentuação, implicando assim a aplicação de regras formais, portanto burocratizando o intelecto. Portanto,

\begin{abstract}
A racionalidade limita-se a estabelecer as regras formais, ou sintaxe lógica, que organizam o discurso, constatando assim se determinada proposição possui ou não "validade". A validade é determinada pela relação da proposição com o sistema formal da linguagem, abandonando-se explicitamente o conceito de verdade, isto é, a correspondência entre a proposição ou o "sistema" e a realidade exterior. (A busca dessa correspondência é considerada "metafísica" e irracional.) O conhecimento - a razão - reduz-se a uma pura forma [...]. (COUTINHO, 2010, p. 57).
\end{abstract}

A redução à pura forma gera a manipulação da vida privada, [...] a manipulação da vida privada não passa de uma ampliação a novas esferas daquilo que chamamos de racionalidade burocrática [...] (COUTINHO, 2010, p.71), dessa maneira acentuam-se o controle e a padronização humana, característica explicita da alienação capitalista. Adiante analisaremos as expressões reais da miséria da razão e suas incidências no contexto da pósgraduação. 


\title{
CAPÍtUlO II
}

\section{O CONTEXTO E AS NUANCES DO PRODUTIVISMO ENQUANTO EXPRESSÃO DA MISÉRIA DA RAZÃo}

\author{
Neste segundo capítulo iremos estabelecer uma linha de compreensão das \\ determinações e condicionamentos em torno da expressão real da miséria da razão e do \\ capitalismo contemporâneo (MANDEL, 1982; BEHRING, 2008; ANTUNES, 2009; \\ COUTINHO, 2010; NETTO, BRAZ, 2011) pontuando as circunstâncias mais gerais da \\ política de pós-graduação brasileira (ÁVILA, 2008; SACARDO; 2012; PATRIARCA, 2012), \\ por uma breve análise do Programa Nacional de Pós-Graduação (PNPG 2011-2020).
}

\section{1 - A miséria da razão e o capitalismo contemporâneo ${ }^{55}$}

As correntes diretamente ligadas à miséria da razão ${ }^{56}$ estão estritamente ligadas a burocratização da práxis sob o capitalismo, segundo Coutinho (2010) esse tipo de racionalidade está diretamente ligada a técnica ${ }^{57}$, a dominação da natureza. Nesse contexto de

\footnotetext{
${ }^{55}$ Partiremos da leitura de Netto e Braz (2011, p. 221) “A configuração do capitalismo que designamos como contemporânea inicia-se nos anos setenta do século XX e continua a ter no centro da sua dinâmica o protagonismo dos monopólios - vale dizer, o capitalismo contemporâneo constitui a terceira fase do estágio imperialista. Entretanto, as alterações experimentadas pela economia que o capital monopolista comanda são de tal ordem que, para caracterizá-la, até mesmo já se propôs a expressão do novo imperialismo (Harvey). (Grifos dos autores).

${ }^{56}$ Rodrigues (2006, p. 182) apresenta relevantes considerações sobre a 'miséria da razão'/‘destruição da razão': "Sob um claro referencial lukacsiano, Coutinho (1972) demonstra com precisão o denominador comum entre a “destruição da Razão" e a "miséria da Razão". Visivelmente opostos do ponto de vista filosófico, irracionalismo e racionalismo formal têm uma atitude similar em face do problema da Razão. Ambas negam que a totalidade do real possa ser objeto de uma apreensão racional e operando com um conceito limitado da Razão - reduzindo-a a mera intelecção, a um conjunto de regras formais subjetivas - tornam irracionais todos os momentos significativos da vida social ${ }^{204}$. Irracionalismo e racionalismo formal correspondem, portanto, a variações de um pensamento fetichizado, isto é, um pensamento que, incapaz de apreender a totalidade concreta, preso a imediaticidade dos fatos, se fixa no dilaceramento histórico da vida social provocado pela alienação capitalista. Sua cisão em duas orientações filosóficas aparentemente antagônicas lembra as duas cabeças de Janus, mas a bipartição das faces não anula a unidade do corpo: tanto a perspectiva da destruição quanto a da miséria da Razão podem ser tomadas como posições teórico-ideológicas conservadoras. Como variantes de uma "fillosofia da decadência"205, ambas operam um abandono mais ou menos integral das conquistas filosóficas empreendidas por um pensamento burguês revolucionário ${ }^{206}$ que, indo dos renascentistas a Hegel, orientava-se no sentido da elaboração de uma racionalidade humanista e dialética ${ }^{207, "}$.

${ }^{57}$ Segundo Mandel (1982, p. 269, Grifos dos autores) " Sob crescente socialização objetiva do trabalho, mesmo com a produção generalizada de mercadorias, uma divisão cada vez maior de trabalho só pode ser efetivada se as tendências à centralização predominarem sobre as tendências à atomização. No capitalismo, esse processo de centralização tem caráter duplo: é técnico e é econômico. Tecnicamente, uma divisão crescente do trabalho só pode combinar-se com uma socialização crescente e objetiva do trabalho por meio de uma ampliação das funções intermediárias: daí a expansão sem precedentes dos setores de comércio, transporte e serviços em geral. Economicamente, o processo de centralização só pode manifestar-se por meio de uma centralização crescente do
} 
deformação da expressão teórica, o capitalismo contemporâneo influencia de tal maneira que a miséria da razão se torna [...] a expressão teórica - deformada e deformante - do mundo burocratizado do capitalismo. (COUTINHO, 2010, p. 51).

Para que a credibilidade acerca da miséria da razão ${ }^{58}$ se instaurasse, a eficácia formal e a estabilidade foram utilizadas para organizar a "ideologia'59, de modo que as "normas" e as regras socialmente impostas passam a ser sinônimos de 'segurança', essa [...] liga-se estreitamente à limitação imposta pela economia capitalista à plena expansão da personalidade humana. [...] (COUTINHO, 2010, p. 64).

Portanto, percebe-se facilmente a relação direta entre burocracia e "segurança", ou seja, o modo pelo qual uma vida "segura" submete-se aos princípios do formalismo pseudorracional e aos valores burocráticos da eficácia "profissional"; a "segurança", assim, conforma-se à identificação entre personalidade individual e função desempenhada na divisão do trabalho, identificação própria da cultura capitalista. A relação entre "segurança" e conformismo foi observada por Max Weber: "O ingresso num cargo, inclusive na economia privada, é considerado como a aceitação de uma obrigação específica de administração fiel em troca de uma existência segura". "Racional", portanto, passa a ser a práxis, moral fundada no conformismo e na aceitação de "regras" formais. (Ibidem, p. 64, Grifos do autor).

As regras formais influenciam no agnosticismo, passando a afastar da vida social as questões teóricas fundamentais para a reflexão crítica, desembocando na tecnocracia ${ }^{60}$, tornando a ciência cada vez mais especializada e os intelectuais cada vez mais burocratizados, portanto, [...] É assim que, em perfeita conformidade com a divisão do trabalho, própria do

capital, entre outras, sob a forma de uma integração vertical de grandes empresas, firmas multinacionais e conglomerados."

${ }^{58}$ Quanto à 'segurança' no contexto da miséria da razão Coutinho (2010, p. 65) afirma que; "O temor de Comte ao "progresso anárquico" (às revoluções), com a consequente defesa da primazia da "ordem"; a afirmação de Durkheim segundo a qual o "espírito de disciplina" é a condição básica da vida social; a subordinação do progresso a "estruturas" imutáveis na obre de Lévi-Strauss: temos aqui três elaborações ideológicas, em épocas diversas, do mesmo sentimento pequeno-burguês da "segurança" manipulada como valor supremo da vida".

59 A ideologia no contexto da miséria da razão está relacionada com "[...] a vulgar apologética burguesa que negava o caráter contraditório da objetividade econômica do capitalismo (no que rompia decisivamente com a tradição progressista), afirmando sua homogeneidade, sua tendência ao equilíbrio e ao progresso linear. Com a acentuação das contradições capitalistas, essa segunda tendência orienta-se para o agnosticismo, refugiando-se num formalismo vazio e convertendo-se em positivismo, ou seja, passa a estabelecer "limites" à compreensão racional da realidade". (COUTINHO, 2010, p. 45).

${ }^{60}$ Segundo Ferreira Jr. e Bittar (2008, p. 351-352) "Os tecnocratas são os experts (técnicos) responsáveis pela aplicação das novas tecnologias na administração do poder de Estado, ou seja, das técnicas empregadas no âmbito das ações governamentais com o objetivo de se alcançar a eficiência na racionalização dos recursos financeiros aplicados nos vários setores das políticas estatais. "O governo dos tecnocratas" é denominado pela ciência política de "tecnocracia". A expressão tecnocracia foi "lançada nos Estados Unidos quando da Primeira Guerra Mundial (1914-1918) para designar governo dos técnicos, difundindo-se na época do New Deal”. Em síntese: os tecnocratas são os "managers ou técnicos de categoria superior, colocados à frente de grandes empresas ou de departamentos oficiais do Estado" (Sousa et al., 1998, p. 515-516). Já Bresser Pereira (1982, p. 86) afirma que "o conceito de tecnoburocracia decorre do de técnico. Tecnoburocracia é o governo dos técnicos. É o sistema em que o poder está nas mãos dos técnicos, sejam eles economistas, engenheiros, administradores públicos e privados ou militares profissionais. Colocada nesses termos, tecnocracia seria um tipo de oligarquia: a oligarquia dos técnicos. Opõe-se, portanto, a outros sistemas políticos, particularmente à democracia"”. 
capitalismo evoluído, essa camada de intelectuais burocratizados que formam parte do aparelho de estado (...) torna-se depositária da filosofia nova ${ }^{38}$. (LUKÁCS apud COUTINHO, 2010, p. 65).

Conforme apresentado no primeiro capítulo, o primeiro período da decadência ideológica correspondeu ao irracionalismo (momento de instabilidade do capitalismo), já na segunda fase da decadência ideológica (momento de estabilização do capital) inicia-se a fase de 'segurança' referente à intelectualidade ${ }^{61}$, acarretando algumas transformações ideológicas, no que diz respeito à filosofia [...] essa sensação de segurança expressa-se na substituição da "metafísica negativista" (própria da filosofia clássica alemã) pelo "espírito positivo" radicalmente agnóstico de Comte. (COUTINHO, 2010, p. 65, Grifos do autor). Essa fase de estabilidade apresenta problemas na virada do século, momento em que o capitalismo ${ }^{62}$ apresenta suas bases e condições precárias.

\begin{abstract}
A esse período "explosivo", marcado por guerras e revoluções, corresponde o renascimento de um individualismo profundamente antissocial; a angústia torna-se novamente o modo imediato de reação à realidade conturbada. Pensadores e artistas sinceros começam a denunciar abertamente a falsa segurança, a desumanidade objetiva da vida burguesa. Em alguns casos essa denúncia parte da mobilização intelectual dos mais autênticos valores da tradição progressista, do grande humanismo clássico, que se revela assim uma ponte entre a consciência democrática e a consciência socialista ${ }^{39} .{ }^{63}$ (COUTINHO, 2010, p. 66, Grifos do autor).
\end{abstract}

\footnotetext{
${ }^{61}$ Segundo Coutinho (2010, p. 100) “O intelecto, incapaz de compreender a realidade contraditória do início do século, refugia-se nos exíguos da "linguagem subjetiva", convertendo o mundo no "mundo" do indivíduo isolado. A relativa estabilização do capitalismo contemporâneo, a generalização social dos processos manipulatórios, alimenta a ilusão de que a contrariedade foi eliminada do real (ou pode ser tratada como simples "resíduo"). Nessas condições, a corrente positivista volta a apresentar pretensões "ontológicas": o conjunto de regras formais que os neopositivistas lógicos situavam no sujeito aparece agora, no estruturalismo como uma "coisa" autônoma, superior e independente dos homens".

${ }^{62}$ Para que possamos compreender o movimento do capitalismo, é de estrema relevância compreendermos o capital, na leitura de Netto e Braz (2011, p. 179) uma breve apresentação conceitual nos ajuda nessa diferenciação: "Capital, [...], é relação social e as relações sociais são, antes de mais, relações de essência histórica: são mutáveis, transformáveis. Resultantes das ação dos homens, exercem sobre eles pressões de constrangimentos, acarretam efeitos e consequências que independem da sua vontade; mas, igualmente, são alteráveis e alteradas pela vontade coletiva e organizada das classes sociais - nas palavras de Marx, "os homens fazem sua própria história, mas não a fazem como querem; não a fazem sob circunstâncias de sua escolha e sim sob aquelas com que se defrontam diretamente, legadas e transmitidas pelo passado" (Marx, 1968:17). Também assinalamos o caráter processual do capital, que é valor que precisa valorizar-se, se expandir-se - capital é movimento, dinamizado pelas suas contradições. Por essas razões (entre outras), o capitalismo não só é história, mas tem a sua própria história: produto de transformações operadas ainda no seio da ordem feudal, a partir do momento que se impõe instaurou mecanismos e dispositivos de desenvolvimento que lhe são peculiares." (Grifos dos autores).

${ }^{63}$ Segundo Coutinho (2010, p. 66) "Esse movimento humanista é diretamente responsável pelo nascimento de excelentes obras de arte realistas (Romain Rolland, Roger Martin du Gard, Bernard Shaw, Heinrich e Tomas Mann, Theodore Dreiser etc.). No plano conceitual, todavia, ele é mais limitado. Produziu belíssimos estudos sobre o humanismo clássico (tais como os de Werner Jaerger sobre a Grécia, ou os de Thomas Mann sobre Goethe), mas revelou-se estéril no campo específico da filosofia. Nesse terreno, mesmo seus mais lúcidos representantes, revelavam-se desarmados diante da filosofia da decadência; basta lembrar aqui a tentativa equivocada e arbitrária - de Heinrich e de Thomas Mann no sentido de transformar Nietzsche e Schopenhauer em filósofos humanistas.
} 
Essas "novas filosofias" passam a expressar soluções niilistas para o contexto de crise, Lukács (2010) nos apresenta algumas exceções, afirmando existir verdadeiros realistas e denuncia o pessimismo que passa a envolver o homem e a teoria da história. As condições reais foram agravadas com o fim da segunda guerra mundial e início da guerra fria, pois, as constantes ameaças de destruição da humanidade intensificaram essa angústia acerca do pessimismo, acarretando significativas transformações, sendo essas refletidas na filosofia, na arte, na literatura, na cultura, na economia.

Lukács apud Coutinho (2010, p. 67) aponta as duas principais características dessa transformação econômica: 1) “[...] nos oitenta anos seguintes [à morte de Marx], todo o terreno do consumo foi dominado pelo processo capitalista [...]”, o autor afirma que incialmente esse processo dominava somente a produção; posteriormente o sistema de manipulação se estendeu para a sociedade e para a política, isso se deve as necessidades econômicas que foram criadas ao longo do período. 2) “[...] nessa nova fase do capitalismo, a exploração da classe operária volta-se cada vez mais intensamente da exploração mediante a mais-valia absoluta para uma exploração operada através da mais-valia relativa [...]", significando um aumento na exploração e do nível de vida do trabalhador.

Com o aumento do nível de vida de trabalhador é possível que aumente também a produção sem o risco de crises (superprodução), a este período de 'estabilidade' do capitalismo $^{64}$ Netto e Braz (2011) nomeiam de anos dourados ou três décadas gloriosas do modo de produção capitalista, sendo este o segundo estágio de três fases do imperialismo ${ }^{65}$ do modo de produção capitalista.

\footnotetext{
${ }^{64}$ Segundo Netto e Braz (2011) o capitalismo constitui-se por três estágios: $1^{\circ}$ o estágio mercantil (ou comercial); $2^{\circ}$ o estágio concorrencial (ou liberal) e $3^{\circ}$ o estágio imperialista (ou monopolista). $1^{\circ}-\mathrm{O}$ estágio mercantil teve início no século XVI e findou-se na primeira metade do século XVIII, caracterizou-se, principalmente, por estreitar relações entre povos e regiões que até então não mantinham relações. $2^{\circ}$ - $\mathrm{O}$ estágio concorrencial teve início na segunda metade do século XVIII e findou-se no último terço do século XIX, caracterizou-se, principalmente, pelo estabelecimento de uma economia mundial. $3^{\circ}$ - $\mathrm{O}$ estágio imperialista teve início nos últimos três decênios do século XIX e se prolonga pelo século XXI, caracteriza-se por três fases: Clássica, anos dourados e capitalismo contemporâneo, adiante apresentaremos mais elementos dessas duas últimas fases.

${ }^{65}$ Segundo Netto e Braz (2011, p. 198-202) "O imperialismo é um estágio de desenvolvimento do capitalismo; por isso mesmo, as leis (tendências) que comandam a dinâmica desse modo de produção continuam operando nesse estágio. No entanto, fazem-no sob condições novas e dessas novas condições, que modificam a operação daquelas leis, decorrem processos e fenômenos antes inexistentes (ou que antes não tinham a relevância que, com o imperialismo, passam a ter). [...] Na sua trajetória de pouco mais de um século, o imperialismo sofreu significativas transformações. Na história desse estágio do modo de produção capitalista, podem-se distinguir pelo menos três fases: a fase "clássica" que, segundo Mandel, vai de 1890 a 1940, os "anos dourados", do fim da Segunda Guerra Mundial até a entrada dos anos setenta32 e o capitalismo contemporâneo, de meados dos anos setenta aos dias atuais. Se, como em toda periodização histórica, essa cronologia é puramente indicativa, o que nos importa sublinhar é que, malgrado todas as transformações que assinalaremos, todo esse estágio do
} 
Essas duas características são intimamente relacionadas, pois só com a possibilidade de um progresso no padrão de vida das classes assalariadas (sem redução da taxa de mais-valia) é possível um aumento da produção sem o perigo de crises de superprodução. Por outro lado, o aumento da mais-valia relativa liga-se ao aumento da produtividade do trabalho; isso significa que o capitalismo é obrigado a promover um novo e espetacular florescimento técnico, o que explica o grande prestígio desfrutado pela racionalidade tecnológica entre determinados setores intelectuais. Nessas condições, o novo capitalismo apresenta-se como "científico", como capaz de resolver as "irracionalidades" que hoje reconhece inerentes a sua época anterior. (COUTINHO, 2010, p. 68).

Nesse período a organização do trabalho industrial acontece pelo taylorismofordismo, estabelecendo dessa maneira um padrão industrial dominante, Antunes (2009, p. 38-39) descreve a organização industrial dessa segunda fase do imperialismo,

De maneira sintética, podemos indicar que o binômio taylorismo/fordismo, expressão dominante do sistema produtivo e de seu respectivo processo de trabalho, que vigorou na grande indústria, ao longo praticamente de todo o século $\mathrm{XX}$, sobretudo a partir da segunda década, baseava-se na produção em massa de mercadorias, que se estruturava a partir de uma produção mais homogeneizada e enormemente verticalizada. Na indústria automobilística taylorista e fordista, grande parte da produção necessária para a fabricação de veículos era realizada internamente, recorrendo-se apenas de maneira secundária ao fornecimento externo, ao setor de autopeças. Era necessário trabalhadores, combatendo o "desperdício" na produção, reduzindo o tempo e aumentando o ritmo de trabalho, visando a intensificação das formas de exploração. Esse padrão produtivo estruturou-se com base no trabalho parcelar e fragmentado, na decomposição das tarefas, que reduzia a ação operária a um conjunto repetitivo de atividades cuja somatória resultava no trabalho coletivo produtor dos veículos. Paralelamente à perda de destreza do labor operário anterior, esse processo de desantropomorfização do trabalho e sua conversão em apêndice da máquina ferramenta dotavam o capital de maior intensidade na extração do sobretrabalho. À mais-valia extraída extensivamente, pelo prolongamento da jornada de trabalho e do acréscimo da sua dimensão absoluta. Intensificava-se de modo prevalente a sua extração intensiva, dada pela dimensão relativa da mais-valia. A subsunção real do trabalho ao capital, própria da fase de maquinaria estava consolidada. Uma linha rígida de produção articulava os diferentes trabalhos, tecendo vínculos entre as ações individuais das quais a esteira fazia as interligações, dando o ritmo e o tempo necessários para a realização das tarefas. Esse processo produtivo caracterizou-se, portanto, pela mescla da produção em série fordista com o cronômetro taylorista, além da vigência de uma separação nítida entre elaboração e execução. Para o capital, tratava-se de apropriar-se do savoir-faire do trabalho, "suprimindo" a dimensão intelectual do trabalho operário, que era transferida para as esferas da gerência científica. A atividade de trabalho reduzia-se a uma ação mecânica e repetitiva. (Grifos do autor).

Esse processo de trabalho correspondeu a um sistema de 'compromisso' e regulação, em que se limitava aos países capitalistas avançados e [...] ofereceu a ilusão de que o sistema de metabolismo social do capital pudesse ser efetiva, duradoura e definitivamente controlado 
[...] (ANTUNES, 2009, p. 40), tal processo foi mediado pelo Estado e regulado pelo capital. Com essa organização industrial a exportação de capitais aumentou entre os próprios países imperialistas, reforçando a hegemonia desses países causando então uma extensão universal, tanto da organização industrial quanto ao estilo de vida norte-americano. Com essa expansão, promovida a partir da década de cinquenta torna-se cada vez mais evidente o papel da indústria cultural. Outras características que também são marcantes dessa época: o crédito ao consumidor; a disponibilidade de determinada quantidade de dinheiro e o crescimento do setor terciário.

No que se refere ao crédito ao consumidor ${ }^{66}$, a partir do final dos anos quarenta essa prática se torna comum, fortalecendo o sub consumo das massas e ampliando o sistema de vendas de crédito ao consumidor, portanto, aquecendo significativamente o mercado. Quanto a disponibilidade de determinada quantidade de dinheiro, tal ação possui uma relação direta com a inflação, para que ocorra a circulação mercantil é fundamental que se disponha certa quantidade de dinheiro, para que essa quantidade seja disponibilizada, dois são os fatores influentes: [...] 1) da soma dos preços das mercadorias em circulação e 2) da velocidade de circulação do dinheiro - quanto maior essa velocidade, menor será a quantidade necessária e vice-versa.(NETTO e BRAZ, 2011, p. 209) ${ }^{67}$. O enorme crescimento do setor terciário ${ }^{68}$

\footnotetext{
${ }^{66}$ Segundo Mandel (1982, p. 281) "A grande expansão do crédito ao consumidor na fase do capitalismo tardio proporciona evidências semelhantes das dificuldades crescentes na realização da mais-valia. $O$ enorme endividamento provado nos Estados Unidos não constitui apenas a base econômica da expansão maciça, desde a Segunda Guerra Mundial, do setor de construção civil; é também a base principal da inflação permanente. O fenômeno dessa dívida prova que, apesar da acelerada inovação tecnológica, dos investimentos maiores e do armamento permanente, o capitalismo tardio não é mais capaz do que o capitalismo juvenil ou o capitalismo monopolista clássico de resolver uma das contradições fundamentais do modo de produção capitalista - a contradição entre a tendência ao desenvolvimento ilimitado das forças produtivas e a tendência a limitação da demanda e do consumo dos "consumidores finais" (cada vez mais constituídos por trabalhadores assalariados). Essa contradição corresponde, é claro, às leis de valorização do próprio capital.

67 "Suponha-se que num ano vendam-se mercadorias num total equivalente a $R \$ 1.000 .000,00$ e que cada real percorra, em média, 50 vezes o ciclo completo da circulação (que consiste em passar do comprador ao vendedor e vice-versa); a massa de dinheiro necessária será a soma dos preços de todas as mercadorias dividida pela velocidade da circulação do dinheiro [...] $\mathbf{2 0 . 0 0 0 , 0 0 ~ [ . . . ] . ~ Q u a n d o ~ a s ~ c e ́ d u l a s ~ e ~ m o e d a s ~ s e m ~ v a l o r ~ i n t r i ́ n s e c o ~ q u e ~}$ substituem a forma histórica original do dinheiro (o ouro) têm o seu valor total equivalente à quantidade de ouro necessária à circulação mercantil, seu poder aquisitivo coincide com o dinheiro sob a forma de ouro - diz-se, então, que são lastreadas: podem ser convertidas em ouro. Mas, frequentemente, o Estado (que, como autoridade monetária, dispõe do monopólio da missão de cédulas e moedas e da guarda, no seu Tesouro ou Banco Central, da quantidade de ouro que serve de lastro à sua moeda), para fazer frente a gastos que não pode cobrir com que arrecada, emite mais cédulas e moedas do que corresponde à sua reserva de ouro. Por exemplo: o Estado emite os R \$20.000,00 mencionados na ilustração acima, dispondo do equivalente em ouro; mas, vendo-se em face de uma situação extraordinária ou da necessidade de saldar despesas, emite outro $\mathrm{R} \$ 20.000,00$, sem que tenha sido alterado a quantidade de lastro ouro e de mercadorias de circulação; então, para adquirir mercadorias que, sem a emissão suplementar, custariam $\mathrm{R} \$ 1,00$, agora serão necessários $\mathrm{R} \$ 2,00$ - é que a moeda foi depreciada, seu poder aquisitivo foi reduzido. É nisso que basicamente consiste a inflação - que não deveria apenas da emissão extraordinária do Estado, mas também da emissão de títulos de crédito por estabelecimentos bancários. Esse fenômeno, que pontualmente ocorreu no século XIX, ganha incidência frequente no estágio imperialista e, nos (anos dourados), adquire um peso tal que alguns economistas, como Mandel, chegam ao ponto de se referir a uma inflação permanente." (NETTO e BRAZ, 2011, p. 209-210).
} 
(setor de serviços) prosseguirá até a ultima fase do imperialismo (o capitalismo contemporâneo $^{69}$ ), nesse setor fica nitidamente explicito o trabalho improdutivo, estão incluídos nesse setor atividades comerciais, educacionais, médicas, financeiras, securitárias, dentre outras. O desenvolvimento desse setor é uma característica típica do modo de produção capitalista sendo "[...] a tendência a mercantilizar todas as atividades humanas, submetendoas à lógica do capital - com efeito mediante "serviços", tomam caráter de mercadoria o trato da educação, da saúde, da cultura, do lazer e os cuidados pessoais (a enfermos, a idosos etc.)." (NETTO e BRAZ, 2011, p. 212).

“O capitalismo do "bem-estar" manipulado, baseado no consumo insensato e antihumano, traz consigo uma falsa sensação de "segurança"," (COUTINHO, 2010, p. 72). O imperialismo, diferentemente do capitalismo concorrencial, necessita de um Estado vá além da produção e acumulação capitalista, necessita de um Estado que garanta as condições gerais na condição de interventor. Sendo assim esse estágio do capitalismo refuncionalizou o Estado, de maneira que:

[...] sua intervenção na economia, direcionada para assegurar os superlucros dos monopólios, visa preservar as condições externas da produção e da acumulação capitalistas, mas implica ainda uma intervenção direta e contínua na dinâmica econômica desde o seu próprio interior, através de funções econômicas diretas e indiretas. (NETTO e BRAZ, 2011, p. 213, Grifos dos autores).

O Estado além de estar inserido em setores aparentemente não rentáveis assumiu também o controle de empresas que estavam em dificuldades, dessa maneira assegurando lhes as taxas de lucro e os subsídios para os monopólios, portanto, além das suas funções indiretas "o Estado sinaliza a direção do desenvolvimento" dando os indicativos das áreas de investimento com retorno posterior. Segundo Netto e Braz (2011) a principal diferença do

\footnotetext{
${ }^{68}$ Mandel (1982, p. 280) afirma que "[...] No capitalismo do século XX, o setor de serviços na esfera da circulação consiste basicamente na troca entre o possuidor de determinada parcela do capital social agregado, que e gasto de maneira improdutiva, e o possuidor de rendimentos (tanto capitalistas quanto assalariados). Essa troca não participa diretamente da determinação da massa total da mais-valia, mas mesmo assim exerce sobre ela influência indireta importante, pois ajuda a aumentar a massa de mais-valia reduzindo o tempo de giro do capital circulante. $\mathrm{O}$ efeito disso sobre a cumulação de capital é a liberação de parte do capital ocioso para participar da distribuição da mais-valia social agregada. Mas, em última instância, essa participação só pode ocorrer por duas vias: ou se dá às expensas daquela parcela de mais-valia distribuída entre os possuidores de capital produtivo (reduzindo assim a taxa média de lucro, ao aumentar o capital total do qual será deduzida a mais-valia total), ou às expensas dos salários - em outras palavras, aumentando a taxa de mais-valia (entre outras formas, por meio de uma contração relativa dos salários reais, decorrente dos aumentos de preço dos bens de consumo)."

${ }^{69}$ Segundo Netto e Braz (2011, p. 235, Grifos dos autores) "“...] o capitalismo contemporâneo particulariza-se pelo fato de, nele, o capital estar destruindo as regulamentações que lhe foram impostas como resultado das lutas do movimento operário e das camadas trabalhadoras".
} 
Estado nos anos dourados e do Estado no capitalismo concorrencial está na exploração e super exploração da força de trabalho.

[...] o que ocorre é que a intervenção estatal desonera o capital de boa parte dos ônus da preservação da força de trabalho, financiados agora pelos tributos recolhidos da massa da população ${ }^{41}$ - financiamento que assegura uma série de serviços públicos (educação, transporte, saúde, habitação etc.). Todas essas funções estatais estão a serviço dos monopólios; porém, elas conferem ao Estado comandado pelo monopólio um alto grau de legitimação. E isso porque, num marco democrático, para servir ao monopólio, o Estado deve incorporar outros interesses sociais; ele não pode ser, simplesmente, um instrumento de coerção - deve desenvolver mecanismos de coesão social. (NETTO e BRAZ, 2011, p. 214-215, Grifos dos autores).

Sendo assim a cidadania moderna passa a ser constituída pelo empenho do Estado em reconhecer os direitos sociais, porém, sempre a serviço dos monopólios, portanto,

\begin{abstract}
Esse processo significou, para segmentos importantes do proletariado europeu "um acréscimo da dependência tanto prática quanto ideológica, em relação ao Estado, sob a forma do famoso 'Estado-providência'. Dentro da moldura do fordismo, com efeito, esse Estado representa para o proletariado, a garantia de 'seguridade social', com sua qualidade de gestor geral da relação salarial: é o Estado que fixa o estatuto mínimo dos assalariados (...); é ele que impulsiona a conclusão e garante o respeito das convenções coletivas; é ele que gera direta ou indiretamente o "salário indireto"" (idem: 59). Tudo isso fez com que se desenvolvesse um fetichismo de Estado, bem como de seus ideais democráticos (inclusive no que eles têm de ilusório), aos quais o 'Estado-providência' deu conteúdo concreto (ao garantir de algum modo o direito ao trabalho, à moradia, à saúde, à educação e à formação profissional, ao lazer etc." (idem: 59-60). O ciclo de expansão e vigência do Welfare State, entretanto, deu sinais de crise. Além das várias manifestações de esgotamento da sua fase de "regulação" keynesiana, às quais nos referimos anteriormente, houve a ocorrência de outro elemento decisivo para a crise do fordismo: o ressurgimento de ações ofensivas do mundo do trabalho e o consequente transbordamento da luta de classes. (ANTUNES, 2009, p. 42).
\end{abstract}

Esse reconhecimento dos trabalhadores foi consequência da pressão que esses fizeram em prol da consolidação de políticas sociais e de sua ampliação, dessa forma várias instituições passaram a compor as várias formas de Bem-Estar Social. Nesse período de trinta anos consolidou-se a mundialização do capital, o capitalismo se tornou predominantemente financeiro e rentista, de modo que o modo político e institucional voltou-se diretamente para os EUA, prolongando assim o estágio do imperialismo.

A estabilidade e dinamismo econômico dos anos dourados do capitalismo monopolista estavam diretamente associados aos direitos sociais, isso no que se refere aos países imperialistas, e a sociedade estava diretamente ligada às políticas democráticas, asseguradas pelas ações sindicais e pelos partidos políticos. Porém, esse capitalismo 
democrático $^{70}$ foi breve, na passagem dos anos sessenta para os anos setenta ele entrou em crise, revertendo algumas das conquistas alcançadas pelos trabalhadores e instaurando o capitalismo contemporâneo. (NETTO e BRAZ, 2011).

Após essa onda longa expansiva, segundo Mandel (1982, p. 85) “[...] Numa fase de expansão, os períodos cíclicos de prosperidade serão mais longos e mais intensos, e mais curtas e mais superficiais as crises cíclicas de superprodução [...]”, as taxas de lucro começaram a declinar, isso entre $1968^{71}$ e 1973, "[...] ela cai, na Alemanha Ocidental, de 16,3\% para 14,2\%, na Grã-Bretanha de 11,9 para 11,2\%, na Itália, de 14,2 para 12,1\%, nos Estados Unidos, de 18,2 para 17,1\%, e, no Japão, de 26,2 para 20,3\% [...]" (NETTO e BRAZ, 2011, p. 223), o crescimento econômico também foi reduzido, dessa maneira nenhum país conseguiu manter os padrões anteriores.

Além das quedas das taxas e do crescimento econômico, fatores sociopolíticos passaram a expressar significativa importância; "[...] ao longo dos anos sessenta e na abertura dos setenta, o peso do movimento sindical aumentou significativamente nos países centrais, demandando não somente melhorias sociais [...]” (NETTO e BRAZ, 2011, p. 223), mais contestando a forma de produção taylorista-fordista. Além dessas questões, novos movimentos também começam a ganhar força, além de reivindicarem direitos civis, esses se caracterizavam com componentes anticapitalistas, por exemplo, nos anos sessenta a revolta estudantil, posteriormente a mobilização dos negros e também o movimento feminista. (Ibidem).

\footnotetext{
70 "Aparentemente, o taylorismo-fordismo e o keynesianismo, feitos uma para o outro, consolidariam o "capitalismo democrático": a produção em larga escala encontraria um mercado em expansão infinita e a intervenção reguladora do Estado haveria de controlar as crises. Anunciava-se um capitalismo sem contradições, apenas conflitivo - mas no quadro de conflitos que seriam resolvidos à base do consenso, capaz de ser construído mediante os mecanismos da democracia representativa. Essa idealização da dinâmica capitalista procurava justificar-se a partir do acúmulo que vinha do período posterior à derrota do fascismo, da reconstrução que se seguiu à Segunda Guerra Mundial, quando se traçavam novas linhas de convivência política e econômica para o mundo que surgia das ruínas da maior tragédia do século XX e que envolviam novas instituições - na política, a Organização das Nações Unidas/ONU; no plano econômico, com os acordos de Bretton Woods, o Banco Mundial/BM e o Fundo Monetário Internacional/FMI." (NETTO e BRAZ, 2011, p. 222-223).

${ }^{71}$ Segundo Netto (2010, p. 259-260) "[...] é tentador estabelecer paralelos e similitudes entre 1848 e $196899:$ movimentos de impacto mundial, dirigidos objetivamente contra a ordem capitalista, derrotados mas que fixaram marcas profundas nesta mesma ordem e a que se sucederam substantivas mudanças econômico-políticas e societárias que redesenharam a sociedade burguesa. [...] No processo de 1968 e suas imediatas derivações, a ofensiva do capital não encontra pela frente uma classe revolucionária ascendente, mas um proletariado que, maduro, paga o ônus de direções sindicais burocratizadas e de um movimento político às vésperas de uma grande crise - no campo socialista, o vestíbulo da rendição às concepções burguesas; no campo comunista, o peso e as consequências da hipoteca estalinista. Sobretudo, incidem no processo as alterações ocorrentes na estrutura social (as diferenciações inter e intraclassistas, a ponderação das novas camadas médias urbanas e seus nascentes movimentos específicos), diretamente condicionados por um aprofundamento da divisão social do trabalho, que vai afetar em especial os segmentos intelectuais."
} 
A ilusão dos “anos dourados” é enterrada em 1974-1975: num processo inédito no pós-guerra, registra-se então uma recessão generalizada, que envolve simultaneamente todas as grandes potências imperialistas e a que se seguiu outra, em 1980-1982, na qual se constatou que "as taxas de lucro voltam a descer ainda mais" e o "recuo do crescimento é ainda mais nítido que em 1974-1975" (Husson, 1999:32). A onda longa expansiva é substituída por uma onda longa recessiva: a partir daí e até os dias atuais, inverte-se o diagrama na dinâmica capitalista: agora, as crises voltam a ser dominantes tornando-se episódicas as retomadas. (Ibidem, 2011, p. 224, Grifos dos autores).

Em função dessa alteração, o capital monopolista se organizou de forma que a restauração do capital fosse pensada e estruturada, portanto, essa resposta se deu a partir de um tripé: a reestruturação produtiva, a financeirização e a ideologia neoliberal ${ }^{72}$, adiante apresentaremos e situaremos esse tripé na história.

\title{
2.1.1 - A reestruturação produtiva
}

\begin{abstract}
A recessão generalizada de 1974-1975 acende o sinal vermelho para o capital monopolista que, a partir de então, implementa uma estratégia política global para reverter a conjuntura que lhe é francamente negativa. O primeiro ataque é o movimento sindical, um dos suportes do sistema de regulação social encarnado nos vários tipos de Welfare State - com o capital atribuindo às conquistas do movimento sindical a responsabilidade pelos gastos públicos com as garantias sociais e a queda das taxas de lucro às suas demandas salariais. Nos finais dos anos setenta, esse ataque se dá por meio de medidas legais restritivas, que reduzem o poder de intervenção do movimento sindical; nos anos oitenta, o assalto do patronato toma formas claramente repressivas - de que são exemplos as ações dos governos Thatcher (Inglaterra) e Reagan (Estados Unidos). (NETTO e BRAZ, 2011, p. 225, Grifos dos autores).
\end{abstract}

Com as alterações na produção, o formato da acumulação taylorista-fordista, acumulação rígida, é alterada para a acumulação flexível. Harvey apud Netto e Braz (2011, p. 225) explica essa forma de acumulação, característica da terceira fase do estágio do imperialismo.

A acumulação flexível [...] se apoia na flexibilidade dos processos de trabalho, dos mercados de trabalho, dos produtos e padrões de consumo. Caracteriza-se pelo surgimento de setores de produção inteiramente novos, novas maneiras de

\footnotetext{
${ }^{72} \mathrm{O}$ neoliberalismo nasceu logo depois da II Guerra Mundial, na região da Europa e da América do Norte onde imperava o capitalismo. Foi uma reação teórica e política veemente contra o Estado intervencionista e de bemestar. Seu texto de origem é O Caminho da Servidão, de Friedrich Hayek, escrito já em 1944. Trata-se de um ataque apaixonado contra qualquer limitação dos mecanismos de mercado por parte do Estado, denunciadas como uma ameaça letal à liberdade, não somente econômica, mas também política. $\mathrm{O}$ alvo imediato de Hayek, naquele momento, era o Partido Trabalhista inglês, às vésperas da eleição geral de 1945 na Inglaterra, que este partido efetivamente venceria. A mensagem de Hayek é drástica: "Apesar de suas boas intenções, a socialdemocracia moderada inglesa conduz ao mesmo desastre que o nazismo alemão - uma servidão moderna". (ANDERSON, 1995, p. 9).
} 
fornecimento de fornecimento de serviços financeiros, novos mercados e, sobretudo, taxas altamente intensificadas de inovação comercial, tecnológica e organizacional.

A nova base técnica passa a ser caracterizada pela microeletrônica e a produção passa a atender mercados específicos, a esse período de transição opera-se a reestruturação produtiva. "[...] Essencial à reestruturação produtiva é uma intensiva incorporação à produção de tecnologias resultantes de avanços técnicos-científicos [...]” (NETTO e BRAZ, 2011, p. 226), essa migração dos suportes eletromecânicos para os eletroeletrônicos afetou diretamente o trabalhador que estava diretamente relacionado a linha de produção. Segundo Netto e Braz (2011) três são as consequências dessa mudança: $1^{\circ}$ - com tamanha mudança, cada vez mais os processos de produção se complexifica, implicando uma extensão das fronteiras do trabalhador coletivo. $2^{\circ}$ - as exigências referentes à força de trabalho requer qualificação e multiplicidade por parte do trabalhador, portanto, passa a exigir que o trabalhador se qualifique e seja polivalente;

[...] Cabe ressaltar, contudo, que, paralelamente àquelas exigências, ocorre um movimento inverso: muitas atividades laborativas são desqualificadas, de forma a empregar uma força de trabalho que pode ser substituída a qualquer momento. Assim, no conjunto dos trabalhadores, encontra-se uma parte extremamente qualificada, que em geral consegue um mínimo de segurança no emprego, e uma grande parcela de trabalhadores precarizados. (Ibidem, p. 227).

$3^{\circ}$ - a gestão da força de trabalho passa a "valorizar" a comunicação e o envolvimento dos trabalhadores, minimizando as hierarquias e disseminando a ideia de que a empresa é uma extensão da sua casa, portanto, estimulando ao "sindicalismo de empresa". "[...] O capital empenha-se em quebrar a consciência de classe dos trabalhadores [...]". (Ibidem, p. 227). Dessa forma, conforme citado anteriormente, a acumulação rígida vai cedendo lugar a acumulação flexível e a uma nova forma de produção o Toyotismo.

Como o toyotismo é baseado em tecnologias capital-intensivas e poupadoras de mão-de-obra, os efeitos sobre a força de trabalho têm sido devastadores, caracterizando um processo de heterogeneização, fragmentação e complexificação da classe trabalhadora (Antunes, 1995; Mattoso, 1996). Observam-se os fenômenos do aprofundamento do desemprego estrutural, da rápida destruição e reconstrução de habilidades, da perda salarial e do retrocesso da luta sindical. (BEHRING, 2008, pp. 35-36).

Portanto, percebe-se que as transformações se direcionam somente para reverter à queda da taxa de lucro e as renovações que aconteceram somente criaram mais condições de 
exploração do trabalhador, precarizando os empregos ${ }^{73}$. Segundo Antunes e Alves (2004) a classe-que-vive-do-trabalho vem vivenciando um processo de enormes mudanças, em que as tendências que compõe esse cenário são: a redução do proletariado industrial em função da reestruturação produtiva, em contrapartida em escala mundial há um aumento do proletariado fabril e dos serviços, serviços esses subcontratados, terceirizados. Houve também um aumento significativo do trabalho feminino, mais de $40 \%$ nos países avançados, este aumento correspondeu a precarização e desregulamentação, se tornando nítidas as diferenças salariais. Outra questão perceptível é a expansão dos salários médios no setor de serviços, portanto,

[...] inicialmente se deu uma forte absorção, pelo setor de serviços, daqueles (as) que se desempregavam do mundo industrial, é necessário acrescentar que as mutações organizacionais, tecnológicas e de gestão também afetaram fortemente o mundo do trabalho nos serviços, que cada vez mais se submetem à racionalidade do capital e à lógica dos mercados. Como exemplos, poderíamos lembrar a enorme redução do contingente de trabalhadores bancários no Brasil dos anos de 1990, em função da reestruturação do setor, ou ainda daqueles serviços públicos que foram privatizados e que geraram enorme desemprego. Com a inter-relação crescente entre mundo produtivo e setor de serviços, vale enfatizar que, em conseqüência dessas mutações, várias atividades no setor de serviços anteriormente consideradas improdutivas tornaram-se diretamente produtivas, subordinadas à lógica exclusiva da racionalidade econômica e da valorização do capital. Uma conseqüência positiva dessa tendência foi o significativo aumento dos níveis de sindicalização dos assalariados médios, ampliando o universo dos trabalhadores (as) assalariados (as), na nova e ampliada configuração da classe trabalhadora. (ANTUNES e ALVES, 204, p. 338-339).

Outra característica que se torna vigente no mundo do trabalho diz respeito à exclusão dos jovens e idosos; quanto aos jovens, estes atingem a idade de ingresso no mercado de trabalho, e por alegação da falta de experiência se tornam números na fila dos desempregados. Quanto aos idosos, a partir dos quarenta anos o mundo do trabalho já se torna relutante em relação ao ingresso no mercado de trabalho, "[...] tem recusado os trabalhadores herdeiros da "cultura fordista", fortemente especializados, que são substituídos pelo trabalhador "polivalente e multifuncional" da era toyotista". (ANTUNES e ALVES, 2004, p. 339).

\footnotetext{
${ }^{73}$ Segundo Netto e Braz (2011, p. 229, Grifos dos autores) "Compreende-se, pois, que o ônus de todas elas (as quedas) recaiam fortemente sobre os trabalhadores - da redução salarial (um exemplo: nos Estados Unidos, entre 1973 e 1992, o preço da hora de trabalho daqueles envolvidos diretamente na produção caiu de UR \$10,37 para UR \$ 8,80) à precarização do emprego. Aqui, aliás, reside um dos aspectos mais expressivos da ofensiva do capital, pela defesa de formas precárias de emprego (sem quaisquer garantias sociais) e do emprego em tempo parcial (também frequentemente sem garantias), que obriga o trabalhador a buscar o seu sustento, simultaneamente, em várias ocupações ${ }^{4}$. Nessa ofensiva do capital, seus porta-vozes vêm afirmando que a "flexibilização" ou a "desregulamentação" das relações de trabalho (isto é, a redução ou mesmo a supressão de garantias ao trabalho) ampliaria as oportunidades de emprego (ou seja, expandiria o mercado de trabalho) argumentação largamente desmentida pelos fatos: também em todos os países onde o trabalho foi "flexibilizado", isso ocorreu juntamente com o crescimento do desemprego.
} 
Outra tendência desse período é o desenvolvimento do Terceiro Setor ${ }^{74}$, este setor passa a 'acolher' os desempregados a partir de atividades sociais, não mercantis, portanto, trata-se de um alternativa compensatória ao desemprego estrutural, porém, não se constitui como duradoura e efetiva em relação ao mercado de trabalho capitalista.

O "Terceiro Setor" acaba, em decorrência de sua próxima gênese e configuração, exercendo um papel funcional ao mercado, uma vez que incorpora parcelas de trabalhadores desempregados pelo capital e abandonados pela desmontagem do Welfare State. Se esse segmento tem a positividade de freqüentemente atuar à margem da lógica mercantil, parece-nos, entretanto, um equívoco entendê-lo como uma real alternativa duradoura e capaz de substituir a sociedade capitalista e de mercado. Essa alternativa tem o papel, em última instância, de funcionalidade ao sistema. (ANTUNES e ALVES, 2004, p. 340).

Dessa forma o Terceiro Setor cumpre com um papel, ainda que limitado, de cobrir as lacunas sociais que foram surgindo com o 'desmonte' do Estado de Bem-Estar-Social e com a perda dos direitos sociais, sendo assim, a partir do momento que são consideradas um momento de efetiva transformação social " [...] convertem- se, em nosso entendimento, em uma nova forma de mistificação, que imagina ser capaz de alterar o sistema de capital em sua lógica, processo este que, sabemos, é muito mais complexo." (ANTUNES e ALVES, 2004, p. 340).

"A noção de uma expansão aparentemente homogênea do setor de serviços, típica do capitalismo tardio, deve ser, portanto, reduzida a seus elementos constitutivos contraditórios." (MANDEL, 1982, p.281), sendo cinco os elementos pontuados pelo autor; $1^{\circ}$ - aumento das funções intermediárias, isso em decorrência da divisão do trabalho e da socialização objetiva do trabalho; $2^{\circ}$ - expansão dos custos de venda e do crédito ao consumidor; $3^{\circ}$ - expansão das necessidades culturais; $4^{\circ}-$ aumento da produção de mercadorias "[...] que não é absolutamente parte do chamado "setor de serviços", mas é resultado da centralização crescente de certas formas de produção que entes eram basicamente privadas" (MANDEL, 1982, p. 282); $5^{\circ}$ - aumento de trabalhadores assalariados de forma improdutiva.

\footnotetext{
74 Segundo Mandel (1982, p. 269) “A separação entre atividades produtivas anteriormente unificadas torna indispensável a ampliação das funções intermediárias. Se a produção artesanal se separa da agricultura, é preciso garantir aos camponeses a mediação dos instrumentos de trabalho e de bens de consumo que antes eles mesmos faziam a mão, e aos artesãos a mediação dos gêneros alimentícios antes produzidos por eles mesmos por meio do comércio. A ampliação dessas funções intermediárias tende a levar a uma independência crescente das mesmas. A separação entre agricultura e produção artesanal leva, em ultima instância, a inserção do comércio independente entre elas. Quanto mais generalizada e produção de mercadorias e quanto mais adiantada a divisão do trabalho, tanto mais essas funções intermediárias precisam ser sistematizadas e racionalizadas, a fim de assegurar produção e venda contínuas. (Grifos do autor).
} 


\begin{abstract}
A expansão do setor de serviços capitalistas que caracteriza o capitalismo tardio resume, portanto, à sua própria maneira, todas as principais contradições do modo de produção capitalista. Reflete a enorme expansão das forças produtivas sóciotécnicas e científicas e o crescimento correspondente das necessidades culturais e civilizadoras dos produtores, exatamente como reflete a forma antagônica em essa expansão realiza sob o capitalismo: pois ela se faz acompanhar de uma supercapitalização crescente (dificuldades de valorização do capital), de dificuldades crescentes de realização, de desperdício crescente de valores materiais e de alienação e deformação crescente dos trabalhadores em sua atividade produtiva e em seu âmbito de consumo. (Ibidem).
\end{abstract}

Quanto ao perfil industrial, percebe-se um movimento de terceirização, ou seja, uma empresa mantém o controle da produção e outras empresas efetivam de fato a produção, dessa maneira alinha-se a uma característica central desse período que é a expansão do trabalho em domicílio, com a desconcentração, flexibilização e precarização do trabalho produtivo, o trabalho doméstico tem se expandido (ANTUNES e ALVES, 2004), característica essa que se espalha pelo mundo, evidenciando a desterritorialização, empresas que detém o monopólio e nada produz, terceirizando o trabalho como exemplo a Nike. (NETTO e BRAZ, 2011).

Com a reconfiguração, tanto do espaço quanto do tempo de produção, novas regiões industriais emergem e muitas desaparecem, além de inserirem-se cada vez mais no mercado mundial, como a indústria automotiva, na qual os carros mundiais praticamente substituem o carro nacional. Esse processo de mundialização produtiva desenvolve uma classe trabalhadora que mescla sua dimensão local, regional, nacional com a esfera internacional. Assim como o capital se transnacionalizou, há um complexo processo de ampliação das fronteiras no interior do mundo do trabalho. Assim como o capital dispõe de seus organismos internacionais, a ação dos trabalhadores deve ser cada vez mais internacionalizada. (ANTUNES e ALVES, 2004, p. 341).

Torna-se evidente que o capitalismo contemporâneo marcou profundamente a vida do trabalhador de tal forma que as garantias atingiram somente a um pequeno núcleo, de maneira geral o panorama foi à alta rotatividade, os salários baixos e as garantias diminuídas, além da perda de força sindicalismo e a redução do número de trabalhadores industriais levando as afirmativas do "fim do trabalho" e a "morte do sujeito revolucionário";

[...] (a redução da demanda de trabalhadores para a produção de bens materiais e o desemprego crescente) são perfeitamente compreensíveis quando se considera a dinâmica essencial da sociedade capitalista e, devidamente analisados, não autorizam a desconsideração da centralidade do trabalho. A redução do contingente de trabalhadores explica-se pelo formidável desenvolvimento das forças produtivas contemporâneas, que exponenciaram a produtividade do trabalho [...] quanto ao extraordinário desemprego dos dias atuais, ele está diretamente ligado aos limites da sociedade burguesa, no interior da qual não há soluções que permitam inscrever todos os homens e mulheres aptos nos circuitos do trabalho - sempre foi própria à sociedade burguesa uma população excedente [...], agora levada a um 
extremo para o qual essa sociedade não tem outra proposta senão a do "terceiro setor" ou a pura e simples assistência social. E ambas as alternativas apenas sinalizam o quanto essa sociedade já não pode responder de forma progressista e humanizadora aos problemas que ela mesma engendra. (NETTO e BRAZ, 2011, p. $60)$.

Portanto,

Longe de representar uma "sociedade pós-industrial", o capitalismo tardio constitui uma industrialização generalizada universal pela primeira vez na história. A mecanização, a padronização, a super-especialização e a fragmentação do trabalho, que no passado determinaram apenas os reino da produção de mercadorias na indústria propriamente dita, penetram agora todos os setores da vida social. (MANDEL, 1982, p. 271).

Com essa ofensiva do capital, as características mais marcantes do capitalismo contemporâneo, se tornam a naturalização do desemprego e a exponenciação da questão social. Os ideólogos tratam o desemprego pela ideia de convivência, como se fosse normal um exército industrial de reserva. Se tratando da exponenciação da questão social também se torna naturalizada, porém a criminalização do pobre causa repressão e tolerância zero. Diante dessas influências da reestruturação produtiva mencionaremos adiante a financeirização e as características que compõe essa terceira fase do capitalismo, o imperialismo.

\title{
2.1.2 - A financeirização ${ }^{75}$
}

Com a expansão e os novos domínios do capital os organismos internacionais passaram a influenciar diretamente na concentração e a centralização do poder,

\begin{abstract}
É nesses domínios que o comando do capital se afirma impetuosamente, sempre com a direção monopolista assegurando-lhe não só ganhos extraordinários (especialmente os derivados das rendas tecnológicas que, segundo Mandel, advém da redução de custos pela introdução de novas tecnologias), mas sobretudo o controle estratégico dos novos recursos necessários à produção de ponta. Esse controle estratégico é garantido, em primeiro lugar, pelo assombroso grau de concentração e centralização a que chegou a economia mundial ${ }^{11}$ - sem prejuízo, simultaneamente, da continuidade da concorrência intercapitalista e do aparecimento de novas formas de associação. Em segundo lugar, e em consequência dessa concentração e centralização, os grupos monopolistas (ancorados em organizações que se tornaram corporações megaempresariais) desenvolveram interações novas [...], nas quais a concorrência e a parceria encontram mecanismos de articulação que lhes asseguram um poder decisório especial. (NETTO e BRAZ, 2011, p. 233-234, Grifos dos autores).
\end{abstract}

\footnotetext{
75 Segundo Behring (2008, pp.40-41) "As metamorfoses do mundo do trabalho são acompanhadas pelo que alguns denominam de globalização, mas que, incorporando a contribuição de Chesnais (1996 e 1997), pode ser apontado como processo de mundialização da economia, de constituição de um regime de acumulação mundial predominantemente financeiro, ou melhor, "uma nova configuração do capitalismo mundial e dos mecanismos que comandam seu desempenho e sua regulação" (1996: 13). ${ }^{11, "}$
} 
As interações comerciais intensificaram entre os países centrais, de forma que a liderança constituiu a chamada tríade (Estados Unidos, União Européia e Japão), tais países realizam entre si grandes transações comerciais, [...] fundamentalmente operadas pelos grandes monopólios e processadas entre suas matrizes e filiais/subsidiárias (trata-se do comércio chamado intracorporativo). (NETTO e BRAZ, 2011, p. 239). Dessa forma o comércio e a capacidade de investimento vinculam-se diretamente as transnacionais, portanto,

[...] Chesnais detém-se em uma caracterização das mudanças em suas estruturas e movimentos estratégicos. Ele incorpora o estudo de Michalet (1985, apud Chesnais, 1986) que estabelece três tipos de estratégias empresariais em nível internacional e anuncia um quarto. São elas: estratégias de aprovisionamento, características de transnacionais do setor primário, especializadas em integração vertical a partir de recursos situados no Terceiro Mundo; estratégias de mercado, com o estabelecimento de filiais intermediárias (também chamado de enfoque multidoméstico); estratégias de produção racionalizada, diga-se, integrada internacionalmente, com o estabelecimento de filiais montadoras; e por fim, estratégias tecno-financeiras das empresas (1996: 75). (BEHRING, 2008, p. 43).

Tais estratégias passaram a influenciar nas relações econômicas internacionais, caracterizando o capitalismo contemporâneo com a estruturação de blocos supranacionais que passam a organizar normas específicas para as transações, e consequentemente promovendo a interação entre os mercados, tudo isso sob comando monopolista. Nesse contexto o processo de financeirização do capital passa a ter suporte do sistema bancário, resultando da

[...] superacumulação e, ainda, da queda das taxas de lucro dos investimentos industriais registrada entre os anos setenta e meados dos oitenta. Na medida em que "o capitalismo é um sistema econômico que prefere não produzir em vez de produzir sem lucro" (Husson, 1999: 89), compreende-se que um montante fabuloso de capital disponibilizou-se então sob a forma de capital-dinheiro [...]. Parte desse capital foi investido na produção, e especialmente, no setor de serviços em outros países pelas corporações imperialistas (representando o chamado investimento externo direto/IED), aliás um dos dínamos da mundialização. Parte substitutiva, porém, permaneceu no circulo da circulação buscando valorizar-se nesta esfera. [...] apenas na produção se cria valor - na circulação não há geração de valor; mas também vimos que a realização dos valores se expressa na circulação [...]. (NETTO e BRAZ, 2011, p. 241).

À medida que o capitalismo foi se desenvolvendo muitos capitalistas passaram a viver desse capital, de forma que não se responsabilizaram em investir na produção. $\mathrm{O}$ capitalismo contemporâneo reflete esse crescimento, “[...] dessa massa de capital dinheiro 
que não é investida produtivamente [...]" (NETTO e BRAZ, 2011, p. 241), mais continua a ganhar, fortalecendo o crescimento do capital fictício $^{76}$. Sendo assim,

\begin{abstract}
A financeirização do capitalismo contemporâneo deve-se a que as transações financeiras (isto é: as operações situadas na esfera da circulação) tornaram-se sob todos os sentidos hipertrofiados e desproporcionais em relação à produção real de valores - tornaram-se dominantemente especulativos. Os rentistas e os possuidores de capital fictício (ações, cotas de fundos de investimentos, títulos de dívidas públicas) extraem ganhos sobre valores frequentemente imaginários - e só descobrem isso quando, nas crises do "mercado financeiro", papéis que, à noite, "valiam" $X$, na bela manhã seguinte passam a "valer" $X$ ou, literalmente, a não "valer" nada [...]. (NETTO e BRAZ, 2011, p. 242).
\end{abstract}

\title{
2.1.3 - A ideologia neoliberal ${ }^{77}$
}

\section{“[...] A pretensão do grande capital é clara: destruir qualquer trava extra -} econômica aos seus movimentos. [...]”" (NETTO e BRAZ, 2011, p. 236), impedindo qualquer forma de controle, regulamentação ou limite contra a sua expansão, portanto, sua estratégia mundial é romper com qualquer barreira sociopolítica. A partir desses ideais, Hayek ${ }^{78}$ idealizou teses de extremo conservadorismo e as defendeu, difundindo-as desde os anos quarenta, mais somente na década de setenta ${ }^{79}$ que esse conjunto ideológico (neoliberalismo) toma proporções imensuráveis, os seus objetivos consistiam em:

\footnotetext{
${ }^{76}$ Segundo Netto e Braz (2011, p. 242, Grifos dos autores) "Entende-se por capital fictício "as ações, as obrigações e os outros títulos de valor que não possuem valor em si mesmos. Representam apenas um título de propriedade, que dá direito a um rendimento [...]" (Koslov, dir., 1, 1981: 217). Assim como o capitalismo não pode funcionar sem uma determinada massa de capital conservada enquanto capital dinheiro, também não pode funcionar sem capitais fictícios - mas, do mesmo modo que contemporaneamente aquela massa cresceu de forma espetacular, igualmente cresceu, de modo assombroso, o montante do capital fictício. Esse crescimento tem sido de caráter nitidamente especulativo, ou seja: não guarda a menor correspondência com a massa de valores reais."

77 Alguns autores afirmam que a reestruturação produtiva é um processo de reação burguesa e a Ideologia Neoliberal protagonizou, "[...] O que se pode denominar ideologia neoliberal compreende uma concepção de homem (considerando atomisticamente como possessivo, competitivo e calculista), uma concepção de sociedade (tomada como agregado fortuito, meio de o indivíduo realizar seus propósitos privados) fundada na idéia da natural e necessária desigualdade entre os homens e uma noção rasteira da liberdade (vista como função da liberdade de mercado)." (NETTO E BRAZ, 2011, p. 236).

${ }_{78}$ Segundo Netto e Braz (2011, p. 236, Grifos dos autores) "Para legitimar essa estratégia, o grande capital fomentou e patrocinou a divulgação maciça do conjunto ideológico que se difundiu sob designação de neoliberalismo - a disseminação das teses, profundamente conservadoras, originalmente defendidas desde os anos quarenta do século XX pelo economista austríaco F. Hayek (1899-1992), que dividiu em 1974 o Prêmio Nobel de Economia com Gunnar Myrdal”.

${ }^{79}$ A chegada da grande crise do modelo econômico do pós-guerra, em 1973, quando todo o mundo capitalista avançado caiu numa longa e profunda recessão, combinando, pela primeira vez, baixas taxas de crescimento com altas taxas de inflação, mudou tudo. A partir daí as idéias neoliberais passaram a ganhar terreno. As raízes da crise, afirmavam Hayek e seus companheiros, estavam localizadas no poder excessivo e nefasto dos sindicatos e, de maneira mais geral, do movimento operário, que havia corroído as bases de acumulação capitalista com suas pressões reivindicativas sobre os salários e com sua pressão parasitária para que o Estado aumentasse cada vez mais os gastos sociais. (ANDERSON, 1995, p. 10).
} 
[...] combater o keynesianismo e o solidarismo reinantes e preparar as bases de um outro tipo de capitalismo, duro e livre de regras para o futuro. As condições para este trabalho não eram de todo favoráveis, uma vez que o capitalismo avançado estava entrando numa longa fase de auge sem precedentes - sua idade de ouro - , apresentando o crescimento mais rápido da história, durante as décadas de 50 e 60 . Por esta razão, não pareciam muito verossímeis os avisos neoliberais dos perigos que representavam qualquer regulação do mercado por parte do Estado. A polêmica contra a regulação social, no entanto, tem uma repercussão um pouco maior. Hayek e seus companheiros argumentavam que o novo igualitarismo (muito relativo, bem entendido) deste período, promovido pelo Estado de bem-estar, destruía a liberdade dos cidadãos e a vitalidade da concorrência, da qual dependia a prosperidade de todos. Desafiando o consenso oficial da época, eles argumentavam que a desigualdade era um valor positivo - na realidade imprescindível em si -, pois disso precisavam as sociedades ocidentais. Esta mensagem permaneceu na teoria por mais ou menos 20 anos. (ANDERSON, 1995, p. 10).

Com os primeiros sinais da crise, Hayek apontou que a deterioração dos lucros aconteceu pelo poder excessivo cedido aos sindicatos, de maneira geral o movimento operário, que ao pressionarem conquistaram alguns direitos e consequentemente aumentou os gastos sociais do Estado. Para a reversão desse contexto a ideologia neoliberal se legitima a partir de um projeto monopolista que objetivava minimizar, e até mesmo sanar as restrições sociopolíticas que limitavam o movimento, porém, a solução era “[...] manter um Estado forte, sim, em sua capacidade de romper o poder dos sindicatos e no controle do dinheiro, mas parco em todos os gastos sociais e nas intervenções econômicas. [...]" (ANDERSON, 1995, p. 11).

Nesse período os neoliberais advertiram sobre a necessidade de uma reforma ${ }^{80}$, apontando a imediaticidade dos cortes de "gorduras" do Estado ${ }^{81}$, se tornando evidente a movimentação ofensiva do capital contra as dimensões democráticas, para que a estabilidade se reestabelecesse foi fundamental a contenção de gastos, a 'restauração' da taxa de desemprego e a redução dos impostos sobre as rendas mais altas. $\mathrm{O}$ contexto de crise se

\footnotetext{
${ }^{80}$ Segundo Netto e Braz (2011, p. 237, Grifos dos autores) “"...] pela primeira vez na história do capitalismo, a palavra reforma perdeu o seu sentido tradicional de conjunto de mudanças para ampliar direitos; a partir dos anos oitenta do século $X X$, sob o rótulo de reforma(s) o que vem sendo conduzido pelo grande capital é um gigantesco processo de contra-reforma(s), destinado a supressão ou redução de direitos e garantias sociais."

${ }^{81}$ Segundo Behring $(2008$, p. 58) "Em relação ao Estado, portanto, existem fortes repercussões dos processos delineados anteriormente - a reestruturação produtiva e a mundialização - que configuram as linhas gerais de uma verdadeira contra-reforma. Esta adquire maior ou menor profundidade, dependendo das escolhas políticas dos governos em sua relação com as classes sociais em cada espaço nacional, considerando a diretiva de classe que hegemoniza as decisões no âmbito do Estado (Behring, 2002: 32-3). Escolhas que se relacionam e resultam também do tempo histórico em que esta contra-reforma se instaura nas diferentes formações sociais. Trata-se de uma contra-reforma, já que existe uma forte evocação do passado no pensamento neoliberal22, bem como um aspecto realmente regressivo quando da implementação de seu receituário, na medida em que são observadas as condições de vida e de trabalho das maiorias, bem como as condições de participação política. Que linhas gerais são essas? As políticas neoliberais comportam algumas orientações / condições que se combinam, tendo em vista a inserção de um país na dinâmica do capitalismo contemporâneo, marcada pela busca de rentabilidade do capital por meio da reestruturação produtiva e da mundialização: atratividade, adaptação, flexibilidade e competitividade.
} 
'reestabeleceu', a desigualdade foi acentuada e um movimento de direitização tomou o contexto mundial.

\begin{abstract}
A hegemonia deste programa não se realizou do dia para a noite. Levou mais ou menos uma década, os anos 70, quando a maioria dos governos da OCDE Organização Européia para o Comércio e Desenvolvimento - tratava de aplicar remédios keynesianos às crises econômicas. Mas, ao final da década, em 1979, surgiu a oportunidade. Na Inglaterra, foi eleito o governo Thatcher, o primeiro regime de um país de capitalismo avançado publicamente empenhado em pôr em prática o programa neoliberal. Um ano depois, em 1980, Reagan chegou a presidência dos Estados Unidos. Em 1982, Khol derrotou o regime social liberal de Helmut Schimidt, na Alemanha. Em 1983, a Dinamarca, Estado modelo do bemestar escandinavo, caiu sob o controle de uma coalizão clara de direita, o governo de Schluter. Em seguida, quase todos os países do norte da Europa ocidental, com exceção da Suécia e da Áustria, também viraram à direita. A partir daí, a onda de direitização desses anos tinha um fundo político para além da crise econômica do período. (ANDERSON, 1995, p. 11).
\end{abstract}

As práticas dos governos neoliberais se deram de maneiras distintas, sendo o modelo inglês o mais puro. $\mathrm{O}$ neoliberalismo inglês caracterizou pela contração monetária, elevação das taxas de juros, baixaram os impostos sobre os altos investimentos, extinguiram o controle sobre os fluxos financeiros, criaram níveis massivos de desemprego, derrotaram as greves, criaram leis anti-sindicais, sanaram os gastos sociais e iniciaram um programa de privatizações. "[...] Esse pacote de medidas é o mais sistemático e ambicioso de todas as experiências neoliberais em países de capitalismo avançado. [...]” (ANDERSON, 1995, p. 12).

A prioridade neoliberal dos Estados Unidos era a competição militar, o presidente Reagan se lançou em uma corrida bélica contra a União Soviética, em uma tentativa estratégica de derrubar o regime comunista da Rússia, “[...] não respeitou a disciplina orçamentária; ao contrário, lançou-se numa corrida armamentista sem precedentes, envolvendo gastos militares enormes, que criaram um déficit público muito maior do que qualquer outro presidente da história norte-americana. [...]" (ANDERSON, 1995, p.12), isso por que a sua realidade referente ao Estado de bem-estar-social quase não existia. Quanto a política interna Reagan baixou os impostos sobre os altos investimentos, elevou as taxas de juros e derrotou uma única greve no período do seu governo.

$\mathrm{Na}$ Europa houve uma disciplina orçamentária e algumas reformas fiscais, porém, o enfrentamento com os sindicatos e os cortes sociais não deixaram de acontecer. O panorama europeu se distinguiu também n contexto político, ao norte países com governos de direita e 
ao sul governos de esquerda $^{82}$, diferentemente da Austrália e da Nova Zelândia que apresentaram um desmonte feroz contra o Estado de bem-estar-social.

O que demonstravam estas experiências era a hegemonia alcançada pelo neoliberalismo como ideologia. [...] O neoliberalismo havia começado tomando a social-democracia como sua inimiga central, em países de capitalismo avançado, provocando uma hostilidade recíproca por parte da social-democracia. Depois, os governos social-democratas se mostraram os mais resolutos em aplicar políticas neoliberais. Nem todas as social-democracias, bem entendido. Ao final dos anos 80, a Suécia e a Áustria ainda resistiam à onda neoliberal da Europa. (ANDERSON, 1995, p. 14).

Embora alguns países tivessem resistido a essa ideologia, podemos afirmar que houve uma hegemonia neoliberalista, isso nos anos 80. Sendo assim a prioridade imediata neoliberal, que era deter a inflação dos anos setenta, foi conquistada, além dos aumentos das taxas de lucro das indústrias e das taxas de desemprego, e consequentemente a desigualdade, "[...] Então, em todos estes itens, deflação, lucros, empregos e salários, podemos dizer que o programa neoliberal se mostrou realista e obteve êxito. [...]" (ANDERSON, 1995, p. 15).

\begin{abstract}
Cabe perguntar por que a recuperação dos lucros não levou a uma recuperação dos investimentos. Essencialmente, pode-se dizer, porque a desregulamentação financeira, que foi um elemento tão importante do programa neoliberal, criou condições muito mais propícias para a inversão especulativa do que produtiva. Durante os anos 80 aconteceu uma verdadeira explosão dos mercados de câmbio internacionais, cujas transações, puramente monetárias, acabaram por diminuir o comércio mundial de mercadorias reais. $\mathrm{O}$ peso de operações puramente parasitárias teve um incremento vertiginoso nestes anos. (Ibidem, p. 16).
\end{abstract}

Devido o aumento das taxas de desemprego e da população aposentada, o Estado aumentou seus gastos sociais e o bem-estar-social não foi diminuído conforme o esperado, sendo assim em 1991 o capitalismo avançado entra em uma significativa recessão, nesse contexto de crise esperava-se uma reação contra o neoliberalismo, mais o que aconteceu foi

\footnotetext{
${ }^{82}$ Segundo Anderson (1995, pp. 13-14) "Todos se apresentavam como uma alternativa progressista, baseada em movimentos operários ou populares, contrastando com a linha reacionária dos governos de Reagan, Thatcher, Khol e outros do norte da Europa. Não há dúvida, com efeito, de que pelo menos Miterrand e Papandreou, na França e na Grécia, genuinamente se esforçaram para realizar uma política de deflação e redistribuição, de pleno emprego e de proteção social. Foi uma tentativa de criar um equivalente no sul da Europa do que havia sido a social-democracia do pós-guerra no norte do continente em seus anos de ouro. Mas o projeto fracassou, e já em 1982 e 1983 o governo socialista na França se viu forçado pelos mercados financeiros internacionais a mudar seu curso dramaticamente e reorientar-se para fazer uma política muito próxima à ortodoxia neoliberal, com prioridade para a estabilidade monetária, a contenção do orçamento, concessões fiscais aos detentores de capital e abandono do pleno emprego. No final da década, o nível de desemprego na França socialista era mais alto do que na Inglaterra conservadora, como Thatcher se gabava amiúde de assinalar. Na Espanha, o governo de González jamais tratou de realizar uma política keynesiana ou redistributiva. Ao contrário, desde o início o regime do partido no poder se mostrou firmemente monetarista em sua política econômica: grande amigo do capital financeiro, favorável ao princípio de privatização e sereno quando o desemprego na Espanha rapidamente alcançou o recorde europeu de $20 \%$ da população ativa".
} 
uma reação contrária. Na Inglaterra a vitória de Major perpetua o thatcherismo, na Suécia em 1991 a resistência da social-democracia é derrotada pela direita, na França o socialismo perdeu força, na Itália Berlusconi toma frente e é comparado com Reagan, na Alemanha Kohl continuou no poder e na Espanha a direita se manteve.

\begin{abstract}
O colapso do mundo comunista no leste europeu - a queda do "socialismo real" e do muro de Berlim - caracteriza-se como uma vitória expoente do neoliberalismo e não de qualquer tipo de capitalismo, pois essa vitória apresenta-se como um respiro, já que seus limites estruturais começavam a tornar-se evidentes. Os países do póscomunismo foram os responsáveis pelas reformas neoliberais mais profundas e devastadoras. (HÚNGARO, 2012, p. 47).
\end{abstract}

Com a crise dos anos noventa o projeto socialista revolucionário experimenta um delicado momento, a 'pós-modernidade' passou a sugerir o fim revolucionário, desqualificando a obre de Marx. Com esse conturbado contexto a ordem burguesa recupera os ideais sobre o 'fim da história', “[...] os passos em direção a uma ordem social diferente (o comunismo) revelaram-se um equívoco e sua sustentação (a obra marxiana) um sistema de erros; há que corrigir o desvio e retornar à 'sociedade livre fundada no mercado' [...]" (NETTO apud HÚNGARO, 2012, p. 47). Portanto, a hegemonia neoliberal " [...] foi tão grande que possibilitou a efetivação de políticas neoliberais por governo que se autodenominavam de esquerda. [...]" (HÚNGARO, 2012, p. 49).

Além da forte influência, a social-democracia passou a incorporar em suas políticas condições neoliberais, formatações neoliberais passaram a influenciar também os países do socialismo real, países esses que compunham a URSS. Porém, algumas questões estavam fora do alcance dos neoliberalistas como: o aumento da desigualdade social, as crises ecológicas, o aumento do racismo e da xenofobia. (HÚNGARO, 2012). A ofensiva neoliberal se instaura de tal modo que há uma restauração do grande capital, Netto (2010) nos apresenta um panorama geral e as implicações dessas mudanças.

A recessão de 1974/1975, a primeira "generalizada desde a Segunda Guerra Mundial, sendo a única, até então, a golpear simultaneamente todas as grandes potências imperialistas" ${ }^{\text {"88 }}$, ascendeu a luz vermelha para aqueles núcleos que articuladamente, numa ofensiva prático-política para a plena restauração do poder do capital. Conjugando intervenções repressivas (de que logo após a destruição do movimento sindical mineiro inglês por Tatcher se tornaria exemplar) e operações ideológicas de grande fôlego - das quais o marco fulcral seria, na sequência dos

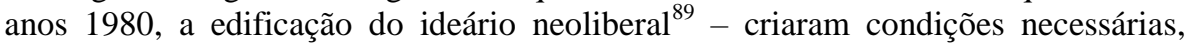
contando com as rápidas absorção e conversão em novas tecnologias das conquistas da revolução científica que estava em curso desde os anos 1960 (agora tomando as cores da revolução informacional), para a sua empreitada, que teve como base material a "reestruturação produtiva" $"$. A crise do movimento sindical, a falência do "socialismo real" e o colapso da maioria dos partidos comunistas, assim como a 
mais completa autodomesticação dos partidos social-democratas - bem expressa, logo a seguir, na "terceira via" - confluíram para o êxito da ofensiva capitalista. Por sobre as ilusões perdidas do rescaldo das explosões de 1968 (absolutamente não exclusivas da França) ${ }^{* 2}$, ergueu-se de fato um mundo em que se viu restaurado o poder do (grande) capital. (Ibidem, p. 257-258).

Dessa maneira o capitalismo contemporâneo passa a reger todo o mundo de forma que as análises que foram feitas em 1970 não serão as mesmas análises do atual contexto, pois, são “[...] novos problemas, novas questões e novas alternativas se põem na sua realidade - é despiciendo, pois, insistir nos desafios teóricos e analíticos que o capitalismo contemporâneo coloca aos seus estudiosos. [...]”. (NETTO, 2010, p. 258). Portanto, não deixa de ser capitalismo, ainda continua a produzir/reproduzir as relações sociais baseado na exploração do homem pelo homem, com limites e contradições próprias da estrutura do sistema.

Que a burguesia obteve êxito na 'reconstrução' da ofensiva do capital, isso é nítido, porém, as resistências não se esvaíram, “[...] De fato, se não se visualiza imediatamente o protagonismo de um sujeito revolucionário tal como se evidenciou dos finais do século 19 aos inícios do terceiro quartel do século 20 [...]” (NETTO, 2010, p. 259, Grifo do autor), mais isso não significa o seu fim.

[...] não há nenhuma razão estrutural e sistêmica para inferir daí o seu desaparecimento; antes, sua debilidade e/ou ausência conjunturais na vanguarda das lutas anticapitalistas são fenômenos compreensíveis como resultante imediata da vitória da ofensiva do capital, cuja reversibilidade é perfeitamente possível e viável com a emersão aberta das novas contradições e polarizações em curso no capitalismo contemporâneo (e com iniciativas político-organizacionais destinadas a pô-lo em causa). Se se experimenta, dado o êxito daquela ofensiva, uma nítida quadra histórica regressiva e contrarrevolucionária, nem por isto há fundamento que permita supô-la perene. (Ibidem).

A partir desse contexto, percebe-se que "[...] a realidade da ordem burguesa contemporânea aparece como derivada do dinamismo interno da razão incondicionada, que tudo pode." (NETTO, 2010, p. 263), sendo assim,

[...] esse idealismo não é inocente: ao creditar à razão moderna a realidade históricosocial contemporânea, o que fica na sombra é a ordem do capital, com a dominação de classe da burguesia*110; se à grande burguesia a crítica aberta a propriedade privada dos meios fundamentais de produção, a referência direta à exploração, o apelo à luta de classes e ao socialismo permanecem intoleráveis, não causam mossa as demandas da inclusão social, de combate às desigualdades, de requisições de cidadania e de solidariedade e de apelo a uma sociedade alternativa. (Ibidem). 
Portanto, a miséria da razão enquanto expressão de um movimento real tem se tornado preocupante e para reversão dessa ofensiva do capital

[...] faz-se necessário que a realidade tenda para a teoria e para isso é fundamental a emergência de um movimento de massas que seja uma ameaça concreta à ordem do capital. Enquanto tal movimento não se torna visível, no debate acadêmico, cabe-nos a "batalha das idéias" que, tendo em vista as circunstâncias concretas em que ela vem sendo travada, exige a retomada da interlocução com Marx. Apesar de insuficiente, Marx é absolutamente necessário para a compreensão das complexas determinações da sociedade contemporânea e tal compreensão, por sua vez - na melhor inspiração moderna - é vital para alimentar uma intervenção revolucionária. (HÚNGARO, 2010, p. ).

\title{
2.2 - Miséria da razão: expressão de um movimento real ${ }^{83}$
}

Segundo Coutinho (2010) a decadência ideológica desemboca em dois vieses, o irracionalismo e a miséria da razão, nesse contexto o irracionalismo se vincula a deturpação ideológica e a miséria da razão se direciona para o pragmatismo ${ }^{84}$, sendo assim podemos afirmar que a miséria da razão,

\begin{abstract}
Assume a racionalidade burocrática (própria da manipulação) e as devastações humanas que ela impõe ao seu objeto como premissas do seu sistema teórico. Afirma que o homem é um puro "dado" passivo de estruturas apriorísticas, que a liberdade é apenas uma "ilusão", que o humanismo (os problemas da construção do homem por si mesmo) são um "falso problema", uma mera "doxologia". Ao proclamar a "morte da ideologia", pretende precisamente decretar como irracionais, como problemas alheios à ciência e à razão, as questões do sentido da vida, da luta por uma nova sociedade, da liberdade humana real. (Ibidem, p. 74).
\end{abstract}

Como expressão real da miséria da razão e confirmação do pragmatismo, no contexto da ciência, temos o produtivismo ${ }^{85}$, este corresponde à produção em larga escala em prol da

\footnotetext{
${ }^{83}$ Segundo Netto (2010, p. 255-256) "“...] a decadência ideológica, subjacente ao novo espirito do tempo, não tem fronteiras nacionais e envolve o conjunto do mundo ocidental; "a verdade é que nos cinco anos que vão de 1974 a 1979, tudo mudou drasticamente na Europa e nos Estados Unidos, impondo-se um conservadorismo cada vez mais beligerante" - constata um analista latino-americano que, tratando a seguir a "década de 1980 como uma era do conservadorismo", conclui: "eis aí o grande triunfo da burguesia imperialista"*80 [...]. Esta apreciação está longe de ser um juízo isolado; vários estudiosos, a partir de perspectivas teóricas distintas, verificam e analisam a maré-montante conservadora e direitizante (quando não francamente de direita, abertamente regressiva) em que submerge a cultura dos últimos 30 anos em praticamente todo o mundo ${ }^{81}$."

${ }^{84} \mathrm{O}$ significado de pragmatismo, pelo dicionário é a seguinte: "pragmatismo $\mathrm{sm}$. Filos. Doutrina segundo a qual as idéias são instrumentos de ação que só valem se produzem efeitos práticos." (FERREIRA, 2001, p. 550, Grifo do autor).

85 “Cabe aqui destacar que a importância da produção de conhecimento não está em questão. De fato, é consenso que "produzir conhecimento é responsabilidade dos pesquisadores e que formar bons pesquisadores requer uma atuação regular em pesquisa". Considerando que a quase totalidade das pesquisas realizadas nos programas de Pós-Graduação é viabilizada com recursos públicos, além da necessidade de disseminar o conhecimento e validar a sua qualidade por meio da apreciação pelos pares, pesquisar e publicar seus resultados faz parte do compromisso social do pesquisador. Assim sendo, não se questiona que um corpo docente qualificado,
} 
manutenção dos credenciamentos na pós-graduação, a questão em voga não é a produção do conhecimento mais sim produzir conhecimento de maneira responsável e sensata, portanto,

\begin{abstract}
O que deve ser legitimamente combatido é a limitação da racionalidade às categorias intelectivas, limitação que caracteriza as orientações ligadas à "miséria da razão". Considerando "incognoscíveis" as configurações ontológicas que são objeto da razão, essa posição limitadora e agnóstica contribui para reforçar o aberto irracionalismo. (COUTINHO, 2010, p. 96).
\end{abstract}

Essa posição limitadora e agnóstica provoca o afastamento da ontologia, ocasionando a deturpação da realidade objetiva cedendo espaço para a racionalidade formalista, o que torna a interpretação da realidade submetida a uma série de leis 'formalistas'. Portanto,

[...] essa "miséria" da razão e da objetividade desempenha, seja ou não essa a
intenção de seus realizadores, uma função reacionária: a de impedir que os homens
rompam com a atual manipulação, com a espontaneidade "inconsciente" da
alienação, redescobrindo o sentido criador e dialético de uma práxis apropriadora e
universal. O positivismo dos estruturalistas converte-se numa involuntária apologia
do capitalismo de manipulação. Diante desse novo fetichismo, devemos realizar o
mesmo movimento que Marx efetuou ante o "fetichismo da mercadoria": devemos
dissolver a aparente "coisidade" dessas estruturas pseudo-onipotentes nas relações
inter-humanas, na práxis social onde têm sua gênese concreta. (COUTINHO, 2010,
p. 99).

Sendo assim, acreditamos que através da batalha das ideias podemos revolucionar o atual, na tentativa de superação do imediatismo dessas circunstâncias, que nos evidenciam indicativos contundentes da manipulação dos elementos do real para a articulação de tendências ideológicas que reafirmam o conformismo em torno da ordem vigente.

Partindo dessa fundamentação teórica, o que tentaremos a seguir é apresentar e fundamentar a Política Nacional de Pós-Graduação, se a realidade é um todo articulado não há, portanto, possibilidade de não estabelecermos relações das determinações objetivas da realidade com o atual contexto da Pós-graduação.

responsável pela formação de professor/pesquisadores, tem o compromisso de transmitir e, também, de produzir conhecimento relevante que seja capaz de transformar problemas em soluções. Mais do que a negação da necessidade de considerar a produção científica na avaliação da Pós-Graduação, a insatisfação parece residir na forma como ela é conduzida, que leva a uma escalada altíssima da produção (a tal "altura do sarrafo"), processo que comumente é denominado de "produtivismo". (RECHIA; SILVA; ALMEIDA, 2015, p. 11). 


\title{
2.2.1 - A política de pós-graduação brasileira: determinações históricas e teóricas ${ }^{86}$
}

Ainda em 1945, quando o 'processo democrático' se reestabeleceu “[...] diferentes forças (empresários internacionais; camadas médias; operariado e as incipientes forças de esquerda) vão lutar não pró ou contra a industrialização, mas pelo controle do processo que a desencadeava”. (SACARDO, 2012, p. 87). Esse processo marcou o início da década de 1960 que ficou conhecida pelo significativo desenvolvimento das indústrias e pela 'era' desenvolvimentista de JK - "50 anos em 5" - esse contexto desenvolvimentista, surgiu da crise do café, com a substituição das importações e com a crise geral do capitalismo, em meio a essas situações conturbadas e com medo da instabilidade financeira, diferentes bandeiras uniram forças para alavancar ainda mais a industrialização.

\begin{abstract}
Enquanto o processo de industrialização avançava, desdobrava-se, por um lado, a partir da perspectiva desenvolvimentista, elaborada e divulgada pelo Instituto Superior de Estudos Brasileiros (ISEB), a ideologia nacionalista desenvolvimentista e, por outro, era formulada pela Escola Superior de Guerra (ESG), a ideologia da interdependência (SAVIANI, 2008b). Essa polarização desencadeou a crise do início da década de 1960, por meio da contradição entre modelo econômico e ideologia política vigente. (Ibidem, p. 87-88).
\end{abstract}

Com a chamada "Revolução" de $1964^{87}$ houveram ajustes na ideologia política para adequação ao modelo econômico em voga, este modelo se configurava como doutrina da segurança nacional, portanto as consequências dessa adequação se deu na substituição da ideologia desenvolvimentista pela doutrina de interdependência. A chamada revolução não aconteceu, o que de fato ocorreu foi uma ruptura no âmbito político, quanto ao contexto socioeconômico não houve uma ruptura mais sim uma progressão. (SAVIANI, 2008).

\footnotetext{
86 “As políticas da pós-graduação no Brasil, como as demais políticas educacionais, circunscrevem-se nas múltiplas determinações subsumidas pela sociabilidade do capital. Com base em tal hipótese, e possível levantar uma série de indagações sobre quem e como se determina a hegemonia nas politicas de pós-graduação e nas instituições que representam os pesquisadores em suas respectivas áreas do conhecimento. Questiona-se: em que medida essas políticas atuam, ou são determinantes, no fazer ciência dos pesquisadores? Com quais outros processos elas se articulam? Quais os movimentos que estabelecem uma dada hegemonia na produção do conhecimento no Brasil? [...]” (ÁVILA, 2008, p. 77).

${ }^{87}$ Segundo Saviani (2008a, p. 293) "De fato, em 1960, o modelo havia cumprido suas duas etapas: a primeira, correspondente à substituição dos bens de consumo não-durável (como, por exemplo, as indústrias têxteis e alimentícias), que, por não requerer grandes somas de investimento, foi possível instalar mais rapidamente, com base em capitais nacionais; e a segunda, referente à substituição dos bens de consumo durável (indústrias automobilísticas, eletrônicas, eletrodomésticas), cujas somas vultosas de capitais requereram o concurso das empresas internacionais. Completou-se, assim, o ciclo da substituição das importações: já não dependíamos mais das manufaturas trazidas do exterior. A meta da industrialização havia sido atingida. Logo, não fazia mais sentido lutar por ela. O que se ocultava sob o objetivo comum (a contradição de interesses) veio à tona quando o objetivo foi alcançado."
} 
Com a manutenção da ordem socioeconômica algumas reformas que aconteceram na Ditadura Militar ${ }^{88}$, "ditadura da burguesia fardada", impactaram diretamente a educação, educação fundamental e educação superior ${ }^{89}$, pois os ajustamentos educacionais estavam sujeitos aos ditames do capitalismo e as articulações se davam a partir da doutrina de interdependência. (SAVIANI, 2008). A partir dessa contradição entre modelo econômico e político, o contexto social que se desenvolveu foi marcado pelo autoritarismo e pela concentração de renda nas mãos de uma minoria da população acentuando a exclusão social. Portanto,

[...] as etapas de uma brutal intervenção do Estado no processo de formatação urbano-industrial da sociedade brasileira. Esse mais de meio século da historia republicana assistiu a uma gama extremamente complexa de um conjunto de contradições entre a velha ordem agrária, herdada das estruturas socioeconômicas do período colonial, bem como o nascimento lento e gradual da sociedade urbana assentada no entorno dos bolsões geográficos industriais. A rápida modernização que a sociedade brasileira viveu nesses decênios do século XX não representou, contudo, uma ruptura radical com o nosso passado de país periférico do sistema capitalista mundial. [...] a modernização autoritária da sociedade brasileira foi marcada pela descontinuidade sem ruptura, processo no qual muda-se uma ordem institucional conservando-se elementos estruturais da anterior (FERREIRA Jr. e BITTAR, 2006a, p. 21).

As marcas da ditadura da burguesia fardada permanece até hoje, no que diz respeito às políticas educacionais as mudanças ocorreram em todos os níveis de ensino, contexto em que a educação foi utilizada como aparato ideológico para propagação da ditadura, sendo assim, “[...] Essa ideologia era a tecnocrática que sustentava uma concepção pedagógica autoritária e produtivista na relação entre educação e mundo do trabalho”. (SACARDO, 2012, p. 89).

Segundo Saviani (2008) a partir desse 'modelo' de educação que foi instituído, sua base de orientação e sustentação correspondia a 'teoria do capital humano', teoria essa que focava a racionalidade, eficiência e produtividade; pregando o "máximo de resultado com o

\footnotetext{
${ }^{88}$ Segundo Húngaro (2010, p. 135) a denominação "ditadura da burguesia fardada" é mais adequado do que "ditadura militar", isso por dois fatores: $1^{\circ}$ os interesses da burguesia internacional financiaram o golpe militar em toda a América Latina e $2^{\circ}$ nem todos os militares foram condizentes e contribuíram com a tomada do poder;

${ }^{89}$ Segundo Ávila (2008, p. 78) “A constituição da pós-graduação, como nível de ensino, só foi possível a partir de uma serie de acontecimentos que a antecederam. Em 1951, foram criados, com diferença de poucos meses, o Conselho Nacional de Pesquisas (CNP)75 e a Campanha Nacional de Aperfeiçoamento de Pessoal de Nível Superior (CAPES) ${ }^{76}$. Segundo Spagnolo (1995, p. 9) já em 1952 a CAPES concedeu suas duas primeiras bolsas de aperfeiçoamento no exterior, numero que se ampliou nos anos subsequentes, respectivamente, para 54 e 72 . Neste primeiro período em torno de $60 \%$ das bolsas foram concedidas para o exterior. O primeiro núcleo institucional para estudos pós-graduados ocorreu a partir de iniciativas de dimensões limitadas, em que professores estrangeiros que aqui chegavam (seja mediante missões acadêmicas ou foragidos da II Guerra Mundial), estabeleciam uma relação tutorial (professor catedrático e um pequeno numero de discípulos) baseada no sistema de cátedra que se amparava no Estatuto das Universidades Brasileiras, de 1931”.
} 
mínimo de dispêndio" e "não duplicação de meios para fins idênticos". Essa teoria era sustentada pelo produtivismo fundamentada na pedagogia tecnicista “[...] alcançando todas as escolas naquele período, e, mais recentemente, aparece sob uma versão de ênfase na qualidade social da educação (orientando a nova LDB e o PNE - 2001)”. (SACARDO, 2012, p. 89.).

\begin{abstract}
A política educacional do regime militar abrangeu, ao longo dos seus vinte e um anos de duração, todos os níveis de ensino, alterando a sua fisionomia e provocando mudanças, algumas das quais visivelmente presentes no panorama atual. Pautado pela repressão, o Estado editou políticas e práticas que, em linhas gerais, redundaram no tecnicismo; na expansão quantitativa da escola pública de $1^{\circ}$ e $2^{\circ}$ graus às custas do rebaixamento da sua qualidade; no cerceamento e controle das atividades acadêmicas no interior das universidades; e na expansão da iniciativa privada no ensino superior. Reexaminando o conjunto dessas políticas, podemos afirmar que a educação, tal como ocorrera na ditadura Vargas (1937-1945), porém, em maior escala, foi totalmente instrumentalizada como aparelho ideológico de Estado. Sob uma ditadura que perseguiu, prendeu, torturou e matou opositores, a escola foi um dos meios mais eficazes de difusão da ideologia que respaldou o regime militar. (FERREIRA Jr. e BITTAR, 2006a, p. 1161).
\end{abstract}

Para modernização da sociedade brasileira, os desenvolvimentos tecnológicos e científicos foram os 'alvos' do governo militar", nas universidades, além das mudanças estruturais muitas foram às mudanças que adotaram o modelo norte americano para organização das disciplinas e cargas horárias dos docentes ${ }^{91}$, além da institucionalização e valorização da pós-graduação, também espelhada no modelo norte americano e europeu. A institucionalização da Pós-Graduação ${ }^{92}$ se deu pelo parecer no art.69 da Lei n. 4.024 do dia

\footnotetext{
90 "Em suma: por meio da departamentalização e da matrícula por disciplina com o seu corolário, o regime de créditos, generalizou-se no ensino superior a sistemática do curso parcelado, transpondo para a universidade o parcelamento do trabalho introduzido nas empresas pelo taylorismo. Perpetrou-se, no ensino, a separação entre meios e objetivos; entre conteúdos curriculares e sua finalidade educativa; entre as formas de transmissão do saber e as formas de produção e sistematização do saber; entre o pedagógico e o científico. Teoricamente, os meios, os conteúdos, as formas de produção e sistematização do saber, o aspecto científico, ficaram sob a jurisdição do departamento. Os objetivos, as finalidades, as formas de transmissão do saber, o aspecto pedagógico, a cargo da coordenação de curso. Paradoxalmente, acentuou-se o divórcio entre o ensino e a pesquisa, no momento mesmo em que a reforma proclamava sua indissociabilidade. Na prática, a dependência da coordenação de curso em relação ao departamento, esvaziado este de preocupações pedagógicas, significou, em termos da estrutura do ensino, a subordinação dos fins aos meios. Tal conseqüência - é bom lembrar - está em perfeita consonância com a concepção que orientou a reforma universitária, guiada pelos princípios da racionalidade, eficiência e produtividade". (SAVIANI, 2008a, p. 304-305).

91 "Em suma, a estrutura universitária que nos foi legada pelo regime militar acarreta consideráveis dificuldades à qualidade do ensino, determinadas pelos seguintes fatores: eliminação das turmas/classes resultante da departamentalização aliada à matrícula por disciplina e ao regime de créditos, dificultando o trabalho dos professores junto aos alunos e desconsiderando as especificidades das diferentes carreiras profissionais na programação das disciplinas que integram os respectivos currículos; substituição do período letivo anual pelo semestral, reduzindo o tempo de trabalho pedagógico do professor com seus alunos, o que inviabiliza a superação das eventuais lacunas e dificulta a assimilação efetiva, pelos alunos, dos conhecimentos constitutivos das disciplinas consideradas indispensáveis à sua formação". (SAVIANI, 2008a, p. 307-308).

${ }^{2}$ Segundo Ávila (2008, p. 79) "A pós-graduação recebe seu maior impulso, paradoxalmente, nos anos de chumbo da ditadura militar, sobretudo na fase do denominado "milagre econômico" (inicio da década de 1970),
} 
20/12/1961 (Lei de Diretrizes e Bases) em que foi solicitada ao Conselho Federal de Educação sua regulamentação por meio de sete tópicos: a origem e sua necessidade, o conceito, o exemplo da pós-graduação nos Estados Unidos e na Europa, a Pós-Graduação na LDB de 1961, a Pós-Graduação e o Estatuto do magistério, a definição e a caracterização da Pós-Graduação. (SACARDO, 2012). Somente em 1965 com o parecer nº 977/65, redigido por Newton Sucupira ${ }^{93}$, é que foram legitimados 38 cursos, 27 de mestrado e 11 de doutorado. Com esse parecer tornam-se nítidas as reais intenções e o modelo que seria adotado pela pósgraduação brasileira, "Entende o Sr. Ministro que esses cursos, destinados a formação de pesquisadores e docentes para os cursos superiores, deveriam fazer-se em dois ciclos sucessivos, 'equivalentes ao de master e doctor da sistemática norte americana', fixando o Conselho 'as exigências mínimas para sua realização e expedição dos respectivos diplomas ${ }^{, " 94}$, portanto,

Os objetivos principais da Pós-Graduação nesse parecer n. 977/65 seria a formação tanto de um corpo docente preparado e competente, quanto a formação de pesquisadores de alto nível e a qualificação profissional de outros do quadro técnico administrativo, necessários ao desenvolvimento nacional. Em um dos itens do parecer, em que a Pós-Graduação é inspirada no modelo norte-americano, seu ideário político dizia que "a nossa fragilidade científica era vista mais como causa do "atraso" do que como consequência de uma dependência mais ampla e de uma exclusão secular em matéria de educação nacional, especialmente, na escolarização básica." (SACARDO, 2012, p. 90).

Com a legitimação da pós-graduação em 1965, somente em 1966 que o governo deu início ao planejamento e desenvolvimento da reforma universitária, além da elaboração do Programa Estratégico de Governo e do $1^{\circ}$ PND (estes apresentados somente em 1972 e 1974). No Plano Educacional fazia-se menção as reformas: universitária e do ensino fundamental, além da consolidação da pós-graduação brasileira. Nesse processo de tentativa de reorganização da educação brasileira, com foco na educação superior somente com a

pois foi possível uma aliança tácita entre as elites militares e as elites acadêmicas - reconhecida na historia como um governo civil-militar, que gerou inúmeras contradições. Ambas vislumbravam um projeto nacional de desenvolvimento cientifico e tecnológico para garantir a autonomia nacional".

93 Segundo Ávila (2008, p. 79) "Vale lembrar que este parecer da prosseguimento a resoluções e outros pareceres, inclusive entre estes temos mais três que tiveram como relator, Newton Sucupira, o n ${ }^{\circ} 77 / 69$, o CFE $n^{\circ}$ $1683 / 74$ e o $n^{\circ}$ 08/75. Dentre estes, foi o parecer $n^{\circ} 77 / 69$ que estabeleceu os procedimentos, requisitos e condições para o credenciamento dos cursos de Pós-graduação".

${ }^{94}$ O Parecer encontra-se publicado na seção Documento da Revista Brasileira de Educação, no 30 , número especial, 2005. 
[...] reformulação das políticas setoriais, com destaque para a política de ensino superior e a de ciência e tecnologia, a Capes ${ }^{95}$ ganha novas atribuições e meios orçamentários para multiplicar suas ações e intervir na qualificação do corpo docente das universidades brasileiras. Com isso, tem papel de destaque na formulação da nova política para a pós-graduação, que se expande rapidamente. (CAPES, 2016).

A estrutura organizacional da pós-graduação stricto sensu e a sua hierarquização: mestrado e doutorado foram baseados em aspectos do modelo norte americano; quanto ao modelo europeu muitos foram os docentes que se apropriaram do mesmo, embora a legitimidade do nosso sistema perpasse a estrutura e organização norte americano. Enquanto nos Estados Unidos os alunos eram postos diante de uma estrutura bastante definida no ensino superior, enfatizando os aspectos técnicos operativos, já no que se refere a Europa os alunos se deparavam com certa autonomia intelectual, esperava-se do aluno a construção do trabalho por si, portanto, a ênfase se dava no aspecto teórico. (SAVIANI, 2008).

O modelo de pós-graduação adotado no Brasil seguiu deliberadamente a experiência dos Estados Unidos, como se pode observar no texto do Parecer. Nele se encontra um tópico com o seguinte título: "Um exemplo de pós-graduação: a norteamericana" (Brasil, 1965, p. 74-79). Foi com base nessa experiência que se definiu a estrutura organizacional da nossa pós-graduação stricto sensu, centrada em dois níveis hierarquizados, o mestrado e o doutorado, sem, porém, que o primeiro fosse requisito indispensável ao segundo. Isso significa que o mestrado poderia ser considerado como uma etapa preliminar para a obtenção do grau de doutor, ou como um grau terminal. De outra parte, a autonomia entre os dois níveis possibilitava, também, a inscrição direta no doutorado, sem a necessidade prévia da passagem pelo mestrado. Cada um desses níveis compreenderia o estudo de um conjunto de matérias relativas tanto à área de concentração, isto é, o campo de conhecimento constitutivo do objeto escolhido pelo candidato, como ao domínio conexo, ou seja, a área ou áreas de conhecimento correlatas e complementares àquela escolhida pelo aluno. O programa de estudos deveria se completar com a redação de um trabalho resultante de pesquisa, a dissertação, no caso do mestrado, e a tese, no caso do doutorado. A organização dos estudos proposta, embora procurasse pautar-se por

\footnotetext{
95 “A CAPES, fundação do MEC, desempenha papel fundamental na expansão e consolidação da pós-graduação stricto sensu (mestrado e doutorado) em todos os estados da Federação. [...] A Campanha Nacional de Aperfeiçoamento de Pessoal de Nível Superior (atual Capes) foi criada em 11 de julho de 1951, pelo Decreto $\mathrm{n}^{\circ}$ 29.741, com o objetivo de "assegurar a existência de pessoal especializado em quantidade e qualidade suficientes para atender às necessidades dos empreendimentos públicos e privados que visam ao desenvolvimento do país". Era o início do segundo governo Vargas, e a retomada do projeto de construção de uma nação desenvolvida e independente era palavra de ordem. A industrialização pesada e a complexidade da administração pública trouxeram à tona a necessidade urgente de formação de especialistas e pesquisadores nos mais diversos ramos de atividade: de cientistas qualificados em física, matemática e química a técnicos em finanças e pesquisadores sociais. [...] O ano de 1965 é de grande importância para a pós-graduação: 27 cursos são classificados no nível de mestrado e 11 no de doutorado, totalizando 38 no país”. (CAPES, 2016). Em 09 de Janeiro de 1992 a CAPES torna-se uma fundação pública por meio da Lei $n^{\circ} 8.405$, esta autorizou o poder público a instituir a Capes como Fundação Pública, o que confere novo vigor à instituição, condição essa instituída pela lei no 7.596 de 10 de abril de 1987, os determinantes de uma fundação consistem segundo o Art. $5^{\circ}$ inciso IV - Fundação Pública - a entidade dotada de personalidade jurídica de direito privado, sem fins lucrativos, criada em virtude de autorização legislativa, para o desenvolvimento de atividades que não exijam execução por órgãos ou entidades de direito público, com autonomia administrativa, patrimônio próprio gerido pelos respectivos órgãos de direção, e funcionamento custeado por recursos da União e de outras fontes”. (CAPES, 2016).
} 
grande flexibilidade, era bastante clara e envolvia tarefas bem especificadas, prevendo, inclusive, a figura de um diretor de estudos com a incumbência de assistir e orientar cada a um dos alunos. (SAVIANI, 2008a, p. 308-309).

Sacardo (2012) afirma que essas duas influências para sistematização do nosso formato de pós-graduação somaram até certo ponto, em primeiro lugar ajudaram na estruturação organizacional, em segundo lugar estimulou a uma busca pela densidade teórica, porém, o contexto político em que se encontrava o Brasil influenciava diretamente a pósgraduação, de forma tal que algumas áreas passam a atender não só as demandas estipuladas pela política mais também as econômicas, em contrapartida, foi pela institucionalização da pós-graduação que uma massa 'crítica' surge.

\begin{abstract}
Contudo, percebemos que apesar da existência de um Estado repressivo naquele momento histórico, esse estimulava a modernização de maneira acelerada em setores estratégicos a fim de o Brasil aderir aos valores capitalistas. Assim, tais estratégias são impregnadas de contradições, pois ao buscar atender determinado modelo de desenvolvimento, almejando controlá-lo, de certa forma, não o conseguem, uma vez a Pós-Graduação enquanto espaço privilegiado de produção do conhecimento haver contribuído tanto no caso da Educação como na Educação Física para o desenvolvimento de uma massa "crítica" que, "gerando estudos consistentes a contrapelo da orientação dominante, alimentou um movimento emergente de propostas pedagógicas contra-hegemônicas" (SAVIANI, 2008b, p.310). E muito mais do que promover a pesquisa e formar professores para o ensino superior, transformou-se em um espaço para produção de um pensamento autônomo, capaz de fazer a crítica do regime de governo que a criou, como argumentaram Coelho e Hayashi (2011), de modo a justificarem a metáfora do título do artigo "Zona Franca de Produção do Conhecimento". (SACARDO, 2012, p. 92).
\end{abstract}

Percebe-se que a influência da política e do capitalismo nas mudanças educacionais e na constituição da pós-graduação se tornou latente, o chamado "milagre brasileiro" tomou forma deturpando a realidade, ofuscando as contradições, mascarando as reais necessidades daquele período. Slogans ufanistas foram utilizados para coagir e coibir aqueles, principalmente os intelectuais, que desacreditavam daquela forma de governo, totalitária e autoritarista. A legitimação da pós-graduação nesse contexto contribuiu para a formação crítica e em contrapartida ajudou a 'alavancar' com o tão vangloriado milagre brasileiro, isso em termos de produção e sistematização de pesquisas. Embora a CAPES tenha sido legitimada anteriormente, nesse período a instituição ganhou destaque em prol do slogan "Brasil Potência".

Com a adaptação da economia ao capitalismo de mercado, as 'reinvindicações' por reformas nas universidades começaram a surgir, juntamente com a resistência a ditadura desembocando na crise de 1968. Os estudantes, orientados pela ideologia nacional desenvolvimentista ocuparam as universidades em junho de 1968 e deram início em cursos- 
pilotos, em algumas universidades assumiram durante todo o segundo semestre, em meio a este conturbado contexto em 2 de julho de 1968 o decreto 62.937 instituiu o GRTU, se tornando declarado o confronto entre movimento estudantil e o governo militar. A partir daí começaram as reformas de ensino instituídas pelo governo militar, o ensino superior foi à primeira reforma educacional a ser estabelecida e

[...] Foi diante desse contexto, que no ano de 1969, a partir do Decreto n. 464, de 11 de fevereiro, entrou em vigor a reforma universitária instituída pela Lei n. 5.540, de 28 de novembro de 1968, como um produto típico do regime instaurado. Foi aprovado também nesse mesmo dia, o Parecer CFE n. 77/69 que regulamentou a implantação da Pós-Graduação. (SACARDO, 2012, p. 90).

A partir de então a CAPES passa a estabelecer condições para o funcionamento das pós-graduações nas mais diversas áreas, iniciativas ${ }^{96}$ foram estabelecidas para o "progresso da ciência' e da 'produção do conhecimento'. Em meio esse processo, em 1976 a CAPES instituiu a avalição da pós-graduação, com o intuito de contribuir ainda mais para o progresso da ciência e desenvolvimento da produção científica, os objetivos dessa avaliação são;

[...] estabelecer o padrão de qualidade exigido dos cursos de mestrado e de doutorado e identificar os cursos que atendem a tal padrão; fundamentar, nos termos da legislação em vigor, os pareceres do Conselho Nacional de Educação sobre autorização, reconhecimento e renovação de reconhecimento dos cursos de mestrado e doutorado brasileiros - exigência legal para que estes possam expedir diplomas com validade nacional reconhecida pelo Ministério da Educação, MEC; impulsionar a evolução de todo o Sistema Nacional de Pós-graduação, SNPG, e de cada programa em particular, antepondo-lhes metas e desafios que expressam os avanços da ciência e tecnologia na atualidade e o aumento da competência nacional nesse campo; contribuir para o aprimoramento de cada programa de pós-graduação, assegurando-lhe o parecer criterioso de uma comissão de consultores sobre os pontos fracos e fortes de seu projeto e de seu desempenho e uma referência sobre o estágio de desenvolvimento em que se encontra; contribuir para o aumento da eficiência dos programas no atendimento das necessidades nacionais e regionais de formação de recursos humanos de alto nível; dotar o país de um eficiente banco de dados sobre a situação e evolução da pós-graduação; oferecer subsídios para a definição da política de desenvolvimento da pós-graduação e para a fundamentação de decisões sobre as ações de fomento dos órgãos governamentais na pesquisa e pós-graduação (CAPES, 2016).

\footnotetext{
96 “[...] a criação do PICD (Programa Institucional de Capacitação de Docentes), em 1976, programa que possibilitou a concessão de bolsas de estudos a professores universitários, os quais, mantendo seu salário integral, puderam dedicar-se a seus estudos pós-graduados nos principais programas de pós-graduação no país e no exterior, o que assegurou a formação de um expressivo contingente de quadros para a pesquisa e a docência na pós-graduação. Outra importante medida da CAPES, nesse contexto, foi o estímulo a criação de Associações Nacionais de Pesquisa e Pós-Graduação por área de conhecimento, muitas das quais, poucos anos mais tarde, viriam a se juntar ao movimento crítico nacional reivindicando mudanças no sistema político e educacional". (MORAES, 2006, p.193).
} 
Com o incentivo da CAPES a partir da concessão de bolsas, foi garantida a formação dos quadros de docentes e o apoio à formação continuada dos pós-graduandos, segundo Ávila (2008) esse percurso do pós-graduando era sistemático e não era acelerado, no contexto das ciências humanas somente após a integralização dos créditos eram definidos o objeto da pesquisa e o orientador, portanto "[...] esse processo era longo, mas viabilizou muitas dissertações com caráter de teses”. (Ibidem, p.80).

Atualmente o contexto da pós-graduação perpassa uma lógica acelerada e produtivista, lógica essa que atende as demandas do capitalismo tardio que desemboca na crença da solução tecnológica,

\begin{abstract}
A crença na onipotência da tecnologia é a forma específica da ideologia burguesa no capitalismo tardio. Essa ideologia proclama a capacidade de que tem a ordem social vigente de eliminar gradualmente todas as possibilidades de crise, encontrar uma solução "técnica" para todas as suas contradições, integrar as classes sociais, rebeldes e evitar explosões políticas. (MANDEL, 1982, p. 351).
\end{abstract}

Essa crença tecnológica se faz nítida nos PNPGs ${ }^{97}$. O I PNPG foi constituído em 1975 com vigência até 1979, este foi um marco na constituição da pós-graduação brasileira, pois, demarcou a necessidade da 'qualificação' dos docentes para o ensino superior brasileiro, além da demarcação da pós-graduação dentro do contexto da universidade. Nesse plano também houve a proposição de um planejamento estatal que alinhavasse e articulasse o

${ }^{97}$ O I PNPG (1975-1979) foi elaborado no governo do Presidente Ernesto Geisel, o Ministro da Educação e Cultura nesse período foi Ney Braga. O II PNPG (1982-1985) foi elaborado no governo do Presidente João Baptista de Oliveira Figueiredo, o Ministro da Educação e Cultura nesse período foi Esther de Figueiredo Ferraz. O III PNPG (1986-1989) foi elaborado no governo do Presidente José Sarney, o Ministro da Educação nesse período foi Jorge Bornhausen. No período do governo do Presidente Fernando Henrique Cardoso (1995-2003), o Ministro da Educação e Desporto foi Paulo Renato Souza o IV PNPG não foi publicado no formato dos anteriores, as publicações oficiais referentes às mudanças no ensino superior e na pós-graduação eram feitas por meio do INFOCAPES, esse processo descontínuo ocorreu segundo Ávila (2008, p. 81) "[...] em 1990, a CAPES passa por um período turbulento, que tem como ápice sua extinção, neste mesmo ano, embora temporária. $O$ período que enfocamos caracteriza-se justamente pela ausência oficial de um IV PNPG, mesmo tendo-se em vista que várias medidas foram tomadas nesse período como: a mudança na sistemática da avaliação dos programas (consubstanciada em uma avaliação do processo de avaliação dos programas desenvolvida pela CAPES, feita por consultores internacionais); a regulamentação do mestrado profissionalizante; e o financiamento passa a ser atrelado a produtividade dos programas (o tempo médio de titulação e um critério mais valorizado). Somando-se a essas medidas as reformas impostas ao Estado, evidencia-se uma mudança significativa no modelo de avaliação e da própria formatação da Pós-graduação brasileira". O V PNPG (2005-2010) foi elaborado no governo anterior ao governo do Presidente Luiz Inácio Lula da Silva e somente obteve aprovação na gestão do mesmo, o Ministro da Educação nesse período foi Tarso Genro. O VI PNPG (2011-2020) foi elaborado no governo da Presidenta Dilma Rousseff, o Ministro da Educação nesse período (período a que nos referimos foi à elaboração do PNPG, pois, o documento permanecerá em vigência até 2020) foi Fernando Haddad. Entendemos que essa contextualização é fundamental, pois acreditamos que a realidade é um todo articulado e as determinações de cada documento influenciou naquele momento e consequentemente influencia atualmente. 
desenvolvimento social com o econômico, como forma de demonstrar preocupação com a formação dos professores foi nessa época criado o PICD.

\begin{abstract}
Este documento, Plano Nacional de Pós-Graduação - PNPG -, é a expressão dos trabalhos iniciais do Conselho Nacional de Pós- Graduação, instituído no Ministério da Educação e Cultura pelo Governo Federal, através do Decreto nº 73.411 , de 4 de janeiro de 1974. Tanto a criação do Conselho como a elaboração do Plano são decorrentes de providências sugeridas no relatório do grupo de trabalho da Secretaria-Geral do Ministério da Educação e Cultura, que durante o ano de 1973 se constituiu para propor as medidas iniciais para a definição da política de pósgraduação. (BRASIL, 1975, p. 5).
\end{abstract}

Portanto, o objeto desse plano perpassou as atividades desenvolvidas nas instituições de ensino superior e nas instituições de pesquisa, visando à ampliação e o aperfeiçoamento da pós-graduação brasileira.

O II PNPG (1982-1985) objetivou qualificar o ensino na graduação e na pósgraduação brasileira. Segundo Ávila (2008) a CAPES buscou melhorar o contexto implementando algumas questões, "introduziu aprimoramentos nos formulários de obtenção de dados, bem como buscou sua progressiva informatização; criou as comissões de especialistas, uma para cada área de conhecimento e implementou a prática de visitas in lócus aos Programas.” (Ibidem, p. 80).

O objetivo central deste Plano consiste na formação de recursos humanos qualificados para atividades docentes, de pesquisa em todas as suas modalidades, e técnicas, para atendimento às demandas dos setores público e privado. Por recurso humano qualificado entende-se aquele dotado da capacidade de atuar na fronteira de uma especialidade, não só ao ponto de estar em condições de reproduzir o conhecimento que lhe é transmitido, o que apenas representa a capacidade efetiva de incorporá-lo, mas também de colaborar para o seu avanço, com contribuições significativas, o que representa o domínio real daquela especialidade. (BRASIL, 1982, p. 5).

Moraes (2006) salienta que neste período foi instituída a avaliação pelos pares, ou seja, a comunidade passou a participar ativamente desse contexto, de forma que passou a serem solicitados às áreas indicações de nomes para participação das comissões de avaliação. Percebe-se também nesse período a legitimação e solicitação de financiamento privado para manutenção da pós-graduação, portanto “[...] a existência de fontes múltiplas de financiamento, cuja atuação contribua para o êxito da Política Nacional de Pós- Graduação, é considerada um fator indispensável na complementação dos recursos orçamentários das instituições, no processo de implantação, desenvolvimento e maturação de um moderno complexo de pesquisa e pós-graduação”. (BRASIL, 1982, p. 6). 
No que se refere ao III PNPG (1986-1989), foi o primeiro da Nova República, e teve como foco a pesquisa, pela afirmativa do plano era fundamental o desenvolvimento da pósgraduação tanto em quantidade quanto em qualidade, isso para uma efetiva consolidação da pesquisa na pós-graduação.

\begin{abstract}
A conclusão mais importante é a de que o País não possui um quantitativo de cientistas que permita, a curto prazo, atingir plena capacitação científica e tecnológica. Torna-se, portanto, essencial iniciar, com a maior brevidade possível, um programa agressivo de formação de recursos humanos qualificados, tendo em vista que a sociedade e o governo pretendem a independência econômica, científica e tecnológica para o Brasil no próximo século. Assim é que o presente Plano Nacional de Pós-Graduação reafirma a política do governo de formar cientistas em quantidade, qualidade e perfis adequados ao modelo de desenvolvimento do País. (BRASIL, 1986, p. 5).
\end{abstract}

Porém, essa ofensiva não foi suficiente para superar a docência, evidenciando que as reais intenções do governo eram a independência econômica, tecnológica e científica, portanto, “[...] Dentro dessa perspectiva, a ênfase principal desse plano esta no desenvolvimento da pesquisa pela universidade e a integração da pós-graduação ao sistema de ciência e tecnologia”. (BRASIL, 2010, 14).

Quanto à efetivação do IV PNPG ${ }^{98}$, embora estivesse de certa forma organizado, algumas foram as circunstâncias políticas que influenciaram para que o documento não fosse publicado. O governo de Fernando Henrique Cardoso teve início em Janeiro de 1995, mais no governo de Itamar Franco foi traçado o Plano Real, o que permitiu-lhe a continuação dos ideias privatistas do Estado. Com tais características torna-se evidente o receituário neoliberal e o contexto de reestruturação produtiva.

É claro, portanto, que o objetivo real do capital monopolista não é a "diminuição" do Estado, mas a diminuição das funções estatais coesivas precisamente aquelas que respondem a satisfação de direitos sociais. Na verdade, ao proclamar a necessidade de um "Estado mínimo", o que pretendem os monopólios e seus representantes nada mais é que um Estado mínimo para o trabalho e máximo para o capital. (NETTO e BRAZ, 2011, p. 237).

\footnotetext{
98 "É preciso situar o IV PNPG no contexto mais amplo das orientações das políticas governamentais. Tais políticas - na forma de portarias, pareceres, resoluções e planos etc - estão completamente imbricadas a determinações sociais mais profundas "como as relações de classe, o lugar da educação na agenda da fração dominante e o grau de organização da classe que vive do próprio trabalho" (LEHER, 2004, p. 870). Segundo Leher um dos pressupostos evidentes no discurso dominante e o de que a educação quando "congruente com a revolução científica-tecnológica, permite inserir as nações da periferia e da semiperiferia no admirável mundo globalizado e de que todos os que fizerem opções educacionais corretas terão um futuro grandioso". Frente a isso ele questiona: "e a educação a nova riqueza das nações ou essa proposição faz parte de um processo de mercantilização e de ideologização da educação?" A chave desse mistério só pode ser desvendado se compreendermos a posição do governo frente ao conflito capital-trabalho, para então situarmos as medidas que afetam a educação superior ${ }^{94}$ e dentro dessas a política para a pós-graduação". (ÁVILA, 2008, p. 92).
} 
A flexibilização do trabalho, as mutações no processo tecnológico, a desregulamentação no processo produtivo foi mediado pelo Estado e regulado pelo capital, sendo assim a acumulação flexível e o toyotismo tomam forma deixando mais evidentes as características do capitalismo contemporâneo. Os professores do ensino superior expressaram sua compreensão acerca dos acontecimentos através de uma Carta no $14^{\circ}$ congresso do ANDES;

A redução do Estado fortalece a iniciativa privada, lógica que pode ser percebida nas reformas sobre a Ordem Econômica ao se propor o fim da diferença entre empresas brasileiras e estrangeiras para evitar a restrição ao Capital estrangeiro, flexibilização do monopólio da exploração do petróleo e a concessão de serviços de telecomunicação as empresas privadas. A concessão de serviço publico as empresas privadas e outra forma de "flexibilização", e um mecanismo importante de transferência de recursos públicos para os setores empresariais privados, na melhor tradição de capitalização privada dos lucros e de socialização das perdas (Carta do $14^{\circ}$ Congresso Nacional do ANDES, 1995).

Nesse contexto a pós-graduação ${ }^{99}$ brasileira é direcionada para a formação técnica e para o desenvolvimento de competências, de forma "[...] a incentivar a formação de quadros com um leque amplo de competências, capacitados para atuar nas complexas e múltiplas tarefas envolvidas na modernização estatal”. (INFOCAPES, 1995). Essas características ficaram nítidas nas metas de 1995, que eram as seguintes;

[...] a) interferir para diminuir o acentuado desequilíbrio regional, que concentra na região sudeste mais de $70 \%$ dos Programas de Pós-graduação ${ }^{84}$; b) Aperfeiçoar o Sistema Nacional de Avaliação dos Programas com a introdução de um elemento mais claro de aferição de um padrão de maior qualidade, através do qual podemos “... pleitear uma aproximação com os padrões de excelência internacional para aferir o desempenho de nossa pós-graduação, incorporando, em algumas áreas, nos comitês de avaliação, a participação de consultores externos." (Infocapes ${ }^{85}$, 1995, p. 12) Isso se refere às áreas que já possuem um padrão internacional, para as quais deveriam ser chamados especialistas estrangeiros nas próximas avaliações, com o objetivo de melhorar a inserção internacional dos programas; c) flexibilizar o modelo de pós-graduação, que além de manter como uma das prioridades a formação acadêmica, na direção de atender as demandas do mercado na qualificação profissional da área extra acadêmica, instituindo uma comissão de consultores que

\footnotetext{
${ }^{99}$ Em $1994^{81}$, último ano do Governo Collor - Itamar Franco já presidente, após o processo de impeachment de Collor -, a CAPES define uma politica de implementação de cursos de Pós-graduação, stricto sensu, aprovado pelo Grupo Técnico Consultivo (GTC), CAPES, na reunião de 13/09/94. Buscava-se a expansão do sistema da Pós-graduação redefinindo critérios para a abertura de cursos a serem recomendados ao Sistema Nacional de Cursos de Pós-graduação, com vista a avaliação e ao fomento. Neste documento manifestavam-se algumas preocupações correntes: desigualdade regional (concentração dos cursos na região sudeste); "formação de recursos humanos altamente qualificados, tanto para o setor acadêmico, como para os setores governamental e empresarial" (Infocapes82, 1994, p. 21); a carência de docentes e pesquisadores qualificados em nível de mestrado e doutorado; a necessária convergência entre a oferta espontânea de cursos novos e as necessidades prioritárias para o desenvolvimento do país; disponibilidade financeira e orçamentária para criação de cursos novos sem prejuízo aos já existentes; na avaliação garantir a qualidade acadêmica via consultores da própria área do curso.
} 
formulara um conjunto de recomendações - as quais, mais tarde, assumiram o formato do mestrado profissionalizante; d) intensificar a cooperação internacional "defendendo uma politica de fortalecimento de centros de excelência capazes de nuclear cooperação acadêmica de alto nível e a formação de recursos humanos em programas de pós-graduação regional.” (Idem, p. 13); e) avaliar os programas conduzidos pela CAPES, pois somente “... uma revisão destes critérios e a valorização da produtividade como elemento chave na distribuição de bolsas, aliada a um paulatino incremento do volume de bolsas do sistema, e que poderá viabilizar a continuidade e a expansão do sistema." (Idem, p. 14); f) dar continuidade aos programas da CAPES que estabelecem o vinculo com a graduação e lançar o "Programa de Formação de Recursos Humanos e Apoio a Reforma do Estado". A reforma do Estado e o principal ponto da pauta deste governo, sendo assim "este programa será concebido com vistas a incentivar a formação de quadros com um leque amplo de competências, capacitados para atuar nas complexas e múltiplas tarefas envolvidas na modernização estatal." (Idem, p. 15); g) rediscutir os critérios que devem orientar o tratamento e analise dos pedidos encaminhados ao GTC; h) ampliar o fomento a infra-estrutura dos programas de pós-graduação; i) intensificar a cooperação com outras agencias de fomento para resolução de problemas que possuem interface, como o CNPq e a FINEP. (ÁVILA, 2008, p. 84).

Percebe-se que a competitividade, a flexibilização e a elevação dos padrões nacionais e internacionais foram os norteadores dos princípios do documento, 'coincidentemente' foi nesse período que houveram mudanças nos padrões de avaliação da CAPES, bem como a criação do mestrado profissionalizante ${ }^{100}$, tais mudanças foram eixos do primeiro governo de Fernando Henrique Cardoso, essas mudanças nos paradigmas da avaliação aconteceram a partir de indicações para uma reforma da educação superior nos países em que o capital não estava tão em voga, o documento que legitimou essa reforma foi o relatório do BM de 1995, intitulado "La Enseñanza Superior: las lecciones derivadas de la experiência (El desarrolo en la práctica)". (SGUISSARDI, 2000). Vejamos a seguir as orientações do referido documento,

[...] Fomentar la mayor diferenciación de las instituições, incluido el desarrollo de instituciones privadas. Proporcionar incentivos para que las instituciones públicas diversifiquen las fuentes de financiamiento, por ejemplo, la participación de los estudiantes en los gastos y la estrecha vinculación entre el financiamento fiscal y los resultados. Redefinir la función del gobierno en la enseñanza superior. Adoptar políticas que ésten destinadas a otorgar prioridad a los objetivos de calidad y equidade [...]. (BANCO MUNDIAL, 1994, p. 4).

Com tais indicativos em 1996 com a elaboração do Programa de Apoio para o Desenvolvimento Científico e Tecnológico (PADCT III) a abertura para o setor privado no que diz respeito a pós-graduação se tornou ainda mais facilitado, tornando evidente a subsunção da vida social, acadêmica, as demandas do mercado. Independente da elaboração

100 “O mestrado profissionalizante e instituído através da Portaria n” 47 que resultou na Resolução 01/95. O argumento que baliza sua criação reveste-se do termo flexibilização para acatar as demandas do capital dentro da estrutura universitária, no nível da pós-graduação. O próprio documento da comissão, intitulado "Mestrado no Brasil - a situação e uma nova perspectiva" deixa claro os interesses a serem atendidos [...]”. (ÁVILA, 2008, p. 84). 
ou não do IV PNPG a CAPES altera o formato da avalição da pós-graduação, consolidando triênios subsequentes, o que acarretou significativas mudanças na política e nas concepções de ensino.

[...] o programa passa a ser a unidade básica da pós-graduação, substituindo a avaliação isolada dos cursos de mestrado e doutorado. Os destaques passam a ser para os cursos de excelência e a organicidade entre linhas de pesquisa, projetos, estrutura curricular, publicações, teses e dissertações. Em síntese, a finalidade da pós-graduação passa a ser produção de conhecimento e formação de pesquisadores, com ênfase avaliativa sobre os produtos, neste caso, a produção bibliográfica qualificada. Se a maioria dos doutores segue carreira acadêmica, como docentes, espera-se que sejam docentes pesquisadores. (ÁVILA, 2008, p. 88).

'Coincidentemente' essas mudanças ocorreram no mesmo período que o Banco Mundial, juntamente com o BID, BIRD e BNDE; apresentou um Relatório contendo determinações para mudanças no ensino superior dos países do Terceiro Mundo, segundo Ávila (2008, p. 99)

\begin{abstract}
Um dos argumentos do referido relatório, afirma Sguissardi, e que o modelo humboldtiano, da associação ensino-pesquisa-extensão, adotado no Brasil desde a Reforma Universitária de 1968, "com su estructura de programas em um solo nivel, ha demonstrado ser costoso y poco apropiado em el mundo em desarrollo" (1994, p.5; apud Sguissardi, 2000, p.57-58). Portanto, a solução e a diferenciação no ensino superior, por meio da criação de instituições não universitárias e instituições privadas que responderiam adequada e rapidamente a formação desse nivel com maior sensibilidade as necessidades das mudanças do mercado de trabalho. E justamente isso que a Lei de Diretrizes e Bases da Educacao Nacional (LDBEN), n. 9394/96, estabelece como mudanças para o Ensino Superior. Rompe a unidade universitária estilhaçando-a em varias outras possibilidades, inclusive os institutos superiores, que seriam instituições voltadas somente para o ensino, rompendo definitivamente com o modelo humboldtiano.
\end{abstract}

Em 1997 uma contribuição dos consultores internacionais expressou significativa mudança no contexto da pós-graduação brasileira,

No relatório final a comissão indica doze recomendações para aperfeiçoar o processo, divididas nos itens: politica de avaliação e processo de avaliação. Destacamos no primeiro item tanto a mudança da periodicidade da avaliação que passa a ser feita por triênios e não mais por biênios como vinha sendo feita, como a necessidade de se precisar o que significa cada conceito para todas as áreas, o que leva a mudança do conceito (A a E) para as notas (1 a 7). No segundo item, eles apontam a necessidade de visitas in loco aos programas e o tempo médio de titulação e as taxas de desistência como critérios que já são utilizados no mundo inteiro. Sugerem vinte novos indicadores para se avaliar os programas de forma mais qualitativa e reconhecem o esforço da Capes para que os programas brasileiros atinjam os padrões internacionais. (ÁVILA, 2008, p. 89). 
A partir dessas 'determinações internacionais', reflexo nítido do contexto neoliberal, em 1998 a CAPES lança dois programas: PROAP e o Programa de Fomento a Pós-graduação, ambos em caráter experimental e com propostas de melhoria nas condições de infra-estrutura dos cursos. Foi também nesse ano oficializado a troca dos conceitos para avaliação dos programas (1 a 5). Sendo legitimado janeiro de 1998 pelo INFOCAPES,

[...] Colocado em discussão o documento "Reformulação do Sistema de Avaliação da Pós-graduação: o modelo a ser implantado na avaliação de 1998”, que trata das principais inovações a serem implantadas na avaliação a partir deste ano: a avaliação por programas, baseada em padrões internacionais de qualidade; a mudança na escala de conceitos; e a não vinculação automática dos resultados ao sistema de fomento da Agencia. A avaliação devera, portanto, habilitar o programa a solicitar recursos a CAPES, para bolsas e custeio. (Ibidem, 1998, p. 56).

Essa nova proposta de avaliação passa a acompanhar anualmente os programas de pós-graduação, quanto a avalição, especificamente, essa foi modificada para trienal, [...] $a$ “Avaliação Trienal” propriamente dita, efetuada no ano subsequente ao do fechamento do triênio, momento no qual é atribuída a nota resultante do processo" (SILVA, 2013, p. 9394), na mesma medida em que passou a ser valorizada a pesquisa científica houve uma descentralização do foco da docência, o que se tornou uma preocupação latente atualmente, pois o produtivismo acadêmico expressa

[...] De um lado, a exacerbação quantitativista em que só se avalia o que pode ser mensurado, acarreta que "o modelo ganha dimensões formais que nem sempre expressam a realidade dos Programas.” (KUENZER; MORAES, 2005, p. 1348). Por outro, isso gerou um "verdadeiro surto produtivista em que o que conta é publicar." (ÁVILA, 2008, p. 90-91).

Baseado nisso a CAPES instituiu o QUALIS, elaborando um conjunto de procedimentos para estratificação da qualidade da produção intelectual dos programas de pósgraduação (CAPES, 2016). Segundo Patriarca (2012) no que se refere à qualidade, alguns fatores são questionáveis, pois os periódicos científicos são avaliados de acordo com a indexação das suas bases de dados e o fator de impacto ${ }^{101}$ das suas publicações, para além,

\footnotetext{
${ }^{101}$ Segundo Patriarca (2012, p. 109, Grifos da autora) "O fator de impacto é uma medida questionável e pouco confiável, pois é mensurado a partir da quantidade de citações que determinado artigo recebeu, não considerando se as citações foram em concordância ou como objeto de crítica. [...] o que resulta em 8 níveis, já bem conhecidos entre os professores da pós-graduação, são eles: A1, A2, B1, B2, B3, B4, B5 e C. Cada um desses níveis possui uma pontuação que, basicamente, irá fundamentar a avaliação dos professores e de seus programas: Estrato 7 (A1): 100 pontos, Estrato 6 (A2): 80 pontos, Estrato 5 (B1): 60 pontos, Estrato 4 (B2): 40 pontos, Estrato 3 (B3): 20 pontos, Estrato 2 (B4): 10 pontos, Estrato 1 (B5): 05 pontos, Estrato 0 (C): sem pontuação".
} 
Outro fator importante que merece destaque é o controle do tempo médio de titulação, que só pode ser visto como controle porque condicionou a política de concessão de bolsas ao resultado deste. Assim, ao mesmo tempo em que serviu para redimensionar os longos prazos de conclusão do mestrado e doutorado, também forjou o seu contrário: em particular, o aligeiramento do mestrado, considerado, agora, formação inicial em pesquisa a ser complementada no doutorado. Assim, a necessária redução nos tempos médios de titulação se sobrepôs, em grande medida, a qualidade da formação, principalmente no mestrado. [...] mesmo tendo em conta que elaborar uma dissertação deve constituir-se em exercício de autonomia acadêmica, pré-requisito indispensável para os estudos doutorais, o enfraquecimento desta primeira etapa põe em risco a qualidade da formação posterior (KUENZER; MORAES, 2005, p. 1349). (ÁVILA, 2008, p. 91).

Embora seja comprovado o desenvolvimento, a expansão e a consolidação da pósgraduação muitas foram às consequências posteriores dessas determinações de expansão. A política de ranqueamento que foi instituída facilitou as possibilidades de financiamentos “[...] e a flexibilização da pós-graduação, no sentido de reforçar a aliança entre Estado e Capital, com a introdução do mestrado profissionalizante" (Ibidem), na tentativa de internacionalizar os padrões para os programas, reforçando as condições de reforma do Estado naquele período.

Se a Lei 5.540/68 e os Pareceres 977/65 e 77/69, do antigo Conselho Federal de Educacao, tiveram grande importância na definição conceitual e na moldura legal da pós-graduação, os Planos Nacionais de Pós-graduação constituíram-se em outro elemento essencial na construção e desenvolvimento desse sistema. Os estudos para o IV Plano não fugiram a regra. Como nos demais PNPGs, evidencia-se ali o entendimento de que a pós-graduação e uma questão de Estado e que, nesse sentido, carece de uma direção macropolítica mediante a realização de diagnósticos e de estabelecimento de metas e de ações (KUENZER e MORAES, 2005). Desse modo, mesmo não tendo sido oficializado, os preparativos para a efetivação do IV PNPG serviram de pano de fundo para intensas e extensas ações da CAPES na pósgraduação brasileira.

Os documentos que orientaram a política de pós-graduação na década de 1990 direcionaram significativas mudanças como, a alteração no número de bolsas e a diminuição no tempo das mesmas, diminuição do tempo médio de titulação, reorganização e redefinição do mestrado com privilégio para o doutoramento além da vinculação de dissertações e teses aos projetos de pesquisa institucionais. Portanto, foi nesse período redimensionadas questões que influenciaram diretamente no V PNPG (2005-2010), como as mudanças no modelo de financiamento, a implementação do contexto de avaliação e orientações internacionais para 'legitimação do desenvolvimento, transformação e progresso da ciência'.

Sendo assim o V PNPG objetivava,

[...] o crescimento equânime do sistema nacional de pós-graduação, com o propósito de atender, com qualidade, as diversas demandas da sociedade, visando ao desenvolvimento científico, tecnológico, econômico e social do país. Esse Plano tem 
ainda como objetivo subsidiar a formulação e a implementação de políticas públicas voltadas para as áreas de educação, ciência e tecnologia (BRASIL, 2004, p. 54; grifo nosso). (BRASIL, 2004, p. 54).

A partir dessa evolução da pós-graduação brasileira o $\mathrm{V} \mathrm{PNPG}^{102}$ direcionou a expansão do Sistema Nacional de Pós-Graduação para quatro vertentes: 1) capacitação do docente para o ensino superior; 2) qualificação dos professores da Educação Básica; 3) especialização dos profissionais para o mercado de trabalho público e privado e 4) formação de técnicos pesquisadores para empresas públicas e privadas. (BRASIL, 2004).

Desse modo, para alcançar os objetivos do plano e atender às suas diretrizes, a CAPES formulou uma política de expansão do SNPG com base no princípio da indução estratégica, de tal modo que, em 2007, por meio da Portaria $\mathrm{n}^{\circ} 100$, de 24/10/2007, a CAPES regulamentou o PRONAP ${ }^{44}$. Assim, a partir dele, foi desenvolvido um conjunto de programas prioritários e especiais como estratégia para reduzir os desequilíbrios regionais, intrarregionais e entre estados, bem como integrar as políticas públicas de médio e longo prazo ${ }^{45}$. Nesse sentido, a CAPES, em 11/07/2007, foi reestruturada segundo a Lei $\mathrm{n}^{\circ} 11.502$ e, desde então, vem sendo chamada de "Nova CAPES", pois, além de coordenar o SNPG, também passou a induzir e fomentar a formação inicial e continuada de professores da Educação Básica. Tal atribuição foi consolidada pelo Decreto ${ }^{\circ}$ 6.755, de 29/01/2009, que instituiu a Política Nacional de Formação de Profissionais do Magistério da Educação Básica.

Para que as demandas do Decreto $\mathrm{n}^{\circ} 6755$ fossem atendidas, demandas essas que foram direcionadas para a formação continuada dos professores da Educação Básica, a CAPES assumiu as Diretorias de Educação Básica Presencial e a Distância, tais ações culminaram no Plano Nacional de Formação da Educação Básica, influenciando diretamente no contexto escolar, em menos de dois anos mais de trezentos mil professores foram atendidos. Nesse contexto em 2011 foi divulgado o VI PNPG (2011-2020) ${ }^{103}$ que pela primeira passou a integrar o PNE.

\footnotetext{
102 "Sumariando, os cinco Planos foram protagonistas de cinco importantes etapas na história da pós-graduação brasileira: 1 - a capacitação dos docentes das universidades, formando o primeiro contingente de pesquisadores e especialistas em âmbito federal; 2 - a preocupação com o desempenho e a qualidade; 3 - a integração da pesquisa desenvolvida na universidade com o setor produtivo, visando o desenvolvimento nacional; 4 - a flexibilização do modelo de pós-graduação, o aperfeiçoamento do sistema de avaliação e a ênfase na internacionalização; 5 - a introdução do princípio de indução estratégica, o combate às assimetrias e o impacto das atividades de pós-graduação no setor produtivo e na sociedade, resultando na incorporação da inovação no SNPG e na inclusão de parâmetros sociais no processo de avaliação. Destaca-se assim um forte componente de continuidade na gestão e na condução das atividades da agência face à sua missão institucional, aí incluída a efetiva participação comunidade científica". (BRASIL, 2011, p. 16).

103 “O Plano está organizado em cinco eixos: 1 - a expansão do Sistema Nacional de Pós-Graduação (SNPG), a primazia da qualidade, a quebra da endogenia e a atenção à redução das assimetrias; 2 - a criação de uma nova agenda nacional de pesquisa e sua associação com a pós-graduação; 3 - o aperfeiçoamento da avaliação e sua expansão para outros segmentos do sistema de C,T\&I; 4 - a multi- e a interdisciplinaridade entre as principais características da pós-graduação e importantes temas da pesquisa; 5 - o apoio à educação básica e a outros níveis e modalidades de ensino, especialmente o ensino médio". (BRASIL, 2011, p. 15).
} 
O Brasil ocupa, hoje, o $13^{\circ}$ lugar (ISI) em termos de número de artigos publicados. O SNPG está fortemente estabelecido e conta com a motivação de toda a comunidade científica. Por esse motivo, é possível vislumbrar que a adoção de uma agenda nacional de pesquisa arrojada associada com a mobilização da comunidade científica elevará, num médio prazo, a nossa ciência a um patamar de excelência que nos ermita não apenas antever novos saltos de qualidade, mas também caminhar para a obtenção do primeiro prêmio Nobel da ciência brasileira. (BRASIL, 2011, p. 23).

Percebe-se que o objetivo do VI PNPG (2011-2020), se apresentou de maneira semelhante aos anteriores quanto à internacionalização e a flexibilização do conhecimento, [...] o número alunos estrangeiros saltou de 934 a 2.278, ou seja, cresceu 144\%; mas esse número ainda é insignificante se comparado com o universo dos estudantes (BRASIL, 2011, p. 21), ao atingir a 'globalização' científica consequentemente o enquadramento nas metas de avaliações internacionais serão atingidas o que possibilitará a almejada excelência científica tecnológica, excelência essa que exercerá fortes influências no processo de financeirização acadêmica e consequentemente de programas de pós-graduação.

Tais características são expressões do capitalismo contemporâneo, portanto " $[\ldots] o$ grande capital quer impor uma desregulamentação universal - que vai muito além da “desregulamentação" das relações de trabalho”. (NETTO e BRAZ, 2011, p. 238), perpassa as relações acadêmicas e consequentemente a pós-graduação.

\begin{abstract}
A metodologia adotada na consecução deste Plano conduziu à criação de três Comissões, com funções diferentes, porém com ações articuladas e complementares: uma Comissão Nacional, com funções deliberativas, constituída por autoridades e especialistas, provenientes de órgãos de governo, universidades e da sociedade; uma Comissão Coordenadora, com funções de consultoria e apoio acadêmico; uma Comissão Técnica, com funções de suporte operacional (ver anexo: Portaria 36, de 05 de fevereiro de 2010) e Portaria 165 de 20 de agosto de 2010. (BRASIL, 2011, p. 13).
\end{abstract}

Essa metodologia de estruturação desemboca na "tríplice hélice", que envolve Estado, Universidade e Empresas,

[...]. Os resultados da pesquisa, ao serem aplicados, levam a tecnologias e a procedimentos, podendo ser usados no setor público e no sistema privado, e fazendo do conhecimento e da tecnologia uma poderosa ferramenta do desenvolvimento econômico e social. Neste quadro a parceria entre a Universidade, o Estado e as empresas dará lugar ao chamado modelo da tríplice hélice. Este modelo levará a colocar no centro do Plano, ou melhor, na sua base, aquilo que poderá ser chamado de Agenda Nacional de Pesquisa, com a participação de todas as agências de fomento federais e estaduais, com repercussão direta no SNPG e como matéria de políticas públicas, conduzindo a ações induzidas e a parcerias entre as universidades e os setores público e privado (BRASIL, 2011, p. 18). 
Essa lógica de organização perpassa a decadência ideológica, tanto o irracionalismo como a miséria da razão, pois, evidencia a eliminação das contradições do real, condições de segurança da realidade, a manipulação da vida privada e ampliação da racionalidade burocrática. "A possibilidade de desenvolvimento social mencionada no documento está vinculada ao desenvolvimento da ciência, não a garantia de direitos sociais, quanto às citadas 'parcerias' [...] atribui ao conhecimento uma lógica pragmática, de caráter utilitário, pois coloca a ciência a serviço do governo e de acordo com o modelo de desenvolvimento econômico e social proposto por ele”. (SILVA, 2013, p. 112).

\begin{abstract}
Nesse sentido, também é oportuno observarmos que essa lógica já vem se manifestando nas políticas de pesquisa e pós-graduação brasileira, desde os anos 1990, quando começaram os esforços pela diversificação e expansão da oferta dos programas, a flexibilização dos modelos de pós-graduação, a institucionalização de um processo contínuo de avaliação, o incremento da internacionalização, a cumplicidade com o mercado, a atuação em rede, a busca de perfis de excelência. Enfim, parafraseando o título da obra de Neves e Pronko (2008), há a formatação do mercado do conhecimento e as condições para produção de conhecimento para o mercado. Segundo Hostins (2006), trata-se da lógica corporativo-empresarial para a qual o conhecimento faz parte da economia, o que expõe o caráter expansionista do capitalismo, que, dirigido por suas leis internas de movimento, visa adentrar em todos os aspectos da vida social. Em outras palavras, a sociabilidade capitalista transforma o conhecimento num produto de importação e exportação, que assume um caráter de universalidade virtual, no qual todos são obrigados a se submeter às exigências da competição, da produtividade crescente e da internacionalização como forma ativa de responder à globalização do conhecimento ${ }^{49}$. (Ibidem, p. 112).
\end{abstract}

Articulado ao processo de reestruturação produtiva do mundo do trabalho (ANTUNES, 2009), podemos vincular a expansão dos cursos de pós-graduação, isso em função do atendimento das universidades ao sistema capitalista, tanto as instituições privadas quanto as instituições públicas, essa expansão dos cursos da pós-graduação se deu em função da quantidade de cursos de graduação que tem se disseminado devido à [...] exigência do "titulo stricto-sensu" para o credenciamento de universidades e recomendação de novos programas $^{50}$. (SILVA, 2013, p. 113).

Portanto, o contexto das reformas neoliberais que começaram em 1995 são reflexo até hoje, a reconfiguração do Estado brasileiro e o desenvolvimento do Brasil na América Latina influenciaram o desenvolvimento e as mudanças científica e tecnológica, isso devido a CAPES com a visibilidade de "liderança brasileira na região", passos esses direcionados para a formação para o trabalho no Brasil contemporâneo, com o desenvolvimento agrícola e a exportação de bens industriais o documento faz apontamentos sobre a necessidade de 
implementação e desenvolvimento de mestrados e doutorados que atendam as demandas dessas áreas específicas.

Essa ideologia legitima precisamente o projeto do capital monopolista do romper com as restrições sociopolíticas que limitam a sua liberdade de movimento. Seu primeiro alvo foi constituído pela intervenção do Estado na economia: o Estado foi demonizado pelos neoliberais e apresentado como um trambolho anacrônico que deveria ser reformado - e, pela primeira vez na história do capitalismo, a palavra reforma perdeu o seu sentido tradicional de conjunto de mudanças para ampliar direitos; a partir dos anos oitenta do século $X X$, sob o rótulo de reforma(s) o que vem sendo conduzido pelo grande capital é um gigantesco processo de contrareforma(s) destinado à supressão ou redução de direitos e garantias sociais. (NETTO e BRAZ, 2011, p. 237).

Foi a partir desse contexto neoliberal que o desenvolvimento da pós-graduação brasileira aconteceu, o Estado minimizou todos os entraves relacionados a possibilidade de prosperidade do sistema capitalista, ampliando a abertura para o financiamento privado, percebe-se que o mesmo aconteceu no contexto da universidade. Nos governos posteriores o que percebe-se é uma nova forma de governo que redesenhou a sociabilidade criando paradigmas a partir da instrumentalidade, adaptação e consenso. (SILVA, 2013).

Esse paradigma político foi adotado pela cultura política defendida pelo presidente Lula por meio de seu Pacto Social, que, até onde podemos observar, tem continuado no Governo da presidente Dilma. Para Silva Júnior (2005), no plano econômico, o Governo Lula seguiu a mesma política econômica do seu antecessor, cabendo assim ao seu governo tentar inovar nas demais políticas, em especial no modo de implantálas. Se no Governo FHC o diálogo era restrito, no Governo Lula ele tornou-se possível. Nesse sentido, Lula se aproximou do capital nacional com o intuito de fortalecer o capital produtivo industrial e o crescimento econômico brasileiro. Foi com base então em um status político e econômico mais forte, ao mesmo tempo em que se mostra subserviente às regras econômicas mundiais, o Pacto Social de Lula trouxe implicações para a política de ciência, tecnologia e inovação tecnológica e para a esfera educacional, mais precisamente para o nível superior (graduação e pósgraduação). (Ibidem, p. 114).

No que diz respeito à avaliação

Três eixos caracterizam a avaliação: 1- ela é feita por pares, oriundos das diferentes áreas do conhecimento e reconhecidos por sua reputação intelectual; 2- ela tem uma natureza meritocrática, levando a classificação dos e nos campos disciplinares; 3 - ela associa reconhecimento e fomento, definindo políticas e estabelecendo critérios para o financiamento dos programas. (BRASIL, 2011, p. 125).

Esse sistema de avaliação foi estabelecido em 1976, com o intuito de avaliar a produtividade dos cursos de pós-graduação que haviam se estabelecido e de avaliar as novas propostas para criação de novos cursos; ao longo desses anos dois foram os Sistemas de 
Avaliação da Pós-Graduação, inicialmente a classificação estabelecida era por letras, de A a E, os cursos que alcançavam padrão A se enquadravam nos padrões internacionais. A partir de 1997 passou a vigorar uma escala numérica de 1 a 7, os cursos que são avaliados com 6 e 7 se enquadram nos padrões internacionais. Os cursos que são avaliados com 'nota máxima' recebem uma ratificação mediante pareceres de consultores internacionais na tentativa de manutenção dos 'padrões internacionais'.

Percebe-se que a influência internacional no contexto da pós-graduação acontece em todos os âmbitos, desde a sistematização das políticas para consolidação da mesma e principalmente no que se refere à avaliação, pois é a partir do resultado dessa que são instituídos novos e programas e que são liberados financiamentos para a manutenção dos 'antigos' programas.

As avaliações se davam trienalmente ${ }^{104}$, por áreas 'afins' - a Educação Física está integrada a área 21, juntamente com a fonoaudiologia, fisioterapia e terapia ocupacional - a partir de uma comissão que é estabelecida mantendo membros do triênio/quadriênio anterior e indicação de novos membros para a composição da comissão de avalição dos critérios ${ }^{105}$, as análises desses critérios acontecem por meio do 'Acompanhamento Anual' e dos Fóruns Nacionais da Área 21, que resultam nos documentos de área. O VI PNPG afirma que

Certos parâmetros serão mantidos, como a escala numérica de 1 a 7 , com a nota 3 sendo considerado o padrão satisfatório para implantação. Outros parâmetros

\footnotetext{
104 “O Conselho Superior da CAPES, em sua 68a reunião, realizada no dia 11 de dezembro, decidiu que a avaliação do Sistema Nacional de Pós-Graduação (SNPG), a partir da próxima edição, passa a ser quadrienal. A decisão do colegiado foi tomada considerando a proposta apresentada pela Diretoria de Avaliação (DAV), acordada com a Comissão Especial de Acompanhamento do Plano Nacional de Pós-Graduação (PNPG) e com Fórum de Pró-Reitores de Pesquisa e Pós-Graduação (Foprop). A primeira avaliação quadrienal está prevista para ser realizada em março de 2017, versando sobre dados e informações dos anos 2013, 2014, 2015 e 2016 . O Conselho também aprovou a proposta de realização, no meio do período quadrienal, de uma análise que aponte tendências dos programas de pós-graduação. Esta análise será feita durante os "seminários de acompanhamento", que a DAV introduziu e passou a realizar desde o ano de 2011. Os 48 seminários de acompanhamento, em cada uma das áreas de conhecimento, do atual quadriênio, deverão ocorrer entre abril e junho de 2015". (CAPES, 2014).

${ }^{105}$ Os critérios de avaliação considerados são: 1- Proposta do programa corresponde a 0\% da avaliação total; 2- Corpo docente, $15 \%$ da avaliação corresponde ao perfil do corpo docente; 3 - Corpo discente, teses e dissertações, segundo Patriarca (2012, p. 107) esse critério “[...] analisa a quantidade e a distribuição das teses e dissertações defendidas no triênio em análise; tempo médio de titulação; fluxo de entrada e saída de alunos; existência de bolsa de doutorado sanduíche; dentre outros".; 4- Produção Intelectual, "Essa avaliação se dá a partir de instrumentos de pontuação da produção individual de cada docente - veremos a seguir - caracterizado pelo Qualis. Faz-se a somatória da pontuação de cada docente e divide-se pela quantidade de docentes permanentes do programa. "Pelo menos $80 \%$ dos docentes devem alcançar determinado patamar de pontuação compatível com o perfil de nota" (CAPES, 2009); além do registro de patentes e produções técnicas. É nesse critério que giram as principais polêmicas, pois, é aqui se define, fundamentalmente, a nota do programa, devido ao peso dado à produção [...] o instrumento de quantificação das publicações utilizado (Qualis) não é equânime para as diferentes áreas que compõem um mesmo programa" (Ibidem); por fim 5- Inserção Social, corresponde a $15 \%$ do valor total e releva o impacto regional do programa, além da integração e visibilidade para com outros programas.
} 
poderão ser conservados, como a nucleação e a solidariedade. Ao se manter o essencial do sistema atual, o PNPG estará reconhecendo o vigoroso papel que a avaliação por pares vem desempenhando no SNPG ao longo das décadas, a exemplo do que acontece nos outro países, mesmo naqueles que não contam com uma Agência coordenadora como a CAPES. Tal reconhecimento não desautoriza, porém, a exigência de introduzir novos parâmetros e procedimentos nos processos - tanto no sentido de aprimorar o modelo atual, quanto no de corrigir as distorções - havendo aquelas que induzem a um certo conservadorismo dos grupos, junto com a acomodação dos programas; e outras que levam ao produtivismo e à primazia da quantidade. Estando consolidado o sistema e universalizado a pós-graduação no país, é hora de se partir para metas mais ambiciosas nos conceitos: a meta poderá ser aumentar no decênio o número de cursos 7. (BRASIL, 2011, p. 22, Grifo nosso).

Nessa introdução do VI PNPG percebe-se os apontamentos no que diz respeito ao produtivismo, porém o que percebe-se adiante são contradições como o evidente privilégio das bolsas C\&T em detrimento das ciências humanas, pois, há uma supervalorização das ditas “ciências mães", desconsiderando a heterogeneidade do contexto da pós-graduação, tornando o 'Pacto Social' um pacto pragmático em função das demandas do capital, esse contexto nada mais é do que a miséria da razão, pois “[...] desempenha, seja ou não essa a intenção de seus realizadores, uma função reacionária: a de impedir que os homens rompam com a atual manipulação [...]” (COUTINHO, 2010, p. 98).

A partir dessa breve contextualização da real expressão da miséria da razão no PNPG que sistematizaremos os percursos da pós-graduação em Educação Física e as análises dos documentos de área, especificamente da área 21, apresentando as reais expressões da miséria da razão na realidade da pós-graduação em Educação Física. 


\section{CAPÍTULO III}

\section{A PÓS-GRADUÇÃO EM EDUCAÇÃO FÍSICA}

O terceiro capítulo irá apresentar uma breve contextualização histórica da pósgraduação em Educação Física para então apresentar as análises da documentação referente à área $21^{106}$, os documentos em voga serão os triênios 2001/2003; 2004/2006; 2007/2009; 2010/2012 e os relatórios de avaliação dos triênios 2007/2009 e 2010/2012 na tentativa de mediações com o referencial teórico construído para pontuar os vínculos com a decadência ideológica, com ênfase na miséria da razão, essa expressa pelo produtivismo acadêmico e consequentemente as especificidades no contexto da Educação Física.

\section{1 - Pós-graduação em educação física: determinantes históricos}

Ao pensarmos no contexto da origem e do desenvolvimento da Educação Física, percebemos que fortes foram/são os vínculos com a origem da burguesia enquanto classe, ou seja, sua origem está diretamente vinculada à virada da burguesia, de classe revolucionária para classe conservadora. Ao apontarmos as questões relacionadas à Modernidade, pretendíamos explicitar que este é um movimento de larga duração, que se divide em dois vieses: revolucionário e instrumental; portanto entendemos que a educação física perpassa também pelos dois momentos.

A origem embrionária da Educação Física moderna está nos sistemas ginásticos consolidados no século XIX na Europa que encontraram na escola um lócus propício para sua difusão por "Desenvolver e fortalecer fisica e moralmente os individuos [...]" e pelo "[...] seu caráter cientifico dado a partir do referencial oriundo das ciências biológicas [...]", (COLETIVO DE AUTORES, 2009, p. 52). A ginástica foi sendo configurada nas demandas advogadas pela classe social emergente, a burguesia, e pela organização do trabalho no modo de produção no qual ela se apoia.

O final do século XIX e o inicio do século XX foram imprescindíveis para o início da relação da ciência e da Educação Física. Período em que os fundamentos científicos dessa área baseavam-se preferencialmente no pensamento médicohigienista, ancorados, principalmente, nos conhecimentos biológicos, fundamentados pela concepção positivista de ciência. Tal pensamento, sobre

\footnotetext{
${ }^{106}$ A área 21 é formada por Programas de Pós-Graduação, sendo quatro as áreas (acadêmica e profissional) que a constituem: Educação Física; Fonoaudiologia; Terapia Ocupacional e Fisioterapia.
} 
influência europeia é o marco emblemático desse período, seja no contexto social, seja na própria Educação Física brasileira. (SACARDO, 2012, 52-53).

Os exercícios físicos e, mais amplamente, uma gama de saberes e práticas do corpo tem papel destacado na efetivação do novo projeto de homem (COLETIVO DE AUTORES, 2009; SOARES, 2004). Tanto na vida diária e, mormente, no mundo do trabalho, essa intervenção deve ser compreendida como um formato de educação corporal que integra o discurso do poder (SOARES, 2004). Os exercícios físicos fazem parte dos cuidados que educam o corpo, sendo neste expresso a força de trabalho e fonte de lucros, sendo exigido do trabalhador um corpo saudável, ágil e disciplinado.

A ginástica surge e se afirma na competência tutelada pelo exército através de certas técnicas e na instituição médica de quem recebe a autoridade de seu saber. Ela "[...] foi insistentemente solicitada a responder questões ligadas à ordem, à disciplina, à higiene. Esta demanda imprimiu-lhe uma face higiênica, moral, virtuosa” (Ibidem, p.118). Dessa maneira sua compreensão se dará a partir de normas e preceitos, modos de se comportar e regulação da consciência. (SOARES, 2004).

Nessa conjuntura, "O corpo, portanto, é objeto de conhecimento e de intervenção, é algo que se domina, é mensurável, é construção humana” (Ibidem, p. 46). A ginástica ${ }^{107}$ assume a função de manipulação numa visão mecanicista pertencente à racionalidade científica e nega a subjetividade, o sensível, a corporalidade espontânea e lúdica própria da vida e, também, das práticas corporais tradicionais das quais a ciência se apropriou e depois renunciou. Trata-se da inevitável subordinação da corporalidade a instrumentalização tão cara ao pragmatismo utilitarista burguês.

\footnotetext{
De fato, esta visão de ciência terá um papel peculiar para respaldar o ideário da burguesia em ascensão, fornecendo as bases que justificarão a visão de mundo dessa classe, além de sedimentar sua atuação no poder. Como esse modelo de conhecimento carrega em si uma natureza individualista, nele o indivíduo - sujeito que conhece - aparece como que isolado da sociedade e alheio a sua ação - aparece como ser independente da cultura. Tal modelo vai ocasionar um conjunto de teorias que passarão a justificar as desigualdades sociais pelas desigualdades biológicas, e, como tais, "desigualdades naturais". Portanto, "despreza o elemento sócio-histórico na determinação do sujeito que conhece, o que resta é um ser determinado pelas leis biológicas e cujas relações humanas não vão além daquelas que estabelecem a própria natureza" (SOARES, 2004, p. 8-9).
}

\footnotetext{
${ }^{107}$ Segundo Sacardo (2012, p. 54) "Esse tipo de entendimento reforçará o "esforço pessoal”, o individualismo, a valorização dos mais aptos, levando-os à competição exacerbada, o que ocasionará a exclusão dos menos aptos. Esses propósitos, inclusive, mantêm-se bastante atuais, visto mostrarem que o modo de ser e os valores burgueses daquele período ainda permanecem atuantes, porém com "novas roupagens". Além disso, a competição e a concorrência - os grandes motores do capital - serão entendidas como naturais, e não como produtos de um processo histórico de desenvolvimento da sociedade, como destacou Soares (2007)".
} 
No Brasil somente a partir da Segunda Guerra Mundial é que a Educação Física rompe com a lógica imbuída nos sistemas ginásticos quando começa a se relacionar diretamente com o esporte por meio do Método Desportivo Generalizado sendo isso a precedência do movimento de esportivização e da proeminência do paradigma da aptidão física e esportivo. O esporte moderno se torna hegemônico como um subproduto das relações capitalistas que reproduz princípios baseados na percepção do corpo-máquina primando pela eficiência técnica e máxima produtividade.

A partir da idéia de moldar uma moral cívica brasileira, o militarismo, principalmente na década de 1930, se apropria da educação física como viés de adestramento para a Segurança Nacional. "Pude assim dizer, estar à história da Educação Física no Brasil, se confundindo em muitos momentos com a dos militares" (CASTELLANI, 1991, p. 34). Mudanças conjunturais significativas (industrialização, urbanização e o estabelecimento de um Estado Novo - 1937) incidiram diretamente na vida do trabalhador, manipulando seu tempo livre e os condicionando para a vida social burguesa na tentativa de aumento da capacidade de produção.

Segundo Silva (2013) cinco foram os momentos da pós-graduação brasileira e da efetivação da pós-graduação em educação e em educação física no Brasil, são eles: 19311965, primeiras iniciativas da pós-graduação brasileira e da pesquisa nos campos acadêmicos da Educação e Educação Física; 1965-1974, a pesquisa e a pós-graduação institucionalizadas: a constituição do binômio pesquisa \& pós-graduação no Brasil; 1975 1989, expansão planejada da pesquisa e da pós-graduação no Brasil: o primeiro ciclo dos PNPG; 1990-2004, a pesquisa e a pós-graduação redesenhada e por fim, 2005 até os dias atuais, a pesquisa e a pós-graduação induzida: o segundo ciclo dos PNPGs.

No que se refere à pós-graduação em educação física, o período de 1931-1965 $^{\mathbf{1 0 8}}$ caracterizou-se pela inexistência de programas referentes à área, até mesmo porque, segundo Bracht (1999) a presença de outros campos sobre o campo da Educação Física (conhecida como ginástica escolar) era marcante, pois a efetivação da 'Educação Física' enquanto área não havia se legitimado.

\footnotetext{
108 Segundo Silva (2013, p. 55) “A primeira fase da pós-graduação brasileira compreende o período de 1931 a 1965 e caracteriza-se pela coexistência de modelos diferenciados de pós-graduação no país, bem como pela falta de centralização, controle e orientação por parte do governo em relação a esse nível de ensino. O marco de início dessa fase é a Reforma Campos, cuja instituição ocorreu em 1931, por meio do Decreto n $^{\circ} 19.815$, que previu pela primeira vez a realização de tais atividades no país, fornecendo também as bases jurídicas para que posteriormente a Faculdade de Filosofia, Ciências e Letras da Universidade de São Paulo - fundada em 1934 organizasse o seu doutorado. Ainda com essa Reforma, nos anos 1940, foi utilizado pela primeira vez, de modo formal, o termo "pós-graduação" no Artigo 71 do estatuto da Universidade do Brasil, conforme Decreto $\mathrm{n}^{\circ}$ 21.931/46 (SÁNCHEZ GAMBOA, 1996; SANTOS, 2003; SILVA, 1997)”.
} 
As características de formação de instrutores de ginástica, inicialmente, e de professores de EF, mais recentemente, fortemente marcada pela ideia de treinamento através da execução de movimentos, fizeram retardar o aparecimento do intelectual da EF. Não me refiro aqui ao intelectual no singular, mas, sim, ao agente social pertencente a um campo acadêmico capaz e instrumentalizado para construir teoria que fundamente a prática pedagógica em EF. Existem indicadores de que os intelectuais que pensaram a EF brasileira, nesse período, trouxeram/adquiriram o instrumental para tanto em outros campos, ou seja, o campo da "EF" não dispunha dos meios para teorizar sua prática [...]. (BRACHT, 1999, p. 18).

\title{
O período de $\mathbf{1 9 6 5 - 1 9 7 4}{ }^{109}$ foi marcado pelo Parecer 977/65, esse parecer estabeleceu
} três objetivos para progressão da pós-graduação: 1) compor um corpo docente capaz de atender as demandas de expansão do nível superior; 2) estimular do desenvolvimento da pesquisa a partir da preparação dos 'pesquisadores'; 3) propiciar treinamento para os técnicos de docentes do ensino superior elevando a qualidade e atendendo as necessidades do ensino. (BRASIL, 1965). A partir desses três eixos para a expansão da pós-graduação percebe-se a influência norte americana na orientação e organização do ensino superior no Brasil, a Pósgraduação foi dividida em dois níveis, mestrado e doutorado, quanto ao controle dos cursos o sistema de credenciamento foi adotado, mais uma característica norte americana.

\begin{abstract}
Assim, a influência americana na definição e caracterização do modelo de pósgraduação brasileiro não foi omitida em nenhum momento. Pelo contrário, o Parecer, inclusive, em um dos seus tópicos, é explícito ao intitulá-lo de: "Um exemplo de pós-graduação: a norte-americana", admitindo assim a utilização do modelo americano de pós-graduação para orientar a criação do Sistema Nacional de Pós-Graduação. No entanto, embora o Ministro da Educação e Cultura não tenha dado a devida consideração às atividades de pós-graduação já existentes no país, coexistiram dois modelos desse nível de ensino no Brasil (europeu e americano). Como a nova regulamentação definida pelo Parecer 977/65 estabeleceu princípios gerais de organização e funcionamento a partir do modelo americano, o que de fato ocorreu no país foi a estruturação de cursos de pós-graduação em dois níveis hierarquizados (o mestrado e o doutorado), conforme a experiência americana, mas com o "espírito" europeu, em virtude da influência europeia sobre os intelectuais
\end{abstract}

\footnotetext{
109 Segundo Silva (2013, p. 64) “[...] o período de 1965 a 1974 foi fundamental para a constituição do Sistema Nacional de Pós-Graduação, pois foi nesse período que ocorreu o processo de institucionalização da pesquisa e pós-graduação no país, constituindo o que Sánchez Gamboa (2003a) intitulou de "binômio pesquisa/pósgraduação". Segundo ele, os cursos de pós-graduação, stricto-sensu, concretizaram-se em espaços privilegiados pelo sistema educacional brasileiro para o desenvolvimento da pesquisa científica e tecnológica articulado a programas de formação de pesquisadores. Embora a institucionalização da pesquisa e pós-graduação no Brasil estivesse integrada a um conjunto de intervenções norte-americanas, via organismos internacionais (ONU, UNESCO, CEPAL, OEA, Banco Mundial, BID, União Panamericana) e outros mecanismos mais diretos como Aliança para o Progresso, Acordos MEC/USAID etc, basicamente tentaram impor na universidade brasileira dois tipos de influência: 1) a desintegração do padrão brasileiro de Escola Superior (universidade conglomerada); e 2) formação e consolidação de padrões de Ensino Superior, adaptado aos requisitos educacionais de uma sociedade competitiva e de massas (FERNANDES, 1979). No que se refere ao conhecimento produzido no âmbito dos cursos de pós-graduação no Brasil, Sánchez Gamboa (1998) e Silva (1997) afirmam que, se por um lado estes se enquadraram ao sistema político em vigor, por outro constituíram-se em oportunidades para crítica, denúncia e anúncio de novas possibilidades de rompimento com as políticas sociais e educacionais vigentes".
} 
brasileiros, em especial os das áreas de humanas (SAVIANI, 2008b). (SILVA, 2013, p. 60).

No que diz respeito à pós-graduação em Educação Física nesse período ainda inexistente, porém dois foram os movimentos desencadeados na área, o primeiro movimento [...] é a expansão dos cursos de graduação e o outro é a maior preocupação dos profissionais da área, principalmente aqueles ligados às Instituições de Ensino Superior (IES) com o status científico da Educação Física brasileira. (SILVA, 2013, p. 68). A possibilidade de formação continuada para os profissionais da área aconteceu pelas especializações, em nível de mestrado e doutorado somente em outras áreas ou no exterior.

\begin{abstract}
A respeito da preocupação com o status científico da Educação Física brasileira, identificamos duas motivações que se articulam nesse período histórico, a saber: uma de caráter externo à área, caracterizada pelos governos pós 1964, que viam na ciência e tecnologia os instrumentos necessários para elevar o desenvolvimento do Brasil. E a outra, de caráter interno à área, foi o desenvolvimento do esporte, como fenômeno mundial, que foi "utilizado pelo governo militar como marketing do Brasil como potência mundial do futuro". (SILVA, 2013, p. 69).
\end{abstract}

Com a forte influência militar e positivista, a imagem do Brasil foi se constituindo a partir da tendência tecnicista, de maneira tal que o objetivo era a formação de atletas para a conquista de medalhas olímpicas e excelência no futebol. Sendo assim o discurso pedagógico da educação física foi abafado pela suposta importância do desempenho esportivo, tornando as conquistas de medalhas o fator sociopolítico de maior importância para a época. (BRACHT, 1999).

\footnotetext{
Ainda sobre o desenvolvimento do fenômeno esportivo em nível mundial, Bracht (1999) observa que este contribuiu para que a área de Educação Física brasileira buscasse "teorizar" cientificamente o trabalho que vinha sendo desenvolvido por seus profissionais. Em outras palavras, os profissionais da Educação Física, perante a referida situação, precisavam mostrar que não apenas faziam uso de conhecimentos científicos, mas também eram capazes de produzir ciência, reivindicavam, assim, espaços que garantissem essa produção. (SILVA, 2013, p. 69).
}

Segundo Ávila (2008) nessa época, especificamente em 1974, alguns espaços de produção científica se legitimaram, como é o caso do Centro de Estudos do laboratório de Aptidão Física de São Caetano do Sul (CELAFISCS), este surgiu com o objetivo de promover e divulgar a abordagem esportiva científica, proporcionando formação em Ciências do Esporte. Sendo assim a produção científica da área foi direcionada para as biológicas, 
especificamente para o 'fenômeno esportivo', pois, a importância social dessa produção foi legitimada na ciência a partir desse investimento. (BRACHT, 1999).

\begin{abstract}
Por isso, podemos afirmar que o desenvolvimento do esporte, sob as bases políticosociais e econômicas nas quais se desenvolveu no Brasil, trouxe implicações ideológicas profundas para a área ao fortalecer uma determinada concepção de esporte, prática corporal e Educação Física em detrimento de outras concepções sobre os mesmos fenômenos citados. Assim, muitos profissionais da área, ao invés de se esforçarem no desenvolvimento de outras concepções e práticas, preferiram fundamentar o "teorizar de caráter cientificista" da Educação Física a partir das ciências-mães, como a biologia, a fisiologia, a psicologia etc. (SILVA, 2013, p. 70).
\end{abstract}

Segundo Bracht (1999) o profissional de Educação Física em busca de reconhecimento e legitimação da área torna-se um cientista vinculado a alguma especialidade e a subdisciplina, portanto, tornava-se um especialista em fisiologia do exercício, da sociologia do esporte e não um cientista da Educação Física.

Dessa forma, as décadas de 1960 e $1970^{110}$ foram cruciais para a Educação Física, pois o 'teorizar cientificista' começou a ganhar espaço, e consequentemente os investimentos para melhorar o nível de desenvolvimento técnico científico, a partir do déficit de investimento no âmbito da medicina esportiva alguns repasses fossem feitos, incentivando o progresso da pós-graduação e dos laboratórios de fisiologia. (BRACHT, 1999). Na década de 1970 uma nova entidade científica foi fundada, o Colégio Brasileiro de Ciências do Esporte (CBCE) ${ }^{111}$, tornando evidente a progressão do campo.

O período de 1975-1989 ${ }^{112}$ foi marcado pela construção do PNPGs, três foram constituídos nesse período, documentos que foram constituídos na tentativa de sistematizar os

\footnotetext{
110 "Os desdobramentos ocasionados durante a década de 1970 e a partir dos anos de 1980, refletiram numa indefinição e/ou numa "flutuação epistemológica" no dizer de Sanchez Gamboa (2007), em função do predomínio das subáreas, ora das ciências naturais (Fisiologia, Antropometria, Medicina Esportiva), ora das ciências humanas e sociais (Pedagogia, Sociologia, Antropologia, Filosofia), respectivamente". (SACARDO, 2012, p. 61).

111 "Em 1978, outro acontecimento importante foi à criação do Colégio Brasileiro de Ciências do Esporte (CBCE), "que objetivava pensar a problemática das ciências do esporte e buscava a construção e consolidação de seu campo acadêmico". Posteriormente, ou seja, em 1979, o CBCE lançou seu periódico científico, a Revista Brasileira de Ciências do Esporte (RBCE), órgão oficial de divulgação científica do CBCE e seu Congresso Brasileiro de Ciências do Esporte (CONBRACE) (ÁVILA, 2008, p. 59). Tais veículos de divulgação expressaram os interesses, os conflitos e o privilégio por uma concepção de ciência por aqueles que procuravam produzir conhecimento em Educação Física nas condições históricas concretas daquele período". (SACARDO, 2012, p. 60).

${ }^{112}$ Segundo Kuenzer e Moraes (2005, p. 1345) “A história mostrou que o I PNPG, além do mérito de reconhecer que a expansão da pós-graduação só seria exequível por uma política indutiva deliberada do Estado e de integrála ao sistema universitário, estabeleceu a centralidade da pós-graduação na formação docente. Com isto em vista, propuseram-se os programas de concessão de bolsas para alunos em tempo integral, a extensão do Programa Institucional de Capacitação Docente (PICD)4 e o apoio à admissão de docentes para atuar na pós-graduação nas Universidades. Foi fundamental a ação da CAPES5 nesse processo, da qual resultou uma efetiva expansão e institucionalização da pós-graduação. O financiamento para pós-graduandos por meio de bolsas de estudos,
} 
principais objetivos, normas e princípios para o incentivo dessa progressão e expansão, para além foram legitimados os incentivos privados para o progresso da ciência. Portanto, a pósgraduação, no contexto brasileiro, estava em processo de legitimação, os pareceres 977/65 e 77/69 impulsionaram sua expansão. A educação física também seguiu essa tendência, “[...] Assim, em 1977 e 1989113, foram criados, na USP, os primeiros cursos de mestrado e doutorado, respectivamente" (SILVA, 2013, p. 80), no período de 1975 a 1989 foram criados mais seis cursos de mestrado, somados com os cursos da USP totalizavam oito cursos de pósgraduação em Educação Física.

Essa fase caracterizou-se pela expansão dos cursos e pelo estabelecimento de normas e princípios (desempenho e qualidade aferidos por um sistema de avaliação) para a pós-graduação no país, especialmente a stricto-sensu, da qual foi exigida, primeiro, a capacitação dos docentes das universidades, em especial das federais, que estavam em expansão, e depois maior interação da pesquisa com o setor produtivo visando ao desenvolvimento nacional. (SILVA, 2013, p. 71).

Chegado o fim do "Milagre Brasileiro", aconteceu o processo de redemocratização e o reestabelecimento do movimento operário, isto em função de mudanças que foram significativamente influentes para a reorganização da política e do cenário social brasileiro. Como exemplo, temos: o dossiê "Brasil Nunca Mais", o movimento pela anistia, o fim do bipartidarismo, o surgimento de instituições representativas da classe trabalhadora, o movimento das “Diretas Já”, entre outras (HÚNGARO, 2010, p. 136).

Dessa maneira a crítica ao paradigma da aptidão física e esportiva ${ }^{114}$ foi aguçada pela inserção de discussões mais incisivas das ciências sociais e humanas na Educação Física

aliado ao PICD, assegurou a formação de um expressivo contingente de quadros, em particular para a docência na pós-graduação".

113 "Esse acontecimento foi influenciado pelo contexto sócio-político e econômico da época, e a implantação da pós-graduação promoveu um crescimento significativo dessa produção científica no período (SILVA, 2005). [...] A partir desse contexto, os "ânimos" por busca de reconhecimento e legitimidade acadêmica, a preocupação com o status científico na área, são atiçados, principalmente, por aqueles vinculados ao ensino superior. Isso levou alguns profissionais a buscarem qualificação em cursos de Pós-Graduação (mestrado) em programas da área da Educação, o que ocasionou, no início dos anos de 1980, mudanças nas reflexões dos profissionais da Educação Física. Independentes da matriz teórica utilizada, as discussões estiveram ancoradas pelas ciências humanas e sociais $^{15}$. Tais estudiosos chamavam a atenção às dimensões socioculturais e político-econômicas que se encontravam à margem dos estudos desenvolvidos na área da Educação Física até aquele momento". (SACARDO, 2012, p. 60).

${ }^{114}$ Segundo Sánchez Gamboa (2010, p. 27-28) “A Educação Física e outros campos do conhecimento, como a Pedagogia, a Educação Artística, a Políticas, a Ética, etc. encontram-se num patamar de desenvolvimento próximo à definição de seus campos epistemológicos no quadro geral das ciências. Todas as ciências hoje reconhecida pelos estatutos da Academia tiveram seu desenvolvimento próprio no contexto das formações e transformações da sociedade na qual têm significado e da qual obtêm os insumos necessários para o seu crescimento e sua independência em relação a outros campos do conhecimento, particularmente da Filosofia e das denominadas "disciplinas mães". Dificilmente a história se repete, segundo o hipotético processo de gestação, maturidade e independência. A história das ciências de cada uma das áreas, hoje com estatuto epistemológico próprio, não obedeceu a rituais analíticos de dividir as áreas em subáreas, nem à independência 
excita o surgimento de teorias críticas. Umas balizadas como práticas alternativas em tentativas de rupturas com esse paradigma em que a visão de corpo e de corporalidade estão sob os limites do biológico, do psicológico ou da motricidade humana - Psicomotricidade, Desenvolvimentista, Construtivista, Saúde Renovada, Jogos Cooperativos, PCN's e Humanista. E outras que buscam movimentos propositivos de intervenção perspectivando transformações na estrutura social - Crítico-Superadora, Crítico-Emancipatória e Concepção de Aulas Abertas.

\begin{abstract}
Assim, é perfeitamente possível localizar este período de ascensão do pensamento da Educação Física brasileira (que é aquela que nos interessa). A Educação Física estabeleceu, em seu processo de renovação, uma interlocução com a teoria social de cunho crítico sabidamente inspirada no pensamento dialético, cuja expressão original foi a de Hegel, na Modernidade. Marx, como sabemos, foi um herdeiro de Hegel - claro que superando suas elaborações (em sentido dialético). (PATRIARCA, 2012, p. 83).
\end{abstract}

Na tentativa de que a Educação Física acompanhasse o desenvolvimento do país a medida que estabelecida pelo GCE, DED e MEC foi a institucionalização do Mestrado na área, dessa maneira em 1977 o primeiro mestrado na área, no Brasil e na América Latina, foi instituído, seu quadro de docentes era composto por professores que foram titulados no exterior, tornando evidente o acordo MEC/USAID ${ }^{115}$.

É importante destacar que um dos passos mais importantes para a institucionalização da pós-graduação em Educação Física, em nível stricto-sensu, conforme a legislação em vigor, foi a criação do Grupo de Consultoria Externa (GCE), instituído pela Portaria $\mathrm{n}^{\circ}$ 168/75, do Departamento de Educação Física e Desporto (DED) do MEC, que tinha o objetivo de analisar a situação da educação física e propor medidas para implantação da pós-graduação na área. (SILVA, 2013, p. 80).

dessas subáreas, ganhando o reconhecimento da comunidade científica, numa cerimônia formal na qual teria sido entregue o diploma de maturidade epistemológica a cada ciência nova, o que lhe teria permitido abrir um espaço no controvertido e interesseiro campo da academia. [...] A Educação Física, assim como outras áreas que se encontram numa fase de definição epistemológica, progride na medida em que clareia seus campos nos interstícios do tecido atual dos saberes e na correlação de forças da conjuntura do desenvolvimento do mundo das ciências, mas, isso não é possível sem a pesquisa científica, a ação privilegiada nesse campo, e sem o exercício costumeiro da crítica rigorosa dos procedimentos e dos resultados que, na linguagem particular do mundo das ciências, é relacionado à Epistemologia.

115 Assim sendo, o modelo econômico após 1964, com o esgotamento do processo de "substituição de importações", assumiu progressivamente as características de capitalismo de mercado associado dependente, enquanto os estudantes universitários continuavam com a ideologia do nacionalismo desenvolvimentista. Contrários à ideologia dos estudantes, a ditadura Civil-Militar tomou várias medidas, como a Lei no 4.464/65 que regulamentou a organização e o funcionamento dos órgãos de representação estudantil e a assinatura dos Acordos do MEC com a Agência Norte Americana para o Desenvolvimento Internacional (USAID). Os Acordos MEC-USAID representaram parte das medidas repressivas que foram adotadas pelo Governo Militar e que tinham como finalidade, por um lado, enquadrar o sistema educacional regular na nova ordem econômicopolítica e, por outro, reprimir os movimentos de educação e cultura popular (SILVA, 1997, p. 33). (SILVA, 2013, p. 62-63). 
Com a criação do $\mathrm{CBCE}^{116}$, da RBCE e do COMBRACE os conflitos, os interesses e a tentativa do reconhecimento científico da área se tornaram evidentes, as produções científicas $^{117}$ na época se deram a partir de intensos debates sobre as condições epistemológicas e a tentativa de legitimidade científica da área, apresentando o que era a Educação Física e as propostas de mudanças para o contexto, mudanças essas que eram sugeridas por um quadro de professores que se qualificaram na área da Educação. Os questionamentos se davam em torno da hegemonia dos princípios biológicos, "[...] Tais estudiosos chamavam a atenção para as dimensões sociocultural e político-econômica que se encontravam à margem nos estudos desenvolvidos na área da Educação Física até aquele momento”. (SILVA, 2013, p. 82).

Até a primeira metade dos anos 1980 a Educação Física era predominantemente influenciada pela concepção positivista, já na segunda metade a institucionalização da pósgraduação na área influenciou diretamente o debate no que diz respeito à identidade epistemológica, segundo Gamboa (2010) teve início à "flutuação epistemológica", isso porque ora tínhamos a predominância das ciências chamadas de naturais, ora tínhamos a predominância das ciências chamadas humanas.

A preocupação com as questões teóricas e epistemológicas expressa a busca de uma nova forma de fazer pesquisa, ultrapassando a fase de "ciência aplicada" caracterizada pela apropriação simples de métodos e referências desenvolvidas em outras áreas e pelo "tomar emprestado", como vem acontecendo quando se

\footnotetext{
116 Segundo Silva (2013, p. 81) “O CBCE é uma das instituições científicas mais importantes do Brasil e da América Latina, particularmente da área de Educação Física/Ciências do Esporte. Filiado à SBPC, em seus 34 anos de existência, acompanhou e acompanha o desenvolvimento da área, participando ativamente do seu desenvolvimento e se tornando um grande veículo de divulgação, discussão e debate de grandes temas e produções que são ali desenvolvidas. É importante destacar que o CBCE teve e ainda tem papel importante na integração e intercâmbio de pesquisadores e na disseminação da pesquisa em Educação Física/Ciências do Esporte no Brasil e na América Latina. Conta com uma direção nacional e mais de 20 secretarias estaduais e 12 grupos de trabalho temáticos, sendo as duas últimas instâncias organizativas do colégio. O CBCE indica bem a expansão da pesquisa em Educação Física e Esportes nas instituições de ensino superior ou centros independentes, públicos ou privados. Isso pode ser constatado por suas reuniões anuais (intercalando de dois em dois anos os congressos regionais com os nacionais/internacionais), que têm congregado em torno de dois mil pesquisadores, com aumento sistemático de trabalhos submetidos à apreciação das comissões científicas do evento".

${ }^{117}$ Segundo Sánchez Gamboa (2010, p. 30) "Pesquisar a problemática em Educação Física não consiste apenas em utilizar instrumentos, realizar procedimentos, aplicar algumas teorias e método já desenvolvidos em outras áreas, especialmente nas denominadas "disciplinas mães” (Fisiologia, Biomecânica, Psicologia, Sociologia, etc.). Pesquisar implica a elaboração de referenciais teóricos específicos e do delineamento de opções epistemológicas condizentes com a natureza da área. Isto é, pesquisar não consiste em tomar emprestadas técnicas, métodos e teorias para descrever ou explicar problemas vinculados ao campo da Educação Física. Parece ser necessário definir pontos de partida e de chegada dos processos do conhecimento, de caminhos, das articulações entre processos e horizontes compreensivos, que fogem das recitas científicas e de paradigmas prontos e consolidados em outras áreas, por serem campos epistemológicos novos. Daí porque adquirem destacada importância as questões sobre a identidade epistemológica da área, a busca da especificidade do objeto, a redefinição de conceitos e a criação de novas denominações para identificar novas abordagens, ou mesmo, propor uma nova ciência".
} 
consolidam novas áreas do conhecimento [...]. À semelhança de outras áreas, a Educação Física sofre as flutuações do denominado "colonialismo epistemológico" das ciências mães. A Educação Física torna-se um campo colonizado onde são aplicados os métodos e as teorias dessas ciências mãe, denominando-se, por exemplo, Psicologia da Aprendizagem Motora, Sociologia do Esporte, Fisiologia do Esforço etc. (SÁNCHEZ GAMBOA, 2010, p. 31).

No contexto de redesenho da pós-graduação, 1990-2004 ${ }^{118}$, a Educação Física seguiu algumas medidas da CAPES, como a expansão e a implementação da pós-graduação; já no que diz respeito à internacionalização e a criação do mestrado profissional, foram medidas atendidas posteriormente.

[...] Quanto à expansão da PGEF, no período de 1990 a 2004, foram criados nove novos cursos de mestrado e cinco de doutorado, perfazendo um total de 14 cursos novos (Planilha dos PPGEF_Março de 2012_Evolução_Planilha PGE4). Portanto, em um período de 14 anos, a PGEF saltou de sete para 16 cursos de mestrado e de um para seis cursos de doutorado, o que representou um crescimento de $128,5 \%$ e 500\%, respectivamente. (SILVA, 2013, p. 105).

Adiante, com a análise dos documentos da área, perceberemos que esse aumento se tornou constante, além da tentativa da manutenção dos cursos na lógica da pós-graduação, ou seja, a tentativa de atendimento do sistema de avaliação pela produção acadêmica. Alguns paradoxos, perceptíveis até hoje, já eram notórios nesse período, um deles é a discrepância da distribuição regional de cursos de pós-graduação, as regiões sudeste e sul concentram maior parte dos cursos de pós-graduação enquanto as regiões nordeste e norte nessa época não apresentavam nenhum programa. Outro paradoxo, dessa época, enfatizado por Silva (2013, p. 105) corresponde ao "[...] aumento na produção de dissertações e teses da área sem o rigor científico exigido para trabalhos dessa natureza [...]”.

Nesse contexto, outra questão que se tornou evidente foi à diversificação epistemológica da Educação Física, pois dialogamos com diferentes disciplinas, anatomia, cinesiologia, psicologia, história, filosofia; essa diversificação ao invés de fortalecer e amadurecer a área tem se tornado pauta de extensos embates, argumentos tem sido utilizados para fortalecer e qualificar as tendências empírico analíticas em detrimento das outras subáreas. (Ibidem). Essas disputas se tornaram ainda mais acirradas após a implantação e modificação da avaliação por biênios (inicialmente 1997-1998) / triênios (2001-2012) Essa

\footnotetext{
118 "Essa quarta fase (1990-2004) caracteriza-se pela inexistência oficial do IV PNPG, embora tenham sido publicados, no boletim INFOCAPES ${ }^{22}$, várias ações realizadas pela CAPES nesse período como: a mudança no sistema de avaliação dos programas (sugerida por uma equipe de consultores internacionais contratados pela CAPES para avaliar sua sistemática de avaliação dos programas); a regulamentação do mestrado profissional; e a vinculação do financiamento à produtividade dos programas (com destaque para o tempo médio de titulação, que passou a ser mais valorizado)". (SILVA, 2013, p. 83).
} 
nova forma de avaliação ${ }^{119}$ da CAPES adotou os indicadores internacionais para estabelecer parâmetros a serem cumpridos, influenciando diretamente as subáreas da Educação Física, de maneira que as áreas que possuíam maior afinidade com tais parâmetros se sobressaíram em relação às demais.

\begin{abstract}
Uma evidência do que estamos argumentando é que a área enfrenta dificuldades para ser classificada nas tabelas das áreas de conhecimento das agências de fomento (CAPES e CNPq, por exemplo). Sendo assim, em virtude dessa dificuldade, a Educação Física é incluída como subárea na grande área de Ciências da Saúde, juntamente com a Fisioterapia, Terapia Ocupacional e Fonoaudiologia. Dessa forma, as pesquisas que possuem orientação diferente da grande área da saúde ficam prejudicadas, já que no Qualis ${ }^{120}$ periódicos da área da Educação Física não estão presentes os periódicos vinculados às áreas das Ciências Sociais Aplicadas e Ciências Humanas classificados como Internacional A ou B. Com isso, tanto os pesquisadores quanto a veiculação do conhecimento produzido na área saem prejudicados na busca por financiamentos junto às agências de fomento, limitando, consequentemente, o desenvolvimento da pós-graduação em Educação Física para outras áreas de concentração que não estejam afinadas com a área da Saúde. (SILVA, 2013, p. 106).
\end{abstract}

Com o déficit de cursos de pós-graduação nas regiões norte, nordeste e centro-oeste percebe-se uma migração dos professores/pesquisadores da área para as áreas das Ciências Humanas, principalmente no que se refere à Educação. A partir de $\mathbf{2 0 0 5}$ pelas análises dos documentos de área percebe-se que a avaliação da CAPES tem se dado de maneira positiva, acerca do crescimento e progressão da pós-graduação, e com os indicativos do que se faz necessário ser aprimorado para o triênio seguinte. A partir dessa breve apresentação do processo histórico da pós-graduação em Educação Física, a seguir apresentaremos as análises dos documentos de área da CAPES, esses expressaram a partir do levantamento de dados às

\footnotetext{
119 "Na realidade, o que pode ser observado é que essa avaliação é "duplamente indireta", dado que o que se leva em conta não são exatamente (e apenas) as revistas nas quais os artigos estão publicados, mas principalmente as bases de das nas quais eles são indexados". (STIGGER; SILVEIRA; MYSKIW, 2015, p. 33).

${ }^{120}$ Considera-se periódico científico aquele veículo que divulga resultados de investigações, que possui ISSN e fonte bibliográfica de referência (bases de indexação). Além da sua relevância social e acadêmica, o periódico necessita possuir qualidade editorial, a qual compreende: originalidade e qualidade dos artigos publicados, seleção de artigos por corpo editorial reconhecido na comunidade acadêmica da área e processo de avaliação por pares (peer-review). As listas ou bases indexadoras constituem fonte bibliográfica de referência, as quais permitem a democratização do acesso à produção científica da área e a respectiva visibilidade na comunidade acadêmica. A partir dos acordos estabelecidos na Grande Área da Saúde, adotou-se o JCR (fator de impacto "j") e o SCOPUS (índice "h") como bases preferenciais de indexação para os periódicos nos estratos superiores (A1, A2 e B1). Adicionalmente, as bases MEDLINE e SciELO foram consideradas no estrato B1, devido à importância atribuída à veiculação da produção científica, associada à visibilidade internacional, por parte da grande área da saúde, além do fato de compreenderem bases de dados com critérios que privilegiam a qualidade do conteúdo e a gestão editorial, entre outras variáveis. Para os estratos intermediários, adotou-se as bases LILACS, CINAHL, EMBASE, ERIC, SPORT DISCUS e LATINDEX, devido à importância para o desenvolvimento específico da Área 21, bem como por constituírem bases de dados com critérios mais flexíveis, mas com comitê de seleção. As bases de dados sem critérios explícitos, mas de instituições reconhecidas na área, compreendem os estratos inferiores, como por exemplo: PHYSICAL EDUCATION INDEX, CAB ABSTRACT, PERIÓDICA, OPEN JOURNAL SYSTEMS, SCIENTIFIC CAMBRIDGE ABSTRACTS. (CAPES, 2010, p. 2$3)$.
} 
incidências da decadência ideológica na pós-graduação brasileira, expressão essa que tem se legitimado tanto pelo irracionalismo como pela miséria da razão. Nossa tentativa no decorrer do trabalho foi apresentar como essas categorias se tornaram expressivas e como tem impactado o contexto da área, com especificidade para a miséria da razão, se tornando evidente a partir da tecnocracia, burocratização dentro dos programas de pós-graduação e produtivismo para atendimento das demandas de avaliação da CAPES.

\section{2 - A educação física no quadro da pós-graduação brasileira}

A trajetória histórica ${ }^{121}$ da EF evidencia os anos 90 como cruciais para as mudanças pelas as quais ela passaria:

[...] entendemos que as circunstâncias históricas dos anos 90 (as determinações da realidade) foram extremamente avessas ao projeto de "intenção de ruptura" da Educação Física com seu passado conservador. Tal projeto, inaugurado nos anos 80, fortalecido até meados dos anos 90 , começa a se defrontar com um contexto (da pósmodernidade) extremamente conservador (em certo sentido, inclusive, reacionário) e absolutamente avesso ao marxismo - que tanto inspirou o projeto de "intenção de ruptura". O diagnóstico de que se trata de uma conjuntura avessa ao marxismo não significa o "fim de Marx", mas tão somente, a constatação de que a realidade não tem tendido para a teoria. (HÚNGARO, 2010, p. 142; Grifos do autor).

Antes mesmo da solidificação de um movimento renovador com discussões críticas de contraposição ao caráter instrumental de submissão à ordem capitalista, suas referências foram questionadas e/ou criticadas. Foi assentada, então, uma crise de paradigmas disseminada pelo chamado movimento pós-moderno, expressão da decadência ideológica burguesa. A burguesia na processualidade histórica assumiu definitivamente um papel negligente frente a um projeto emancipatório do ser humano com a ruptura dos ideais iluministas e uma postura contrarrevolucionária aos interesses universais. Seu trunfo é a disseminação da essência humana de um indivíduo burguês.

Em nível histórico-universal, a experiência de 1848 demonstrou os limites reais do projeto sócio-político conduzido pela burguesia - a liberdade deve restringir- se à liberdade de concorrer no mercado, a igualdade esgota-se na formalidade jurídica e a fraternidade se resolve na retórica e no moralismo. O projeto de emancipação humana, nestes limites, não desborda o terreno da emancipação política, tal como Marx mesmo o vislumbrou em 1844 (Marx, 1969). A partir desse marco, o protagonismo burguês centra-se na conservação da ordem (para a qual concorrem, necessariamente, programas reformistas, tornados especialmente claros depois de 1848) que se veio instaurando sobre as ruínas do Antigo Regime. A burguesia, enquanto classe, perde o interesse e a capacidade de fazer avançar a socialidade para

\footnotetext{
${ }^{121}$ Para maiores esclarecimentos, ver Castellani Filho (1991), Darido (2003), Soares (2004), entre outros.
} 
além dos limites da lógica de acumulação e valorização do capital, em razão da qual se operou a emancipação política e se estabeleceu originalmente a figura do cidadão. $A$ dimensão essencial da emancipação humana só terá sentido para um outro sujeito histórico, cuja emersão primeira verifica-se em 1848: o proletariado. (NETTO, 1998, pp. 6-7; Grifos do autor).

Com a decadência do pensamento burguês e sua consolidação no poder, a preocupação dos intelectuais não é mais mostrar a verdade, e sim justificar o existente. A decadência ideológica consiste nas contradições internas da sociedade burguesa. Logo, o problema central no obscurantismo das reais debilidades da sociedade. Há uma deturpação delas pela (des)consideração da aparência em detrimento da realidade tornando as deformações humanas "normais".

A decadência ideológica avança expressivamente sobre a ciência esquivando-se da análise concreta do real por meio da coincidência entre o aparente e o verdadeiro. A ideia de progresso se torna contradição neste contexto decadente sendo um problema do desenvolvimento da sociedade de classes, pois desemboca na unilateralização do conhecimento e na impossibilidade do reconhecimento do sujeito enquanto histórico. Por outro lado, a Teoria Social de Marx está na direção oposta desse processo social quando da compreensão da sociedade civil burguesa ao se preocupar " [...] com a totalidade da vida social, interessada em descobrir a verdade do mundo [...]" (LARA, 2013, p. 92), revelando a constituição do ser social e apresentando a totalidade do mundo - objeto da ontologia do indivíduo humano. Portanto, a sociedade capitalista percebe a importância da criação de teorias que expliquem a acumulação capitalista, naturalizando à exploração das forças de trabalho e condicionando a realidade ao efêmero.

Coutinho (2010) traz que a burguesia trabalha de maneiras distintas para a manutenção do status quo, com variações conforme sua estabilidade no poder pela ocupação de diferentes esferas fetichizadas da realidade. Com estabilidade, a burguesia atua com a instrumentalização da razão, ou seja, reduz a simples regras formais o racionalismo e tem-se a práxis manipulatória. Em tempos instáveis, as crises, o pensamento burguês age com a ideia do irracionalismo, com a destruição da razão. Surge assim à oposição entre o anticapitalismo romântico e a apologia direta do progresso capitalista (COUTINHO, 2010, p. 45). O primeiro enquanto uma ameaça à subjetividade dos indivíduos, isto pela radical socialização do trabalho. Já a apologética burguesa negava as contradições da objetividade econômica alegando que havia nessas condições equilíbrio e progresso linear. Mais tarde essa tendência passa a estabelecer "limites" à compreensão racional da realidade, recaindo no 
agnosticismo e o formalismo apropriando-se do positivismo. Para Coutinho (2010, p. 45), a decadência ideológica trata-se de uma antinomia que não é superada.

Neste sentido, a decadência está orientada para o esvaziamento geral do real. A dissimulação do "crítico" e do "revolucionário" é ainda mais perigosa em virtude da extensão de sua atuação para além da política e da economia. As atenções se voltam para as respostas relativas ao processo capitalista. Tanto as contradições do progresso burguês quanto da divisão social do trabalho, por aumentarem as condições alienantes dos sujeitos, estão relacionadas aos problemas indicados por Lukács (2010). A burguesia do pós 1848 simultaneamente necessitava de apoiar-se no poder e de organização para que o "progresso" se efetivasse, o que está diretamente relacionado com a divisão social do trabalho.

Com o modo de produção capitalista torna-se fundamental a divisão social do trabalho, isso para manutenção dessa 'nova burguesia' no poder. Conforme Lukács, a primeira divisão acontece entre cidade e campo. Segundo Marx (apud Lukács, 2010, p. 62), é [...] a expressão mais brutal da subsunção do indivíduo à divisão do trabalho, a uma atividade prefixada e imposta: uma subsunção que faz do primeiro um mesquinho animal urbano e do outro um mesquinho animal rural [...]. A segunda divisão é entre trabalho físico e trabalho espiritual. Ambas as cisões ocasionam a transformação da quantidade em qualidade.

Estas divisões influem incisivamente na decadência porque geram especializações do conhecimento que comprometem a compreensão da totalidade. Desta maneira, Lukács (2010) se coloca a favor de um conhecimento articulado, vinculado com a totalidade, na tentativa de formação omnilateral, entendendo que a categoria da totalidade não é saber tudo sobre todas as coisas, mas um “complexo de complexos" (HÚNGARO, 2008).

Percebe-se que existe uma corrida para cumprimento das determinações - expansão, produção e internacionalização - da CAPES em relação à pós-graduação brasileira, nesse sentido as expressões tecnocráticas, burocráticas e produtivistas tem de certa forma gerado tensionamentos e questionamentos no meio acadêmico em relação a tais determinações, a lógica expansionista, adotada desde o I PNPG tem se fortificado a cada ano, para que tal expansão ocorra é fundamental que a produção acadêmica seja condizente com as imposições do Sistema Nacional de Avaliação, sendo atendidas as imposições consequentemente o padrão internacional será alcançado.

Porém, a realidade dos cursos de pós-graduação tem sofrido com consequências no que diz respeito ao atendimento de tais demandas. No contexto da EF não tem sido diferente, iniciaremos nossa análise pelo aumento dos cursos de pós-graduação, o período considerado 
para análise corresponde de 2001 a 2012, os documentos utilizados para o levantamento dos dados foram os documentos da área 21, 2001/2003; 2004/2006; 2007/2009; 2010/2012 e os relatórios de avaliação dos triênios 2007/2009 e 2010/2012. Em relação aos documentos foram considerados os dados referentes à Educação Física, sendo desconsideradas as demais áreas componentes da área 21. O aumento dos cursos de pós-graduação em Educação Física se deve as determinações da CAPES, citadas anteriormente, essas foram embasadas no VI PNPG, é possível identificarmos que as determinações acerca da pós-graduação se constituíram a partir da idéia de empreendimento, verdadeiramente com metas e processos estabelecidos, a serem cumpridos ${ }^{122}$.

O Sistema Nacional de Pós-Graduação (SNPG) é reconhecido pela comunidade científica como um dos empreendimentos de maior sucesso já realizados pela sociedade brasileira. O SNPG é responsável pela oferta dos cursos de pós-graduação nos níveis de mestrado e doutorado. (BRASIL, 2011, p. 155).

Portanto, a divisão capitalista do trabalho se dá na alteração das consciências deformando-as e limitando-as ao aparente, fragmentando teoria e prática, afetando diretamente a subjetividade e a sensibilidade dos sujeitos, impossibilitando-os que se reconheça na condição do outro, [...] cuja objetividade fatalista e desumanizada se contrapõe, ameaçadora e incompreendida, ao indivíduo (LUKÁCS, 2010, p.66). A partir desse contexto percebe-se que a lógica do sistema capitalista se instaura de maneira 'sutil' nas mais variadas instâncias.

Marx ao analisar a subordinação do homem à divisão do trabalho deixa bem claro as condições minimalistas de vida e o caráter animalesco dessa subordinação. Estas condições passam a ser reproduzidas porque os homens não se rebelam contra as imposições postas. No que se refere ao campo ideológico, apresenta-se um embate entre o racionalismo e o

122 Segundo Sánchez Gamboa (2015, p. 81) "As perspectivas da unidade de contrários incialmente foi apresentada por Marx em $O$ Capital, que as mercadorias são ao mesmo tempo quantidade e qualidade. "Como valores de uso as mercadorias, são antes de mais nada, qualidade diferente, como valores de troca só podem diferir na quantidade" (1998, p. 59). Um casaco enquanto valor de uso serve para aquecer e para mostrar status social, é pura qualidade, e como valor de troca pode ser igual a vários quilos de linho, medido em número de libras esterlinas, é pura quantidade. Segundo o mesmo Marx, citando A lógica de Hegel, o real se constitui de dimensões quantitativas e qualitativas e essas duas determinações se modificam mutuamente: "as modificações quantitativas, além de certo ponto, se transformam em modificações qualitativas” (ibidem, p. 355). Essas transformações das mudanças quantitativas e qualitativas são consideradas no marxismo uma das leis básicas do método dialético. A unidade quantidade/qualidade, segundo Sánchez Gamboa (2009), expressa-se na interrelação necessária entre as categorias elaboradas no processo do conhecimento. "Em relação às categorias qualidade/quantidade, as pesquisas com enfoque dialético, no que se refere às técnicas, geralmente utilizavam as historiográficas, tratando as dimensões quantitativas e qualitativas dentro do princípio do movimento. Essas categorias modificam-se, complementam-se e transformam-se uma na outra, e vice-versa, quando aplicadas a um mesmo fenômeno. (...) As duas dimensões se inter-relacionam como duas fases do real num movimento cumulativo e transformador, de tal maneira que não podemos concebê-las uma sem a outra, nem uma separada da outra (Sánchez Gamboa, 2009, p. 105)"”'. 
irracionalismo. Em Lukács (2010, p. 67), o primeiro [...] é uma direta capitulação, covarde e vergonhosa, diante das necessidades objetivas da sociedade capitalista. O irracionalismo é um protesto contra elas, mas igualmente impotente e vergonhoso, igualmente vazio e pobre de pensamento.

Para Marx, o ser humano é considerado a partir do todo, enquanto sensível. Ele se constitui pelo concreto e real. As falsas representações de si não correspondem à essência do indivíduo humano. [...] Os pressupostos de que partimos não são arbitrários, nem dogmas. São pressupostos reais de que não se pode fazer abstração a não ser na imaginação. [...] (MARX, 1999, p. 27). Marx se apoia em bases materialistas históricas, bases essas que dão fundamento aos embates no que se refere às concepções idealistas.

Não obstante, segundo Lukács (2010), no marxismo, a relação entre indivíduo e classe é sempre considerada a partir da complexa dialética da realidade. Portanto, os determinantes sociais muitas vezes impossibilitam a emancipação de classe pondo como evidentes “os limites da própria classe”. A CAPES acaba por reproduzir tal lógica, a lógica do capitalismo contemporâneo, com o aumento dos programas de pós-graduação, consequentemente as expressões da miséria da razão se complexificam e legitimação do sistema se expressa por aqueles que estão à frente do processo “[...] Desse modo, a "completa subordinação das necessidades humanas à reprodução do valor de troca - no interesse da autorrealização expansiva do capital - tem sido o traço mais notável do sistema de capital desde sua origem”. (ANTUNES, 2009, p. 23).

Sendo assim a acumulação flexível é uma "nova forma" do capitalismo que surge da "velha forma" do sistema, objetivando sempre o acúmulo de capital, segundo Húngaro (2012, p. 27) alguns elementos e relações invariantes são válidos para o modo de produção capitalista, estes delineados por Marx, 1) o capitalismo é orientado para o crescimento; 2) o crescimento em valores reais apoia-se na exploração do trabalho vivo na produção; 3) o capitalismo, é por necessidade, tecnológica e organizacionalmente dinâmico.

A flexibilização do trabalho, as mutações no processo tecnológico, a desregulamentação no processo produtivo foi mediado pelo Estado e regulado pelo capital, sendo assim a acumulação flexível e o toyotismo tomam forma deixando mais evidentes as características do capitalismo contemporâneo. Os professores do ensino superior expressaram sua compreensão acerca dos acontecimentos através de uma Carta no $14^{\circ}$ congresso do ANDES; 
A redução do Estado fortalece a iniciativa privada, lógica que pode ser percebida nas reformas sobre a Ordem Econômica ao se propor o fim da diferença entre empresas brasileiras e estrangeiras para evitar a restrição ao Capital estrangeiro, flexibilização do monopólio da exploração do petróleo e a concessão de serviços de telecomunicação as empresas privadas. A concessão de serviço publico as empresas privadas e outra forma de "flexibilização", e um mecanismo importante de transferência de recursos públicos para os setores empresariais privados, na melhor tradição de capitalização privada dos lucros e de socialização das perdas (Carta do $14^{\circ}$ Congresso Nacional do ANDES, 1995).

Nesse contexto a pós-graduação brasileira é direcionada para a formação técnica ${ }^{123} \mathrm{e}$ para o desenvolvimento de competências, de forma " [...] a incentivar a formação de quadros com um leque amplo de competências, capacitados para atuar nas complexas e múltiplas tarefas envolvidas na modernização estatal”. (INFOCAPES, 1995).

As diversas mudanças nos critérios e nas formas de avaliação da CAPES são expressões dessa lógica da acumulação flexível, pois a tentativa é de padronização internacional, atendendo as demandas comerciais do capitalismo. Sendo assim, segundo a CAPES o crescimento da área 21 se deu num processo de melhoria da qualidade da pósgraduação, qualidade direcionada para o atendimento de demandas internacionais. Na tabela a seguir percebe-se que a expansão dos cursos de pós-graduação em educação física aconteceu numericamente de maneira expressiva. Demandas essas que desembocam na lógica da acumulação flexível.

\begin{tabular}{|c|c|c|c|}
\hline \multicolumn{4}{|c|}{$\begin{array}{l}\text { TABELA } 1 \text { - TOTAL DE CURSOS DE PÓS-GRADUAÇÃO EM } \\
\text { EDUCAÇÃO FÍSICA AVALIADOS POR TRIÊNIO }{ }^{124}\end{array}$} \\
\hline TRIÊNIOS & $\begin{array}{c}\text { VALOR } \\
\text { ABSOLUTO }\end{array}$ & $\begin{array}{l}\text { VARIAÇÃO } \\
\text { ABSOLUTA }\end{array}$ & $\begin{array}{l}\text { VARIAÇÃO } \\
\text { RELATIVA }\end{array}$ \\
\hline $2001 / 2003$ & 13 & - & - \\
\hline $2004 / 2006$ & 17 & 4 & $30,76 \%$ \\
\hline $2007 / 2009$ & 20 & 3 & $17,64 \%$ \\
\hline $2010 / 2012$ & 27 & 7 & $35 \%$ \\
\hline
\end{tabular}

\footnotetext{
${ }^{123}$ Segundo Sánchez Gamboa (2010, p. 107) "Como desdobramento do reducionismo técnico e da falsa opção entre técnicas quantitativas ou qualitativas, surge o falso dualismo entre modelos quantitativos e qualitativos. [...] as técnicas não têm sentido em si mesmas. A técnica é a expressão prático-instrumental do método, e esse, por sua vez, expressa uma teoria de pesquisa em ação. E as teorias são maneiras diversas de ordenar o real, de articular diversos aspectos de um processo global e de explicitar uma visão de conjunto. Esses elementos são articulados nos paradigmas epistemológicos. Deduzimos daí a necessidade de remeter as opções da pesquisa às grandes tendências epistemológicas e não apenas considerar as alternativas técnicas".

${ }^{124}$ Valor absoluto: representa o número de cursos de pós-graduação em Educação Física criados em um determinado triênio. A variação absoluta representa a diferença de um triênio em relação ao outro imediatamente superior. A variação relativa demonstra o crescimento ou decrescimento percentual entre os triênios.
} 
Percebe-se que há uma variação de crescimento de um triênio em relação ao outro na quantidade de programas de pós-graduação da área, o triênio de 2004/2006 apresentou um aumento de 4 cursos de pós-graduação em relação ao triênio de 2001/2003; já no triênio de 2007/2009 houve um aumento de 3 cursos em relação ao triênio de 2004/2006 - percebe-se que em relação ao comparativo dos triênios anteriores houve um decréscimo no aumento, isso em função das mudanças nos critérios de avaliação. Já no que se refere ao triênio de 2010/2012 se comparado ao triênio 2007/2009 houve um aumento de 7 cursos, portanto, o maior quantitativo de cursos se comparado aos triênios anteriores, esse aumento é o reflexo real das políticas de expansão do VI PNPG ${ }^{125}$.

A educação física ${ }^{126}$ encontra-se localizada na grande área das ciências da saúde, especificamente na área 21, tal área também é composta pela fisioterapia, fonoaudiologia e terapia ocupacional, sendo assim conforme o documento do triênio 2010/2012 é perceptível à expansão na área 21 , no que diz respeito ao documento as menções no que se refere à qualidade também foram alcançadas, pois, alguns PPGEFs alcançaram o padrão de internacionalização, porém algumas adversidades têm sido enfrentadas.

O documento destaca, ainda, que a área apresenta uma produção diversificada (subáreas de Saúde e Humanas) e enfrenta dificuldades com os periódicos indexados internacionalmente no Qualis da área, pois são poucos e a maioria é internacional. Assim sendo, o próprio relatório sugere a constituição de uma política de qualificação dos periódicos nacionais, conforme as áreas específicas da Área 21 (Educação Física, Fisioterapia, Terapia Ocupacional). (SILVA, 2013, p. 119-120).

Ainda no que se refere ao aumento dos números de cursos de pós-graduação em educação física, torna-se evidente que anteriormente os cursos de mestrado se sobressaiam em relação aos cursos de mestrado/doutorado, porém ao analisarmos os documentos de área, Tabela 2, verificaremos que a partir do triênio 2007/2009 essa questão foi invertida.

\footnotetext{
${ }^{125}$ Segundo Kuenzer e Moraes (2005, p. 1342-1343) “A pós-graduação brasileira foi implantada com o objetivo de formar um professorado competente para atender com qualidade à expansão do ensino superior e preparar o caminho para o decorrente desenvolvimento da pesquisa científica. Vale registrar que a primeira denominação da CAPES foi a de "Campanha de Aperfeiçoamento de Pessoal para o Ensino Superior". No entanto, não obstante as boas intenções e os índices notáveis dos dias atuais, o país ainda não superou o desafio de formar um número suficiente de docentes titulados para este nível. Dos pouco mais de 254 mil professores do ensino superior no Brasil, apenas $21 \%$ têm doutorado e $35 \%$, mestrado. Ademais, os dados perdem muito de sua expressividade se comparados ao número de egressos por 100 mil habitantes de outros países: entre 1997 e 2003, a Alemanha atingiu o patamar de 30 doutores por 100 mil habitantes; em 2001, o Reino Unido alcançou 24, e os EUA 14 doutores por 100 mil habitantes. Em 2000, a Coréia do Sul registrou a marca de 13,6, e o Japão 12,1 doutores/100 mil habitantes. Em 2003, o Brasil formou 4,6 doutores/100 mil habitantes. Como se vê, ainda há um longo caminho a percorrer (CAPES, 2004, V PNPG, p. 37)".

126 “[...] A Educação Física constitui-se no lócus privilegiado de todo processo educativo, por abordar as situações basilares, onde se constitui e se desenvolve o humano, a partir das condições naturais e sociais imbricadas entre si. Condições básicas que potencializam a produção social da existência dos homens". (SÁNCHEZ GAMBOA, 2010, p. 36).
} 


\begin{tabular}{|c|c|c|c|c|}
\hline \multicolumn{5}{|c|}{ TABELA 2 TOTAL DE CURSOS DE PÓS-GRADUAÇÃO EM EDUCAÇÃO } \\
FÍSICA DE (M), (M/D) E (MP) AVALIADOS POR TRIÊNIO
\end{tabular}

Fonte: Documentos Trienais da Área 21 - CAPES.

\footnotetext{
* Consideradas as instituições com Mestrado Acadêmico

** Consideradas as instituições com Mestrado e Doutorado

*** Consideradas as instituições com Mestrado Profissional
}

Na Tabela 2 o valor absoluto expressa o total da quantidade de cursos de pósgraduação em Educação Física, o número de cursos de $\mathrm{M}$ avaliados expressam a quantidade de cursos de $\mathrm{M}$ dentro do valor absoluto, já no que se refere ao número de cursos de M/D avaliados, esses expressam a quantidade de cursos de M/D dentro do valor absoluto, por fim o número de cursos de MP expressa à quantidade de cursos de MP dentro do valor absoluto.

Ao compararmos o triênio de 2004/2006 com o triênio 2001/2003 percebemos que houve um acréscimo de 4 cursos de pós-graduação, correspondentes a uma variação relativa percentual de 30,76\% em relação ao período anterior, desses 4 cursos de pós-graduação os 4 foram acrescidos aos cursos de $\mathrm{M}$, sendo assim não houve aumento dos cursos de M/D em relação a esse período.

Ao compararmos o triênio de 2007/2009 com o triênio 2004/2006 percebemos que houve um acréscimo de 3 cursos de pós-graduação, correspondentes a uma variação relativa percentual de 17,64\% em relação ao período anterior, desses 3 cursos de pós-graduação, 1 foi acrescido aos cursos de $\mathrm{M}$ e 2 aos cursos de $\mathrm{M} / \mathrm{D}$, portanto, em relação ao período anterior torna-se perceptível a lógica inicial de expansão da CAPES, que se constituiu a partir do $\mathrm{V}$ PNPG - 2005/2010.

Por fim, ao compararmos o triênio de 2010/2012 com o triênio 2007/2009 percebemos que houve um acréscimo de 7 cursos de pós-graduação, correspondentes a uma variação relativa de $35 \%$ em relação ao período anterior, desses 7 cursos de pós-graduação, 1 foi acrescido aos cursos de M e 6 aos cursos de M/D, portanto, em relação aos períodos anteriores foi o maior aumento dos cursos de M/D em relação ao cursos de M, lógica essa que 
atendeu/atende as políticas de pós-graduação em relação a expansão, que se constituiu a partir do VI PNPG - 2011/2020.

Tal inversão se deve as novas políticas de expansão da pós-graduação, que citamos anteriormente, portanto, torna-se evidente que a pós-graduação, não só em educação física, foi se perdendo no meio de indexadores e indicadores do QUALIS, confundindo medir com avaliar. No que diz respeito ao MP, o primeiro na área foi aprovado em 2012, essa perspectiva de formação também é uma exigência do IV PNPG, isso na tentativa de minimizar lacunas de formação dos professores do ensino básico.

\begin{abstract}
A leitura dos documentos da CAPES, os investimentos nos indicadores de avaliação denotam sem subterfúgios quais são as prioridades políticas impostas aos programas de PG quanto à formação - formamos pesquisadores -, e à produção - proeminência do artigo como a produção. [...] Nos anos 1990, há um investimento no aperfeiçoamento do sistema nacional de avaliação. A partir desse período um dos temas que ensejaram os debates mais calorosos nas rodas acadêmicas refere-se aos critérios de avaliação. Ganha força a ideia de um sistema que avalie os programas de maneira uniforme, com um conceito de rigor que independe da área. Uma nota ou conceito dado a um programa numa área deve ser equivalente à mesma nota ou conceito dado a outro programa de área diversa. [...] Nos últimos anos o que mais se discute não são tanto os critérios, mas os indicadores utilizados para atribuir notas aos programas, cujo melhor exemplo é o QUALIS. Mas e a avaliação? Ela comumente é confundida com os indicadores num equívoco que merece ser tratado como elementar, pois medir é tratado como sinônimo de avaliar. E a PG? Ninguém sabe, ela se perdeu nos meandros dos indexadores, dos indicadores, dos QUALIS (MANOEL, 2009, p. 88-89).
\end{abstract}

Nesse sentido já percebemos certa preocupação crítica com o atual contexto da pósgraduação brasileira, não só ao que se refere à educação física ${ }^{127}$, mais sim a PG como um

\footnotetext{
${ }^{127}$ Segundo Sánchez Gamboa (2010, p. 35-36) "A definição da Educação Física como uma das ciências da prática e da ação não se fundamenta apenas por ter como ponto de partida e de chegada a motricidade, o movimento humano, a corporeidade, ou a cultura corporal, mas também pela natureza da própria Educação Física. Se partirmos do termo básico da Educação, podemos argumentar com Saviani, quando define a natureza da educação como trabalho não material, na medida em que o produto não se separa do ato de produzir e quando "o ato de produzir e o ato de consumo se imbricam" (SAVIANI, 1991, p. 20) e, se levarmos em conta que a educação como um fenômeno humano passa pela compreensão da natureza humana, a especificidade da educação, de todo e qualquer tipo de educação está vinculada a esse tipo de trabalho não material que produz no homem a sua natureza humana, a partir da natureza biofísica, que constitui algo como uma segunda natureza. Trabalho necessário à constituição humana do homem, natureza humana que não está pronta na natureza biofísica. "Portanto, o que não é garantido pela natureza tem que ser produzido historicamente pelo homem; e aí se incluem os próprios homens. Podemos, pois dizer que a natureza humana não é dada ao homem, mas é por ele produzida sobre a base da natureza biofísica. Consequentemente, o trabalho educativo é o ato de produzir, direta e intencionalmente, em cada indivíduo singular, a humanidade que é produzida histórica e coletivamente pelo conjunto dos homens (SAVIANI, 1991, p. 21)". A natureza da Educação Física, como um tipo especifico da educação, é um trabalho não material cujo produto se dá no mesmo processo de atividade, do exercício, do fazer, da realização da motricidade, nos atos de correr, jogar, nadar, dançar, competir, brincar etc. atividades e processos que desenvolvendo a natureza biofísica do homem, também desenvolvem fundamentalmente sua natureza humana. Atos e processos complexos em que é impossível separar as "duas naturezas" porque se imbricam mutuamente, constituindo uma unidade concreta na ação humana direta e intencional dos homens (trabalho) que transforma a natureza biofísica em natureza humana".
} 
todo articulado, pois, a cada dia mais a miséria da razão tem se tornada evidenciada e tem ganhado força, ofuscando a realidade, “[...] Com "miséria da razão”, queremos significar o radical empobrecimento agnóstico das categorias racionais, reduzidas às simples regras formais intelectivas que operam na práxis manipulatória” (COUTINHO, 2010, p. 18).

Outra questão perceptível quanto à quantidade de cursos de pós-graduação em educação física se da pelo desequilíbrio referente à distribuição geográfica desses cursos, na Tabela 3 perceberemos que as regiões sul e sudeste se tornaram pioneiras em pesquisa e pósgraduação.

\begin{tabular}{|c|c|c|c|c|c|c|}
\hline \multirow[t]{2}{*}{ TRIÊNIOS } & \multirow{2}{*}{$\begin{array}{c}\text { VALOR } \\
\text { ABSOLUTO }\end{array}$} & \multicolumn{5}{|c|}{ REGIÕES } \\
\hline & & NORTE & SUL & $\mathrm{NE}^{*}$ & SE** & $\mathrm{CO} * * *$ \\
\hline $2001 / 2003$ & 13 & - & $\begin{array}{c}5 \\
(38,46 \%) \\
\end{array}$ & - & $\begin{array}{c}7 \\
(53,84 \%) \\
\end{array}$ & $\begin{array}{c}1 \\
(7,69 \%)\end{array}$ \\
\hline $2004 / 2006$ & 17 & - & $\begin{array}{c}5 \\
(29,41 \%)\end{array}$ & - & $\begin{array}{c}10 \\
(58,82 \%)\end{array}$ & $\begin{array}{c}2 \\
(11,76 \%)\end{array}$ \\
\hline $2007 / 2009$ & 20 & - & $\begin{array}{c}7 \\
(35 \%)\end{array}$ & $\begin{array}{c}1 \\
(5 \%)\end{array}$ & $\begin{array}{c}10 \\
(50 \%)\end{array}$ & $\begin{array}{c}2 \\
(10 \%)\end{array}$ \\
\hline $2010 / 2012$ & 27 & - & $\begin{array}{c}8 \\
(29,62 \%) \\
\end{array}$ & $\begin{array}{c}3 \\
(11,11 \%)\end{array}$ & $\begin{array}{c}13 \\
(48,14 \%)\end{array}$ & $\begin{array}{c}3 \\
(11,11 \%) \\
\end{array}$ \\
\hline
\end{tabular}

Fonte: Documentos Trienais da Área 21 - CAPES.

\footnotetext{
* Nordeste

** Sudeste

$* * *$ Centro-oeste
}

Na Tabela 3 o valor absoluto expressa o total da quantidade de cursos de pósgraduação em EF, as regiões expressam a quantidade de cursos de pós-graduação em EF por região. Ao compararmos o triênio de 2004/2006 com o triênio 2001/2003 percebemos que houve um acréscimo de 4 cursos de pós-graduação, correspondentes a uma variação relativa percentual de 30,76\% em relação ao período anterior, desses 4 cursos de pós-graduação os 4 foram acrescidos aos cursos de $\mathrm{M}$, sendo 3 acrescidos na região sudeste e 1 na região centrooeste.

Ao compararmos o triênio de 2007/2009 com o triênio 2004/2006 percebemos que houve um acréscimo de 3 cursos de pós-graduação, correspondentes a uma variação relativa percentual de 17,64\% em relação ao período anterior, desses 3 cursos de pós-graduação, 1 foi acrescido aos cursos de $\mathrm{M}$ da região norte e 2 aos cursos de $\mathrm{M} / \mathrm{D}$ da região sul.

Por fim, ao compararmos o triênio de 2010/2012 com o triênio 2007/2009 percebemos que houve um acréscimo de 7 cursos de pós-graduação, correspondentes a uma 
variação relativa de $35 \%$ em relação ao período anterior, desses 7 cursos de pós-graduação, 1 foi acrescido aos cursos de $M$ da região centro-oeste e 6 aos cursos de M/D, desses 6 cursos de M/D, 1 foi acrescido a região sul, 2 foram acrescidos a região nordeste, 3 foram acrescidos a região sudeste.

Mesmo com a expansão dos cursos de pós-graduação nas regiões Nordeste e CentroOeste, há uma lacuna na região Norte. Conforme o VI PNPG essas assimetrias regionais foram repensadas por ações estimuladas pela CAPES a partir de 2005 e " [...] visaram atender Demandas identificadas pela comunidade, sociedade científicas, coordenadores de áreas, pela própria diretoria, por demandas geradas por ministérios, estados e suas FAPs, e ainda, em menor escala, pelo setor empresarial” (BRASIL, 2011, p. 284). Tais ações são: Acelera Amazônia, DINTER Novas Fronteiras, PRODOUTORAL e PROCAD Novas Fronteiras.

Esses aumentos dos cursos impactaram o corpo docente e consequentemente sua produção intelectual, isso devido a consecutivas alterações da DAV. Essa questão é primordial, pois, essa é a expressão da miséria da razão no contexto da pós-graduação em EF. No decorrer do trabalho compreendemos que as exigências para produção intelectual desembocam no produtivismo, portanto incidências da decadência ideológica se tornaram constância no meio.

A partir desse contexto nos deparamos com inúmeras questões, no que se refere a tecnocracia percebemos que há uma constante busca por mensuração do setor público, no que diz respeito a burocratização nos deparamos com a 'cultura da auditoria ${ }^{128}$, para reforçar a logica da mensuração, cada vez mais são necessários preenchimento de relatórios, atualização do lattes, além das incontáveis prazos e períodos a serem cumpridos, por fim o produtivismo se expressa a partir da pontuação mínima que o docente tem que cumprir para permanecer credenciado no programa. Quanto à mensuração da qualidade da produção Kuenzer e Moraes (2005, p. 1347) afirmam que

[...] a qualidade da produção - o verdadeiramente relevante - dificilmente pode ser mensurada, porquanto ainda não se descobriu uma formula razoável e rápida para

\footnotetext{
128 "Sobre esse processo, em segunda versão de um texto publicado originalmente na Inglaterra, Shore (2009) refere-se ao método que classifica professores, pesquisadores e Instituições de Ensino Superior, via práticas de cálculo que incluem indicadores de desempenho que são cada vez mais utilizados para medir e aperfeiçoar organizações do setor público, na busca de melhorar a produtividade dos trabalhadores em diversas profissões. Essa forma de gestão e avaliação se constituiria numa "cultura da auditoria" (Shore, 2009, p. 27), uma expressão que designa o uso de técnicas e princípios da auditoria financeira, adotadas em contextos distantes desse universo. Como uma verdadeira "cultura", a auditoria induziria as pessoas a se medirem a si próprias mediante indicadores de desempenho advindos de níveis externos, reduzindo tudo a contagens matemáticas que possibilitariam a comensurabilidade entre todas as áreas e entre os sujeitos envolvidos”. (STIGGER; SILVEIRA; MYSKIW, 2015, p. 21).
} 
avaliar a qualidade em termo do impacto social e científico dos produtos na qualidade de vida, na democratização social e econômica, na preservação do ambiente e assim por diante.

Sendo assim, o novo paradigma de avaliação ${ }^{129}$ dos programas de pós-graduação, ao valorizar enfaticamente a produção científica, rompeu com as propostas de vigentes até o III PNPG, pois alterou significativamente a centralidade da pós-graduação da docência somente para a pesquisa. Segundo as autoras, embora essas determinações contribuam para a expansão cientifica, na contramão contribuiu para um surto produtivista.

A quantidade institui-se em meta. Deste modo, formas legítimas de produção, como co-autorias e organizações de coletâneas - em inúmeros casos produtos de sólidas pesquisas integradas -, banalizaram-se no âmbito de algumas áreas de conhecimento, entre elas a Educação. No caso das coletâneas, nota-se, muitas vezes, tendência a um ensaísmo que longe está do necessário avanço na construção de uma produção consolidada e orgânica acerca dos objetos de investigação. No das coautorias, em particular a de docentes com discentes e em trabalhos completos em eventos, alguns exageros "não permitem que se possa aferir o que é resultado de investigação específica de docente, de discentes ou de efetiva co-autoria" (CAPES, Documento da área de Educação). Dessa forma, o incentivo para que orientadores e orientandos publiquem juntos, a partir de uma crescente participação do corpo discente nos projetos de pesquisa dos orientadores desvirtua-se, reduzindo- se a um incansável roteiro de sucessivas apresentações em eventos, no exterior e no país. (KUENZER; MORAES, 2005, p. 1348).

Umas das necessidades nos últimos anos são de indicações dos melhores professores dos programas, melhores esses que são definidos pela quantidade de publicações que conseguiu ao longo dos triênios, publicações essas que se tornam ainda mais 'importantes' se forem 'internacionais'. Adiante observaremos a quantidade dos docentes por triênio 2001/2003, 2004/2006 e as avaliações conceituais dos triênios 2007/2009, 2010/2012.

\footnotetext{
129 Segundo Kuenzer e Moraes (2005, p. 1347) “O novo modelo de avaliação, uma vez que valoriza prioritariamente a produção científica e, portanto, a pesquisa, provocará a inversão proposta anos antes pelo III PNPG: o deslocamento da centralidade na docência para a centralidade na pesquisa. Em que pesem as justificadas críticas à sistemática de avaliação, pode-se identificar uma vez mais o papel indutor do Estado no redirecionamento da pós-graduação. A partir do novo instrumento e, portanto, do enfoque central na pesquisa, evidenciaram-se alguns indicadores desta nova concepção. Introduziu-se a idéia de Programa, e não mais de cursos de mestrado e doutorado avaliados isoladamente; atenção especial voltou-se às linhas de pesquisa e à sua organicidade com as disciplinas, projetos e produtos de pesquisa, teses e dissertações; as linhas, e não mais as preferências docentes, passaram a definir: a) os percursos curriculares, organizados a partir da pesquisa, e não mais das disciplinas; b) os seminários de pesquisa e de dissertação; c) a definição dos orientadores já no início dos cursos; d) os objetos de investigação como determinantes do percurso curricular, agora flexibilizado".
} 


\begin{tabular}{|c|c|}
\hline \multicolumn{2}{|c|}{ TABELA 4 - TOTAL DE PROFESSORES } \\
CREDENCIADOS NA PÓS-GRADUAÇÃO EM \\
EDUCAÇÃO FÍSICA POR TRIÊNIO
\end{tabular}

Fonte: Documentos Trienais da Área 21 - CAPES.

130 Desde o Triênio 2007/2009 as avaliações se tornaram conceituais, nesse sentido não nos foi possível identificar os valores absolutos acerca de alguns dados, portanto, consideramos as avaliações conceituais. A avaliação conceitual de um dos critérios de avaliação, CORPO DOCENTE, no triênio descrito foi a seguinte:

Corpo Docente (15\%) (CAPES, 2010a, p. 6-7-8)

Perfil do corpo docente, consideradas titulação, diversificação na origem de formação, aprimoramento e experiência, e sua compatibilidade e adequação à Proposta do Programa (10\%)

$\mathrm{Na}$ avaliação dos 36 programas acadêmicos, a seguinte distribuição dos conceitos foi obtida neste item: $\mathbf{M B}=18$ $(50,0 \%), \mathbf{B}=13(36,1 \%)$ e $\mathbf{R}=5(3,9 \%)$.

Adequação e dedicação dos docentes permanentes em relação às atividades de pesquisa e de formação do Programa (25\%)

$\mathrm{Na}$ avaliação dos 36 programas acadêmicos, a seguinte distribuição dos conceitos foi obtida neste item: $\mathbf{M B}=21$ $(58,3 \%), \mathbf{B}=13(36,1 \%)$ e $\mathbf{R}=2(5,6 \%)$.

Distribuição das atividades de pesquisa e de formação entre os docentes do Programa (25\%)

$\mathrm{Na}$ avaliação dos 36 programas acadêmicos, a seguinte distribuição dos conceitos foi obtida neste item: $\mathbf{M B}=26$ $(72,2 \%), \mathbf{B}=8(22,2 \%)$ e $\mathbf{R}=2(5,6 \%)$.

Contribuição dos docentes para atividades de ensino elou de pesquisa na graduação, com atenção tanto à repercussão que este item pode ter na formação de futuros ingressantes na PG, quanto (conforme a área) na formação de profissionais mais capacitados no plano da graduação (15\%)

$\mathrm{Na}$ avaliação dos 36 programas acadêmicos, a seguinte distribuição dos conceitos foi obtida neste item: $\mathbf{M B}=12$ $(33,3 \%), \mathbf{B}=9(25,0 \%), \mathbf{R}=12(33,3 \%)$ e $\mathbf{F}=3(8,3 \%)$.

Proporção do corpo docente com importante captação de recursos para pesquisa (Agências de Fomento, Bolsa de Produtividade, Financiamentos Nacionais e Internacionais, Convênios...) (25\%)

$\mathrm{Na}$ avaliação dos 36 programas acadêmicos, a seguinte distribuição dos conceitos foi obtida neste item: $\mathbf{M B}=15$ $(41,7 \%), \mathbf{B}=10(27,8 \%), \mathbf{R}=4(11,1 \%)$ e $\mathbf{F}=7(19,4 \%)$.

${ }^{131}$ Avalição conceitual do critério, CORPO DOCENTE, do triênio 2010/2012:

CORPO DOCENTE (20\%) (CAPES, 2013a, p. 32-33-34-35-36-37).

A área 21 buscou identificar as áreas de atuação acadêmica dos docentes permanentes em relação às áreas de concentração, linhas e projetos de pesquisa do corpo docente permanente e aplicou critérios subjetivos para identificar se os docentes têm pesquisado e publicado em temáticas relativas ao escopo do programa, independente de sua formação graduada ou pós-graduada. Nesse sentido, uma pequena fração do corpo docente de alguns programas tem apresentado baixa aderência ao escopo do programa, o que tem levado a uma baixa identidade na formação, diversidade e experiência do corpo docente em relação aos objetivos do programa. O nível de experiência do corpo docente, inclusive sua projeção nacional e internacional tem sido quantificado pela percepção das ações dos programas quanto a participação em sociedades nacionais/internacionais, palestras em eventos nacionais/internacionais. O item de estágios pós-doutorais havia sido proposto para a análise da excelência do corpo docente, porém tal informação nem sempre foi provida pelos coordenadores no coleta, dificultando a identificação de quantos e quais docentes haviam desenvolvido tais atividades. O número de docentes permanentes foi incrementado em relação ao triênio anterior, passando o número mínimo de docentes permanentes a 12 para uma avaliação "Boa". Os programas que estiveram abaixo desses indicadores não foram impedidos de continuarem suas atividades, porém receberam conceitos mais baixos. Encoraja-se que todos os programas da área busquem ampliar seus quadros docentes permanentes ao mínimo indicado. A estabilidade do corpo docente foi avaliada a fim de identificar a variação nos status de colaborador e permanente, sendo observadas variações pequenas (>80\% se mantiveram estáveis) e em casos esporádicos algumas pequenas variações [...]. 
O aumento no número de docentes impactou diretamente no aumento da produção intelectual, pois se não há produção não há possibilidade de se manter na pós-graduação. Segundo Stigger, Silveira, Myskiw (2015, p. 24) afirmam que mesmo com o aumento no número de docentes a quantidade de produção de artigos ainda é maior que o número de docentes. O gráfico a seguir expressa essa condição por ano de 1999 a 2012.

Não é novidade que, na últimas duas décadas, na ânsia de definir os "bons" pesquisadores/programas, de demarcar os problemas científicos e de selecionar os "melhores" investimentos, a quantidade de publicações passa a ocupar lugar de destaque como "indicador". Isso se refletiu claramente no cotidiano acadêmico, como evidencia o gráfico a seguir, por nós produzido a partir dos currículos Lattes de todos os pesquisadores de um dos programas de Pós-Graduação em Educação Física do Brasil [...] (STIGGER; SILVEIRA; MYNSKIW, 2015, p. 23).

\section{GRÁFICO 1 - NÚMERO DE DOCENTES E DE ARTIGOS PUBLICADOS POR ANO}

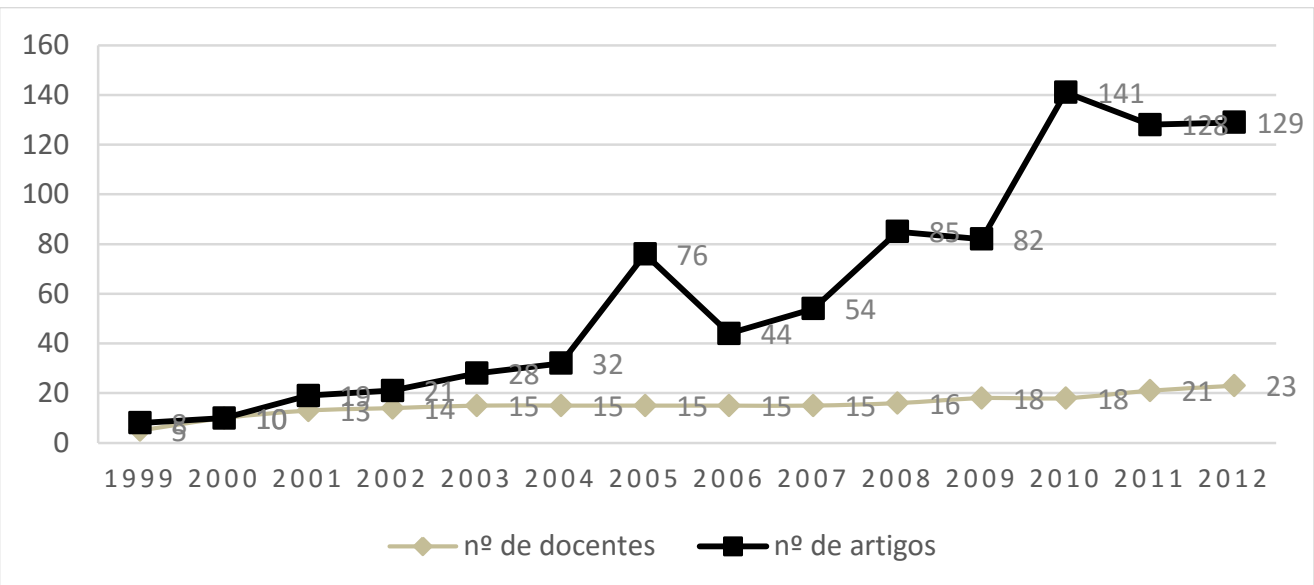

FONTE: STIGGER, SILVEIRA, MYSKIW (2015, p. 24).

O gráfico acima representa a quantidade de docentes e de artigos produzidos por docente, do ano de 1099 a 2012. Essa pesquisa escolheu aleatoriamente um curso de pósgraduação avaliado pela capes e considerou os currículos lattes dos professores do curso $^{132}$.

Como é possível perceber, a quantidade da produção de artigos vem crescendo, numa proporção maior que o aumento do número de docentes vinculados ao Programa. Enquanto que no ano 2000 os docentes publicavam 1,4 artigo em média, em 2012 a média cresceu para 5,6 artigos por pesquisador. Vale destacar que, em 2010, essa média chegou a alcançar 7,8 artigos por docente. (Ibidem).

Por mais que essa pesquisa seja de somente um Programa de EF, torna-se evidente os impactos que o produtivismo tem causado no meio acadêmico, não somente no que diz

132 Consideramos a pesquisa dos autores, Stigger; Silveira; Myskiw; por compreender que ao apresentar a realidade de algum dos cursos de Educação Física avaliado pela CAPES é fundamental, isso para que compreendamos como o impacto da miséria da razão tem se dado na realidade dos cursos. 
respeito a ajustes ou desajustes para se manterem no sistema, mais os impactos referentes a saúde tanto dos docentes quanto dos discentes também tem se mostrado fragilizada. Segundo Tuleski (2012, p. 1)

\begin{abstract}
Por outro lado, pesquisas apontam um crescente adoecimento físico dos docentes pesquisadores, como, por exemplo, a pesquisa de Santana (2011). Nela o autor evidencia de modo contundente a correlação entre o aumento de produção científica e o número médio anual de orientandos por pesquisador, com maiores ocorrências médicas relacionadas a intervenções cardíacas. Deste modo, além de estas exigências numéricas tornarem-se um problema de saúde física, esta lógica produtivista vem desencadeando uma competição desenfreada e uma "corrupção da personalidade humana", como atesta Vigotski (1930/2004), em que os valores se colocam de modo invertido na consciência dos pesquisadores, sob a pressão ideológica que Schlendlindwein (2009) denomina de "sistema de recompensa científica".
\end{abstract}

Quando a autora se refere a 'corrupção da personalidade humana' diz respeito às artimanhas das quais se tem utilizado para se manter no contexto da pós-graduação, a pressão institucional por publicação além de afetar o sentido de fazer ciência compromete o futuro da ciência brasileira. Na EF essas mudanças também têm impactado, uma das questões em voga na área é a hegemonia de publicações por parte da área biodinâmica. Voltando na pesquisa de Stigger, Silveira e Myskiw, um dado nos chamou atenção, a diferença no número de autores por artigo, o mesmo programa utilizado para o levantamento da quantidade de artigos por docente, foi utilizado para o comparativo do número de autores por artigo na área biodinâmica e sociocultural.

\title{
GRÁFICO 2 - QUANTIDADE DE AUTORES POR ARTIGOS NA LINHA DE PESQUISA DA ÁREA BIODINÂMICA
}

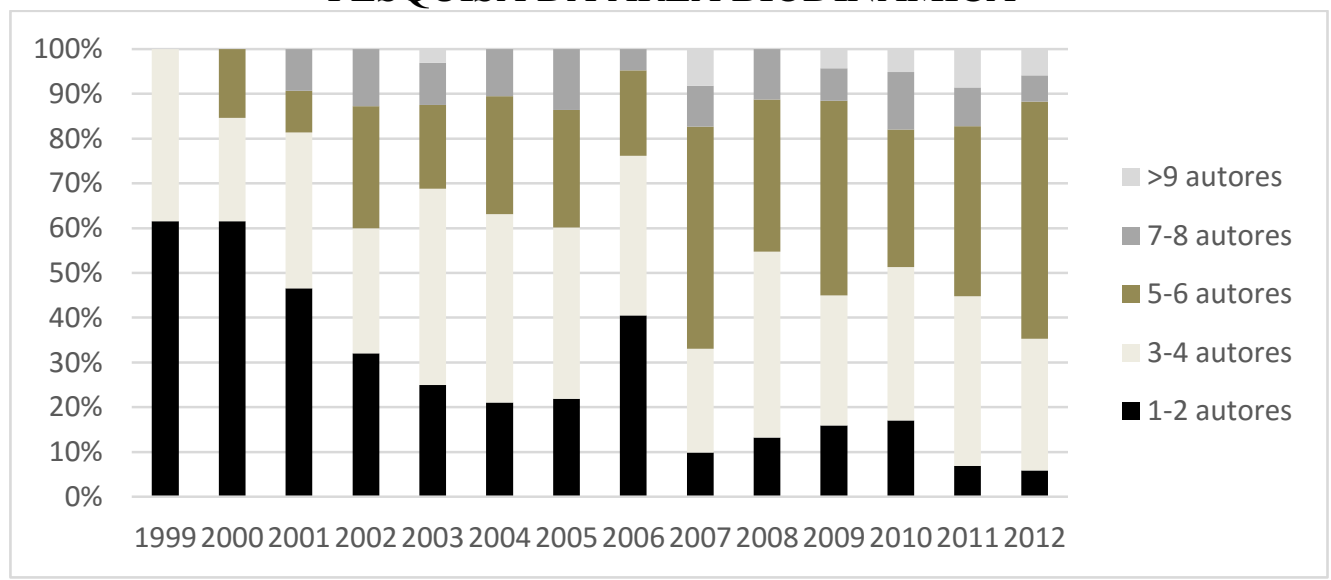

FONTE: STIGGER, SILVEIRA, MYSKIW (2015, p. 26).

O gráfico acima representa a quantidade de autores por artigo que compuseram as pesquisas biodinâmicas dos anos de 1999 a 2012. Percebe-se que foi significativo o aumento 
no número de autores por artigo com o passar dos anos, a realidade dos programas perpassa por colaboradores para submissão dos artigos, torna-se evidente que se compararmos o ano de 2012 com o ano de 1999, em relação aos artigos com 1 - 2 autores, torna-se notório que essa forma de produção foi praticamente desconsiderada, enquanto que a produção com 3 - 4/5 - 6 autores, "[...] Neste gráfico chama a atenção que mais de 70\% dos artigos publicados nessa linha de pesquisa têm entre cinco ou mais autores no ano de 2012 [...]" (STIGGER; SILVEIRA; MYSKIW, 2015, p. 26).

Na nossa pesquisa consideramos os documentos de área da capes, os triênios de 2001 a 2012, sendo assim, se comparamos a produção do ano de 2012 em relação ao ano de 2012, perceberemos que em 2001 a produção de artigos com o número de 1-2 autores ainda é bastante expressivo em relação a 2012, quase 50\%, já no que se refere a produção de artigos com mais de 5 autores é bem menor se compararmos, tais mudanças se devem as determinações das políticas da CAPES, no relatório do triênio de 2010/2012 encontramos algumas considerações que se encontram com as análises,

\begin{abstract}
A área adotou uma postura relevante no que se refere a produção intelectual da área, especialmente valorizando itens de produção nos estratos mais elevados, o que permitiu apontar para a necessidade de uma maior qualificação dos produtos em detrimento de aspectos apenas quantitativos. Assim, dois novos indicadores foram inseridos a fim de qualificar os volumes de produção dos programas e sua respectiva distribuição. A área demonstrou um aumento importante na quantidade de produtos, sendo que no presente triênio foram encontrados 7334 artigos [...]. (CAPES, 2013, p. 40).
\end{abstract}

A 'altura do sarrafo' tem se acirrado, e os documentos caminhado na contramão da minimização de tais contradições, mais sim reproduzindo com ainda mais veemência e imposições para edificação do sistema.

[...] Assim sendo, não se questiona que um corpo docente qualificado, responsável pela formação de professores/pesquisadores, tem o compromisso de transmitir e, também, de produzir conhecimento relevante que seja capaz de transformar problemas em soluções. Mais do que a negação da necessidade de considerar a produção cientifica na avaliação da Pós-Graduação, a insatisfação parece residir na forma como ela é conduzida, que leva a uma escalada altíssima da produção (a tal "altura do sarrafo"), processo que comumente é denominado de "produtivismo". (RECHIA et al, 2015, p. 11).

Os professores da área sociocultural também tem se sujeitado a produção coletiva, embora seja em uma menor proporção, perceberemos que de 2000 a 2004 a publicação de artigos com somente 1-2 autores era maioria, posteriormente os trabalhos com mais de três 
autores aumentam, lógica essa que tem se perpetuado para que os professores consigam se manter na pós-graduação.

\section{GRÁFICO 3 - QUANTIDADE DE AUTORES POR ARTIGOS NA LINHA DE PESQUISA DA ÁREA SOCIOCULTURAL}

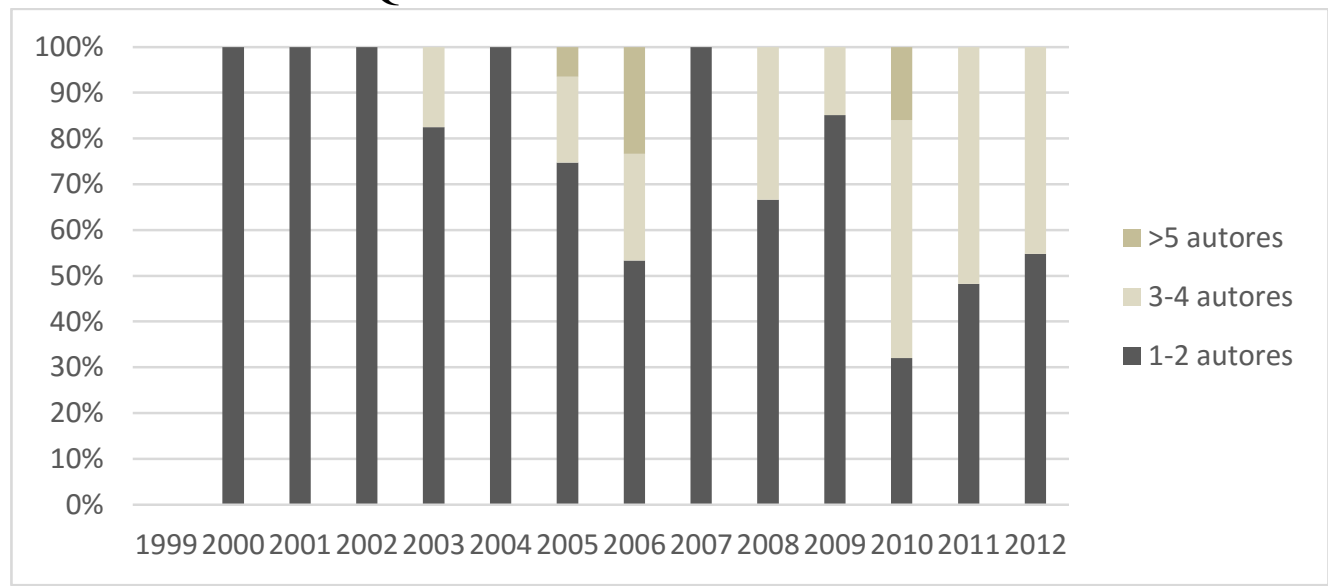

FONTE: STIGGER, SILVEIRA, MYSKIW (2015, p. 25).

O gráfico acima representa a quantidade de autores por artigo que compuseram as pesquisas sociocultural dos anos de 2000 a 2012. Percebe-se que foi significativo o aumento no número de autores por artigo com o passar dos anos, a realidade dos programas perpassa por colaboradores para submissão dos artigos, torna-se evidente que se nos atermos aos anos de 2000, 2001, 2002, 2003, 2004 são prevalentes os trabalhos com 1 - 2 autores e somente 18\% de trabalhos com 3 - 4 autores, por mais que a lógica de expansão já estivesse vigorando, esse primeiro período estava em transição. Nos anos de 2005, 2006 e 2010 percebe-se que trabalhos com até cinco autores foram publicados, embora as quantidades fossem bem menores em relação às biodinâmicas.

Ao compararmos o ano de 2009 em relação a 2008 perceberemos que há um maior número de trabalhos publicados com $1-2$ do que 3 - 4 autores, embora nesse período a vigência ainda correspondesse V PNPG e a lógica de expansão estivesse vigorando, sendo assim que houveram sim impactos na lógica de produção na área sociocultural, não tanto quanto nas biodinâmicas ${ }^{133}$.

\footnotetext{
${ }^{133}$ Lazarotti et al. (2012, p, 1-3) nos apresenta também essa prevalência das ciências duras em relação as ciências moles, "A prática de pesquisa na Educação Física é recente no Brasil e sua incorporação no cotidiano desse campo é mais recente ainda, trazendo consigo outros aspectos do fazer científico, como é o caso da necessidade da veiculação dos resultados dessas pesquisas. Assim, entram em cena com maior protagonismo as revistas científicas, tradicional veículo de comunicação de uma comunidade científica. [...]Nos 223 textos analisados identificou-se, a partir da exclusão de sete textos publicados em língua estrangeira, a média de 3,32 autores por texto. Também se identificou que a autoria compartilhada vem se apresentando como preferência dos investigadores da Educação Física, principalmente na RBCDH $(4,2)$, RBAFS $(4,2)$ e REF-UEM $(4,1)$. Na Tabela 1 observa-se que apenas $19(8,6 \%)$ textos são de autoria individual. Enquanto as revistas RPP, RM e RL
} 
Na realidade, o que se percebe com estratégias dessa natureza, é um investimento no sentido de "jogar o jogo com o livro de regras em baixo do braço", expressão bastante recorrente nesse universo, que atribui outros significados às formas de vigilância e classificação. Ela poderia ser interpretada não exatamente como a busca do aumento da produção do conhecimento em Educação Física, mas como uma forma de "gestão da visibilidade da produção" (ou "da pontuação"), em que conhecer o sistema (transitar nele e fazer uso das possibilidades que ele oferece para obter sucesso) acaba sendo tão, ou mais importante do que efetivamente produzir conhecimento. (STIGGER; SILVEIRA; MYSKIW, 2015, p. 31).

Confirmando a lógica produtivista, o relatório trienal 2010/2012 demonstra o levantamento da produção intelectual em um gráfico comparativo dos triênios 2007/2009 e $2010 / 2012$

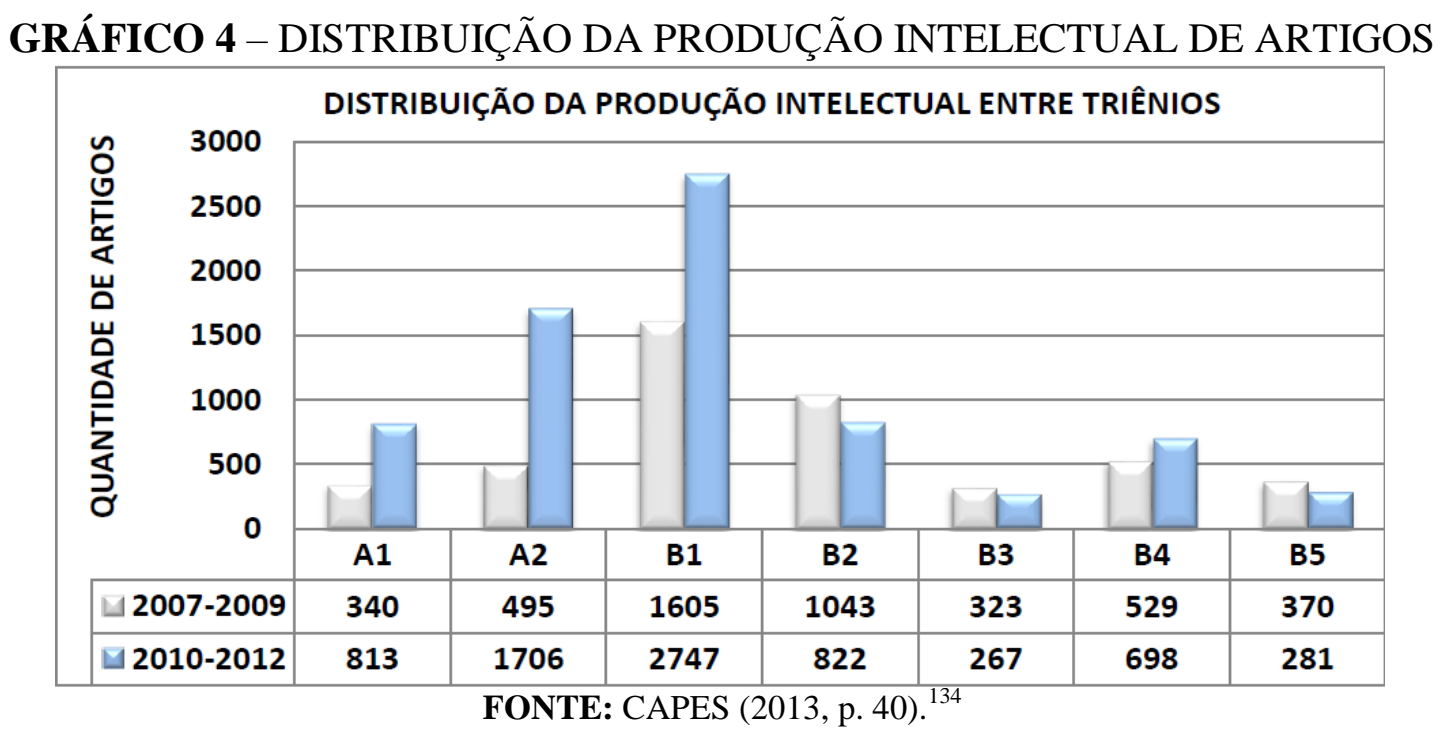

Um dos itens inseridos no presente processo visou valorizar a proporção de artigos e livros publicados nos estratos superiores $(>\mathrm{A} 2,>\mathrm{L} 3,>\mathrm{C} 3)$ e buscou qualificar as quantidades de produtos. Esse item teve peso igual aos indicadores puramente quantitativos (média e mediana; 20\%). A proporção de artigos em estratos acima de A2 revelou que a área produziu 1/3 de seus produtos em estratos superiores, mais uma vez destacando a melhoria qualitativa das publicações. É notória nesse sentido a clara participação dos cursos de conceito mais elevados nesse item. Recomenda-se aos programas a preferência de publicação em revistas de maior estratificação quando conceitos mais elevados constituem objetivos dos programas - preservada a aderência desses itens de publicação. (CAPES, 2013, p. 42).

possuem a maior percentagem de artigos com autoria individual $(12,5 \%, 22,5 \%$ e 47,6\%, respectivamente), os percentuais mais baixos de autoria individual foram observados nas revistas RBEFE (0\%), RBCDH (1,9\%), REF-UEM (1,9\%), RBCE (3,8\%) e RBAFS (6,3\%)". O histórico da Educação Física, que se amparou no positivismo possui fortes influências até hoje, como é notado pelas pesquisas.

${ }^{134}$ Esses valores correspondem a todas as áreas que correspondem a Área 21, não foi possível fazer um comparativo somente da Educação Física, pois, os resultados individuais foram apresentados conceitualmente. 
Nota-se que de um triênio para outro há tanto aumento quanto diminuição no número de artigos publicados. No que diz respeito aos artigos publicados nos periódicos ${ }^{135}$ A1, A2, B1 tanto a variação absoluta, quanto a variação relativa foram significativamente aumentadas. A1 houve um aumento de 473 artigos, o que corresponde a 139,11\% em relação ao período anterior; A2 houve um aumento de 1211 artigos, o que corresponde a 244,64\% em relação ao período anterior; B1 houve um aumento de 1142 artigos, o que corresponde a 71, 15\% em relação ao período anterior.

Esse aumento de artigos publicados nos periódicos A1, A2 e B1 se devem a alguns fatores, indexação, fator de impacto ${ }^{136}$, bem como aumento da representatividade da área de acordo com o quesito 'qualidade' da CAPES, bem como a internacionalização.

Kuenzer e Moraes (2005) criticam essa lógica da produção acadêmica, segundo as autoras essas exigências das políticas de pós-graduação tem provocado um surto produtivista que o 'importante' é publicar, não importa se a versão seja 'requentada', a quantidade passa a ser instituída como meta, sendo desconsiderada a qualidade ${ }^{137}$.

\footnotetext{
135 "No universo acadêmico brasileiro a referência para categorizar qualitativamente a produção científica vincula-se principalmente - mas não exclusivamente - à avaliação da qualidade dos periódicos nos quais essa produção está disponibilizada. Desse exame decorres a categorização e hierarquização dos pesquisadores e dos programas de Pós-Graduação, o que se sustenta no reconhecimento (maior ou menor) que a eles seja atribuído, levando-se em conta os critérios construídos e praticados no contexto do sistema de avaliação. Isso é desenvolvido pelo Qualis, um "conjunto de procedimentos utilizados pela CAPES para estratificação da qualidade de produção intelectual dos programas de pós-graduação. Tal processo foi concebido para atender às necessidades especificas do sistema de avaliação [...]. Como resultado, disponibiliza uma lista com a classificação dos veículos utilizados pelos programas de pós-graduação para a divulgação da sua produção". Sendo atualizada periodicamente, essa lista oferece uma pontuação para cada periódico, o que indicará o "valor" de cada artigo, de acordo com a classificação atribuída à revista na qual ele está publicado. As revistas mais valorizadas são aquelas que estão mais bem classificadas no Qualis, o qual leva em consideração, de forma especial, as bases de dados em que os periódicos estão indexados". (STIGGER; SILVEIRA; MYSKIW, 2015, p. 33).

${ }^{136}$ Segundo Patriarca (2012, p. 109) O quesito da "qualidade" é questionável, pois não há uma avaliação do conteúdo da produção intelectual. Os periódicos científicos são, então, classificados de acordo com sua indexação em base de dados, bem como o fator de impacto49 de suas publicações, o que resulta em 8 níveis, já bem conhecidos entre os professores da pós-graduação, são eles: A1, A2, B1, B2, B3, B4, B5 e C. [...]O fator de impacto é uma medida questionável e pouco confiável, pois é mensurado a partir da quantidade de citações que determinado artigo recebeu, não considerando se as citações foram em concordância ou como objeto de crítica.

${ }^{137}$ Segundo Kuenzer e Moraes (2005, p. 1349) "Em relação à exacerbação quantitativista registre-se, ainda, a ação reguladora da CAPES no tempo de duração dos cursos. O controle do tempo médio de titulação, articulado à política de concessão de bolsas, embora tenha desempenhado importante papel no redimensionamento dos excessivamente longos tempos de conclusão do mestrado e de doutorado, também forjou seu contrário: em particular, o aligeiramento do mestrado, considerado, agora, formação inicial em pesquisa a ser complementada no doutorado. Assim, a necessária redução nos tempos médios de titulação se sobrepôs, em grande medida, à qualidade da formação, principalmente no mestrado. Neste nível, a inexperiência em pesquisa, articulada à não rara fragilidade da formação teórica anterior, demandaria um tempo maior para o amadurecimento acadêmico de grande parte dos alunos. Sob o impacto das exigências da avaliação CAPES e da concessão de bolsas, pelo menos no caso da Educação, os programas de pós-graduação assumiram como meta titular de qualquer forma e a qualquer custo - em 24 ou 48 meses. Neste processo, as condições reais de trabalho dos alunos passaram a segundo plano. O percurso curricular confrangido supõe um aluno idealizado - de modo preferencial os que trazem experiência de bolsas de iniciação científica - com suficiente autonomia intelectual para dominar as
} 
No triênio de 2007/2009 já foi considerada a avaliação de livro, de maneira mais simples, mais ocorreu, já no triênio de 2010/2012 essa avalição ocorreu de maneira mais elaborada, considerando a produção intelectual de livros e capítulos em livros. Essas considerações acerca da avaliação de livros aconteceu como forma de resposta às ciências sociais. Lazarotti et al. (2012) afirmam que as chamadas "ciências duras" preferem a artigos científicos do que livros, enquanto as áreas que estabelecem relações com as chamadas "ciências moles" preferem a livros.

Em sendo assim, foi criada uma comissão e um regulamento para sua avaliação e estabeleceu que os livros fossem classificados nos estratos de L1 a L4, sendo que a pontuação deve ser atribuída aos aspectos formais, tipo e natureza da obra; vinculação à Área do Conhecimento e; avaliação de seu conteúdo. (PATRIARCA, 2012, p. 112).

A partir dos dados de identificação da obra, da avaliação da comissão de livros e da avaliação do conteúdo da obra, uma estratificação ${ }^{138}$ é direcionada para cada obra, a partir de então a avaliação de livro passou a ser considerada na avalição da capes, no critério produção intelectual. No triênio 2010/2012 a área considerou a avaliação de livros para dimensionar a mediana da produção.

\section{GRÁFICO 5 - DISTRIBUIÇÃO DA PRODUÇÃO INTELECTUAL DE LIVROS (L4 a L1) E CAPÍTULOS (C4 a C1)}

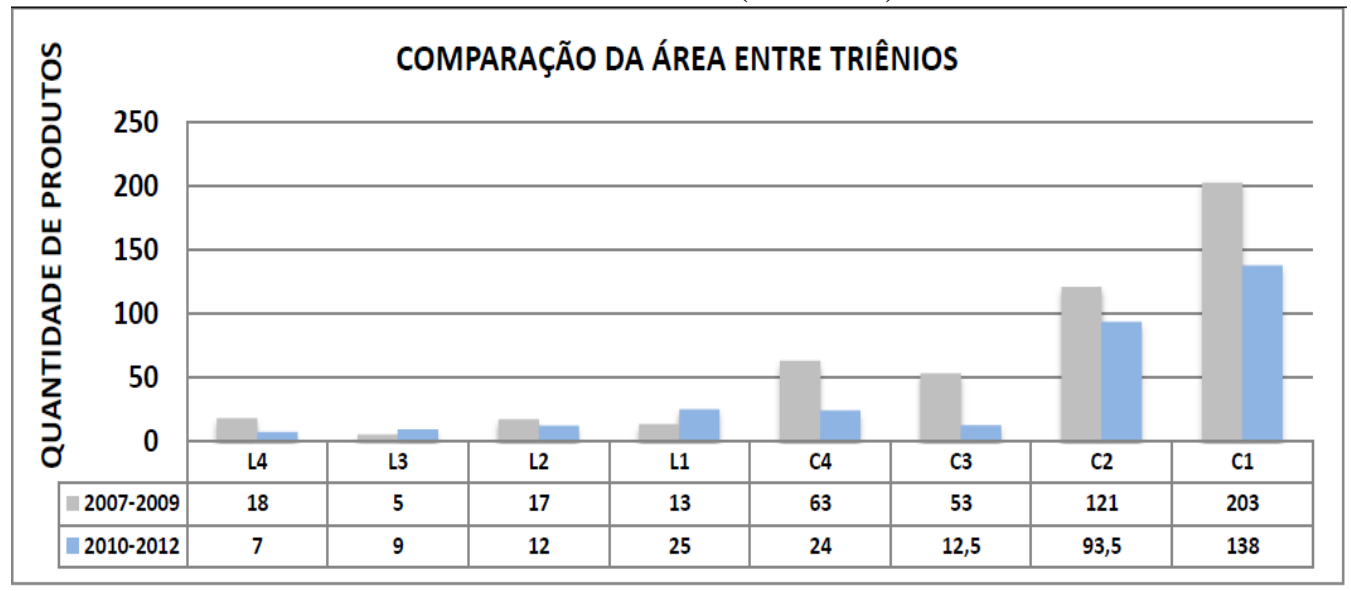

FONTE: CAPES (2013, p. 41).

categorias teórico- metodológicas em um ano, e com condições para finalizar a "pesquisa" ao final do segundo ano, admitida uma extensão de mais seis meses de prazo para os não bolsistas".

${ }^{138}$ L4 - $100 \%$ da pontuação atribuída ao livro, L3 - 75\% da pontuação atribuída ao livro, L2 - 50\% da pontuação atribuída ao livro, L1 - 25\% da pontuação atribuída ao livro, LNC - não receberá pontuação como produção científica. (CAPES, 2013). 
O gráfico acima apresenta a distribuição da produção de livros e capítulos de livros de acordo com a estratificação utilizada para avaliação de livros. Ao analisar o gráfico percebemos que os livros avaliados como L4, se compararmos o triênio de 2010/2012 em relação ao triênio 2007/2009 percebemos um decréscimo na quantidade de livros, já no que se refere aos livros avaliados como L3 percebemos um aumento na quantidade; se tratando dos livros avaliados como L2 houve um decréscimo na quantidade e L1 houve um acréscimo na quantidade. Sendo assim,

[...] Os livros e capítulos corresponderam 53 e 238 itens de produção. Além disso, a média e a mediana da área, tiveram aumentos expressivos e saíram de 500 e 300 pontos para 600 e 400 pontos, respectivamente. [...] A área optou por dimensionar a quantidade de produtos publicados pelos programas pela média e mediana (com pesos de 5 e $15 \%$, respectivamente), além da proporção de artigos publicados nos estratos superiores (> A2, > L3 e >C 3). A média e a mediana dos programas da subárea da Educação Física foi bastante discrepante, o que confirma a maior heterogeneidade identificada ao longo dos seminários de acompanhamento, quando comparada com as subáreas de Fonoaudiologia e Fisioterapia que foram mais homogêneas em termos de produção intelectual. (CAPES, 2013, p. 40-41, Grifos nossos).

\section{GRÁFICO 6 - MEDIANA DOS PONTOS DA PRODUÇÃO INTELECTUAL DOS PROGRAMAS DA ÁREA 21 NO TRIÊNIO 2010/2012*}

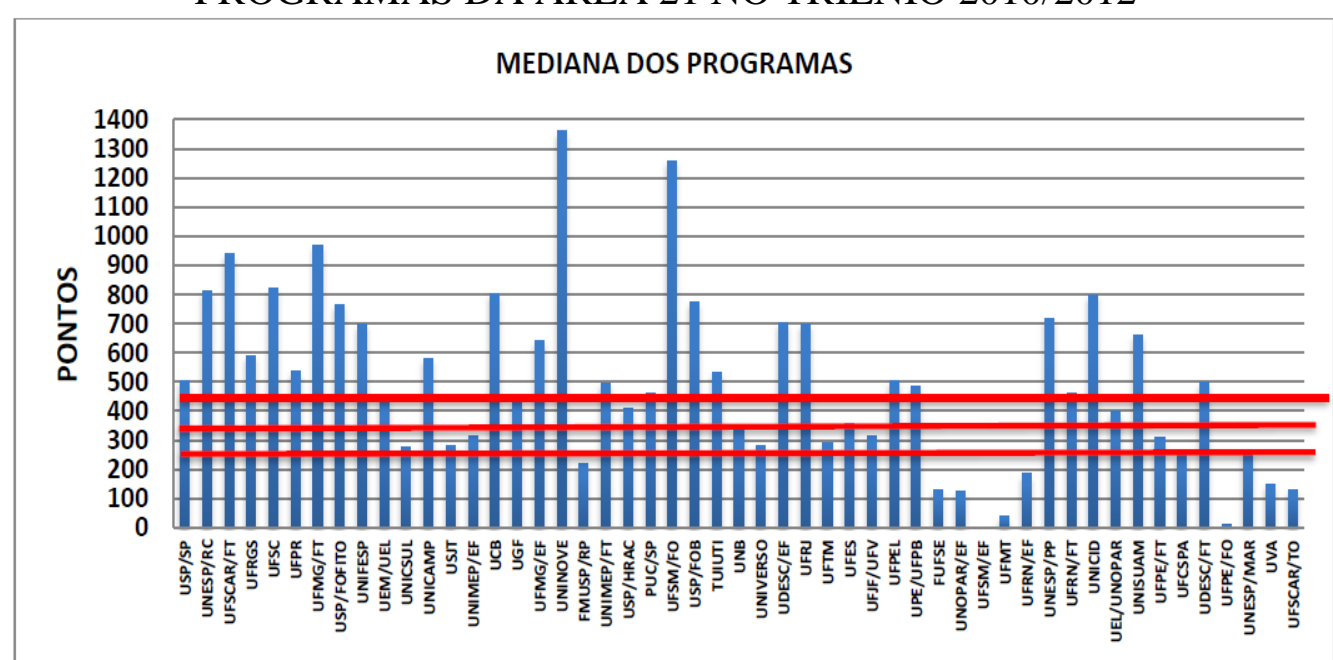

FONTE: CAPES (2013, p. 41).

*Métrica: $\mathrm{MB}=>450 ; \mathrm{B}=>350 ; \mathrm{R}=>250 ; \mathrm{F}=>200 ; \mathrm{D}<200$.

O gráfico acima corresponde à mediana da pontuação de todos os programas da área 21 no triênio de 2010/2012, percebemos que no que se refere aos cursos de pós-graduação em Educação Física há uma significativa oscilação, cursos que não atingiram 100 pontos, como a UFMT e UFSM, e cursos que atingiram 700 e 800 pontos como a UDESC, UFRJ e a UCB. Se comparado a dois programas da Fisioterapia (UNINOVE e UFSM) a pontuação 
corresponde ao dobro da produção máximas dos programas de Educação Física, dessa maneira se torna perceptível a necessidade de repensar as condições de subáreas que compõe a Educação Física.

\section{GRÁFICO 7 - MÉDIA DOS PONTOS DA PRODUÇÃO INTELECTUAL DOS PROGRAMAS DA ÁREA 21 NO TRIÊNIO 2010/2012*}

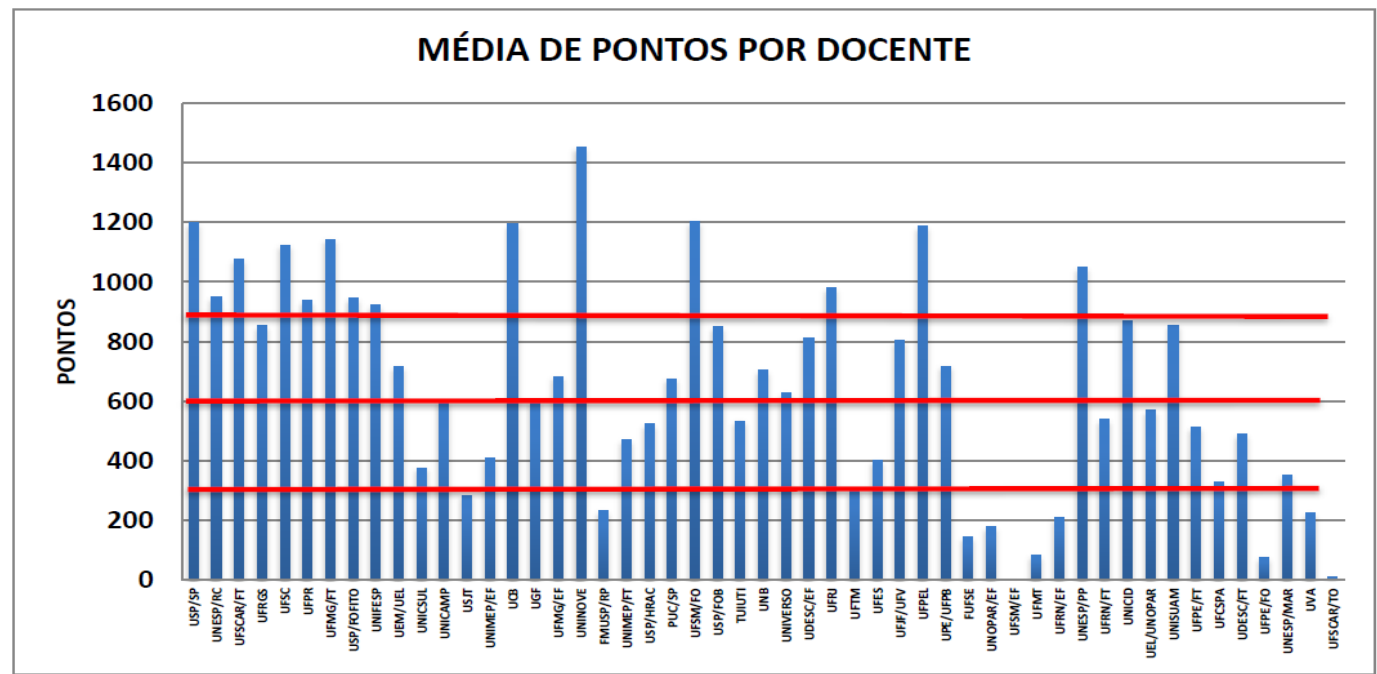

FONTE: CAPES (2013, p. 42).

*Métrica: $\mathrm{MB}=>900 ; \mathrm{B}=>600 ; \mathrm{R}=>300 ; \mathrm{F}=>100 ; \mathrm{D}<100$.

O gráfico acima representa a média de pontos por docente referente a todos os programas da área 21 correspondente ao triênio 2010/2012. Ao observarmos o gráfico perceberemos que três cursos da Educação Física se sobressaíram, USP, UCB e UFPEL, corresponderam em média a 1200 pontos por docente, essa média contribui expressivamente para o 'aumento do sarrafo', pois quanto mais se produz mais a mediana dos programas também aumenta. Sendo assim,

[...] percebemos que o processo de construção do campo científico da Educação Física e da sua lógica de avaliação não se dá de forma abstrata, mas no âmbito das relações concretas entre diferentes agentes que fazem parte desse universo acadêmico plural e multifacetado. Assim, mesmo que muitas vezes ouçamos que "a Capes somos nós", o que as observações que fizemos nos levam a afirmar é que esse "nós" não tem se mostrado homogêneo e consensual, mas profundamente heterogêneo e constituído por conflitos e por relações de poder, com logicas de funcionamento e repercussões que nem sempre estão claras para todos os participantes.

Em relação às medianas e médias anteriores, essas foram as maiores obtidas pela área 21, impactando diretamente nas notas dos programas. O quesito notas é apresentado no critério Inserção Social, pois, são relevadas as ações dos programas em relação à expansão, no 
triênio 2010/2012 percebe-se uma elevação das notas dos programas da área 21, embora dois programas tenham sidos descredenciados, um mestrado acadêmico por não apresentar estabilidade do corpo docente e um mestrado profissional, ambos pelos critérios de avaliação da CAPES não apresentaram produção suficiente para permanecerem credenciados.

\section{GRÁFICO 8 - VARIAÇÃO ENTRE AS NOTAS EM RELAÇÃO AOS TRIÊNIOS} ANTERIORES (2007 - 2010 E 2013)

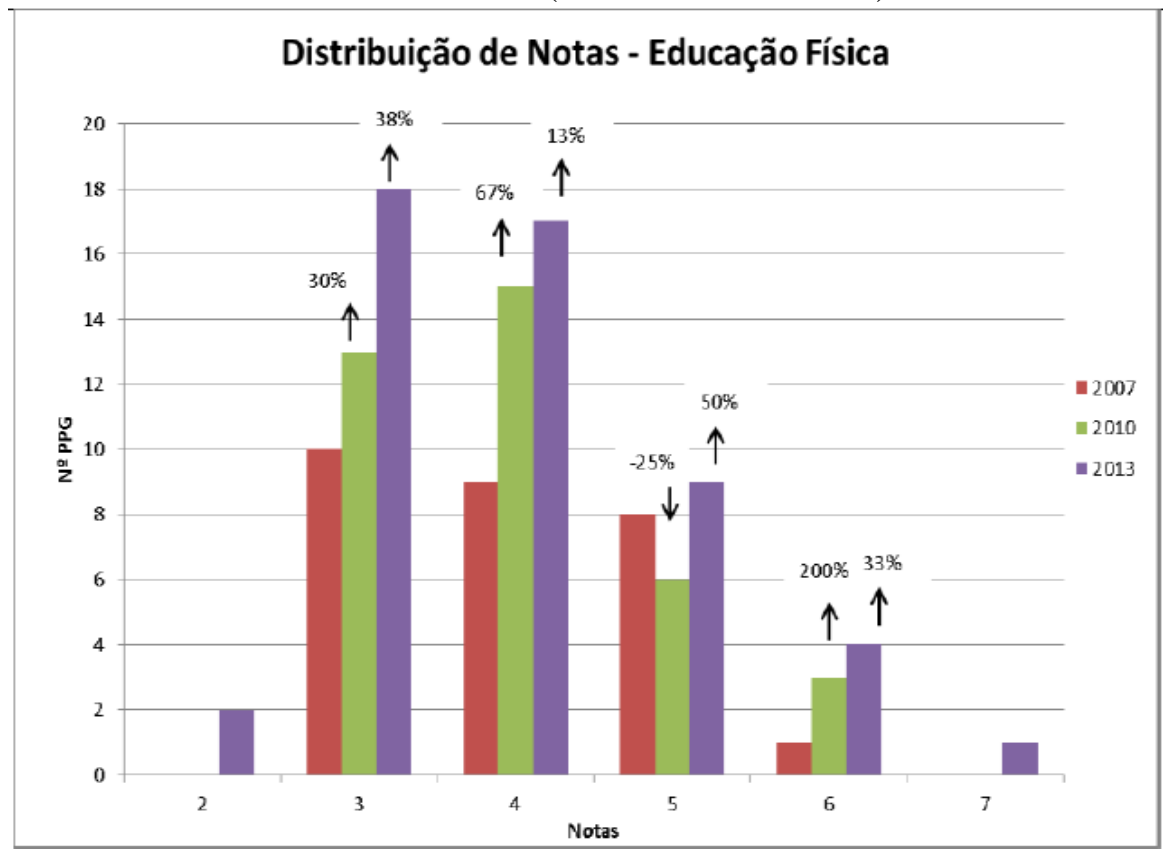

FONTE: CAPES (2013, p. 3).

O gráfico acima apresenta a variação das notas dos programas de pós-graduação da área 21 no período de 2007 - 2012. No que diz respeito às notas dos cursos, percebe-se que no triênio 2010-2012, a quantidade de cursos com notas 5 e 6 aumentaram, e pela primeira vez um curso atendeu todos os critérios de avaliação com 100\% de aproveitamento, portanto foi pontuado com nota 7. Do total de cursos de pós-graduação avaliados na área 21, 51 cursos, 49\% desse total mantiveram, 37\% aumentaram e 14\% diminuíram suas notas em relação ao triênio 2007/2009.

Com esse levantamento de dados percebe-se que as políticas de avaliação da CAPES influenciam diretamente para a expressão da miséria da razão no contexto da pós-graduação, no que diz respeito à Educação Física, a hegemonia das biodinâmicas tem influenciado diretamente para o 'aumento do sarrafo', sendo assim alguns movimentos de contra hegemonia tem sido levantados para repensar essas questões apresentadas no decorrer do trabalho. 
Os Fóruns de Pós-Graduação do Colégio Brasileiro de Ciências do Esporte, desde 2012 tem se reunido para discutir e problematizar esses desafios acerca da pós-graduação, em 2015 foi organizado um livro que considerou dois dos seis fóruns que já foram realizados, foram considerados os fóruns de 2012, realizado em Florianópolis com o tema: PósGraduação em Educação Física: atualidades e perspectivas para o futuro o de 2014 foi realizado no Espírito Santo com o tema: Desafios e Dilemas da Pós-Graduação em Educação Física na Área 21. (RECHIA et al., 2015).

O livro apresenta uma coletânea de textos que problematizam os desafios que a área da Educação Física tem enfrentado em relação aos determinantes da pós-graduação. “[...] A intenção, de um lado, é sinalizar a busca de novos caminhos; de outro, construir uma estratégia política/acadêmica/científica que promova o avanço qualitativo da produção dos programas de Pós-Graduação em Educação Física”. (RECHIA et al., 2015, p. 12).

Outro movimento que tem ocorrido é a migração de professores da área para os programas de pós-graduação de Educação, isso porque o aumento de pontos influi diretamente na manutenção dos professores dentro dos programas de pós-graduação, como a hegemonia se dá a partir das biodinâmicas o 'sarrafo' influencia diretamente na área sociocultural, portanto, dificultando que os professores afins permaneçam credenciados.

Por fim, outro movimento que vem sendo problematizado e sugerido é a criação de uma educação física dois, Bracht (2015, p. 120) apresenta a idéia da seguinte maneira,

\footnotetext{
Aqui gostaria de propor outra alternativa: organizar a área em dois campos dialogantes, mas distintos. O das Ciências do Movimento, que poderia continuar vinculada à grande área da saúde, ou migrar para grande área multidisciplinar (talvez o mais indicado) e a área da EF (e a do Esporte e outros campos profissionais) que migraria para a área de "Ensino de..." vinculada à grande área multidisciplinar. Nessa área a EF poderia tanto manter cursos de Mestrado/Doutorado acadêmicos como de Mestrado profissional. (BRACHT, 2015, p. 122).
}

Sendo assim é fundamental que mais pesquisas apresentem sistematizações e criticas sobre as expressões da decadência ideológica na pós-graduação em Educação Física para que mais alternativas sejam apresentadas e as que se encontram postas sejam problematizadas, pois, a lógica da acumulação flexível este sendo reproduzida pela CAPES, consequentemente a produção tem se tornado sinônimo de quantidade ao invés de qualidade, portanto, refletindo as determinações da miséria da razão, como o agnosticismo e a práxis manipulatória. 


\section{CAPÍTULO IV}

\section{CONSIDERAÇÕES FINAIS}

A pretensão desse percurso investigativo se deu a partir da reconstituição da decadência ideológica e suas implicações no contexto da Pós-graduação, principalmente no que se refere à pós-graduação em Educação Física. No segundo momento apresentamos as expressões reais da miséria da razão e seus vínculos com o capitalismo contemporâneo. No terceiro momento apresentamos as análises dos documentos da área, sendo assim compreendemos que

[...] Na realidade, o desenvolvimento social é uma unidade de contradições, viva e dinâmica; é a ininterrupta produção e reprodução destas contradições. Acrescente-se a isto que todo ideólogo, não importa de que classe provenha, está de modo hermético e solipsista aprisionado no ser e na consciência de sua classe apenas para a sociologia vulgar; na realidade, porém, está sempre em face da sociedade como um todo. (LUKÁCS, 2010, p.70)

As contradições de que trata Lukács (2010) não se referem apenas ao que transcorre a burguesia e o proletariado, mas também aquelas que permeiam internamente a classe capitalista. Se os indivíduos compreendessem a densidade das contradições dessa formação social, a emancipação humana poderia se fazer alcançável.

De acordo com Lukács (2010), a possibilidade de desenvolvimento dos indivíduos da classe burguesa rumo à emancipação humana pode acontecer: [...] A burguesia possui somente a aparência de uma existência humana. Entre aparência e realidade, portanto, deve surgir em cada indivíduo da classe burguesa uma viva contradição [...] (Ibidem, p. 70). Todavia, o que os ideólogos burgueses fazem está profundamente articulado a naturalização dessas contradições, contribuindo ainda mais com as condições de alienação humana.

O processo de decadência da filosofia e da economia política se infiltra no pensamento social, pois o movimento histórico vai a desfavor a ideia da ideologia burguesa. Esta ideia aponta para condições de fragmentação do conhecimento. [...] Nessa medida, o sentido da 'decadência ideológica' é a contraface - absolutamente necessária - do brutal desenvolvimento material e tecnológico deflagrado a partir daí [...] facilitando, assim, as tradições apologéticas nas ciências sociais e nas ciências naturais. Destarte, [...] o seu comprometimento passa a se estabelecer tão somente com a reprodução incessante da 
estrutura sociometabólica do capital, mitigando as resistências e amaciando o curso do controle (PINASSI, 2009, p. 16).

Após a instauração da decadência ideológica, muitas foram às tendências que não se preocupavam com a modernidade social ${ }^{139}$ deixando explícito os reflexos da decadência nas ciências sociais e naturais. Nas ciências sociais, por mais que haja um trabalho sério e verdadeiramente científico, os ideólogos burgueses ainda conseguem se abordar a apologética e a reprodução. Nas ciências naturais, segundo Lukács (2010, p. 72), a situação se agrava pela reprodução reduzida à técnica em que [...] o terrorismo filosófico da burguesia atual intimida o materialismo espontâneo de importantes cientistas e os obriga a meditar e expressar as consequências materialistas de suas descobertas apenas de modo vacilante, hesitante, diplomático.

A evolução da decadência fez com que a arte e a literatura ocupassem um lugar diferenciado em relação às ciências sociais e naturais. A sinceridade artística permite ao proletariado um gral de 'liberdade' que nas ciências naturais já não mais se encontra. A respeito da literatura, do ponto de vista imediato, esta somente enfatiza as reais condições sociais em última instância, porém, as contradições internas da sociedade burguesa são as condições para o desenvolvimento da literatura.

Essa possibilidade de liberdade artística e da literatura acontece até o momento em que a burguesia se apropria de tais obras ocasionando um movimento pseudo-revolucionário o qual domestica até mesmo as interpretações. Quando isso acontece, cabe ao escritor e ao artista se saturar de determinações em relação à sociedade, pois quanto mais estes se aprofundarem e conhecerem as deformações sociais, [...] tanto mais os problemas centrais passam ao primeiro plano de seus interesses [...] (LUKÁCS, 2010, p. 75).

Portanto, para que o processo dialético ocorra é fundamental que o autor se vincule totalmente a análise da realidade. Com o progredir da decadência, a relação entre autor e realidade foi distanciada gerando transições de renomados autores para a apologética e compartilhando da corrupção da realidade de forma naturalizada. Se tratando dos autores que não partilham dessa lógica, é de extrema relevância entender que [...] A sinceridade subjetiva,

\footnotetext{
${ }^{139}$ Entendemos por modernidade social a constante transformação da ordem burguesa: [...] A burguesia não pode existir sem revolucionar permanentemente os instrumentos de produção - nesse mesmo sentido as relações de produção e consequentemente as relações sociais [...] A continua subversão da produção, o ininterrupto abalo de todas as condições sociais, a permanente incerteza e a constante agitação distinguem a época da burguesia de todas as épocas precedentes [...] Tudo é sólido e estável se dissolve no ar, tudo o que era sagrado é profanado e os homens são, enfim, obrigados a encarar, sem ilusões, a sua posição social e as suas relações recíprocas [...] (MARX; ENGELS, 1998, p. 8).
} 
por certo, é condição imprescindível para o triunfo do realismo, mas fornece apenas sua possibilidade abstrata, não a possibilidade concreta (LUKÁCS, 2010, p. 76).

Torna-se notório que a concepção de mundo focada pela decadência é justamente para atrapalhar e dificultar aos escritores o acesso às contradições da realidade, imersos a um processo em que toda a literatura da decadência (do naturalismo ao surrealismo) possuíam/em um objetivo em comum, a luta contra o "realismo autêntico". Dessa forma segundo Lukács (2010, p. 103),

[...] Jamais se repetirá suficientemente, com a necessária frequência e energia, que a tendência à decadência não constitui uma fatalidade para o escritor como indivíduo, mas sim como um problema social normal. Certamente, quanto mais tenha progredido a decadência ideológica geral, tanto maiores serão as exigências intelectuais e morais que se colocam ao escritor que não pretenda capitular diante da decadência, que queira abrir caminho para o verdadeiro realismo. Um caminho que é um perigoso atalho, circundado por trágicos abismos. Contudo, ainda mais intensamente se destaca a grandeza daqueles escritores que, em épocas tão pouco favoráveis, lograram abrir caminho para o verdadeiro realismo. (LUKÁCS, 2010, p. 103).

Imersos a essa conjuntura da decadência, a cada dia que passa é mais complicado a sinceridade objetiva, o verdadeiro realismo. Ela não é o que de fato abarca aos escritores burgueses. Estes se atêm, a princípio, a uma visão adstrita da realidade e de suas relações restringindo-se a não denunciar as contradições, conscientemente ou não. Depois, utilizam de um realismo espontâneo. Sobre este espontaneísmo, não se sabe até que ponto ele contribuiu ou não para o adensamento de uma visão de mundo crítica, [...] no caso de um contraste entre a realidade corretamente percebida e vivida, por um lado, e, por outro, a ideologia e os preconceitos adquiridos (LUKÁCS, 2010, p. 77).

A ideologia e os preconceitos desse período afastam o foco dos homens impedindo que eles percebam de fato o que é ou não importante. Isto se deve aos resíduos ideológicos do capitalismo decadente. Para que o realismo ocorra é fundamental que os preconceitos se afastem da própria realidade, em primeiro lugar, e posteriormente da alma. Deste modo é gerado um processo de ação e reação, e "[...] A quantidade e a qualidade dos preconceitos que o escritor deve superar, sem nenhuma dúvida, crescem com o agravamento da decadência ideológica [...]" (Ibidem).

Nesse conturbado quadro histórico que resulta a alienação da generalidade do homem e de sua essência, a criação e contentamento de novas necessidades alienadas passam a ser a força motriz. As necessidades se tornam apenas individuais, cedendo espaço a uma essência egoísta e de rápidas paixões, paixões que correspondem somente ao "ter". Surge, 
então, uma tensão entre o burguês e o cidadão na qual as ações coletivas direcionadas para a essência particular manifestando a singularidade extrema. Os meus desejos se sobrepujam aos da coletividade e, dessa forma, as necessidades reais, as que de fato efetivam a essência do ser social, ficam a mercê da distorção pela capitulação da propriedade privada, da riqueza e do dinheiro (ALVES, 2015).

Percebemos por meio das análises que as determinações políticas sobre os programas de pós-graduação têm gerado uma real expressão da miséria da razão, sendo a tecnocracia, a burocratização e o produtivismo essas expressões. Sendo assim, verificamos que muitos são os fatores que contribuem para o 'aumento do sarrafo':

- o aumento dos programas de pós-graduação, as políticas de expansão determinadas pelo VI PNPG influenciaram diretamente, com esse aumento uma das consequências evidente são disputas internas por status dos programas;

- o aumento dos programas de mestrado/doutorado em relação aos de mestrado e criação do primeiro mestrado profissional da área; os programas de M/D aumentaram em relação aos de M também por determinações das políticas de expansão do VI PNPG, no que se refere a MP as determinações de expansão tem como objetivo o Ensino Básico, sendo assim, os mestrados profissionais estão se espalhando pelo país para o atendimento dessa demanda.

- com esse processo de expansão nota-se uma tradição das regiões sudeste e sul em relação às demais, tornando-se evidente uma expressiva produção dessas regiões e consequentemente um destaque maior para seus programas;

- com o aumento dos programas o número de docentes também aumentou, porém, ao compararmos com a produção intelectual percebe-se que o número de artigos produzidos é muito maior do que o número de docentes, portanto, o número de artigos publicados por docente aumentou significativamente;

- por fim as exigências acerca das notas dos programas, a partir dos triênios analisados percebemos que as notas aumentaram, porém as que se mantém em relação ao triênio anterior aparecem em maior número, no triênio 2010/2012 a área 21 se sobressaiu, pois atingiu o padrão internacional de acordo com os critérios de avaliação da CAPES.

Esses fatores desembocaram em outros determinantes como: a segregação da área com prevalência das ciências duras, essas contribuem diretamente para o 'aumento do sarrafo'; adoecimento dos docentes devido à pressão em função da produção e atendimento das demandas burocráticas e adoecimento dos discentes para cumprimento do TMT e atendimento da produção, não só do produto final, mais da produção em periódicos. 
Tudo isso por que a lógica da acumulação flexível este sendo reproduzida pela CAPES, consequentemente a produção tem se tornado sinônimo de quantidade ao invés de qualidade, portanto, refletindo as determinações da miséria da razão, como o agnosticismo e a práxis manipulatória.

Marx (1974) problematiza, sinteticamente, a separação entre sujeito e objeto, sendo fundamental [...] O superar, como movimento objetivo que retoma a si a alienação. É esta a concepção que se expressa no interior da alienação, da apropriação da essência objetiva mediante a superação da alienação [...] (p. 44). A interação com o mundo objetivo permite que o homem se humanize. Quando o mundo torna-se real, o sujeito estabelece relações, relações estas que propiciam uma natureza humanizada. O homem ao se relacionar humanamente com mundo objetivo supera a alienação de si mesmo representando o regresso do homem a sua condição de ser social.

\footnotetext{
A capacidade de atingir um tal conhecimento intimo do homem é o triunfo do realismo na literatura. É evidente que um escritor pode se abrir para uma tal concepção do homem somente quando houver superado, em si mesmo, os preconceitos equivocados que a burguesia divulga sob as mais variadas formas a respeito do homem e do mundo, do indivíduo e da sociedade, da vida interior e exterior da pessoa humana. (LUKÁCS, 2010, p. 81)
}

Sendo assim, quando retomamos as leituras de Marx nos deparamos com as probabilidades para motivação da prática revolucionária, pois o conteúdo da obra marxiana permite a alteração das condições objetivas dos sujeitos. Tem-se daí a importância de retomarmos os fundamentos do humanismo marxista, pois além de investigador do problema do indivíduo humano, era um lutador pela felicidade (SCHAFF, 1967).

O homem nasce na sociedade burguesa, sendo submetido a determinadas condições sociais, condições essas que ele não escolhe e que são determinadas pela produção, sendo assim [...] ergue-se toda a complicada estrutura de concepções, sistemas de valores $e$ instituições ligadas a ela [...] (SCHAFF, 1967, p. 71). Sendo assim, [...] o homem não é um ser abstrato, acocorado fora do mundo. O homem é o mundo do homem, o Estado, a sociedade [...] (MARX, 2003, p. 151; Grifos do autor). Além de estar ligado ao mundo e a sociedade, o homem também é constituído e criado por este mundo, sendo as condições sociais determinantes para a constituição do indivíduo humano.

Neste contexto, quanto mais se saturar o objeto de determinações maiores serão as possibilidades de mediações com a realidade, facilitando assim as condições de emancipação dos sujeitos. Assim, [...] Investigar, para Marx, é buscar essas determinações do objeto. $O$ conhecimento do objeto é tanto maior quanto maior forem as determinações encontradas, ou 
seja, quanto mais se satura o objeto com determinações maior é o conhecimento a respeito dele (HÚNGARO, 2008, p. 87).

O segredo está em despertar no homem a necessidade real de reconhecer-se no outro, sendo assim [...] A verdadeira riqueza espiritual do indivíduo depende inteiramente da riqueza de suas relações reais [...] (MARX apud LUKÁCS, 2010, p. 81). A partir do momento que suas relações se tornam superficiais desembocamos em um imediatismo sem fim, se tornando a literatura o retrato do esvaziamento e um campo de experiências formalistas. [...] Desta essência da literatura, decorre o problema da substancial moralidade social do escritor realista e da importância de sua honestidade, de sua energia e de sua coragem. [...] (LUKÁCS, 2010, p. 82).

É fundamental que a apreensão da realidade aconteça a partir da totalidade dialética, movido pela práxis humana, movimento em que o sujeito histórico se torne portador dos interesses universais e a totalidade dialética seja a apreensão da realidade concreta. Deste modo, para o autor,

[...] É necessário que ele ponha a prova suas próprias experiências e movimentos do espirito, examinando sua gênese e sua possibilidade de se converter em práxis humana. Se a literatura decadente exclui cada vez mais de sua estética a ação e o enredo, considerados como "anacrônicos", isto ocorre para que possam ser defendidas as tendências da decadência. (LUKÁCS, 2010, p. 82)

Marx aponta para importância do caráter social do homem e da sua tomada de consciência. Partindo da alegação "sou social, porque atuo como homem" (MARX, 1974, p. 10). Percebe-se que tanto o objeto quanto o sujeito são resultados da materialização e da exteriorização das relações sociais com outros homens, a sociedade produz os homens e os homens produzem e reproduzem. O movimento mais geral do ser é determinado "em si" e "para si".

A filosofia da decadência se constitui pela ideologia capitalista e todo o tempo se evade das contradições do sistema capitalista, na tentativa de gerar conformidade, aprimorando as inumanidades do capitalismo. O espírito pequeno-burguês só pode ser intimamente superado por uma verdadeira compreensão dos grandes conflitos e das crises do desenvolvimento social, porém o atual contexto tem mostrado apelações para a interioridade da vida humana, desprezando os conflitos externos.

Apreende-se, então, que o sistema cria e recria condições para se conservar e manter a cultura do consumo e a manutenção do sistema capitalista, sendo todas as funções reprodutivas sociais subordinadas as formas que são criadas $[. .$.$] - das relações de gênero$ 
familiares à produção material, incluindo até mesmo a criação das obras de arte - ao imperativo absoluto da expansão do capital, ou seja, da sua própria expansão e reprodução como um sistema de metabolismo social de mediação (ANTUNES, 2009, p. 23). 


\section{REFERÊNCIAS}

ALVES, Carolina Leocádio. Educação física e formação humana: contribuições para o debate a partir da interlocução com a ontologia do ser social de Gyorgy Lukács. Dissertação (Mestrado em Educação Física) - Universidade de Brasília, Brasília, 2015.

ANDERSON, P. Balanço do neoliberalismo. In: SADER, E.; GENTILI, P. Pósneoliberalismo: as políticas sociais e o Estado democrático. Rio de Janeiro: Paz e Terra, 1995.

ANDES-SN. Relatório Final do $14^{\circ}$ Congresso Nacional do Sindicato dos Docentes das Instituições de Ensino Superior - ANDES Sindicato Nacional. De 14 a 18 de fevereiro de 1995, na cidade de Brasília, Distrito Federal. Disponível em: < http://www.andes.org.br/andes/portal-relatorio-conad-congresso.andes >. Acesso em 21 jan. 2016.

ANTUNES, R. Dimensões da crise e as metamorfoses do mundo do trabalho. Serviço Social \& Sociedade. São Paulo, ano XVII, n.50, Cortez, pp. 78-86, abril 1996.

Adeus ao trabalho: ensaio sobre as metamorfoses e a centralidade do mundo do trabalho. $11^{\circ}$ ed. São Paulo: Cortez, 2006.

Os sentidos do trabalho: ensaio sobre a afirmação e a negação do trabalho. $2^{\circ}$ ed. São Paulo: Boitempo Editorial, 2009.

; ALVES, G. As mutações no mundo do trabalho na era da mundialização do capital. In: Educação e Sociedade, Campinas, vol. 25, n. 87, p. 335-351, maio/ago. 2004.

ÁVILA, A. B. A pós-graduação em Educação Física e as tendências na produção de conhecimento: o debate entre realismo e anti-realismo. Tese (Doutorado em Educação), Centro de Ciências da Educação, Universidade Federal de Santa Catarina, 2008.

BANCO MUNDIAL. La Ensenanza Superior: Ias lecciones derivadas de la experiencia (EI Desarrollo en la práctica). Washington, D.e.: BIRD/Banco Mundial, 1994. Disponível em: < http://firgoa.usc.es/drupal/files/010-1344Sp.pdf >. Acesso em 21 jan. 2016.

BEHRING, E. R. Brasil em contra-reforma: desestruturação do Estado e perda de direitos. $2^{\circ}$ ed. São Paulo: Cortez, 2008.

BRACHT, V. Educação física \& ciência: cenas de um casamento (in) feliz. Ijuí: Unijuí, 1999.

Desafios e dilemas da pós-graduação em educação física. In: RECHIA, S. et al. Dilemas e desafios da Pós-Graduação em educação física. Ijuí: Editora Unijuí, 2015.

BRASIL, Ministério da Educação, Conselho Federal de Educação, Parecer CES/CFE 977/65. Brasília, $1965 . \quad$ Disponível em: < https://www.capes.gov.br/images/stories/download/legislacao/Parecer_CESU_977_1965.pdf >. Acesso em 21 jan. 2016. 
BRASIL, Ministério da Educação, Coordenação de Aperfeiçoamento de Pessoal de Nível Ensino Superior, I PNPG - Plano Nacional de Pós-Graduação. Brasília: CAPES, 1975. Disponível em: < http://www.capes.gov.br/plano-nacional-de-pos-graduacao>. Acesso em 21 jan. 2016.

BRASIL, Ministério da Educação, Coordenação de Aperfeiçoamento de Pessoal de Nível Ensino Superior, II PNPG - Plano Nacional de Pós-Graduação. Brasília: CAPES, 1982. Disponível em: < http://www.capes.gov.br/plano-nacional-de-pos-graduacao>. Acesso em 21 jan. 2016.

BRASIL, Ministério da Educação, Coordenação de Aperfeiçoamento de Pessoal de Nível Ensino Superior, III PNPG - Plano Nacional de Pós-Graduação. Brasília: CAPES, 1986. Disponível em: < http://www.capes.gov.br/plano-nacional-de-pos-graduacao>. Acesso em 21 jan. 2016.

BRASIL, Ministério da Educação, Coordenação de Aperfeiçoamento de Pessoal de Nível Ensino Superior, V PNPG - Plano Nacional de Pós-Graduação. Brasília: CAPES, 2005. Disponível em: < http://www.capes.gov.br/plano-nacional-de-pos-graduacao>. Acesso em 21 jan. 2016.

BRASIL, Ministério da Educação, Coordenação de Aperfeiçoamento de Pessoal de Nível Ensino Superior, VI PNPG - Plano Nacional de Pós-Graduação - V. I. Brasília: CAPES, 2011. Disponível em: < http://www.capes.gov.br/plano-nacional-de-pos-graduacao>. Acesso em 21 jan. 2016.

BRASIL, Ministério da Educação, Coordenação de Aperfeiçoamento de Pessoal de Nível Ensino Superior, VI PNPG - Plano Nacional de Pós-Graduação - V. II. Brasília: CAPES, 2011a. Disponível em: < http://www.capes.gov.br/plano-nacional-de-pos-graduacao >. Acesso em 21 jan. 2016.

BRASIL, Ministério da Educação, Coordenação de Aperfeiçoamento de Pessoal de Nível Ensino Superior, Documento da Área de Educação Física 2004. Brasília: CAPES, 2004. Disponível em: < http://www.capes.gov.br/component/content/article/44-avaliacao/4666educacao-fisica>. Acesso em 21 jan. 2016.

BRASIL, Ministério da Educação, Coordenação de Aperfeiçoamento de Pessoal de Nível Ensino Superior, Documento da Área de Educação Física 2007. Brasília: CAPES, 2007. Disponível em: < http://www.capes.gov.br/component/content/article/44-avaliacao/4666educacao-fisica>. Acesso em 21 jan. 2016.

BRASIL, Ministério da Educação, Coordenação de Aperfeiçoamento de Pessoal de Nível Ensino Superior, Documento da Área de Educação Física 2010. Brasília: CAPES, 2010. Disponível em: < http://www.capes.gov.br/component/content/article/44-avaliacao/4666educacao-fisica>. Acesso em 21 jan. 2016.

BRASIL, Ministério da Educação, Coordenação de Aperfeiçoamento de Pessoal de Nível Ensino Superior, Documento da Área de Educação Física 2013. Brasília: CAPES, 2013. Disponível em: < http://www.capes.gov.br/component/content/article/44-avaliacao/4666educacao-fisica>. Acesso em 21 jan. 2016. 
BRASIL, Ministério da Educação, Coordenação de Aperfeiçoamento de Pessoal de Nível Ensino Superior, Relatório de avaliação trienal 2007-2009. Brasília: CAPES, 2010a. Disponível em: < http://www.capes.gov.br/component/content/article/44-avaliacao/4666educacao-fisica>. Acesso em 21 jan. 2016.

BRASIL, Ministério da Educação, Coordenação de Aperfeiçoamento de Pessoal de Nível Ensino Superior, Relatório de avaliação trienal 2010-2012. Brasília: CAPES, 2013a. Disponível em: < http://www.capes.gov.br/component/content/article/44-avaliacao/4666educacao-fisica >. Acesso em 21 jan. 2016.

CAPES - Coordenação de Aperfeiçoamento Pessoal de Nível Superior (2016). Disponível em: < http://www.capes.gov.br>. Acesso em 01 fev. 2016.

CASTELlANI FILHO, Lino. Educação Física no Brasil: a história que não se conta. $3^{\circ}$ ed. Campinas, SP: Papirus, 1991.

COLETIVO DE AUTORES. Metodologia do ensino da educação física. $2^{\circ}$ ed. São Paulo: Cortez, 2009.

COUTINHO, Carlos Nelson. O Estruturalismo e a Miséria da Razão. São Paulo, SP: Expressão Popular, 2010.

DARIDO, S. C. Educação Física na escola: questões e reflexões. Rio de Janeiro: Guanabara Koogan, 2003.

DELLA FONTE, Sandra Soares. Fundamentos teóricos da pedagogia histórico-crítica. In: A. C. G. MARSIGLIA (Org.), Pedagogia histórico-crítica: 30 anos. Campinas, SP: Autores Associados, 2011, p. 23-39.

EAGLETON, T. De onde vêm os pós-modernistas? In: Wood, E. M. \& Foster, J. B. (orgs.). Em defesa da história: marxismo e pós-modernismo. Rio de Janeiro: Jorge Zahar, pp. 23-32.

EVAngElista, J. E. Crise do marxismo e irracionalismo pós-moderno. São Paulo: Cortez, 1992.

.Teoria social pós-moderna: introdução crítica. Porto Alegre. Sulina, 2007.

Elementos para uma crítica da cultura pós-moderna. Revista Novos Rumos, São Paulo, ano XVI, n. 34, Instituto Astrogildo Pereira, pp. 29-40, 2001.

FERREIRA, A. B. de H. Miniaurélio Século XXI Escolar: o minidicionário da língua portuguesa. $4^{\circ}$ ed. Rio de Janeiro: Editora Nova Fronteira, 2001.

FERREIRA JUNIOR, A.; BITTAR, M. Educação e ideologia tecnocrática na ditadura militar. Caderno Cedes, Campinas, v.28, n. 76, p. 333-355, set/dez.2008. Disponível em <http:// www.cedes.unicamp.br>. Acesso em 01 jun. 2016.

Proletarização e sindicalismo de professores na ditadura militar (19641985). São Paulo, SP: Terras do Sonhar: Edições Pulsar, 2006. 
A ditadura militar e a proletarização de professores. Educação e Sociedade, Campinas, vol. 27, n. 97, p. 1159-1179, set./dez. 2006a. Disponível em <http:// www.cedes.unicamp.br>. Acesso em 01 jun. 2016.

FRIGOTTO, Gaudêncio. O enfoque da dialética materialista histórica da pesquisa educacional. In: FAZENDA, Ivani. (Org.) Metodologia da pesquisa educacional. $6^{\circ}$ ed. São Paulo: Cortez, 2000. p. 69-90.

HÚNGARO, Edson Marcelo. Modernidade e Totalidade - em defesa de uma categoria ontológica. Dissertação (Mestrado em Serviço Social) - Pontifícia Universidade Católica de São Paulo, São Paulo, SP, 2001.

. Trabalho, tempo livre e emancipação humana - os determinantes ontológicos das políticas sociais de lazer. Tese (Doutorado em Educação Física) - Faculdade de Educação Física, Universidade Estadual de Campinas, Campinas, SP, 2008.

. A Educação Física e a tentativa de "deixar de mentir": o projeto de "intenção de ruptura”. In: MEDINA, João Paulo Subirá (Org.). A Educação Física cuida do corpo...e "mente": novas contradições e desafios do século XXI. $25^{\circ}$ ed. ver. ampl. Campinas: Papirus, 2010, p. 135-159.

HÚNGARO, Vitor. Pós-modernidade, revista movimento e a produção de conhecimento na Educação Física. Dissertação (Mestrado em Ciências Sociais) - Pontifícia Universidade Católica de São Paulo, São Paulo, SP, 2012.

HOBSBAWN, E. A Era do Capital (1848-1875). 4º ed. Rio de Janeiro: Paz e Terra, 1988.

A Era dos Extremos: o breve século XX 1914-1991. 20 ed. São Paulo: Companhia das Letras, 1995.

INFOCAPES. Boletim Informativo, Vol. 3, No 1 e 2, Jan/Jun., 1995. Disponível em: < http://www.capes.gov.br/publicacoes/publicacoes-antigas >. Acesso em 04 jan. 2016.

INFOCAPES. Boletim Informativo, Vol. 3, No 1 e 2, Jan/Jun., 1998. Disponível em: < http://www.capes.gov.br/publicacoes/publicacoes-antigas >. Acesso em 04 jan. 2016.

KUENZER, A. Z.; MORAES, M. C. M. de. Temas e tramas na pós-graduação em educação. Educ. Soc., set./dez. 2005, vol.26, n.93, p.1341-1362.

LARA, R. Notas lukacsianas sobre a decadência ideológica da burguesia. In: Revista Katálysis, Florianópolis, v. 16, n. 1, p. 91-100, jan./jun. 2013. Disponível em < https://periodicos.ufsc.br/index.php/katalysis>. Acesso em 04 jan. 2016.

LAZZAROTTI FILHO, Ari; SILVA, Ana Márcia; NASCIMENTO, Juarez Vieira do; MASCARENHAS, Fernando. Modus operandi da produção científica da Educação Física: Uma análise das revistas e suas veiculações. Revista da Educação Física/UEM (Online), v. 23, p. 1-14, 2012. Disponível em http://www.periodicos.uem.br/ojs/index.php/RevEducFis/article/view/12551/9325>. Acesso em 01 jun. 2016. 
LUKÁCS, H. J. Marx e o problema da decadência ideológica. In: Marxismo e teoria da literatura. $2^{\circ}$ ed. São Paulo: Expressão Popular, 2010, p. 51-103.

As bases ontológicas do pensamento e da atividade do homem. Temas de Ciências Humanas, São Paulo, n. 4, 1978. p. 01-20.

Os princípios ontológicos fundamentais de Marx. Trad. de Carlos Nelson Coutinho. São Paulo: Ciências Humanas, 1979.

MANDEL, E. O capitalismo tardio. Trad. de Carlos Eduardo Silveira Matos. São Paulo: Abril Cultural, 1982. (Os Economistas)

MANOEL, Edison de Jesus. Breve reflexão sobre a Pós-Graduação na Grande Área da Saúde: Um conto, um mito e um filme. Cadernos de Terapia Ocupacional da UFSCar, v. 17, p. 87-91, 2009. Disponível em: < http://www.cadernosdeterapiaocupacional.ufscar.br/index.php/cadernos/article/view/277 >. Acesso em 07 fev. de 2016.

MARX, Karl. Terceiro manuscrito. In: Manuscritos econômico-filosóficos e outros escritos. São Paulo: Abril Cultural, 1974. p. 03-48. (Os Pensadores).

. Trabalho assalariado e capital. Rio de Janeiro: Global, 1985.

O dezoito Brumário de Louis Bonaparte. São Paulo: Centauro, 2003.

. Sobre a questão judaica. São Paulo: Boitempo, 2010.

. Uma Introdução para a Crítica da Economia Política. Disponível em: < http://www.histedbr.fe.unicamp.br/acer_fontes/acer_marx/tme_15.pdf $>$. Acesso em $07 \mathrm{fev}$. de 2016.

; ENGELS, F. Manifesto do partido comunista. Prólogo de José Paulo Netto. São Paulo: Cortez, 1998.

; ENGELS, F. A ideologia alemã (Feurbach). 11º ed. São Paulo: Hucitec, 1999.

MOLINA, R. K.; MOLINA NETO, V. Considerações sobre a produção do conhecimento em educação física/ciências do esporte. In: RECHIA, S. et al. Dilemas e desafios da PósGraduação em educação física. Ijuí: Editora Unijuí, 2015.

MORAES, M. C. M. Avaliação na pós-graduação brasileira: novos paradigmas, antigas controvérsias. In: BIANCHETTI, L. MACHADO, A. M. N.(org). A bússola do escrever: desafios e estratégias na orientação e escritas de teses e dissertações. $2^{\circ}$ ed. São Paulo: Cortez da UFSC, 2006, p. 187-214.

NANDA, M. Contra a destruição/desconstrução da ciência: histórias cautelares do terceiro mundo. In: Wood, E. M. \& Foster, J. B. (orgs.). Em defesa da história: marxismo e pósmodernismo. Rio de Janeiro: Jorge Zahar, pp. 84-106. 
NETTO, J. P.. Elementos para uma crítica do Manifesto Comunista. In: MARX, K.; ENGELS, F. Manifesto do partido comunista. São Paulo: Cortez, 1998.

. Posfácio. In: COUTINHO, C. N. Estruturalismo e a miséria da razão. $2^{\circ}$ ed.

São Paulo: Expressão Popular, 2010, pp. 233-286.

; BRAZ, M. Economia Política: uma introdução crítica. $7^{\circ}$ ed. São Paulo: Cortez, 2011.

PATRIARCA, Amanda Corrêa. A decadência ideológica contemporânea e a educação física: as incidências sobre a pós-graduação. Dissertação (Mestrado em Educação Física) Universidade de Brasília, Brasília, 2012.

PINASSI, M. O. Da miséria ideológica à crise do capital: uma reconciliação histórica. São Paulo: Boitempo, 2009. (Coleção Mundo do Trabalho).

RECHIA, S. et al. Dilemas e desafios da Pós-Graduação em educação física. Ijuí: Editora Unijuí, 2015.

RODRIGUES, Maví. Michel Focault sem espelhos: um pensador proto pós-moderno. Tese (Doutorado em Serviço Social) - Faculdade de Serviço Social, Universidade Federal do Rio de Janeiro, Rio de Janeiro, RJ, 2006.

RODRIGUES, Luiz Oswaldo Carneiro. Publicar mais, ou melhor? O tamanduá olímpico. Revista Brasileira de Ciências do Esporte, v. 29, p. 35-48, 2007. Disponível em: < http://www.scielo.br/pdf/pusp/v22n2/aop1611.pdf >. Acesso em 07 fev. de 2016.

SACARDO, Michele Silva. Estudo bibliométrico e epistemológico da produção científica em Educação Física na Região Centro-Oeste do Brasil. Tese (Doutorado em Educação e Ciências Humanas) - Faculdade de Educação, Universidade Federal de São Carlos, São Carlos, SP, 2012.

SÁNCHEZ GAMBOA, S. Epistemologia da Educação Física: as inter-relações necessárias. $2^{\circ}$ ed. rev. e amp. Maceió: EDUFAL, 2010.

; GAMBOA, M. F. C. A quantidade - VS - qualidade na produção de conhecimento em educação física: os desafios de uma experiência concreta. In: RECHIA, S. et al. Dilemas e desafios da Pós-Graduação em educação física. Ijuí: Editora Unijuí, 2015.

. O debate da pós-modernidade: as teorias do conhecimento em jogo. Filosofia e Educação (Online) Revista Digital do Paideia, vol. 2, n. 2, Out. 2010-Março 2011, p.74 - 98. Disponível em < http://ojs.fe.unicamp.br/ged/rfe/article/view/2170>. Acesso em 01 jun. 2016.

SAVIANI, D. História das idéias pedagógicas no Brasil. $2^{\circ}$ ed. rev. e ampl. Campinas-SP: Autores Associados, 2008.

O legado educacional do regime militar. Caderno Cedes, Campinas, vol. 28, n.76, p. 291-312, set/dez. 2008a. Disponível em <http:// www.cedes.unicamp.br>. Acesso em 01 jun. 2016. 
SCHAFF, Adam. O marxismo e o indivíduo. Tradução de Heidrun Mendes da Silva. Rio de Janeiro: Civilização Brasileira, 1967.

SGUISSARDI, V. Diferenciação e Diversificação: marcas das políticas de educação superior no final do século. In: SGUISSARDI, V. (Org.). Educação Superior: velhos e novos desafios. São Paulo: Xamã, 2000. p. 47-62.

SILVA, Régis Henrique dos Reis. Tendências teórico-filosóficas das teses em educação especial desenvolvidas nos cursos de doutorado em educação e educação física do estado de São Paulo (1985-2009). Tese (Doutorado em Educação) - Faculdade de Educação, Universidade Estadual de Campinas, Campinas, SP, 2013.

SOARES, Carmem Lúcia. Educação Física: raízes européias e Brasil. $3^{\circ}$ ed. Campinas, SP: Autores Associados, 2004.

STIGGER, M. P.; SILVEIRA, R. da; MYSKIW, M. O processo de avaliação da pósgraduação em educação física e ciências do esporte no Brasil e algumas das suas repercussões cotidianas. In: RECHIA, S. et al. Dilemas e desafios da Pós-Graduação em educação física. Ijuí: Editora Unijuí, 2015.

WOOD, E. M. e FOSTER, J. B. Em defesa da história: marxismo e pós-modernismo. Rio de Janeiro: Jorge Zahar, 1999. 